JEAN-GEORGES KASTNER'S TRAITÉ GÉNÉRAL D'INSTRUMENTATION:

\title{
A TRANSLATION AND COMMENTARY
}

Patricia Jovanna Woodward, B.M.

Thesis Prepared for the Degree of

MASTER OF MUSIC

UNIVERSITY OF NORTH TEXAS

May 2003

\section{APPROVED:}

John Michael Cooper, Major Professor

Lyle Nordstrom, Committee Member

Deanna Bush, Committee Member and Coordinator of the program in Music History

Lester Brothers, Chair of the Division of Music History, Theory, and Ethnomusicology

James C. Scott, Dean of the College of Music

C. Neal Tate, Dean of the Robert B. Toulouse School of Graduate Studies 
Woodward, Patricia Jovanna, Jean-Georges Kastner's Traité général

d'instrumentation: A Translation and Commentary. Master of Music (Musicology), May 2003, 317 pp., references, 26 titles.

Georges Kastner's (born Strasbourg 9 March 1810; died Paris 19 December 1867) Traité général d'instrumentation (1837), an important contribution to instrumentation study, is often overlooked because of its chronological proximity to Berlioz's Grand traité d'instrumentation (1843). Kastner's complete and concise treatise discusses the standard orchestral instruments and several obscure and ancient instruments. Intended principally for young composers, it provides the most detailed descriptions of the standard wind instruments of his day and discusses recent developments like the ophicleide and valved brass instruments. After the publication of the Traité, Kastner released a supplement including Aldophe Sax's newest innovations, entitled Cours d'instrumentation, which included musical examples of principals discussed in the Traité. Both the Traité and the Cours were accepted by the Academy and adopted by the Paris Conservatoire. 
Copyright 2003

by

Patricia Jovanna Woodward 


\section{TABLE OF CONTENTS}

Page

Part I

INTRODUCTION: KASTNER AND THE ART OF INSTRUMENTATION 1

Kastner's Life and Times

Instrumentation Treatises before Kastner

After the Treatise

The Treatise

Comparing Kastner with Berlioz

Conclusion

A Note on the Translation and Editorial Procedures

Part II

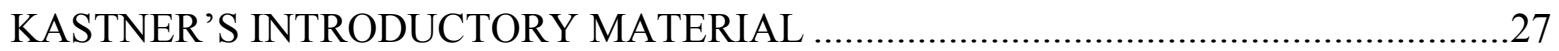

Approval by the Academie

Foreword

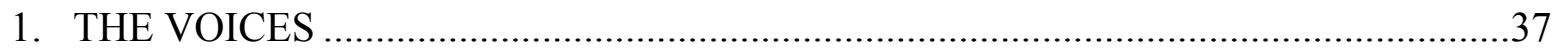

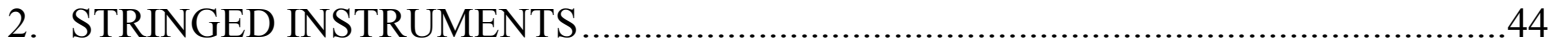

Violin

Viola

Viola da Gamba

Viola Bastarda

Trumpet-Marine

Viola Pomposa

Viola d'amore

Viola da Spalla

Viola di Bardone (or Baritone)

Violoncello

Double Bass (Counter-Violin)

Guitar

Decacord

Lute

Theorbo

Mandore 
Mandoline

Cittern

Harp

Double-Action Harp

Gussel or Gusli

Ditale Harp

Aeolian Harp

3. KEYBOARD INSTRUMENT

Dulcimer or Manicorde

Harpsichord

Forte Piano (or Piano Forte, Grand Piano)

Organ

Orchestrion

Barrel Organ (Portative Organ)

Expressive Organ

Accordian

Aeolodicon

Glass Harmonica

Poikilorgan

4. WIND INSTRUMENTS.

Flute

Tierce Flute

Octave Piccolo (Piccolo)

Flageolet

Oboe

Cornemuse (Musette)

English Horn

Bassoon

Contrabassoon

Clarinet

Bassett Horn (or Muted Clarinet)

Chalumeau

Alp Horn

Serpent

Horn

Hunting Horn

Valved Horn

Trumpet

Cornet

Valved Trumpet

Valved Cornet

Keyed Trumpet 
Signal Horn

Trombone

Valved Trombone

Ophicleide

Apollonian Lyre

Jaw-Harp

5. PERCUSSION INSTRUMENTS

Timpani

Tambourine

Tenor Drum

Side Drum

Bass Drum

Triangle

Cymbals

Turkish Crescent

Tam-Tam

Belfry

Bell

Chime

Castanets

Systrum

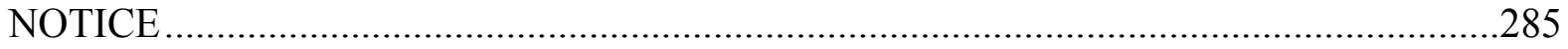

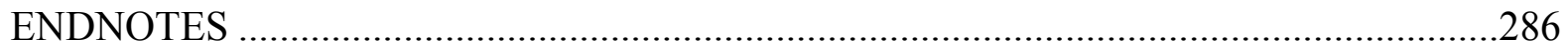

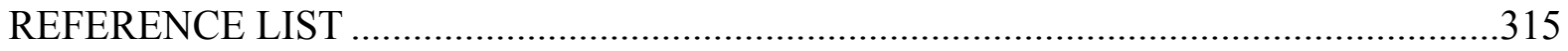




\section{INTRODUCTION}

\section{KASTNER AND THE ART OF INSTRUMENTATION}

First published in 1837, Jean-Georges Kastner's Traité général d'instrumentation has been eclipsed by Berlioz's 1843 treatise on the same subject. Although Berlioz's work in the seemingly new field of orchestration is widely acknowledged, there are actually several treatises which deserve a more thorough inspection. Georges Kastner's innovative and sizable digest deserves a much more thorough inspection. This study will offer general information concerning Kastner's life and works and their significance to his contemporaries, and will summarize important contemporary developments in the study of instrumentation and orchestration. It will also explore some significant similarities and differences between Kastner's and Berlioz's treatises and place Kastner's work within the historical context of developments in orchestration.

\section{Kastner's Life and Times}

Although most strongly remembered for his musicological writings, Georges Kastner's compositional output is significant in both its size and breadth. He composed in a variety of genres, including operas, choral works with orchestra and with piano, songs for men's chorus, solo vocal songs, symphonies, overtures, serenades for wind band, marches for military band, and chamber music. In addition to writing within these well-established genres, he also invented the livre-partition, a lengthy essay followed by an original piece of music. Arhives of his compositions and theoretical writings have been acquired and housed both in Strasbourg, France as well as in the Paris Conservatoire. ${ }^{1}$ 
Jean-Georges Kastner was born on March 9, 1810 (or in 1811) ${ }^{2}$ in Strasbourg, France. He demonstrated a high level of musical aptitude from an early age and began studying the piano when he was six years old. By the age of ten he was playing the church organ on feast days in a town close to Strasbourg. His parents, noticing his serious temperament and natural inclination toward academia, urged him to take up a career in theology despite his musical talents. He respected his family's wishes by pursuing a degree in theology but did not, according to Fétis, "give up his studies for the art which was for him the object of a true passion." Kastner began writing music by age sixteen and had already written his first full-length opera, La Prise de Missolonghi, ${ }^{4}$ before he was twenty.

In addition to his piano studies, Kastner began to explore the workings of other orchestral instruments. He studied some of them on his own and learned about others by consulting with various performing musicians. Certain instruments were rather difficult for Kastner to learn, whereas he developed a high level of proficiency on others. ${ }^{5}$ It was through this experience that he first developed the idea of writing an instrumentation manual, an idea that would come to fruition a decade later with the publication of his Traité général d'instrumentation.

While completing his education, Kastner wrote three symphonies, five overtures, ten serenades for wind band, a piano concerto, numerous marches, choruses, and piano waltzes. ${ }^{6} \mathrm{He}$ was also the bandmaster of the Strasbourg National Guard, which earned him a reputation for his outstanding conducting abilities. ${ }^{7}$ After graduating with a degree in arts in 1829 , Kastner studied instrumentation and composition with Maurer and counterpoint and fugue with J. C. Böhner in Strasbourg.

Kastner wrote grand opera as well as opéra comique in both French and German. Kastner composed La Mort d'Oscar (1834), a grand opera, and Le Sarrasin (1834), an opéra 
comique, before he achieved major success with the premiere of his opera Die Königin der Sarmaten. Although Die Königin der Sarmaten was written in 1833, it was not premiered until 1835, and it received such positive reviews that the town council was prompted to grant Kastner a stipend to study at the Paris Conservatoire. ${ }^{8}$

At the Paris Conservatoire Kastner studied counterpoint and fugue with Antoine Reicha (1770-1836) and composition with Henri Berton (1784-1832), both of whom were encouraging of his artistic endeavors outside of the classroom. He began to write method books for voice, piano, violin, flute, flageolet, clarinet, horn, cello, ophicleide, trombone, oboe, and the valve cornet. He finally had the opportunity to combine several of these practical works, producing the Traité général d'Instrumentation in 1835 (published in 1837), ${ }^{9}$ which he submitted to the Académie des beaux-arts de l'Institut for review. The work received official approval and a favorable report by the Academie. The treatise was then adopted for use in the curriculum of the Paris Conservatoire. This was the first work of its kind to cover the standard orchestral instruments and certainly influenced Berlioz's own orchestration treatise (1843). ${ }^{10}$

In 1836, after he completed his Traité, Kastner published a second book entitled Traité de l'instrumentation considérée sous les rapports poétiques et philosophiques, also published under the title Cours d'instrumentation. ${ }^{11}$ This work, specifically intended for use by young composers, was dedicated to Henri Berton. It was approved by the Academie and used by the Paris Conservatoire in composition classes. The Cours picked up where the Traité left off, following through on the concepts laid out in the earlier study and demonstrating them with musical examples from the standard literature. These examples are taken from the works of composers whom Kastner held in high regard, including Beethoven, Berlioz, Berton, Cherubini, Gluck, Meyerbeer, and Mozart. 
The third of Kastner's writings to be approved by the Academie and subsequently adopted by the Paris Conservatoire was his Grammaire musicale, dedicated to Giacomo Meyerbeer. This treatise was conceived as an elementary system of music focusing on the "various parts which contribute to the realization of the idea in composition."12 Designed for use by amateurs and by professionals alike, this treatise was divided into three main sections (melody, rhythm, and harmony), and also included a brief overview of the voices and instruments. Shortly thereafter, Kastner published a Tableaux analytiques des principes élémentaires de la musique and a Tableaux analytiques de l'harmonie which provided elementary and practical applications of the principles outlined in his Grammaire musicale. ${ }^{13}$

In addition to his academic writings, Kastner maintained his compositional vitality. In 1839, he wrote a German opera entitled Beatrice which was well received by its foreign audience. Following Beatrice was the two-act French opera La Maschera. Because of strained relations between the librettist and the director of the Opéra-Comique, the composition of $L a$ Maschera was a taxing process. This difficult experience ultimately resulted in a successful debut on June 17,1841 . The debut was so well received that an inscription commemorating its success was added to the score. ${ }^{14}$

Kastner wrote a series of dramatic scenes and romances in 1838 that were quite pleasing to French audiences. These compositions included the Suite de cantiques arrangés à trois voix, a collection of three-part choral works written for the Pariser Gemeinde Augsburgischen Bekenntnisses. ${ }^{15}$ Along with these works were also the Collection populaire de chant, Le nègre, L'orphelin, Le chasseur de chamois, and several other songs and dramatic scenes. These compositions were well received, and the music critic François-Henri-Joseph Castil-Blaze (17841857) wrote of the dramatic scenes that "the composer shows an undeniable dramatic talent; the 
motifs for songs are always analogous to the text, and return the situation exactly."16 The popularity of these vocal compositions is punctuated by Castil-Blaze's final request that "Kastner not to make us await too long for the continuation of his melodies and of his dramatic scenes."17

In 1839, Kastner met Adolphe Sax (1814-1894) during Sax’s first trip to Paris. Sax’s improvements to the bass clarinet immediately captured Kastner's attention, and the two forged a lifelong friendship. In 1842, when Sax returned to Paris, he brought his newly-perfected invention, the saxophone. This new invention was heralded by creative Parisian musicians and even caught the attention of Berlioz. Berlioz wrote an article about the new instrument and its inventor, entitled "Le Saxophon” which was featured in the Journal de Débats on June 21, 1842. ${ }^{18}$ Kastner said that this new instrument was "the result of sudden inspiration"19 and in his Manuel général de musique militaire, he goes on to describe the saxophone as an instrument with an entirely new sound - powerful, far-reaching, expressive and beautiful. With its unique tonal quality, it offers the best imaginable link between the very high voices of the orchestra and the very weak ones or those with a very uneven timbre ... Uniting strength and charm, it does not drown out the one kind and cannot be drowned out by the other - it is a perfect instrument. ${ }^{20}$

Kastner was the first to use the saxophone in an original work with his 1843 opera Le dernier roi de Juda. The opera includes a part for the saxophone in C and Sax himself played this part at the opera's premiere. Fétis recorded the reaction of an 1844 music critic as follows: "one of the best music-critics of the time wrote after hearing, 'The composition of Mr. Kastner joins together an abundance of ideas to the classical purity, with knowledge that benefits from musical thought, without reducing it to the exiguous form of an imitation brought back without delay, so as to create trouble by monotony." 21 Following Kastner's innovative use of saxophone in opera, composers such as Limnander, Thomas, Saint-Saëns, Meyerbeer, Bizet, and d'Indy used it in their operatic compositions. ${ }^{22}$ 
Because the saxophone had only recently been invented there was a lack of skilled teachers, so students who wished to learn the instrument were forced to rely on mainly on tutors and written articles about the saxophone to aide them in their endeavor. Kastner's writings were some of the earliest resources in this regard. In 1844, Kastner included a lengthy article on the instrument in his Supplement au Traité général d'Instrumentation. This article discusses how a composer should properly write music for the saxophone and is also a significant resource for iconographical depictions of the saxophone.

Kastner's Méthode complete et raisonée de Saxophone, written in 1846, was the first complete saxophone tutor. It is a significant resource not only as a didactic tool, but also because it included a lengthy passage about the evolution of the saxophone and writings about an entire family of saxophones, including those that did not yet exist. ${ }^{23}$ The Méthode included both Kastner's Sextour, written in approximately 1844, and the Variations Faciles et Brillantes pour Saxophone alto en Mi b, which are the two earliest known pieces of music for saxophone. In addition to these two pieces, he also included 14 pages of melodies that he adapted for the saxophone by composers such as Cimarosa, Gretry, Haydn, Mehul, Mozart, and Rossini.

Kastner's next major work, Manuel général de musique militaire à l'usage des armées françaises, ${ }^{24}$ was published as four books in one large volume by Didot in 1848. At 410 pages in length, this work contains a great deal of historical information, presented as lithographs of instruments, musical examples, and narrative. This source has been frequently consulted and cited for research on the subject of bugle calls and timpani music.

In 1852, Kastner published the first of a series of new works that combined his research endeavors with his compositional skills in a new genre was called the livre-partition. His composition, Les Danses des morts; dissertations et recherches historiques, philosophiques, 
littéraires et musicales sur les divers monuments de ce genre qui existent tant en France qu'il l'étranger; accompagnées de la Danse macabre, grande ronde vocale et instrumentale, paroles d'Édouard Thierry, musique de Georges Kastner, gave an historical chronology of the dance of death from the middle ages to the nineteenth century. This 310-page work contained lithographs of the instruments used in the dance of death and offered an explanation of the instruments used in the middle ages. ${ }^{25}$ The text was divided into three sections: the idea of death (texts of the dance of death, symbolization, personification and representation of dead); images and tables of the dances of deaths; and the origin and statistics on the French and foreign dance of death. A review of this work in the Revue et Gazette musicale declared that it was a success:

As for the material executed in the beautiful volume announced in this article, it does leave anything to be desired. We thus think that the book entitled Les Danses des Morts will find many readers among the men educated in all the classes: historians, literary men, archeologists, musicians, painters, and bibliophiles, and that, with information so new and so useful that he provides on several points, it will fill more than one gap in the field of sciences, the letters, and arts. ${ }^{26}$

Kastner went on to write five more livre-partitiones on subjects ranging from the cries of Paris, songs of the French army, and the Aeolian harp.

Kastner's last significant production was a comprehensive reference work published in 1862, entitled Parémiologie musicale de la langue française, ou explication des proverbes, locutions proverbiales, mots figures qui tirent leur origine de la musique, accompagnée de recherches sur un grand nombre d'expressions du même genre empruntées aux langues étrangers, et suivie de la Saint-Julien des ménétriers, symphonie cantate à grand orchestre, avec solos et chœurs. In his biography of Kastner, Fétis described the concept of this book as truly original. Fétis also credited Kastner with a vast knowledge of language and proverbs from many European countries. ${ }^{27}$ 
Kastner's lifelong goal of completing an encyclopedia of music was never fulfilled. Although he had completed a great deal of research for this enormous project and he had published many articles on the subjects intended for use in the encyclopedia, he died before the encyclopedia could be completed. An unsigned editorial that appeared in the Revue et Gazette musicale on December 22, 1867 read, "We can hardly express at this time that which has created all this loss, as painful as it is unexpected, and which will be highly felt in the musical world, where our friend occupied a elevated place, conquered by his science and his tireless zeal for art... Today we are limited to pay him the tribute of our quite sincere regrets, which are shared by all those who knew him., 28

Instrumentation Treatises Before Kastner

Treatises prior the nineteenth century most often examine instruments from the perspective of performance practice. These types of writings can be traced back to works such as Sebastian Virdung's Musica getutscht (1511), ${ }^{29}$ and are primarily concerned with the physical aspects, performance and pedagogy of instruments. ${ }^{30}$ In addition, Virdung's Musica getutscht contains a wealth of iconographical depictions of instruments, keyboard and lute tablature, fingering charts, and visual aides to performance of the instruments. Virdung presents his text in a dialectical format, classifying the instruments in organalogical categories, and he is one of the earliest writers on the subject to use the vernacular language. Other treatises from this time include Agricola's Musical instrumentalis deudsch (1528), Praetorius's Syntagma musicum (1619), Trichet's Traité des instruments de musique, and Mersenne's Harmonie universelle (1636). The intended audience for these treatises was the "music lover and connoisseur." 
Mattheson's Das neu-eröffnete Orchester (1713) gives instruction on the art of orchestration by examining the instruments that were in use contemporary to him. This text focuses more on the characteristics and use of instruments in compositions as opposed to the technique required to play the instruments. ${ }^{32}$ It also discusses issues of contemporary musical instruction but does not devote space to repeating old rules of theory. ${ }^{33}$

During the eighteenth century a large number of instrument tutors were published. Though they were primarily intended for self-instruction on the art of performing, they were likely also read by composers who needed the information contained in such volumes for their craft as well. ${ }^{34}$ The works of Joseph Majer (1689-1768) draw upon materials from Mattheson and other contemporary German writers on music. Majer's monograph, Museum musicum theoretico practicum (1732) is a self-tutor on music notation and playing many instruments. The Museum includes fingering and position charts for several instruments ${ }^{35}$ and one of the earliest known printed ranges for the clarinet. ${ }^{36}$

Instrumental instruction manuals in late eighteenth-century France include JeanBenjamin de La Borde's Essai sur la musique ancienne et moderne (1780) and the musical discussions in Diderot's Encyclopédie (1776). The Essai sur la musique ancienne et moderne was a collection of essays that La Borde wrote while traveling through France, Switzerland, and Italy. Not limited to the topic of instrumentation, its goal was to "describe the social context in which music is performed. ${ }^{, 37}$ Unfortunately, the four volume work lacks a strict organizational structure, which made it difficult for composers to use it effectively. La Borde's Essai and Diderot's Encyclopédie were intended for the performer and were significant resources for French composers. 
Due to the rising popularity of the clarinet and horn in an orchestral setting, composers found themselves with new timbral possibilities. Valentin Roeser's Essai d'Instruction A l'usage de ceux qui Composent pour la Clarinette et le Cor, Avec des Remarques sur l'Harmonie et des Exemples à deux Clarinettes, deux Cros et deux Bassons (1764) addressed the technical issues and the identifying characteristics of the clarinet and horn, and is considered to be the first true orchestration treatise. ${ }^{38}$ Roeser was born in Germany, but moved to France and played clarinet in a Parisian orchestra. He was most highly regarded for his pedagogy and composition. Roeser's Essai addresses compositional techniques for the clarinet and horn, including range, transposition, and tonguing. The volume concludes with musical examples written for clarinet, horn, and bassoon. The Essai was the only text of its kind, until the publication of Diapason general de touts les instruments à vent (1772) by Louis Joseph Francoeur.

Designated Francoeur Neveu, Louis Joseph Francoeur was the son of Louis Francoeur, violinist for the Paris Opera Orchestra and nephew of the opera director François Francoeur. His Diapason, written in eight chapters covering the flute, oboe, clarinet, horn, bassoon, trumpet, serpent, and human voice, was based in part on Roeser's Essai d'Instruction. ${ }^{39}$ Like Roeser, Francoeur addresses the composer directly in his text. ${ }^{40}$ In addition to the issues Roeser had addressed, Francoeur's treatise discusses the quality of sound and characteristics of the instruments. Because of its systematic treatment of the instruments and its clear and thorough explanation of the various sizes and transpositions of the clarinet, ${ }^{41}$ it was the most influential treatise through the turn of the century and retained its status as one of the most important works of its time.

Alexandre Choron's Traité general des voix et des instruments d'orchestre, et principalement des instruments à vent, à l'usage des compositeurs, par J. L. Francoeur, nouvelle 
édition, revue et augmentée des instruments modernes, par M. Choron (1813) was largely based on the Diapason. The treatise assumes that composers were most familiar with the stringed instrumets; therefore it focuses on the winds, including discussion of range, intonation, the keys best suited to each instrument, trills, and difficulties in phrasing. ${ }^{42}$ The treatise includes a brief summary of the stringed instruments and smaller sections on the keyboard instruments and voices. Choron's expansion of the Diapason incorporates all orchestral instruments, thereby making it the earliest stand-alone textbook on instrumentation. ${ }^{43}$

The most immediate French predecessor to Kastner's treatise was Gioseffo Catrufo's Traité des voix et des instruments à cordes, à vent, et à percussion, ouvrage à l'usage des personnes qui veulent écrire la partition et arranger des morceaux en harmonie (1832). Catrufo was trained as a singer and earned a positive reputation for his opera compositions. Italian by birth, Catrufo immigrated to France and worked in the Parisian theatre. His treatise attracted little attention when it appeared in 1832; however, it is noteworthy because it discussed the double-action harp and it was the first textbook to include a discussion on the ophicleide.

Kastner stated that he was encouraged to complete his Traité by his teachers at the Conservatoire, Henri Berton and Antoine Reicha. Earlier, Reicha had written two composition treatises, the Cours de composition musicale, ou Traité complet et raisonné d'harmonie pratique (1816-18) and the Traité de haute composition musicale (1824-26). These treatises included discussions on the uses of instruments and voices in compositions. The Cours was adopted by the Conservatoire and Reicha used it in his teaching during the time that Kastner was enrolled as a student. The treatise's main subject matter was that of harmony, analysis, and orchestration. Reicha is recognized for developing an entire system of French analytical terms comparable to those used by Koch in Germany. ${ }^{44}$ Though this book is not solely devoted to orchestration, it did 
affect contemporary thought on the subject. Reicha's interpretation of the orchestra functioning as a "large instrument on which the composer plays" "45 was strikingly similar to Berlioz's own perception of the orchestra.

After the Treatise

Ferdinand Gaßner, an Austrian composer and writer on music, published a little known treatise in 1838. His Partiturkenntnis, ein Leitfaden zum Selbstunterrichte für angehende Tonsetzer oder solche, welche Arrangiren, Partiturlesen lernen oder sich zu Dirigenten von Orchestern oder Militärmusik bilden wollen documented individual instruments, grouped by family, and addressed questions of range, tonal variation, flexibility, and character. ${ }^{46}$ The text was coupled with musical examples by Boieldieu, Meyerbeer, Mozart, Rossini, Winter, and others.

Françios Auguste Gevaert's Traité général d'instrumentation (1863) was heralded as the first important example of an orchestration textbook in French following Berlioz's. ${ }^{47}$ His Nouveau traité d'instrumentation (1885) was a reworking of Gevaert's 1863 Traité. It was so successful that it was declared "a monument of universal knowledge" German (by Reimann), Russian (by Tchaikovsky), English, and Portugese.

When he published Instrumentation in 1876, Ebenezer Prout was the first British music theorist to write extensively on the subject. His theoretical works continued to remain popular until well into the twentieth century. ${ }^{49}$ Instrumentation is a modestly sized handbook most useful for the student of orchestration or the young composer. His introduction mentions a few of what he calls "the many excellent treatises," 
Gevaert, and Lobe. Prout regarded both Gevaert's and Lobe's treatises as the most excellent of the sources.

Prout' treatise is organized into chapters based on groupings of instruments in practice rather than by an organological classification. Groupings such as the stringed orchestra; individual stringed instruments; oboes, bassoons, and horns; and strings, woodwinds, and horns place greater importance on instrumental combinations than on the individual characterstics of these instruments. One striking bit of carryover from Kastner and Berlioz is the discussion on the "third flute in E b." Prout restates Berlioz's clarification of the sounding pitch of this flute in comparison to the written pitch, and reiterates that the flute is sometimes incorrectly called the "third flute in F" ${ }^{51}$ A notable similarity between Kastner's Cours d'instrumentation and Prout's Instrumentation is the choice of musical examples, many of which are by the same composers.

\section{The Treatise}

At the time of the publication of Kastner's Traité, the French musical community had recognized a need for a comprehensive treatise on the instruments. The Gazette musicale was publishing a series of articles on the instruments and many writers on music mentioned the void in this area of musical study. Joseph Mainzer wrote a series of articles for the Gazette musicale, in which he outlined the importance of this area of musical study and highlighted composers who had begun to explore it. Mainzer even went as far as to claim that if Kastner did not take up the subject, that Mainzer himself would complete his own comprehensive treatise on the matter. ${ }^{52}$

Although it is unknown whether or not Kastner was aware of Mainzer's challenge, Kastner did take up the subject matter. In the introduction to his treatise, Kastner states that it 
"relates to the art of orchestral instrumentation in particular - that is, the manner most suitable for each instrument's use, and the good or bad effect which each instrument produces in a given circumstance. ${ }^{, 53}$ The treatise is divided into five chapters: the voices, strings, keyboards, winds, and percussion. Each of the instrumental chapters is organized into smaller units; the strings are divided into bowed and plucked, the keyboards into stringed and wind-blown, and the winds into woodwinds and brass. The work includes a few ancient instruments (such as the monochord and the Appolynian lyre) in addition to the standard orchestral instruments. However, there is no extensive discussion of such instruments since the stated goal of the text was to create a concise treatise that would be accessible to young composers.

The opening chapter covers the human voice and is the shortest chapter in the text. It provides an introduction to the types of female and male voices and vocal ranges for choral use. It also includes advice on composing for choruses of mixed singers, or men or women alone. The chapter concludes with a lengthy resource list of solfege methods and singing methods.

The second chapter covers the stringed instruments. The first instrument in this chapter is the violin, and Kastner uses it to explain techniques that are applicable to all of the bowed instruments, such as double-stops using two, three, and four notes, common cadential patterns, and effects. The effects discussed are the mute, pizzicato, ponticello, harmonics, saccade, vibrato, staccato, martelé, and détaché. The description of these effects is applicable to all of the bowed instruments, thereby eliminating the need for further discussion of these techniques. The article on each stringed instrument following the violin covers tunings, range, and techniques that are commonly used in orchestral playing. Some of the less common bowed string instruments that Kastner includes are the viola da gamba, viola bastarda, trumpet marine, viola pomposa, viola d'amour, viola d'spala, and viola bardone. 
The section on plucked string instruments opens with the guitar. This article covers range, tunings, fingering, and advice on how to write naturally for the guitar. Kastner noted that many young composers are not familiar with the guitar, so he included a table of cadences in several major and minor keys. Kastner wrote that young composers would find this most helpful because it takes in consideration the fingerings required to play each of the chords. Other plucked string instruments in the guitar family that are included in this chapter are the decachord, lute, theorbo, mandore, mandolin, and sistre. The article on the lute includes an explanation of the complex tunings and information on how to read lute tablature.

Instruments of the harp family are covered in the final section of the second chapter; these instruments include the harp, harp in E b, double-action harp, gussel or gusli, harp ditale, and the Aeolian harp. In addition to the solo and orchestral ranges, topics in the harp family include an explanation of how to use the pedals with examples in several keys, what staves to use when writing for the harp, and things that should be avoided in writing for the harp. The article on the recently-invented double-action harp includes an explanation of the advantages of the double-action harp over the traditional harp and the harp in $\mathrm{E} b$.

The keyboard instruments, which are divided into the stringed and wind-blown, are the subject of Chapter Three. The dulcimer is the first instrument discussed in this chapter, and is noted for its use in village dance orchestras. There are short articles dedicated to both the harpsichord and the piano. The information given on these instruments is very brief because Kastner thought that much was already known about these common instruments. He did, however, include an extensive list of methods for the piano for any young composer who would desire further information. 
Kastner describes the organ as being the "most complete, interesting and perfect instrument" ${ }^{\circ 4}$ because of its ability to join together all other instruments with its many timbres. He dedicates quite a bit of space to the explanation of the organ, noting that it takes a talented artist to play such a complex instrument (one on which he was known for his masterful abilities in his youth). He gives a thorough account of tones produced within each registration stop as well as covering the chords produced by using the mixed registration stops. At the conclusion of the organ article is a list of authors on the subjects of organ construction and organ performance. Other instruments covered in the wind-blown keyboard grouping are the orchestrion, barrel or portative organ, expressive organ, accordion, aeolodicon, anemocorde (which could be classified as both a stringed keyboard instrument and a winded keyboard instrument), glass harmonica, and Cavaille's invention, the poikilorgan.

The most extensive chapter is on the wind instruments. This chapter covers issues of range, tonguing, and transposition for each of the instruments. The problematic issue of transposition and customary instrument names is first discussed in the article on the flute. Kastner's descriptions of the transposing flutes such as the tierce flute and flute in $\mathrm{E} b$ are deriven from a confusing tradition. Berlioz offers clarification on this topic in his Grand traité, explaining that what is now called the $\mathrm{C}$ flute was called the flute in $\mathrm{D}$ because the lowest note it could play was a D. Similarly, the D $b$ flute (or piccolo) was called the $\mathrm{E} b$ flute because when all the holes were covered, the note that the musician fingered was a D which sounded as an $\mathrm{E} b$. This same situation applies to the tierce flute being called the flute in F, even though it is really pitched in the key of $\mathrm{E} b$. This tradition could easily lead to confusion and transposition errors by young composers, so Berlioz advised abolishing the old way of naming the flutes and replacing it with a more accurate labeling based on the actual sounding pitch. Thus, the tierce 
flute would no longer be called the flute in $\mathrm{F}$, but rather the flute in $\mathrm{E} b$; similarly, the flute in $\mathrm{E} b$ would be called the flute in $\mathrm{D} b .{ }^{55}$ This change in naming conventions would apply to other flutes as well. For example:

A second type of piccolo is the piccolo in $\mathrm{E} b$ which is pitched a semitone higher than the preceding one; its written range is the same range, is an octave and a semitone higher than in the ordinary flute; for example:

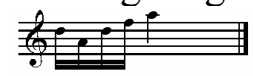

made on the flute in $\mathrm{E} b$ the sounding pitches of:

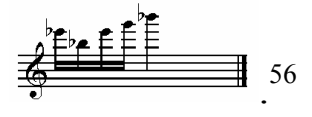

In addition to proper transpositions for all of the flutes and piccolos, the issue of scoring for two flutes is also addressed. Kastner also describes when these flutes and piccolos should be used in both orchestral and in military music. He lists methods for both the standard flute and the cane flute.

Despite its relatively limited range, the alphorn is the first instrument represented in the section on brass instruments because of its possible use in the theatre. The brass instruments are all first described by the notes that each instrument can play naturally, and then by notes that are obtained with the use of a crook, or in the case of the horn by means of placing the hand in the bell creating stopped tones. Because the horn is almost always used in pairs, the article on the horn contains musical examples of several ranges that are produced by using crooks and stopped tones for both first and second horns. Similar examples, which only used crooks or instruments tuned to different fundamentals, are provided for the trumpet and cornet.

Kastner addresses the technological innovation of the addition of pistons to certain brass instruments such as the horn, trumpet, cornet, and trombone. Both the horn and the cornet are described as having either two or three pistons, but the trumpet is described as having only two 
and the trombone as having only three. Kastner's detailed discussion of the valved trombone includes a fingering chart for the entire chromatic range.

The ophicleide is the newest instrument described in this treatise. There are several different ophicleides that are discussed, each with their respective range and transposition. The tablature chart is one of the most striking features of the ophicleide article. It includes an illustration of two different shapes of the ophicleide and chromatic fingering chart. Following the discussion on the ophicleide is a short section on the Apollonian lyre and the jaw-harp.

Kastner's final chapter, dedicated to the percussion instruments, features information on notation for all of these instruments. The article on the timpani covers the standard tunings of the large and small drum as well as outlining the possible uses for different tunings. A footnote describes the new mechanically tuned timpani, developed in Holland. In addition to the timpani, the standard orchestral instruments such as the bass drum, snare drum, triangle, and cymbals are presented. Some of the more unusual instruments that are described are the Turkish crescent, belfry, carillon, castanets, and systrum. The articles on the more exotic instruments are quite short, including only generalized descriptions and possible uses.

\section{Comparing Kastner with Berlioz}

It is not known when Berlioz and Kastner first met, but they had become friends by 1839 , and Berlioz later presented Kastner with an autograph manuscript of his Roméo et Juliette. ${ }^{57}$ When Kastner completed his Cours d'instrumentation in the same year, Berlioz gave both it and Kastner's earlier Traité positive reviews in the Journal des débats. Although Berlioz generally approved of Kastner's works on the subject of instrumentation, he felt that they were incomplete: 
Instrumentation, according to him, is the 'art of applying appropriate types of instruments to a given line of music'. Certainly it is, but it is much else besides. It is the art of using instruments to color the harmony and the rhythm; furthermore it is the art of generating emotion by one's choice of timbres, independent of any consideration of melody, rhythm or harmony. ${ }^{58}$

Berlioz's treatise fused the information found in both Kastner's Traité and Cours

d'instrumentation and included additional information about concerning the function of various instruments within the orchestral setting. Berlioz's commentary included many specific musical examples from contemporary literature. ${ }^{59}$ The description of the cymbals can be used as a point of comparison between the treatises of Kastner and Berlioz. Whereas Berlioz's treatise includes a delicately woven description of the instrument's timbre, Kastner's goal of producing a concise text led to a more sparse description. Kastner states that the "cymbals always play with the bass drum, triangle, and the like and do not have a specific key." ${ }^{, 60}$ However, Berlioz provideds a more lengthy description, stating that this "cymbals are very often used in conjunction with the bass drum, but as I have just observed of that instrument, they can often be used successfully on their own. Their high-pitched shimmering sound, with a noise that can be heard over every other noise in the orchestra, is ideal for various purposes..."61

Perhaps the "art of generating emotion by one's choice of timbres" ${ }^{62}$ that Berlioz referred to is best identified in this type of passage. However, this kind of description is not completely absent from Kastner's writing. An excellent example of this appears in the article on the tamtam. Kastner writes that "It is used only in terror scenes or funeral music... (In Turkey this instrument is used to call the faithful to the Mosque; the priests strike it on top of the minarets)" ${ }^{63}$ In this case Berlioz's article is only slightly more florid. Berlioz states that "the tam-tam, or gong, is used only for scenes of mourning or for the dramatic depiction of extreme 
horror...M. Meyerbeer has proved as much in the magnificent scene of the resurrection of the nuns in Robert le diable."

A passage from each writer's description of the bell clearly illustrates a parallel between the two treatises. Kastner writes:

the bell is used sometimes in the music of opera and as one can tune it to an unspecified pitch. Each time, it is written on the sounding pitch, thus it is the piece of music which always determines the note to be used... It is the composer who must choose the most suitable key. Mr. Rossini used a bell in G in the opera William Tell. Mr. Meyerbeer used a bell in $\mathrm{B}$ in the opera Robert le diable. ${ }^{65}$

Berlioz's description is strikingly similar, altering only one musical example, but even retaining the same composer:

Bells were brought into the orchestra more for dramatic than for musical reasons. The sound of deep bells is only appropriate for solemn or tragic scenes. High bells, on the other hand, give a more serene impression; they have a rather rustic, naïve quality especially suitable for religious scenes in a country setting. That is why Rossini used a little bell on high $g^{\prime}$ to accompany the graceful chorus in Act II of Guillaume Tell, with its refrain 'Voici la nuit', while Meyerbeer has used a bell on low $f$ to give the signal for the massacre of the Huguenots in Act IV of the opera of that name. ${ }^{66}$

Berlioz classifies and arranges the ordering of the instruments in his Traité in a manner that is substantially different than Kastner's ordering. The following chart clarifies the differences in the ordering of the instruments:

\section{$\underline{\text { Kastner's Treatise }}$}

\section{Berlioz's Treatise}

\section{Voices:}

Women's

Soprano

Mezzo-soprano

Contralto 
$\underline{\text { Kastner's Treatise }}$

Men's

Tenor

Baritone or Concordant

Bass

$\underline{\text { String Instruments: }}$

Bowed strings

Violin

Viola

Viola d'gamba

Viola Bastarda

Trumpet Marine

Viola d'amour

Viola di spala

Viola Bardone or Baritone

Cello

Double Bass

Plucked strings

Guitar

Guitar d'amour

Lyre

Cithre

Decachord

Bissex

Lute

Caliscone

Calichon

Pandarme

Theorbo

Mandore

Mandolin

Cittern

Harp

Gussel or Gusli

Harp ditale

Double-action harp

Psaltery

Aeolian Harp

\section{$\underline{\text { Berlioz's Treatise }}$}


$\underline{\text { Kastner's Treatise }}$

$\underline{\text { Keyboard: }}$

Keyboard with strings

Tympanon

Vielle

Clavacein

Piano

Keyboard with wind

Organ

Orchestrion

Barrel organ

Expressive organ

Accordian

Aelodicon

Eolicorde

Anemocorde

Glass harmonica

Harmonica (bois et paille)

Poikilorgan

Wind:

Woodwind

Flute

Panaylon or Flute in $\mathrm{G}$

Tierce Flute

Piccolo

Piccolo in E b

Calandrone

[Illegible in facsimile]

Cane flute

Fife

Recorder

Flageolet $\underline{\text { Berlioz's Treatise }}$

With keyboard

Piano 


\section{Kastner's Treatise}

Bassoon

Contrabassoon

Clarinet

Clarinet in $\mathrm{C}$

Clarinet in $\mathrm{B} b$

Clarinet in A

Bass clarinet in $\mathrm{B} b$

Clarinet in $\mathrm{E} b$

Clarinet in $\mathrm{F}$

Clarinet in D

Basset horn

Chalumeau

\section{$\underline{\text { Berlioz's Treatise }}$}

Bassoon

Tenoroon

Contrabassoon

Clarinet

\author{
Bass Clarinet
}

Basset horn

Saxophone

With keyboard

Organ

Melodium

Concertina

Brass with mouthpiece

Horn

Cor de chasse

Piston Horn

Cor omnitonique

Cor mixte

Cor russe

Trumpet

Cornet

Piston Trumpet

Piston Cornet

Keyed Trumpet

Demi-lune

Signal horn

Alto trombone

Tenor trombone

Bass trombone

Piston trombone

Cornetto or zinke
Trumpet

Cornet

Bugle 


\section{$\underline{\text { Kastner's Treatise }}$}

Alto ophicleide in $\mathrm{E} b$

Alto ophicleide in $\mathrm{F}$

Bass ophicleide in $\mathrm{C}$

Bass ophicleide in $\mathrm{B} b$

Monster ophicleide in $\mathrm{F}$

Bombardon

Apollonian Lyre

Jaw-Harp

\section{$\underline{\text { Berlioz's Treatise }}$}

Ophicleide

Bombardon

Bass tuba

Woodwind with mouthpiece

Russian bassoon

Serpent

Voices
Men
Women
Children
Castrati

Percussion:

Fixed pitch

Timpani

Timpani

Antique cymbals

Jeu de timbres

Glockenspiel

Keyboard harmonica

Bell

Bells

Belfry

Indeterminate pitch

Tambourine

Tenor drum or snare drum

Tambourine

Tenor drum

Side drum

Side drum

Bass drum

Bass drum

Triangle

Triangle

Cymbals

Cymbals

Turkish crescent

Turkish crescent

Tam-tam or gong 


\section{$\underline{\text { Kastner's Treatise }}$}

Chime

Castanets

Systrum

\section{Berlioz's Treatise}

Conclusion

What reason do we have for remembering Berlioz's treatise and forgetting Kastner's? It is not because Kastner's treatise lacked utility in comparison to Berlioz's. It is not because Kastner's treatise was unsuccessful from first publication. One reason for Berlioz's success is rooted in the evolutionary view of nineteenth-century society and Richard Strauss's role in Germanicizing and updating Berlioz's text. Kastner's was written for the young composer, whereas Berlioz's included a chapter on conducting and had the conductor as its intended audience, thus making it more attractive to Strauss. Even though Kastner's work was documented by German biographers, it failed to receive attention equal to that of Berlioz's work. Berlioz's status as a composer and conductor outshone Kastner's and as a result, Berlioz's writings gained more long-term recognition. However, Kastner's treatise is an excellent primary-source document from which much performance practice knowledge can be gleaned. The treatise offers detailed information on the use of orchestral instruments in composition and performance in the early nineteenth century.

A Note On The Translation and Editorial Procedures

The original text and its translation are presented in a side-by-side translation in order to give the reader better access to the original text. The musical examples are reproduced in both 
French and English in order to give the most accurate possible depiction of the source text. All musical examples and translations are provided by the author of this monograph. The footnotes were renumbered in a continual numbering sequence for a more consistent presentation in the side-by-side format. Each of Kastner's footnotes is located in the French column and the translation is demarcated by a forward slash ( / ). In addition to Kastner's footnotes, there are footnotes that provide full citations to writings by the people mentioned in Kastner's text. 


\section{INSTITUT DE FRANCE}

\section{ACADEMIE ROYALE DES BEAUX}

ARTES

Le Secrétaire; perpétuel de l'Académie.

Certifie que ce qui suit est extrait du

procès-verbal de la séance du 30 Juillet

1836.

Messieurs,

Vous avez chargé votre section de musique

d'examiner l'ouvrage de Mr. KASTNER, et de vous donner son avis, votre section

s'est empressée de satisfaire à votre désir, et le rapport que je vais avoir l'honneur de vous communiquer va vous faire connaitre notre opinion sur ce nouveau travail. Après un mûr examen, nous avons tous reconnu que l'ouvrage était complet, et qu'aucun des instrumens [sic] connus n'y avait été omis; que le diapason, l'étendue, les possibilités d'exécution de chacun d'eux y étaient détaillés avec précision et

\section{INSTITUTE OF FRANCE}

\author{
ROYAL ACADEMY OF FINE ARTS
}

The Permanent Secretary of the Academy

Certifies that what follows is an extract from the official report of the meeting on July 30, 1836.

Dear Sirs,

You charged your music division with examining the work of Mr. KASTNER, and with giving you its opinion of his work. Your division hastened to satisfy your request, and the report which I have the honor to communicate will make known our opinion on this new work.

After a thorough examination, we all recognized that the work was comprehensive, and that no known instruments had been omitted; that the pitch, range, and possibilities of execution of each one of them were detailed with precision 
clarté. En général la rédaction de cette encyclopédie instrumentale est bonne et le classement des matières y est bien entendu. Nous croyons qu'en tous temps ce sera un ouvrage fort utile aux jeunes compositeurs, car il pourra souvent venir en aide à leur manque d'expérience, c'est donc, nous le pensons, un grand service rendu à la culture de l'art musical, surtout à l'époque actuelle, où l'on fait jouer dans toute espèce de composition un si grand rôle aux orchestres.

Nous avons donc l'honneur de proposer à

l'Académie de vouloir bien accorder son approbation à notre rapport; ce sera, nous le pensons, rendre justice à Mr. KASTNER, et faire une chose utile à l'art.

Signé à la minute: LESUEUR, CHERUBINI, PAER, AUBER, HALEVY, BERTON, Rapporteur.

L'Académie adopte les conclusions de ce Rapport.

Certifié conforme, and clarity. In general the formatting of this instrumental encyclopedia is good, and the classification of the material is easily understood. We believe that it will be an extremely useful work for young composers of all times, because it will often be able to assist them in addressing their lack of experience; we think it is thus a great service rendered to the culture of musical art, especially at the present time, when, in any field of composition, orchestras play such a great role.

Thus, we have the honor of proposing that the Academy agree to grant its approval of our report; we believe it will do justice to Mr. KASTNER, and will be a service to the art.

Signed at the minute: LESUEUR, CHERUBINI, PAER, AUBER, HALEVY, BERTON, reporter.

The Academy adopts the conclusions of this report.

Certified, 
Le Secrétaire perpétuel de l'Académie, QUATREMÈRE DE QUINCY AVANT-PROPOS

En prêtant une oreille attentive aux des jeunes compositeurs et en étudiant avec conscience leur faire qui décèle le plus souvent, au milieu des plus riches idées mélodiques, une funeste inexpérience dans l'art de combiner convenablement la masse des instruments,

J'avais remarqué depuis long-tems [sic] qu'un ouvrage spécial traitant de l'instrumentation dans l'orchestre manquait à un genre d'études dont il est pourtant le corollaire et le complément indispensable. Parmi tant d'excellens [sic] traits que nous possédons sur toutes les autres branches de l'art Musical, personne n'avait encore sérieusement songé à combler cette lacune importante, il existe bien quelques Méthodes ou l'auteur a légèrement effleuré la matière, mais à force d'être courtes et concise, elles sont insuffisantes et
The Permanent Secretary of the Academy, QUATREMÈRE OF QUINCY FOREWORD

In lending an attentive ear to the works and in conscientiously studying that which appears most frequently, in the midst of the richest melodic ideas, a disastrous inexperience in the art of suitably combining the mass of instruments,

I had long since noticed that a work dealing specifically with orchestral instrumentation was nonexistent in a field of study to which it would be, moreover, an indispensable corollary and complement.

Among the many excellent treatises we on all the other branches of musical art, nobody had yet seriously thought of filling this significant gap. There are probably some methods whose author has touched upon the subject, but because they are of necessity short and concise, they are insufficient and incomplete. 
incomplètes.

Je ne me suis point dissimulé l'importance et les difficultés de la tâche que l'allais entreprendre, et ne pouvant invoquer en ma faveur, l'autorité d'un nom déjà connu dans le monde musical par quelque production antérieure, j'aurais peut-être hésité longtems à y faire on début qu'on aurait pu taxer d'imprévoyance ou d'orgueil si les encouragements de plusieurs hommes haut placés par leur génie et entr'autres [sic] de mes excellens et illustrés maîtres Henry Berton et Antoine Reicha n'avaient fini par triompher en partie de mes scrupules et de mes craintes.

Aujourd'hui, il m'est donc Presque permis d'espérer que le public appréciera l'utilité de cet ouvrage et ratifiera le jugement qu'en ont porté les plus hautes notabilités musicales de notre époque.

C'est surtout pour venir en aide aux jeunes
I was in no way incognizant of the importance and the difficulties of the task I was going to undertake, and not being able to call upon in my favor the authority of a name already known in the musical world through some earlier production, I would perhaps have hesitated a long time to begin what could have been considered to be an improvident or vain effort, if the encouragements of several men highly placed (by virtue of their genius), and among others excellent and famous masters Henri Berton and Antoine Reicha had not partially triumphed over my scruples and my fears.

Thus today, I have almost allowed myself to hope that the public will appreciate the usefulness of this work and will approve of the judgment that the highest musical notabilities of our time have bestowed upon it. It is mainly to aid young composers that I 
compositeurs que je me suis efforcé de

réunir dans ce volume tout ce qui a trait à

l'emploi des instrumens; mais comme mon

but a été non pas de faire étalage d'une

vaine science ou d'un purisme élégant mais

bien de former un ensemble où chacun pût

puiser à leur place les renseignements les

plus essentiels, j'ai cru devoir sacrifier à la

clarté dans les définitions la rondeur de la

phrase et l'élégance du style, sans tenir

compte des nombreuses redites où pourrait

m'entrainer ce système, j'ai cru devoir

glisser rapidement sur quelques parties

généralement connues de tout le monde et

m'appesantie au contraire plus

particulièrement sur certaines autres par où

pêchent d'habitude les jeunes hommes qui

se livrent au travail de la composition en un

mot mon seul instant d'avoir en vue en

écrivant ces pages.

Tout en donnant a cet ouvrage le plus grand développement possible j'ai été forcé de me renfermer dans certaines limites sous endeavored to bring together in this volume all that is connected with the use of instruments; but as my goal was not to make display of a vain science or of an elegant purism, but rather to form a collection from which everyone could draw the most essential information, I considered that I should have to sacrifice, for the sake of the definitions' clarity, well-shaped phrasing and elegant style. Without regard for of the many repetitions that this system could involve, I believed that I would have to gloss quickly over some parts generally known by everyone and concentrate instead on certain others which young men usually search for, who surrender themselves to the work of the composition; in short, my only goal in mind when writing these pages.

While developing this work as fully as possible, I was compelled to conform to certain restrictions, lest the book become 
peine de devenir long et diffus.

Ainsi que je l'ai déjà observé ce traité

concerne spécialement l'art de

l'instrumentation dans l'orchestre c'est-à-

dire, la manière la plus convenable

d'employer chaque instrument, et le bon ou

mauvais effet qu'il produit dans telle ou

telle circonstance, aussi, les compositeurs

qui voudront écrire expressément des Solo

Concerto ou Variations feront-ils bien de

consulter des Méthodes particulières, (que

j'ai indiquées a cet effet a la fin de chaque

article), et mieux encore des artistes versés

dans la connaissance de l'instrument pour

lequel ils auront l'intention de composer;

toutefois, autant que j'ai pu le faire sans

trop m'écarter de mon sujet j'ai indiqué la

manière de traiter chaque instrument dans

le Solo comme aussi dans la musique

d'harmonie ou militaire.

Tout l'ouvrage se divise en quatre grandes

classes ou catégories, savoir:

Les Instrumens à Cordes long and verbose.

As I have already noted, this treatise relates

to the art of orchestral instrumentation in

particular - that is, the manner most suitable

for each instrument's use, and the good or

bad effect which each instrument produces

in a given circumstance: also, composers

who will want to expressly write solo

concertos or variations would do well to

consult particular methods (which I

indicated for this purpose at the end of each

article) and better yet, they should also

consult those artists who are well versed in

the instrument for which they intend to

compose in any case, as much as I could do

without straying too far from my subject, I

have indicated the manner of treating each

instrument in solo as well as in orchestral or military music.

This work is divided into four large classes or categories, namely:

Stringed Instruments 
Les Instrumens à Clavier

Les Instrumens à Vent

Les Instrumens à Percussion

J'ai fait précéder ces quatre chapitres d'un résumé sur les voix.

Tout naturellement, dans les quatre grandes

divisions adoptées ci-dessus, sont venues

se ranger plusieurs subdivisions que j'ai eu

soin de disposer dans leur ordre successif,

par exemple:

Pour les Instruments à Cordes:

Instruments à cordes mises en vibration

par un archet

Instruments à cordes Pincées

Pour les Instruments à Clavier:

Instruments à clavier à cordes

Instruments à clavier à vent

\section{Keyboard Instruments}

\section{Wind Instruments}

\section{Percussion Instruments}

I have preceded these four chapters with a summary of the voices.

Quite naturally, in the four main sections adopted above, there are several subdivisions which I have taken care to lay out in their successive order, for example:

String instruments:

Bowed string instruments

Plucked string instruments

Keyboard instruments:

Keyboard instruments with strings

Wind keyboard instruments
Pour les Instruments à Vent:

Instruments à Vent en bois

Instruments à Vent en Métal

Enfin ces subdivisions en comprennent
Wind instruments:

$$
\text { Woodwind instruments }
$$

Brass instruments

Finally, these subdivisions include still 
encore d'autres qui classent les Instruments par familles.

Quelques Instruments semblent, par leur nature, appartenir, en même temps, à plusieurs des quatre grandes divisions indiquées ci-dessus; comme l'Orgue qui est à la fois un instrument à Clavier et à vent, la Harpe Eolienne qui est à la fois un instrument à cordes et à Vent, \& . Pour éviter le pêle-mêle et la confusion où je n'aurais pas manqué de tomber en faisant de ces divers instruments une cinquième catégorie à part, j'ai cru devoir les rattacher, chaque fois, à celle des quatre grandes divisions, dans laquelle ils me semblaient le plus particulièrement rentrer, par leur but et leur essence.

Quant aux instruments d'un trop minime intérêt pour mériter un article à part, je les ai notés en remarque, pour mémoire.

Enfin, il est des instruments que j'ai cru devoir omettre entièrement pour des others which classify the instruments by families.

At the same time, some instruments seem, by their very nature, to belong to several of the four large divisions indicated above; for example the organ which is both a keyboard and wind instrument; the Aeolian Harp which is both a string and wind instrument; and so on.

To avoid the redundancies and confusion in which I would inevitably have fallen prey if I had created a fifth section devoted to these instruments, I felt it best to include them in the other four sections; each to the division in which it seemed to belong best.

As for the instruments which are of too little interest to merit an independent article: I have included them in the remarks, for the record.

Lastly, there are those instruments I deemed necessary to omit entirely for reasons that I 
raisons que j'expose à la fin de ce volume. explain at the end of this volume.

Puisse mon travail trouver chez les artistes May my work be benevolently and

un accueil bienveillant et favorable,

puissent-il leur épargner des recherches

souvent infructueuses, toujours fatigantes

et pénibles, et, mon but aura été atteint, et

je me croirai suffisamment indemnisé des

peines et des soins qu'il m'aura coûtés !

NOTE ESSENTIELE

J’ai remarqué que dans la langue

Française, il n'existe pas le terme propre pour indiquer chaque octave, et désigne

habituellement par $1^{\text {ere }}, 2^{e}$, \& a expression qui non seulement n'offre pas à l'esprit un

sens fixe, mais c'est tout-à-fait [sic]

insuffisante pour désigner l'étendue de

chaque instrument, j'ai cherché à faire

disparaître cette par une appellation plus

franche, imitée de l'Allemand, j'offre en

conséquence de donner aux différentes

noms ci-dessous indiqués, et j'ai la

satisfaction d'appuyer ma proposition sur

le suffrage si concluant des maîtres Henri favorably received by artists; may it save

them from research that is often unfruitful, always tiring and painful. My goal having

been reached, I will believe myself

sufficiently compensated for the trouble and

care that it have cost me!

ESSENTIAL NOTE

I noticed that in the French language, there

is no proper term for designating each

octave, and they are usually indicated by

first, second, and the like, these expressions

which not only fail to offer the mind a fixed

point of reference,, but are completely

insufficient to indicate the range of each

instrument. I have endeavored to resolve

this problem through the use of a more

direct designation, an imitation of the

German, which I accordingly offer to give

to the different names indicated below, and

I have the satisfaction of basing my

proposal on the conclusive vote of masters 
BERTON et Antoine REICHA.
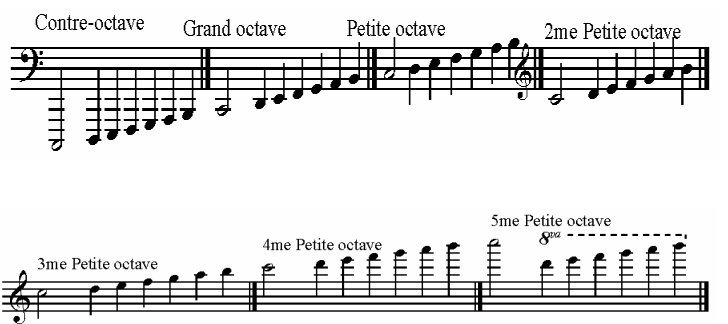

Henri BERTON and Antoine REICHA.
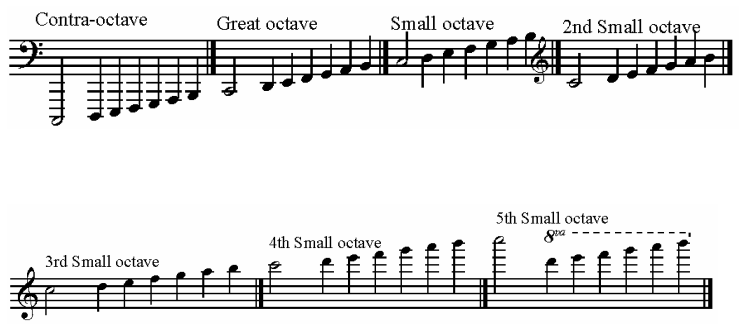
CHAPITRE 1

LES VOIX

Les voix se divisent en voix de femmes et en voix d'hommes.

Les voix de femmes se subdivisent en deux parties générales que l'on nomme: Soprano et Contralto; mais comme parmi les voix de femmes il y en a beaucoup qui ne descendent pas tout-à-fait autant que le Contralto on a encore adopté pour ces voix une troisième subdivision qu'on appelle Mezzo-Soprano.

Les voix d'hommes se subdivisent aussi en deux parties générales appelées Ténor et Basse, une troisième subdivision a également lieu pour les voix qui tombent entre le Ténor et la Basse, on les appelle: Baryton ou Concordant. Voici l'étendue de ces six sortes de voix:

\section{CHAPTER 1}

\section{VOICES}

The voices are divided into women's and men's voices.

The women's voices are subdivided in two general parts that are called: Soprano and Contralto; but since among women's voices there are many whose range does not descend as low as the Contralto, a third subdivision, called Mezzo-Soprano, has been adopted for these voices.

The men's voices are also subdivided into two general parts called: Tenor and Bass. A third subdivision is also found for the voices which fall between Tenor and the Bass, called: Baritone or Concordant.

Here are the ranges of these six kinds of voices: 
Soprano

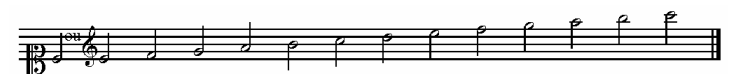

Chromatiquement

Mezzo-Soprano

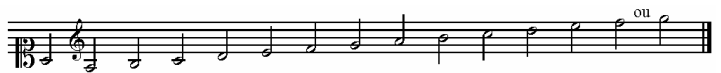

Chromatiquement

Contralto

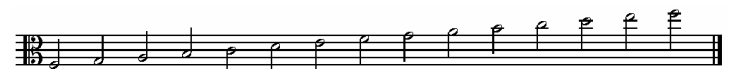

Chromatiquement

Ténor

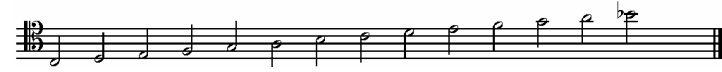

Chromatiquement

Baryton ou Concordant

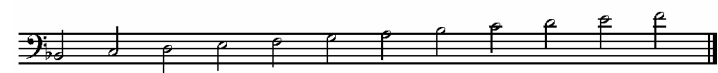

Chromatiquement
Soprano

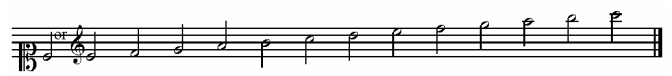

Chromatically

Mezzo-soprano

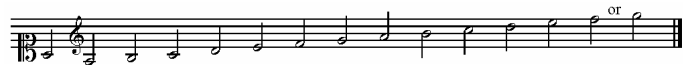

Chromatically

Contralto

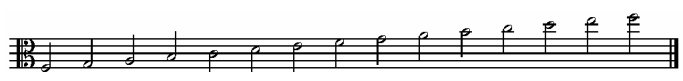

Chromatically

Tenor

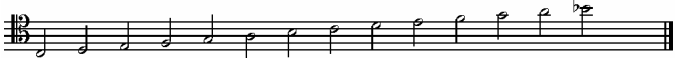

Chromatically

Baritone or Concordant

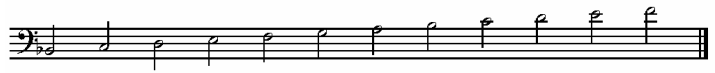

Chromatically 
Basse-Taille

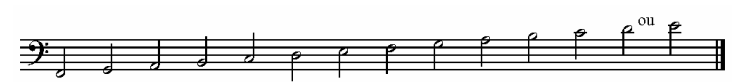

Chromatiquement

Ces différentes étendues de voix ne sont

pas toujours invariablement praticables, parcequ'il [sic] y en a qui montent plus haut que le diapazon $[s i c]$ indiqué d'autres qui descendent plus bas, et d'autres qui ont moins de notes dans leurs registres.

Pour faire valoir les diapazons [sic] de voix extraordinaires, il faut spécialement composer pour les individus qui en sont doués, ce qui ne peut jamais se faire que dans des Airs ou des Solos, et point dans des Chœurs, comme on le verra cidessous. $^{67}$

La nature a donné la possibilité de chanter beaucoup plus haut que les notes naturelles rendues par la poitrine, en se servant d'un procédé nommé Fausset ou Voix de tête, cette addition extraordinaire et dont on ne fait jamais usage dans les Chœurs a un timbre tout particulier.
Bass

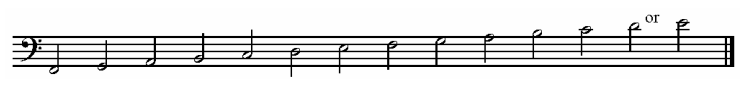

Chromatically

These different vocal ranges are not always practicable, because there are some whose range extended higher than the pitch indicated, others who go lower, and still others who have fewer notes in their registers.

To highlight the pitches of unusual voices, one must compose specifically for the individuals who are thus endowed, which can not be done in arias or solos, and not in choruses, as will be shown below.

Nature gave the possibility of singing much higher than the natural notes produced by the chest, by using a process called falsetto or head voice; this extraordinary addition, which is never used in choruses, has quite an unusual timbre. 


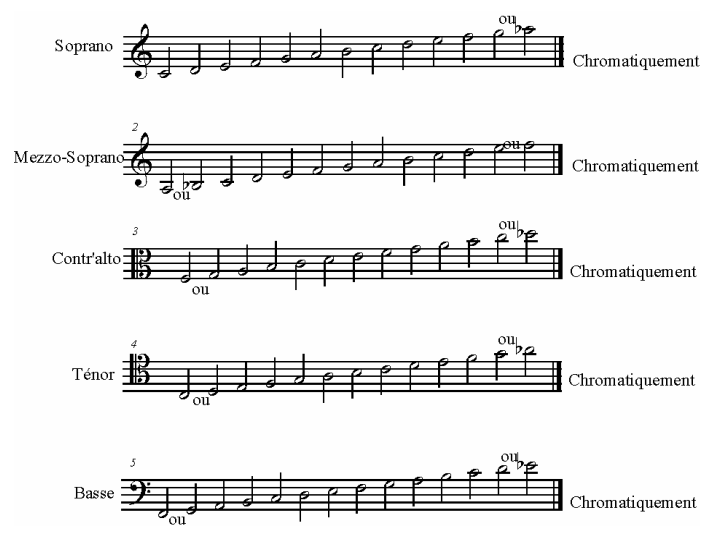

Les deux notes les plus graves et les plus élevés, faisant l'extrême de chaque partie ne s'emploient pas fréquemment et elles sont d'un usage beaucoup plus rare que les autres appelées notes du médium car elles sont au grave, très faibles et peu sonores; et à l'aigu trop fatigantes et souvent criardes; ainsi, en se maintenant fréquemment - dans ces deux extrêmes, on ne ferait que fatiguer les artistes; c'est pourquoi, comme nous venons de le dire, on doit employer de préférence les notes du medium, qui sont celles-ci:

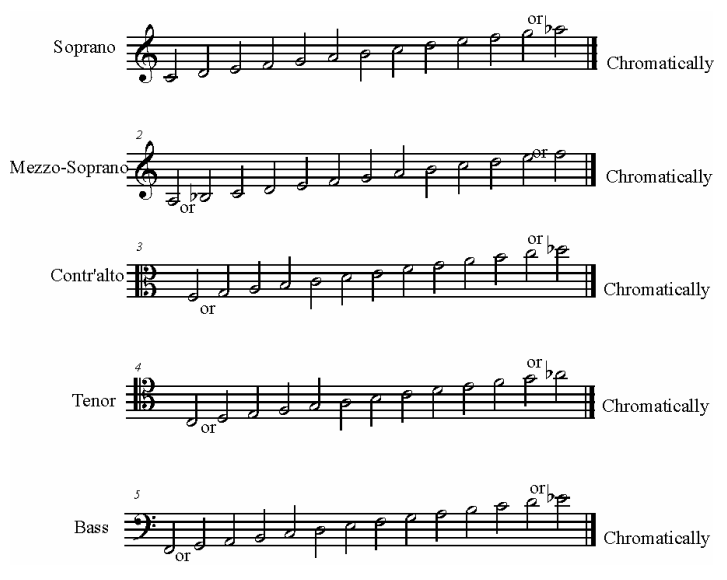

The two lowest and highest notes which comprise the extreme of each vocal part are not frequently used and they are used much more rarely than the others called notes $d u$ médium because they are in the low register, very weak and quiet; and the higher register they are too tiring and often require a “yelling" effect; thus, by frequently using the highest and lowest notes - in these two extremes, one would do nothing but tire the artists; this is why, as we have just said, one must preferably employ the notes $d u$ médium, which are indicated here: 


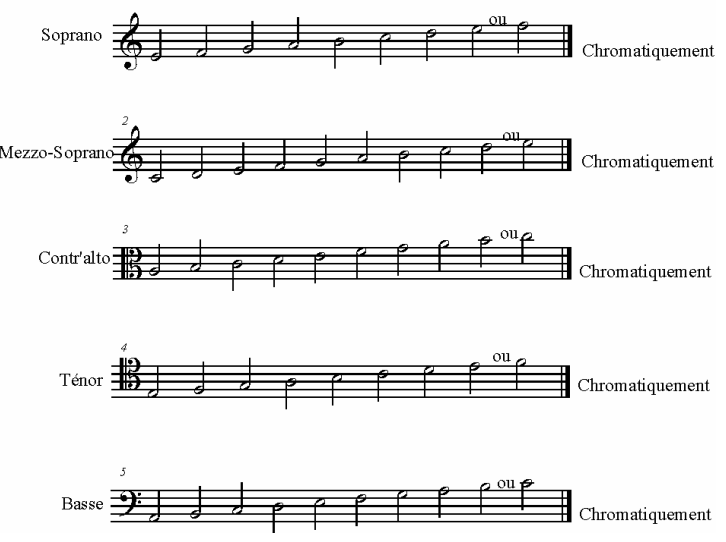

Les voix de Contr'alto [sic] sont en général assez rares, mais on les remplace facilement par les Mezzo-soprano, ou 2me dessus, qui sont beaucoup plus nombreux. Observation. Il y a des Chœurs d'hommes seuls, ou de femmes seules (ces derniers s’appellent aussi Chœurs à voix blanches,) et enfin des Chœurs d'hommes et de femmes réunis.

En composant des chants pour voix d'hommes seulement; on est souvent indécis par le peu d'étendue qu'offrent ces voix, si l'on doit écrire à 3 ou à 4 parties, parceque [sic] l'harmonie étant serrée au grave, ne produit pas bon effet; c'est pourquoi il est à conseiller d'employer souvent l'unisson pour les voix, tandis que

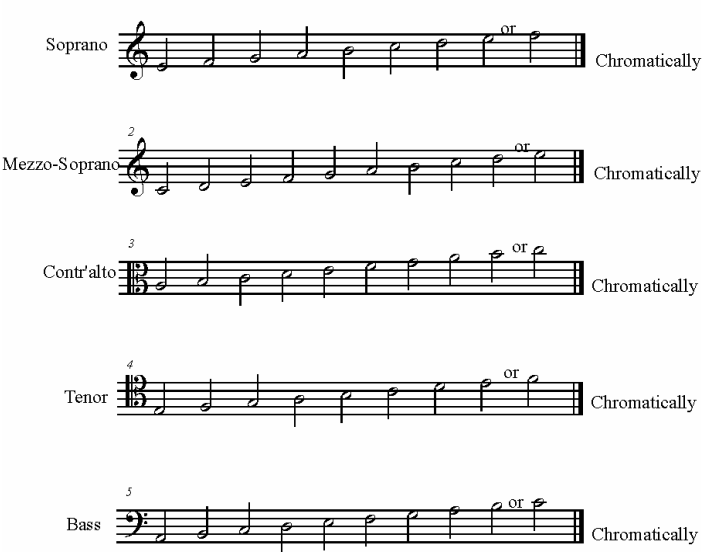

The Contr' alto voices are in general rather rare, but one easily replaces them with the Mezzo-sopranos, or the second of the above example, which are much more common. Observation. There are choruses of men only, or women only, (the latter are also called "white voice choruses") and finally choruses of men and women together.

When composing for men's voices alone, one is often distracted by the lack of range which these voices offer when one must write three or four part harmony, because tight harmony in the lower register does not produce a good effect. This is why it is often advisable to use unison for the voices, while the orchestra plays the harmony. For 
l'orchestre fait l'harmonie; c'est par cette même raison que l'harmonie à 2 ou à 3 parties est préférable à celle qui en a quatre.

La même inconvénient n'existe pas pour les Chœurs à voix blanches, parceque l'harmonie peut être fort serrée à l'aigu, sans inconvénient; ainsi des Chœurs de femmes à 2,3 et 4 parties sont plus faciles à écrire que des Chœurs d'hommes.

Lorsqu'on réunit les voix d'hommes aux voix de femmes, on fait bien de remplacer souvent le Contr'alto par le 2 me dessus, comme nous l'avons déjà observé; et surtout si l'on a un grand nombre de chanteurs à sa disposition.

Nous avons des Solfèges de Balleux, Barsotti, Bisch, Borde, Choron, Denis, Dupont, Fétis, Garaudé, Gibert, Kuhn, Panseron (Solfège de Rodolphe revu par lui), Rodolphe, Wilhem et autres. ${ }^{68}$ Nous avons des Méthodes de chant de this same reason, two or three part harmony is preferable to that of a quartet.

The same disadvantage does not exist for Women's Choruses ("White Voice" Choruses) because the harmony in the higher registers can be extremely tight without disadvantage; thus women's choruses with two, three, and four parts are easier to write than men's choruses.

When men's and women's voices are joined together, the contr'alto may be replaced by the second example above, as has already been observed; especially if there is a great number of singers at the composer's disposal.

There are solfege methods by Balleux, Barsotti, Bisch, Borde, Choron, Denis, Dupont, Fétis, Garaudé, Gibert, Kuhn, Panseron (Rodolphe's Solfege method reexamined), Rodolphe, Wilhem and others. There are singing methods by Andrade, 
Andrade, Bordogni, Catrufo, Choron, Bordogni, Catrufo, Choron, Ferrari, Danzi,

Ferrari, Danzi, Schubert, Kauer, Frochlich, Schubert, Kauer, Frochlich, Benelli,

Benelli, Mainzer, Stoepel (Fr.), Nägeli, $\quad$ Mainzer, Stoepel (Fr.) Nägeli, Garaudé,

Garaudé, Hiller, Gérard, Haeer, Martini, $\quad$ Hiller, Gerard, Haeer, Martini, Pellegrini

Pellegrini et autres. and others. 
CHAPITRE II (Instruments à cordes)

\section{LE VIOLON}

Le violon s'écrit généralement sur la clef de Sol $2^{\text {me }}$ ligne, on l'emploie dans

l'orchestre par $1^{\mathrm{r}} 2^{\mathrm{e}}$ quelquefois aussi par $3^{\mathrm{e}}$ et même lorsqu'il y a des Solos, on ajoute encore à ceux-ci un violon principal.

Le violon a quatre cordes qui s'appellent en commençant par la plus grave: Sol, Ré, La, Mi, (ou chanterelle;) ainsi donc l'accord des cordes est par quintes parfaites:

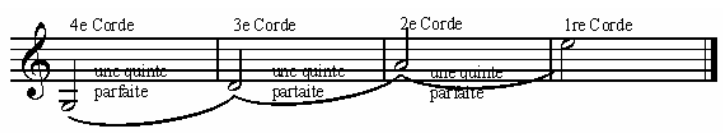

L'étendue générale du violon commence au Sol de la petit octave, et va jusqu'à l'Ut, ou même Ré et Mi de la $5^{\mathrm{e}}$ petite octave; mais, comme dans presque tous les instrumens, les sons les plus élevés sont d'une exécution difficile et demandent beaucoup d'habileté, l'étendue des instrumens est plus bornée dans l'orchestre que dans le concerto, parce que la musique d'orchestre doit s'exécuter à première vue, tandis
CHAPTER II (String instruments)

\section{THE VIOLIN}

The violin is generally notated in the treble clef. It is used in the orchestra in one, two, and sometimes three parts and even when there are solos, a principal violin may be added.

The violin has four strings which are called, starting from the lowest: G, D, A, E (or chanterelle); thus the tuning of the strings is in perfect fifths:

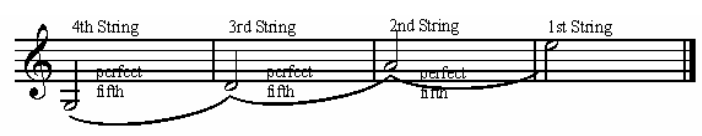

The general range of the violin starts at $G$ of the small octave, and extends to $\mathrm{C}$, or even D or E of the fifth small octave. But as with almost all instruments, the highest tones are difficult to play and require considerable skill. The range of the instruments is limited in orchestra more than in concerto, because orchestral music must be performed at first sight, whereas one rehearses that of a concerto; thus, a 
qu'on étudie celle de concerto; ainsi donc, violin part in orchestral music should not on ne doit pas écrire plus haut le violon que be written higher than G or A of the fourth Sol ou La de la $4^{\mathrm{e}}$ petite octave. small octave.

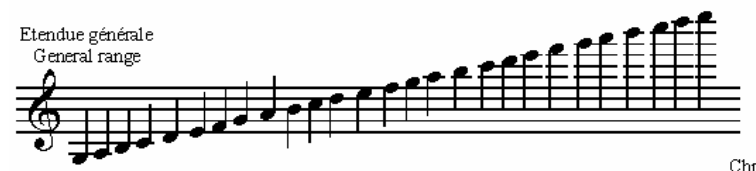

Sur toute cette étendue on peut facilement exécuter les trilles et même les doublestrilles; ces derniers offrent pourtant déjà quelque difficulté, c'est pourquoi on ne peut les employer que dans les solos

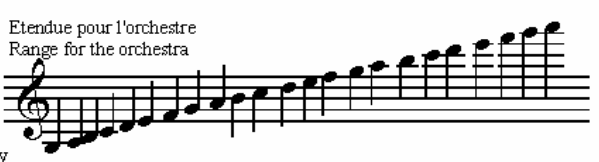
Chromatically

Trills and even double-trills can be played easily over the range of the instrument; because the latter proves difficult however, one can only use them in solos (concertos). (concerto).

EXEMPLE de doubles-trilles

EXAMPLE of double-trills
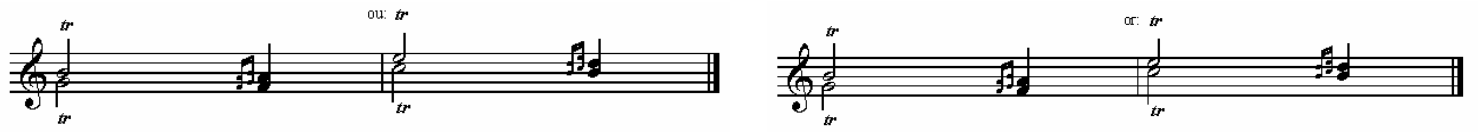

Les notes les plus hautes ne doivent

The highest notes should not be used s'employer que dans les fortissimo, except in fortissimo, because they are parcequ'elles sont jouées d'ordinaire par usually played by several violins, which plusieurs violons, qui souvent ne les often do not play them quite in tune, and donnent pas toutes bien exactes, ce qui thus would naturally produce a very bad naturellement produirait un très mauvais effect. One can use fortissimos very well effet; mais on peut très bien les employer in solo passages ${ }^{69}$, played by a single dans des passages de Solo, exécutés par un violon seul; toutefois le compositeur qui violin; however the composer, who wishes to use this technique without 
voudra s'en servir, sans connaître lui même

le violon, devra consulter auparavant un bon artiste sur la composition.

En général, pour bien écrire les parties de violon, il faut connaître à fond l'étendue de ses propriétés; les sept différentes

positions, le démanché de l'instrument; ainsi que les précautions à prendre dans les traits où il faut que la main monte et surtout descende avec rapidité d'une position à une autre; les doubles-cordes naturelles et altérées, praticables avec plus ou moins d'effet; la manière d'écrire les arpèges; les phrases finales convenables à chaque ton en particulier; la sourdine, le pizzicato, $\& \&$.

Du reste, le violon, comme tous les autres instrumens à cordes, étant généralement assez connu et presque tous les passages, (si ce n'est ceux de concert,) pouvant s'exécuter à première vue par les artistes de knowing how to play the violin himself, must first consult a good artist about the composition beforehand.

In general, it is necessary to possess an indepth knowledge of the range of the violin's properties. This includes the seven different positions, and the shifting of positions on the instrument in order to write violin parts well, as well as the precautions to be taken in the cases where it is necessary for the hand to go up and especially to go down quickly from one position to another; the natural and altered double-stops, practicable with greater or lesser effect, as desired; the manner in which one writes the arpeggios; cadences suitable to each key in particular; the mute, the pizzicato, and the like. Moreover, since the violin, like all other stringed instruments, is generally well known and almost all the passages (if they are not those in concert) can be performed at first sight by today's artists, it is easier 
nos jours, il en résulte qu'il est plus facile de composer d'une manière conyenable $[$ sic $]$ pour les instrumens à cordes que pour ceux à vent; d'un autre côté le peu de volume de cet ouvrage ne nous permettant pas d'entrer dans de trop longs détails, nous glisserons sur les instrumens à cordes, aussi vite que possible, et nous nous arrêterons au contraire aux instrumens à vent; car c'est par là que pêchant ordinairement les jeunes compositeurs à qui cet ouvrage est spécialement destiné.

Il faut observer que le second violon s'écrit toujours plus bas que le premier; cependant on peut le faire monter plus haut si le passage l'exige absolument.

Si l'on veut qu'un passage lié à une mélodie simple résonne pleinement et soit bien rempli, comme

Par EXEMPLE:

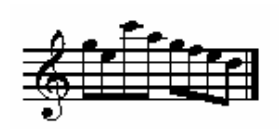

on devra l'écrire de la manière suivante: to suitably compose for stringed instruments than it is for winds. On the other hand, as the small size of this report does not allow us to enter into too much detail, we will skim over the stringed instruments as quickly as possible, and focus more on the wind instruments; because it is in this division that young composers, for whom this work is especially intended, usually err most frequently.

It should be observed that the second violin is always written lower than the first; however one can raise it higher if the passage absolutely requires it.

If one wants a passage related to a simple melody to resonate fully and to be full, for example:

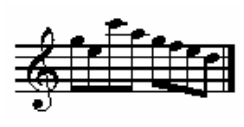

one will have to write it in the following way: 


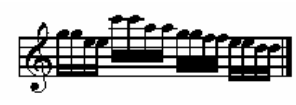

ou en abrégeant:

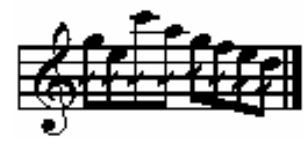

ou encore:

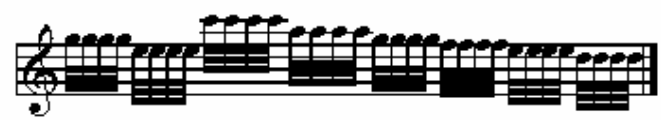

Cela dépend du mouvement.

On sait d'ailleurs généralement que, dans

l'orchestre, bien que souvent plusieurs

instrumens à vent jouent encore plus haut

que lui, le premier violon tient toujours la

partie principale, d'abord parceque la partie

de violon est exécutée par un certain

nombre à la fois, et ensuite parce que

l'oreille. Après avoir remarqué une fois la

marche de cet instrument, le suit toujours,

lors même que d'autres instrumens font

entendre des notes plus élevées. On fait

exception à cette règle quand un ou

plusieurs instrumens jouent des Solos, et

qu'alors le violon est employé comme

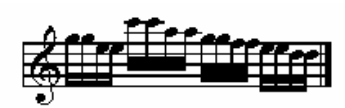

or by abbreviating:

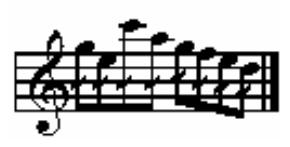

or even:

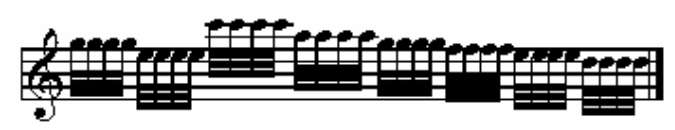

This depends on the tempo.

It is generally known that, in the

orchestra, although several wind

instruments often play even higher than it, the first violin always holds the principal

part, primarily because the violin part is

played by a given number of musicians at the same time, and secondly because the ear, after having once noticed this instrument, always follows it, even when other instruments play higher notes. An exception to this rule is when one or more instruments play solos. In this case, the violin is employed as an accompanying instrument. 
instrument d'accompagnement.

Pour les doubles-cordes, on doit de

préférence se servir de cordes à vide:

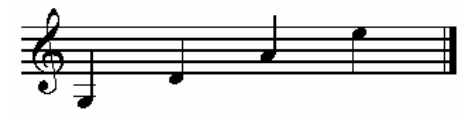

En doubles-cordes $[$ sic $]$ :

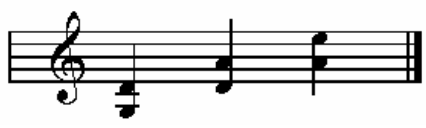

Il y a aussi des doubles-cordes sans cordes à vide, pourvu toutefois que les deux notes ne soient pas plus basses que $R e^{\prime}$ de même, dans un accord de trois notes, il ne faut pas que les tons soient pas plus basses que $L a$ de quatre notes plus bas que $M i$

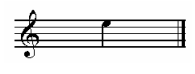

Enfin, il ne faut pas écrire de doublescordes pour la corde la plus haute et la $3^{\text {me }}$ ou pour la seconde et la $4^{\text {me }}$ corde, parceque l'archet ne peut atteindre les cordes extérieures sans toucher celles du milieu.

Les doubles-cordes naturelles sur la $4^{\text {me }}$ et $3^{\text {me }}$ corde, à la première position, sont:
It is preferable to use open strings for double-stops:

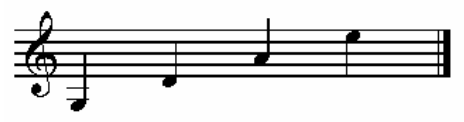

In double-stops:

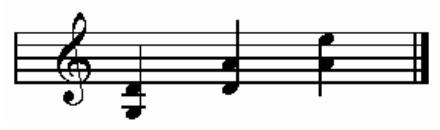

There are also double-stops without open strings, provided however that the two

notes are not lower than $\mathrm{D}$ Likewise, in a harmony with three notes, the notes should not be lower than A

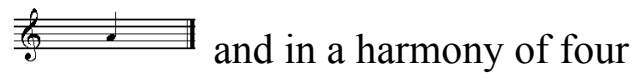

notes not lower than $\mathrm{E}$

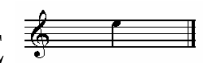

Lastly, one should not write double-stops for the highest string and the third, or for the second and the fourth string, because the bow cannot reach the outside strings without touching those in the middle.

The natural double-stops on the fourth and third strings, in first position, are: 


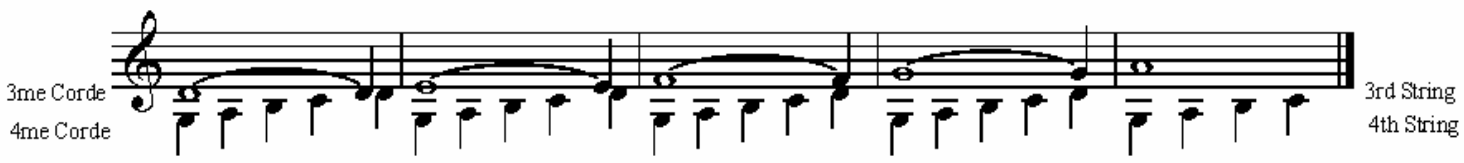

Les doubles-cordes naturelles sur la $3^{\text {me }}$ et The natural double-stops on the third and $2^{\text {me }}$ corde, à la première position, sont: $\quad$ second strings, in first position, are:

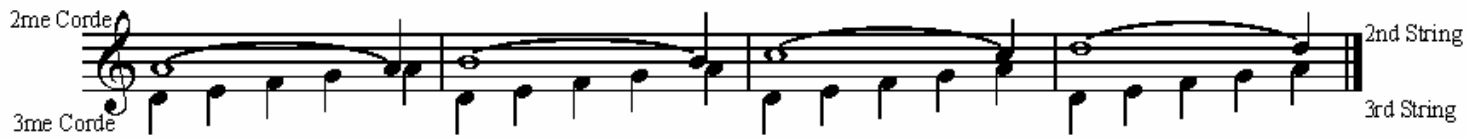

Les doubles-cordes naturelles sur la $2^{\text {me }}$ et The natural double-stops on the second $1^{\mathrm{re}}$ corde, à la première position, sont: $\quad$ and first strings, in first position, are:

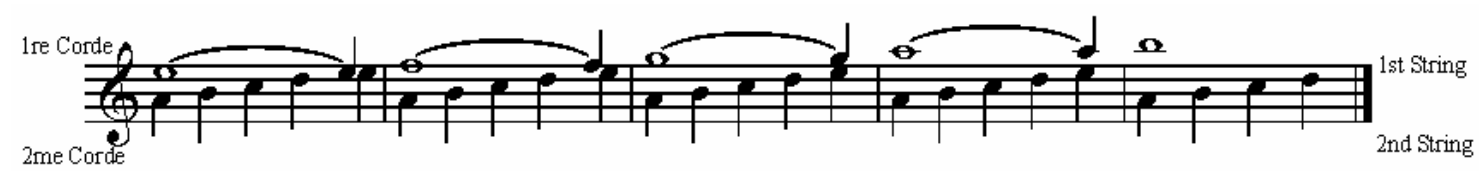

Quant aux doubles-cordes altérées à la première position, on peut altérer la $4^{\mathrm{me}}$ et la $3^{\mathrm{me}}$ du Ré\#/Sol jusqu'au $L a / U t \#$

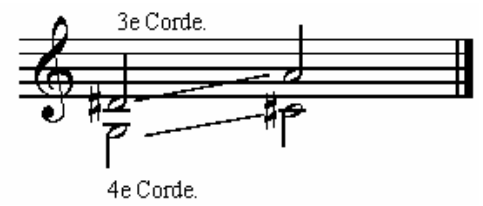

2me du La/Ré\# jusqu'au Ré\#/Sol\#

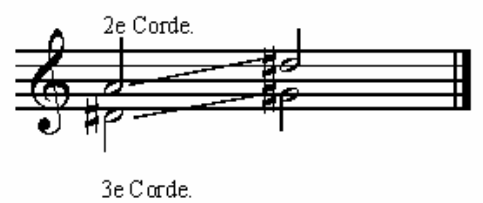

du Mi/La jusqu'au Si/Ré\#

la 2 me et la $1^{\text {re }}$
As for altered double-stops in first

position, one can alter the fourth and the

third of $\mathrm{D} \sharp / \mathrm{G}$ to $\mathrm{A} / \mathrm{C} \#$

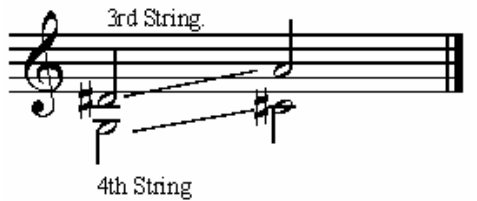

the third and the second of $\mathrm{A} / \mathrm{D} \#$ to $\mathrm{D} \sharp / \mathrm{G} \sharp$

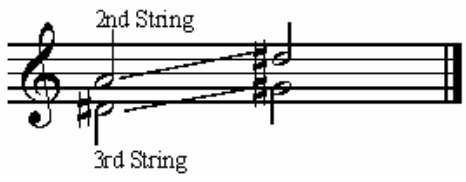

the second

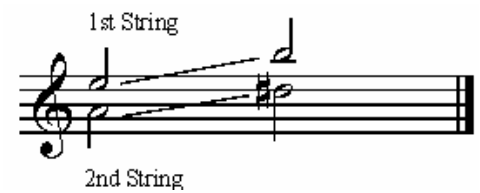




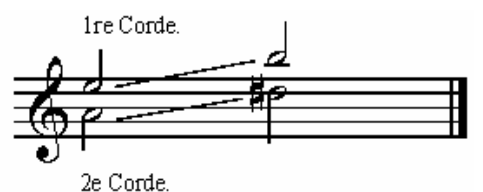

Il est bien entendu que dans les exemples précédens [sic], toutes les doubles-cordes naturelles entre les deux autres, peuvent aussi être altérées.

On peut employer les doubles-cordes dans des passages rapides, comme:

ou comme notes tenues, par exemple: $\frac{\hat{i} 2 \hat{i}}{20}$

Quant aux doubles-cordes naturelles et altérées de la seconde position, on ne peut proprement employer avec effet que celles de la $1^{\text {re }}$ et $2^{\text {me }}$ corde

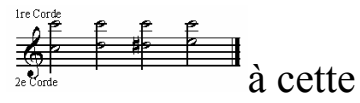
position, celles de la $2^{\text {me }}$ et $3^{\text {me }}$
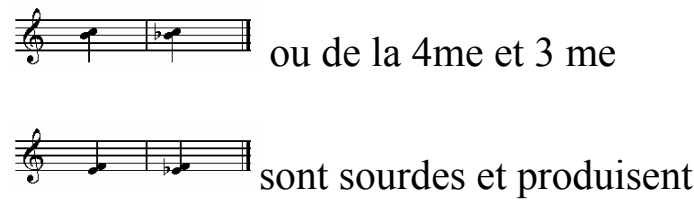

peu d'effet; il faut donc les éviter et tâcher de les employer à la première position, par

exemple:

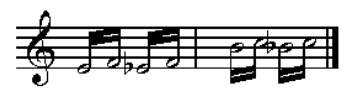

It is well understood that in the preceding examples, all the natural double-stops between the two others can also be altered.

One can use double-stops in fast passages,

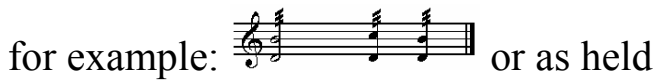

notes, for example: $\frac{\hat{i}}{i c \mid}$

As for the natural and altered double-stops in second position, one can use with good effect only those of the first and second

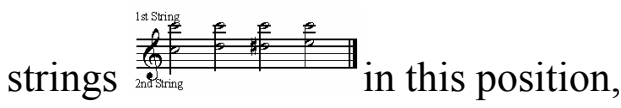
those of the second and third or of the fourth and third are muffled and produce little effect; it is thus necessary to avoid them and try to use them in first position, for example:

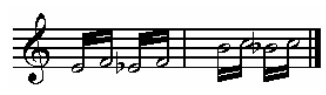


Les doubles-cordes naturelles et altérées de The natural and altered double-stops of la $3^{\text {me }}$ position, sont également sourdes et the third position are also muffled and of de peu d'effet, à l'exception toutefois de little effect, except however for those celles produites par la $2^{\mathrm{me}}$ et $1^{\text {re }}$ corde; $\quad$ produced by the second and first strings; exemple: for example:
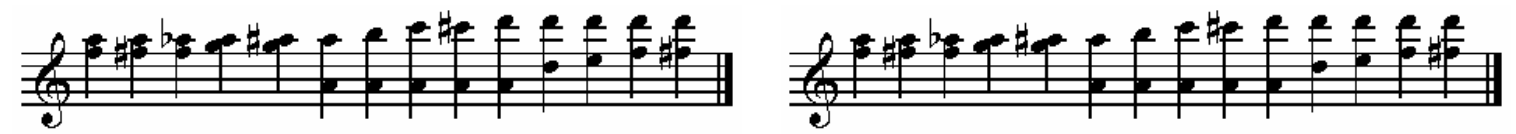

Les doubles-cordes de la $3^{\text {me }}$ et $4^{\text {me }}$ corde et celles de la $3^{\text {me }}$ et $2^{\text {me }}$

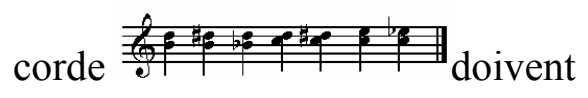

s'employer comme suit, à la première

position, étant sourdes et sans effet à la troisième;

The double-stops of the third and fourth

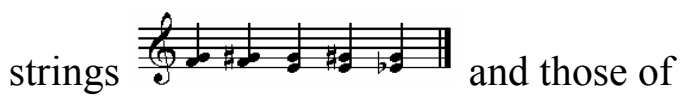

the second and third strings

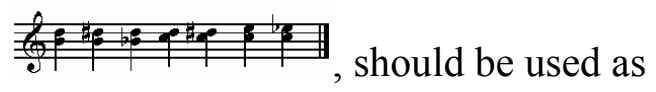

follows, in first position, as they are

muffled and without effect in the third;

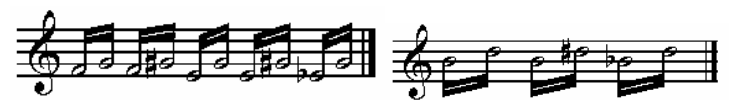

des accords de trois ou quatre tons comme:
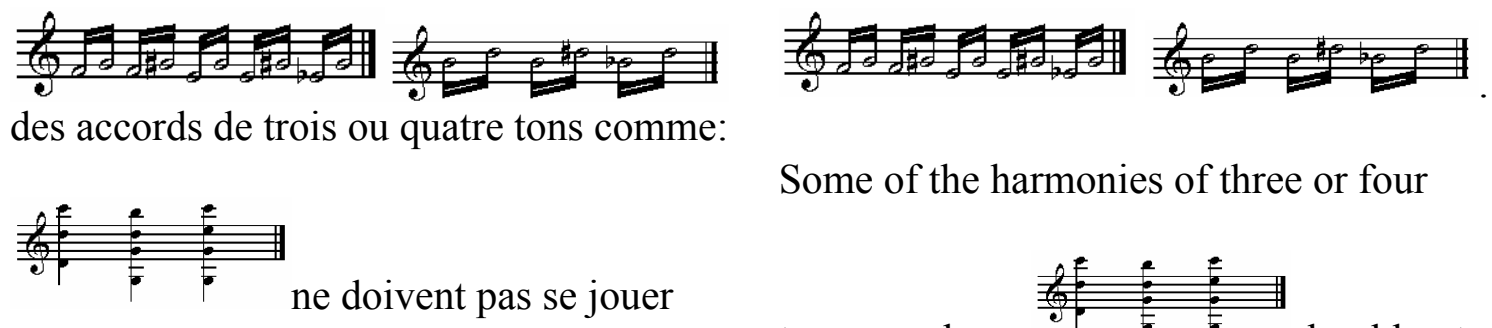

Some of the harmonies of three or four

trop vite, parce que tous les tons de ces

accords ne pouvant être rendus

simultanément, il en résulte un effet

d'accord brisé.

Exemple:

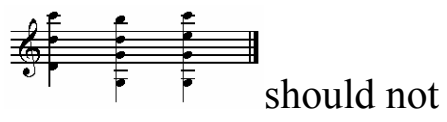

be played too quickly, because all the

tones of these harmonies cannot be

sounded simultaneously, which results in

the effect of a broken chord.

For example: 


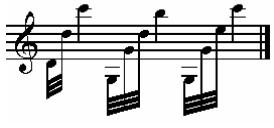

On voit d'après cela qu'on peut demeurer long-tems sur tous les intervalles d'un pareil accord, et même, si on le voulait absolument, on obtiendrait l'effet de

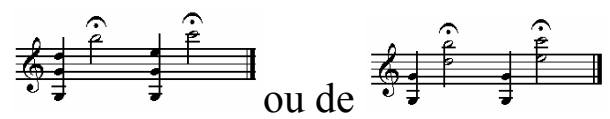

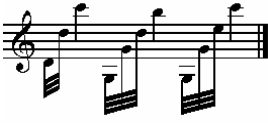

One sees from this example, that one can sustain all the intervals of a similar harmony for a long time, and even, if it were absolutely wanted, one would obtain
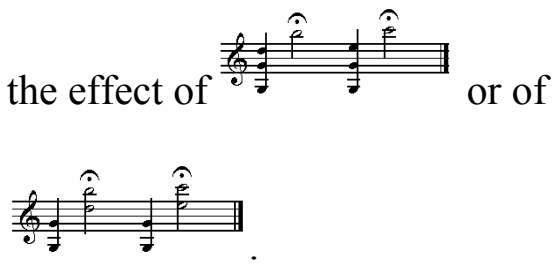

On emploie très souvent les arpèges sur le violon; mais il ne faut pas croire qu'on violin; but it should not be believed that puisse les y faire comme sur le piano-forte. one can produce them as on the Le doigté du violon étant tout particulier, il pianoforte. The fingering of the violin faut s'efforcer d'en faire l'apprentissage, being very specialized, one must strive to ou du moins, bien connaître la manière de noter les arpèges, afin de ne pas manquer souvent l'effet qu'on a cru obtenir. Tous ces accords peuvent être mis en arpèges; Exemple: Accords à trios cordes:

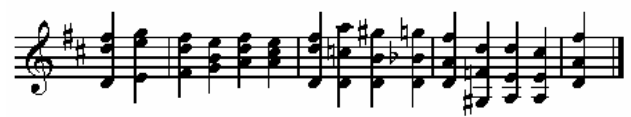

learn it well or at least, to know well the manner of notating arpeggios, in order not to often miss the desired effect.

All these harmonies can be put in arpeggios; for example:

Three string chords:

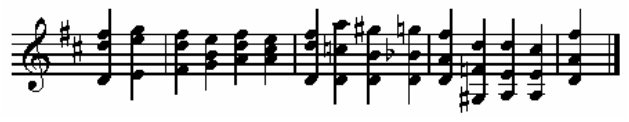




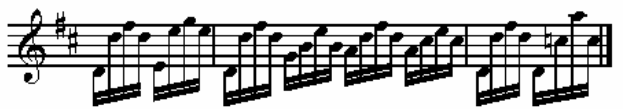

Accords à quatre cordes:
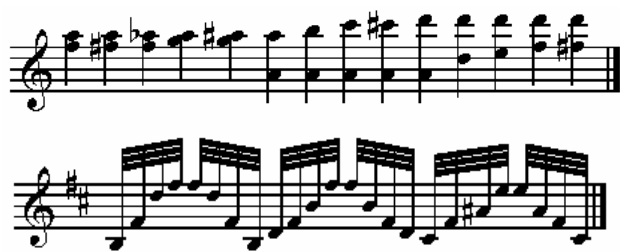

Suites d'accords, dans différens $[$ sic $]$ tons

qui peuvent s'employer tant en arpèges

qu'en cadences finales:

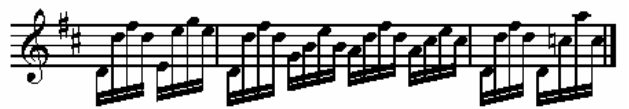

Four string chords:

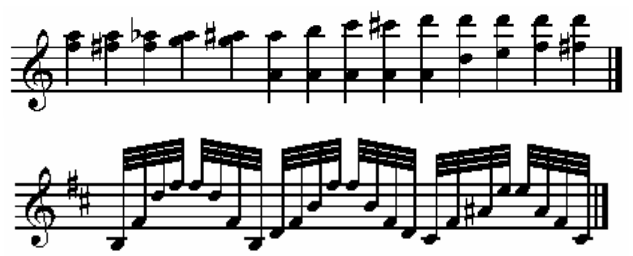

These are harmonic progressions, in different keys, which can be used in arpeggios as much as in final cadences:
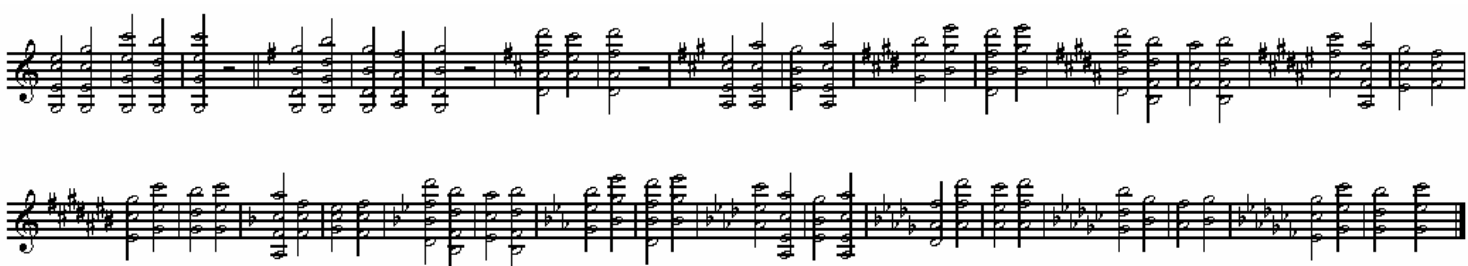

On peut partager tous ces accords en

doubles-cordes, en prenant les deux notes

supérieures pour une double-corde, les

deux du milieu pour une autre et les deux

inférieures pour une troisième, mais on ne

peut pas atteindre par exemple la $1^{\text {re }}$ et la

$3^{\text {me }}$ corde, sans toucher avec l'archet la $2^{\text {me }}$

qui se trouve entre; ne la $2^{\text {me }}$ et la $4^{\text {me }}$ sans

toucher la $3^{\text {me }}$ comme nous l'avons déjà dit en parlant des accords de trois ou quatre
All these harmonies can be divided into

double-stops by taking the two higher

notes as a double-stop, the two middle for another and the two lower for a third; but one cannot reach (for example) the first and third strings without touching the second, which is between, with the bow, nor the second and fourth without touching the third as already stated in the discussion on three and four-note chords. notes. 
Voici une série d'Exemples de doublescordes dont on peut se servir.

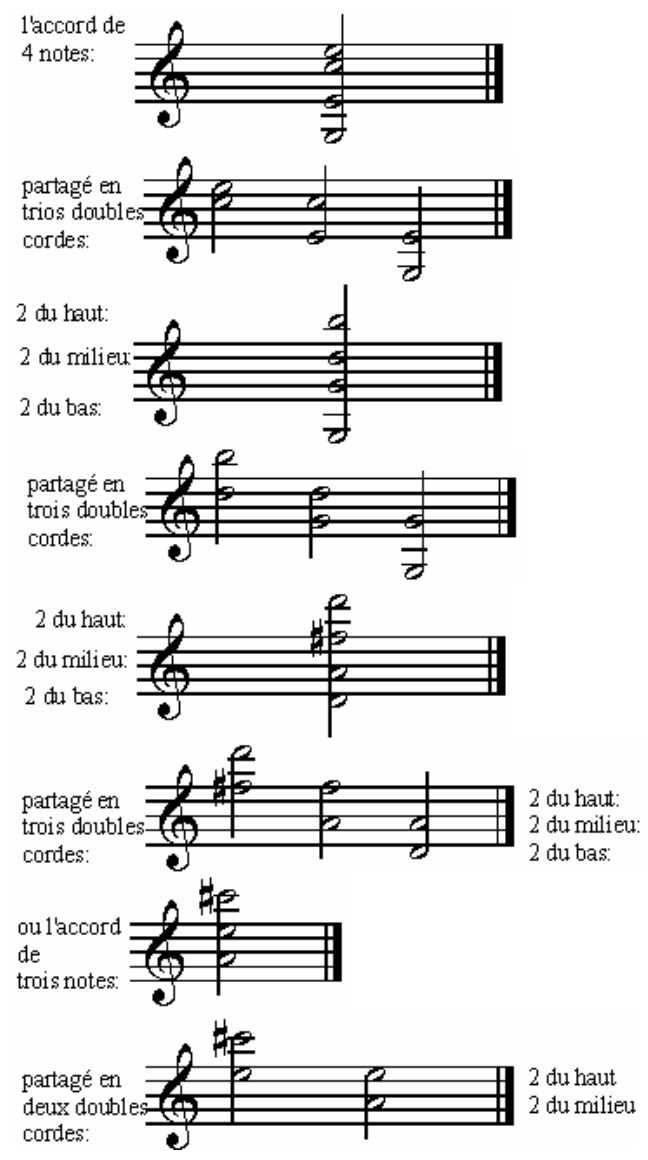

On donne très souvent au $2^{\text {me }}$ violon des

arpèges ou batteries dans les notes graves

qui produisent un très bon effet en

accompagnant un chant simple.

On obtient encore de beaux effets sans la musique d'ensemble par les unissons et les octaves;
Here is a series of examples of doublestops which can be useful.

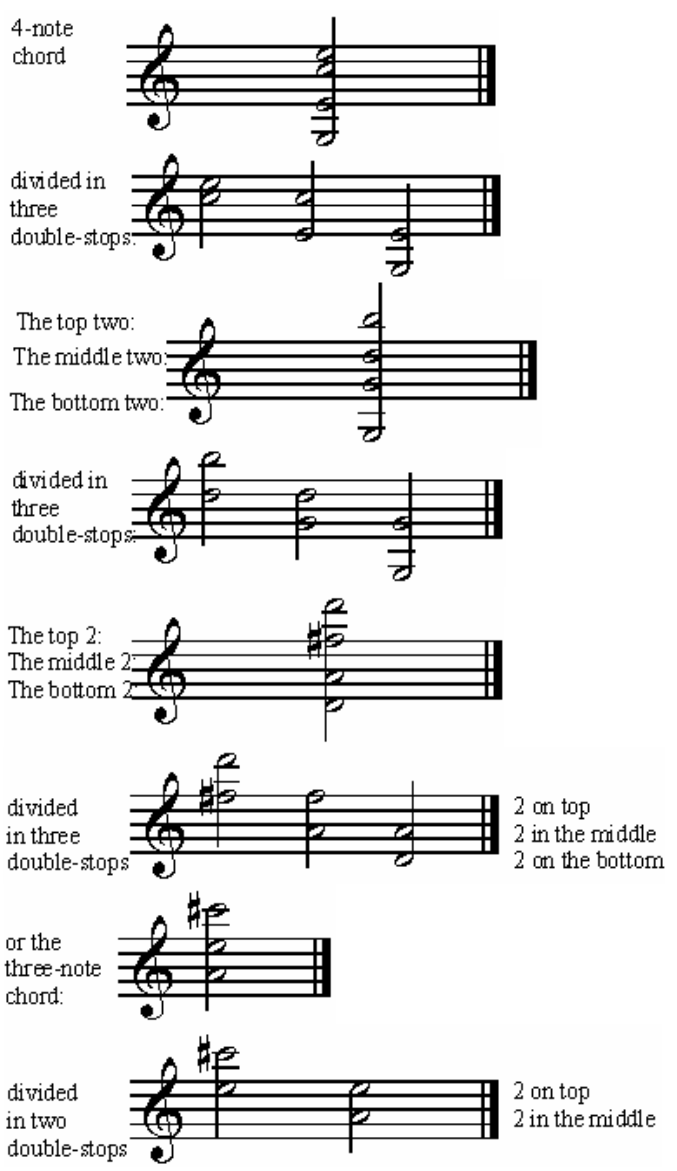

Quite often, the second violin is given some arpeggios or percussive effects in low notes, which produce a very good effect in the accompaniment of a simple song.

Beautiful effects are still obtained, without ensemble music, through the use of unisons and octaves: 


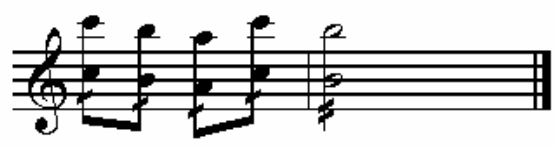

Mais il ne faut pas que le mouvement soit trop rapide, car de tels passages seraient rarement exécutés bien juste par beaucoup d'artistes à la fois.

De même, des figures dans le genre de celles qui suivent, sont d'une exécution assez difficile dans un mouvement rapide à cause du démanché de l'instrument, c'està-dire, parce que la main gauche est obligée de changer trop vite de place pour sauter sur les différentes positions. Le compositeur ne doit donc pas s'en servir habituellement dans l'orchestre, parceque données par beaucoup d'artistes à la fois, elles offriraient rarement un ensemble satisfaisant.
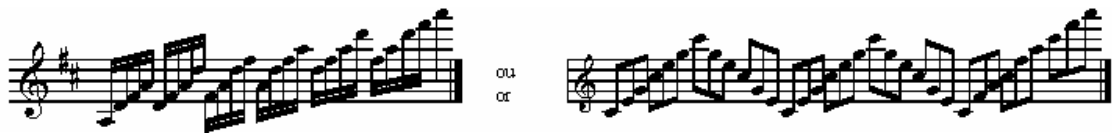
ou On produit encore différens effets sur le violon par:

$1^{\circ}$. La Sourdine, qui donne au violon

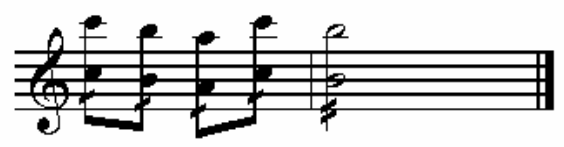

But the tempo cannot be too fast, because such passages would seldom be played well by many artists at the same time.

In the same way, figures such as the following are rather difficult to play in fast tempos because of the shifting of positions, in other words, because the left hand is obliged to change places too quickly to move to the various positions. Thus, the composer should not habitually use it in the orchestra, because many artists producing such figures at the same time would seldom produce a satisfactory ensemble. 
un timbre violé, mystérieux et plaintif; il est même nécessaire d'employer quelquefois la Sourdine, et c'est à tout qu'on croit y suppléer en jouant piano, parce que cela ne peut tenir lieu de son accent, mais il faut laisser aux artiste plusieurs mesures de pauses pour l'adapter au chevalet ou l'en ôter.

Un inconvénient de la Sourdine, c'est qu'elle dérange quelquefois l'accord du violon.

$2^{\circ}$. Le pizzicato, qu'on obtient en pinçant la corde avec un doigt de la main droite ou de la main gauche; on en fait sur une corde, en doubles-cordes, en accords, et aussi très souvent en arpèges.

Quelquefois un chœur de violons joue avec l'archet (col arco), tandis que les autres violons jouent pizzicato, ce qui fait très bon effet.

$3^{\circ}$. Sul ponticello: C'est une espèce de son qu'on obtient en approchant le plus possible l'archet du chevalet et ne le viola timbre, mysterious and plaintive; it is even necessary to use the mute sometimes; one considers the effect of playing piano a substitute for the mute, since it cannot maintain its accent, however one must give the artists several measures of rest so that they may add or remove the mute.

A disadvantage of the mute is that it sometimes disturbs the tuning of the violin.

2. The pizzicato is created by plucking the string with a finger of the right or left hand; it is sounded on a string, in doublestops, harmonies, and also very often in arpeggios.

Sometimes a chorus of violins plays with the bow (col arco) while the other violins play pizzicato, which produces a very good effect.

3. Sul ponticello. This is a type of sound which is obtained by placing the bow on the bridge as much as possible and 
promenant très légèrement sur les cordes. On n'emploie guère cet effet que dans les croches et doubles-croches;

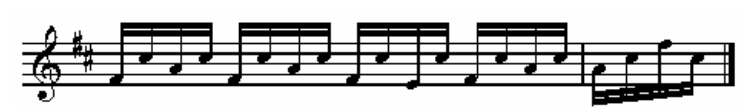

$4^{\mathrm{o}}$. Les sons harmoniques: ils sont doux et analogues à ceux du flageolet, (ce qui les a aussi fait nommer sons de flageolet.) On obtient ce genre de sons par un coup d'archet particulier et en posant légèrement les doigts sur certaines divisions de la corde. Ils sont fort différens pour le timbre et le ton de ceux qu'on produirait en appuyant le doigt tout-à-fait; par exemple, la corde $L a$ sur le point Ré de la $3^{\text {me }}$ petite octave, donne le $L a$ de la $4^{\text {me }}$ petite octave.

Exemples de sons harmoniques.

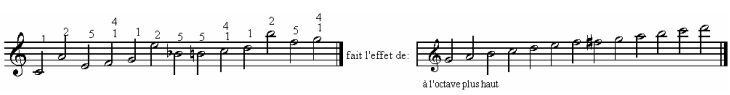

On désigne les sons harmoniques dans

l'orchestre, mais seulement dans les Solos, Concertos \&\&.

$5^{\circ}$. La Saccade est une secousse playing very lightly on the strings.

One hardly uses this effect except in the eighth notes and sixteenth notes;

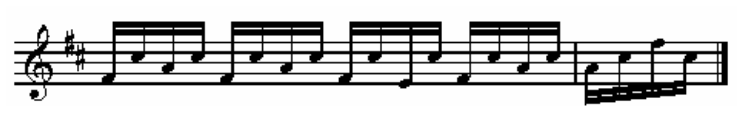

4. Harmonic sounds: they are soft and similar to those of the flageolet, (which also gave them the name sounds of flageolet). One obtains these kinds of sounds by a certain bow technique and by lightly placing the fingers on certain divisions of the string. They are very different in timbre and tone from those one would produce by pressing the finger down completely; for example, the D of the third small octave on the A string produces A of the fourth small octave. Examples of harmonics.

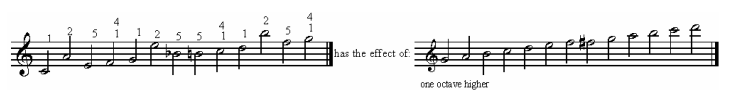

Harmonics are designated by the sign: o.

It must be observed that harmonics are never used in the orchestra, but only in solos, concertos, and the like. 
d'archet rude et prompte que l'on imprime aux notes généralement de $2^{\text {me }}$ en $2^{\text {me }}$ et $3^{\text {me }}$ en $3^{\text {me }} \&$ et quelquefois aussi irrégulièrement, c'est-à-dire sans symétrie;

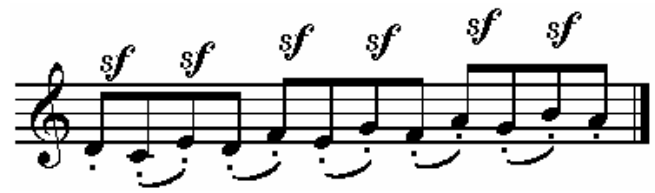

$6^{\circ} \quad$ Les sons ondulés: C'est un coup

d'archet qu'on indique par les signes

$$
\text { et qui consiste dans plusieurs sons }
$$

filés, dont on fait sentir le forté au commencement de chaque tems ou de chaque demi-tems de la mesure.

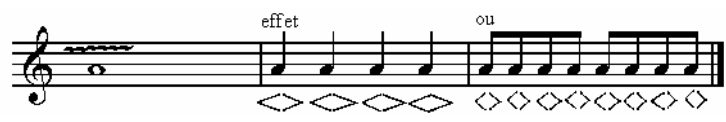

Le Staccato, le martelé, le détaché

$\& \&$. Tout le monde sait qu'on peut

employer chacun de ces effets avec

beaucoup d'avantage..$^{70,71}$

\section{LA VIOLE (Alto)}

Cet instrument est plus grand que le violon. Il s'écrit sur la clef d' $U t, 5^{\text {me }}$ ligne.
5. La Saccade is a hard and prompt jolt of

the bow which is generally written from

the second into second note and third into

third, and the like, and sometimes also

irregularly, in other words without

symmetry;

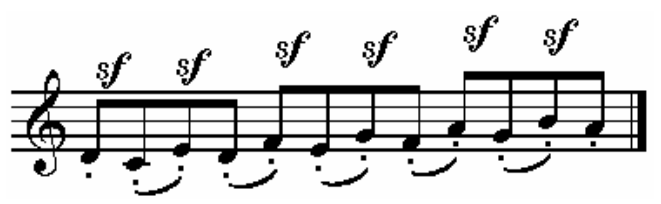

6. Vibrato. This is an effect obtained by

lightly striking with the bow; it is

indicated by the sign $\ldots$ and consists

of several drawn-out sounds, whose

loudness is felt at the beginning of each

beat or half beat of the measure.

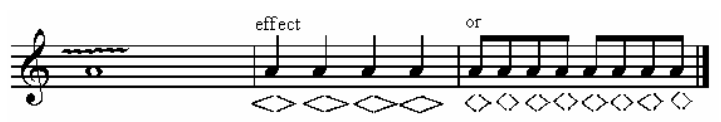

7. Staccato, martelé, détaché, et cetera.

Everyone knows that each one of these

effects can be used quite advantageously.

\section{The VIOLA (Viola)}

This instrument is larger than the violin.

It is written on the $\mathrm{C}$ clef, fifth line. 
Son étendue générale commence à l'Ut de la petite octave et va jusqu'au $L a$ de la $4^{\text {me }}$ petite octave:

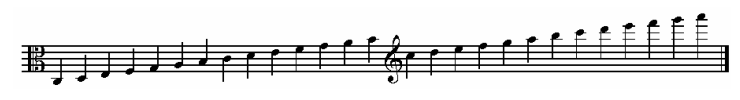

chromatiquement, mais l'étendue à

employer dans l'orchestre, est de l'Ut de la

petite octave au Sol de la $3^{\text {me }}$ petite octave.

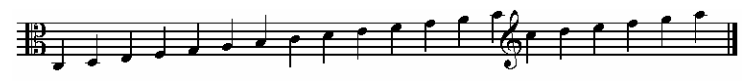

Les cordes de la viole sont une quinte plus basses que celles du violon; elles sont donc accordées en Ut, Sol Ré, La:

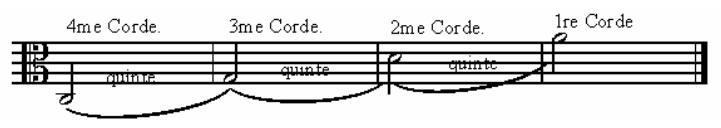

Le ton de cet instrument se distingue du violon par un caractère de mollesse et de langueur qui lui imprime un charme tout particulier.

Si la viole ne joue pas seule, elle tient toujours la parie de médium des violons; mais on l'emploie aussi très bien pour des Solos, Concertos, Variations, \&\&.

Quant à ce qui concerne la composition, les mêmes règles sont à observer que pour le
Its general range begins at the $\mathrm{C}$ of the small octave and goes to the A of the fourth small octave:

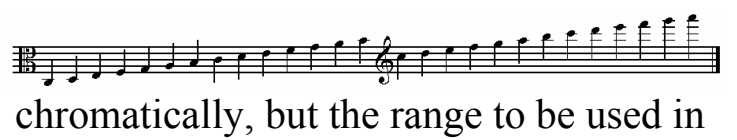

the orchestra is from $\mathrm{C}$ of the small octave to $G$ of the third small octave.

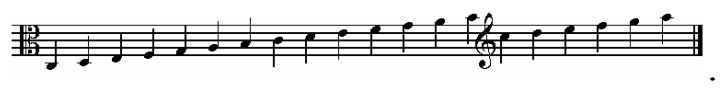

The strings of the viola are a fifth lower than those of the violin; they are thus tuned to $\mathrm{C}, \mathrm{G}, \mathrm{D}, \mathrm{A}$ :

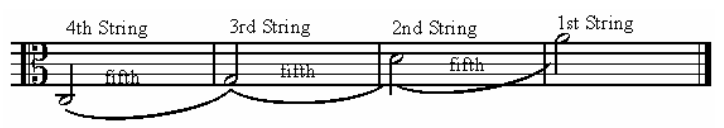

The tone of this instrument is

distinguished from the violin by a character of softness and languor, which gives it a very particular charm.

If the viola does not play alone, it always plays in the middle register of the violins; but it is also readily used in solos, concertos, variations, and the like.

As for composition, the same rules are to be observed as for the violin, which has 
violon, car cet instrument a le même

doigté, tant pour les doubles-cordes

naturelles ou altérées, que pour les arpèges,

trilles, \&\&.

Ce que nous avons dit pour la sourdine, le pizzicato, \&\& s'applique également à la viole et y produit aussi très bon effet.

Afin de rendre les passages plus pleins et plus nourris, on change très souvent les croches en doubles ou en triples croches; Exemple:

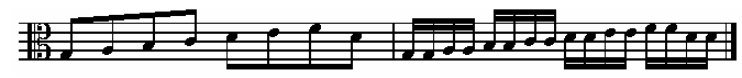

Mais il faut le faire avec discernement, car si le mouvement est très rapide, les croches font quelquefois plus d'effet que les doubles croches. Comme il y a ordinairement dans l'orchestre, moins de violes que de violons, et le ton en étant moins perçant, ou lui donne d'ordinaire les intervalles de l'accord qui doivent le moins ressortir; comme par exemple: La quinte de l'accord, la tierce de la basse, ou la quarte the same fingerings for natural or altered double-stops, as well as for arpeggios, trills, and so on.

What was said about the mute, the pizzicato, and the rest also applies to the viola, and also produces a very good effect.

In order to make the passages fuller and heartier, one very often changes the eighth notes into sixteenth or thirty-second notes; for example:

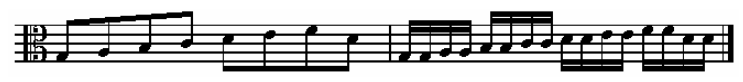

But it must be done with discernment, because if the tempo is very fast, eighth notes are sometimes more effective than sixteenth notes. As there are usually fewer violas than violins in the orchestra, and their tone less piercing, they are usually given the notes of the harmony which stand out the least; such as: the fifth of the chord, the third of the bass, or the higher fourth of the sixth chord, even 
supérieure de l'accord de sixte, quand bien même elle devrait jouer alors plus haut que le second violon, ce qui, du reste, arrive très fréquemment. La viole fait aussi souvent la basse dans les morceaux à trois parties, comme: $1^{\mathrm{er}}$ violon, second violon et viole, Elle produit quelquefois très bon effet en jouant la mélodie avec les violons, mais toutefois une octave plus bas; d'autres fois elle marche avec la basse à l'octave ou à l'unisson.

Dans l'orchestre, on écrit souvent pour la viole des passages qui semblent devoir être exécutés par deux instrumens, ce qui arrive aussi en effet; par exemple:

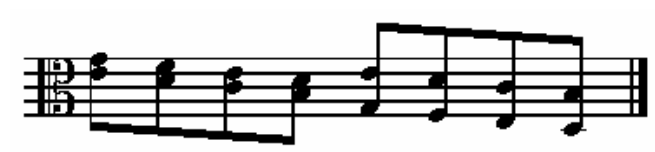

Dans de pareils passages, un artiste joue la partie supérieure et un autre la partie inférieure; c'est pourquoi il est inutile en écrivant d'observer si les doubles-cordes peuvent s'exécuter ou non par un seul instrument, parceque les artistes sont when they should then play higher than the second violin, which occurs quite frequently. The viola also often plays the lower part in the pieces with three parts. For example: first violin, second violin and viola. It sometimes produces a very good effect by playing the melody along with the violins, but, however, an octave lower; other times it plays with the bass an octave higher or in unison.

In the orchestra, viola passages are often written so that they seem to have to be played by two instruments, which also indeed occurs; for example:

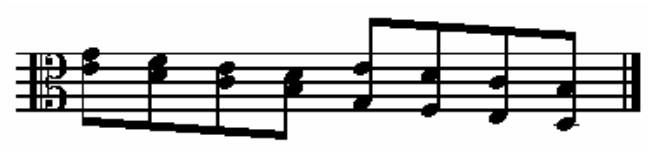

In similar passages, an artist plays the upper part and another, the lower part; this is why it is unnecessary, when composing, to observe whether or not double-stops can be played by a single instrument because the artists share those that would 
convenus de se partager celles qui seraient impraticables sur une seule viole. Ainsi des passages dans le genre du suivant, sont très communs; seulement il faut les barrer doublement de haut et du bas) afin de mieux les faire apercevoir.

Exemple:

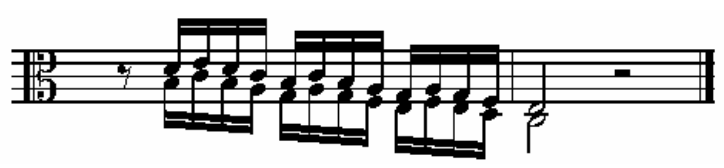

Dans quelques vieilles partitions on trouve des parties de seconde viole écrites sur la clef de ténor, les cordes étaient toujours: Ut, Sol, Ré, La.

Nous avons des Méthodes pour la viole de BRUM, CUPIS, GARAUDÉ, GERAUER, MARTINN, WOLDEMAR et autres. ${ }^{72}$

Il y avait encore jadis plusieurs autres espèces de violes qui sont presque toutes maintenant tombées en désuétude.

Et d'abord:

\section{LA VIOLA DE GAMBA}

Elle se nommait ainsi parcequ'on la tenait entre les genoux comme notre violoncelle. be impracticable on only one viola. Thus passages of the following type are very common; they must simply be doublebarred (top and bottom) so that they are clearly visible to the musician.

For example:

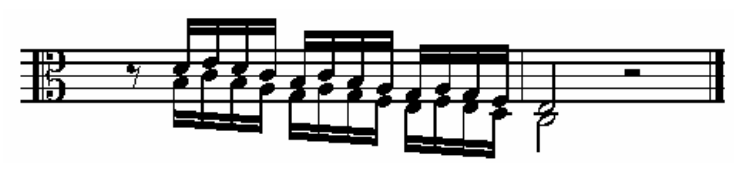

In a few old scores, second viola parts are found to be written on the tenor clef; the strings were always: C, G, D, A.

There are viola methods by BRUM, CUPIS, GARAUDÉ, GERAUER, MARTINN, WOLDEMAR and others. Formerly, there were several other types of violas which have almost all now fallen into disuse.

First:

VIOLA DA GAMBA

It was thus named because one held it between the knees, like our violoncello. 
Cette viole était autrefois un des instrumens les plus aimés; elle avait presque la forme du violoncelle qui lui a succédé, mais son timbre était moins perçant et se distinguait par une certaine aigreur qui n'était pas sans charme. Le manche était garni de degrés (comme celui de la guitare) qui indiquaient la place où devaient se poser les doigts.

D'abord elle n'eut guère que cinq cordes qui étaient en commençant par le haut: Ré, Sol de la $2^{\text {me }}$ petite octave; $L a, M i, U t$ de la petite octave, et $U t$ de la grande octave. Plus dard on alla jusqu'à six cordes qui étaient: Ré, Sol de la grande octave; $U t, M i$, $L a$ de la petite octave; et $R e ́$ de la $2^{\text {me }}$ petite octave; enfin, cers la fin du $17^{\text {me }}$ siècle, Marais, musicien de la chambre du Roi de France, y ajouta encore le même nom. $(\text { Gamba })^{73}$

\section{LA VIOLA BASTARDA}

C'est une espèce de viola di gamba plus ancienne que la précédente, et dont les six
This viola was at one time one of the most loved instruments. It nearly had the shape of the violoncello which succeeded it, but its timbre was less piercing and was characterized by a certain sharpness, which was not without charm. The neck had frets (like that of the guitar) that indicated the place where the fingers were to be placed.

Initially it had only five strings which were, starting with the top: D, G of the second small octave; A, E, C of the small octave, and $\mathrm{C}$ of the great octave. Later, it had six strings, which were: D, G of the great octave; $\mathrm{C}, \mathrm{E}$, of the small octave; and $\mathrm{D}$ of the second small octave; finally, towards the end of the 17th century, Marais, chamber musician for the King of France, gave it its name (Gamba).

\section{VIOLA BASTARDA}

This is a type of viola da gamba that is older than its predecessor, and whose six 
cordes étaient: $U t, F a$ de la grande octave; $U t, M i, L a$ de la petite octave; et Ré de la $2^{\text {me }}$ petite octave. Le corps de l'instrument étaient plus long et moins large que celui de la viola di gamba.

Il est à présumer qu'on lui donna le nom étrange de viola bastarda parcequ'on pouvait y exécuter les quatre espèces de voix comme aujourd'hui sur le violoncelle, et que par conséquent elle n'appartenait à aucune voix en particulier.

\section{LA TROMPETTE MARINE (instrument $\grave{a}$} corde)

On appelait aussi cet instrument trompetteviolon; son invention remonte à plus de deux cents ans, mais peu à peu on l'oublia comme complètement inutile; son nom vient de $\operatorname{marc}$ (mer) parcequ'on l'employait spécialement à bord des vaisseaux.

La trompette marine se compose de boîte en bois longue d'environ sept pieds large par le haut de six pouces et par le bas de strings were: $\mathrm{C}, \mathrm{F}$ of the great octave; $\mathrm{C}$, E, A of the small octave; and D of the second small octave. The body of the instrument was longer and less broad than that of the viola da gamba.

It is to be presumed that it was given the strange name of viola bastarda because one could play all four kinds of voices on it, as on today's modern violoncello, and that consequently it belonged to no voice in particular.

TRUMPET MARINE (string instrument)

This instrument is also called the trumpetviolin. Its invention goes back more than two hundred years, but little by little it was discarded, as it was completely useless. Its name comes from marc (sea) because it was usually played on board sea-going vessels.

The trumpet marine is consists of a wooden box, approximately seven feet long, six inches wide at the top, two 
deux pouces, le coffre ainsi disposé reste ouvert par derrière; le couvercle qui servait de table de résonance, était percé de plusieurs trous. A la partie inférieure était fixée une corde en boyau (assez semblable au Ré du violoncelle); cette corde posait sur un chevalet en forme de petit soulier; le talon de ce était encore fixée à la partie supérieure de l'instrument e telle sorte qu'en frôlant la corde avec l'archet on obtenait un ronflement. Pour jouer de la trompette marine, on posait à terre la partie inférieure et l'on appuyait la partie supérieure contre la poitrine, puis avec la main gauche on touchait tout légèrement la corde, (comme pour les sons harmoniques du violon) et par la on produisait des tons auxquels on voulait bien trouver quelque ressemblance avec ceux de la trompette sourdine.

\section{LA VIOLA POMPOSA}

Cet instrument fut invente par le célèbre Seb. BACH. inches wide at the back, the trunk thus arranged remains open at the back; the lid which was used as resonator, was bored with several holes. A catgut string was affixed to the lower part (rather similar to the D string of the violoncello); this string sat up on a bridge in the shape of a small shoe; its heel was affixed at the upper part of the instrument so that a tone was sounded by passing the bow over the string. To play the trumpet marine, one stood the lower part on the ground and supported the upper part against the chest, then with the left hand one very lightly touched the string, (as with the harmonics of the violin) and thereby one produced tones which easily resembled those of the muted trumpet.

\section{VIOLA POMPOSA}

This instrument was invented by the famous Johann Sebastian Bach. 
Il était plus grand et plus haut que la viole ordinaire et pourtant on le tenait dans la même position; outre les quatre cordes de la viole, il en avait encore une cinquième accordée en $M i$, et qu'on appelait aussi la quinte.

Le violoncelle s'étant peu à peu perfectionné et les artistes y gagnant de jour en jour, on oublia la voila pomposa d'autant plus facilement qu'elle était lourde et par cela même incommode à manier.

\section{LA VIOLE D'AMOUR}

Cet instrument doit son nom au ton doux et agréable que l'on en peut tirer. Il se tient dans la même position que la viole ordinaire. On ne l'employait jamais dans l'orchestre, mais seulement pour exécuter des solo, cantabile, adagio, $\& .^{74}$

Cet instrument est plus long et plus large que la viole; il avait sur le manche sept cordes en boyaux, dont les quatre ou cinq plus graves étaient recouvertes d'un fil
It was taller and higher than the ordinary viola, but it was held it in the same position as the viola; it had a fifth string in addition to the four strings of the viola, tuned to E, which was also called the fifth.

As the violoncello was being perfected little by little and the artists improving there day by day, the viola pomposa was all the more easily forgotten since it was heavy, and thus, inconvenient to manipulate.

\section{VIOLA D'AMORE}

This instrument owes its name to the soft and pleasant tone that it can produce. It is held in the same position as the ordinary viola. It was never used in orchestras, but only to play in solo, cantabile, adagio, and the like.

This instrument is longer and broader than the viola; it had on its neck seven gut strings on its neck; four or five of the lowest ones were covered with a wire; and 
métallique; et en dessous du chevalet et du manche était placé un pareil nombre de cordes en acier ou en cuivre jaune afin de donner au ton plus de force et d'intensité, ces cordes d'acier étaient ordinairement accordées à l'unisson des cordes de boyau, quelquefois aussi à l'octave.

Les cordes de la viole d'amour étaient accordées ou en Sol de la grande octave, $U t, M i, L a$ de la petite octave; Ré, Sol de la $2^{\text {me }}$ petite octave; et $U t$ de la $3^{\text {me }}$ petite octave. Ou bien en Sol de la grande octave; $U t, M i, L a$ de la petite octave; Ré, Sol de la $2^{\mathrm{me}}$ petite octave; et $R e ́$ de la $3^{\mathrm{me}}$ petite octave. Ou bien encore en $F a, L a$ de la petite octave; $U t, F a, L a$ de la $2^{\text {me }}$ petite octave; et $U t, M i, L a$ de la $3^{\text {me }}$ petite octave.

Plus tard on l'accorda en Ré, harmoniquement: les cordes étaient alors en $L a$ de la grande octave; $R e ́, L a$ de la petite octave, Ré, $F a \#, L a$ de la $2^{\text {me }}$ petite octave; et Ré de la $3^{\text {me }}$ petite octave; et il y a like number of steel or brass strings were placed below the bridge or the neck in order to give the tone more force and intensity. These steel strings were usually tuned in unison to the gut strings, or sometimes at the octave.

The strings of the viola d'amore were tuned to either $\mathrm{G}$ of the great octave, $\mathrm{C}$ and $\mathrm{E}$ of the small octave, D and $\mathrm{G}$ of the second small octave, and $\mathrm{C}$ of the third small octave; or they were tuned to $\mathrm{G}$ of the great octave, $\mathrm{C}$ and $\mathrm{E}$ of the small octave, D and G of the second small octave, and D of the third small octave; or even to $\mathrm{F}$ of the small octave, $\mathrm{C}$ and $\mathrm{F}$ of the second small octave, and $\mathrm{C}$ and $\mathrm{E}$ of the third small octave.

Later, it was tuned in D harmonically: the strings were then tuned to $\mathrm{A}$ of the great octave; D of the small octave, D and F\# of the second small octave; and D of the third small octave. There were artists 
avait des artistes qui, au lieu d'accorder les cordes d'acier à l'unisson ou à l'octave, les accordaient dans la gamme de Ré; c'est-àdire: Ré, Mi, Fa\#, Sol, La, Si, Ut\#.

De nos jours on écrit ordinairement la viole d'amour sur la clef de Fa, $4^{\text {me }}$ ligne, pour les tons graves, et sur la clef de Sol, $2^{\text {me }}$ ligne, pour les tons du médium et de l'aigu. Autrefois on l'écrivait sur la clef d'Ut, $3^{\text {me }}$ ligne, mais pourtant toujours sur la clef de Fa pour les tons les plus graves, toutefois une octave plus bas que maintenant. Les tons élevés produisaient au premier aspect un effet étrange, parceque, à commencer d'en haut, l'accord des deux premières petites cordes formait une quarte; celui de la $2^{\text {me }}$ et $3^{\text {me }}$ une tierce mineure, et enfin celui de la $3^{\text {me }}$ et $4^{\text {me }}$ une tierce majeure; cependant ces intervalles étaient représentés en notes comme si les cordes eussent été accordées par quintes. L'artiste était donc obligé de se figurer who, instead of tuning the steel strings to a unison or the octave, tuned them to the D scale; i.e.: D, E, F\#, G, A, B, C\#. Today, the viola d'amore is usually written on the bass clef for the low register tones, and on the treble clef for the tones of the medium and high registers.

Formerly, it was written on the third C clef line, but always on the bass clef for the lowest tones, which however was an octave lower than today. The high tones produced a strange effect upon first appearance, because, beginning with the top strings, the harmony of the first two small strings formed a fourth; that of the second and third a minor third, and finally that of the third and fourth a major third; however these intervals were represented in notes as if the strings had been tuned in fifths. Thus the artist was obliged to imagine that he was playing a 
qu'il avait un violon en main, pour les quatre cordes les plus hautes: Ré, $L a, F a \#$, Ré; et aussi pour tous les tons qu'on pouvait produire sur ces quatre cordes; par Exemple:
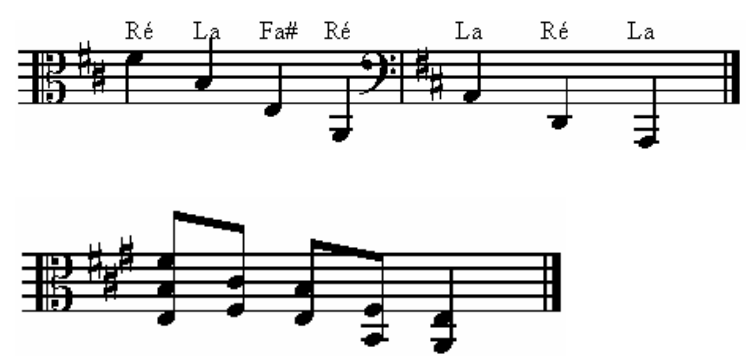

fait l'effet de:

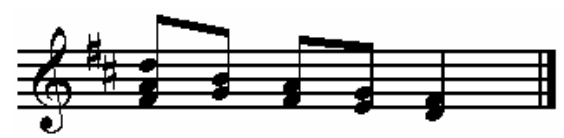

Ainsi, dans les morceaux en Ré majeur, avec cette manière d'écrire, à l'Ut\# et $F a \#$ on devait encore ajouter le $\mathrm{Sol} \#$; parceque, dans la marche de la tierce majeure: $R e ́, M i$, $F a \sharp$, ou plus haut encore, il fallait se figurer qu'on jouait: $M i, F a \sharp, S o l \#, \& \&$ ave la clef de Fa, on n'avait plus besoin d'écrire à la clef ce Sol\#.

Les compositeurs modernes emploient ordinairement la clef d'alto (Ut\# et Fa\#) seulement, jusqu'à la première petite corde violin, for the four highest strings: D, A, $\mathrm{F} \#, \mathrm{D}$ and also for all the tones which one could produce on these four strings; for example:
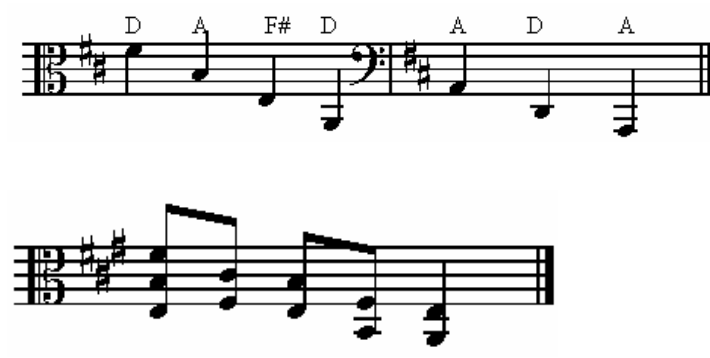

has the effect of:

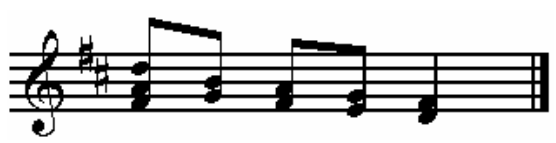

Thus, with this manner of writing, the pieces in $\mathrm{D}$ major with $\mathrm{C} \#$ and $\mathrm{F} \#$, a $\mathrm{G} \#$ still had to be added because in the scale up to the major third: D, E, F\#, or higher still, it was necessary to imagine that one was playing: $E, F \#, G \#$, et cetera in the bass clef. One did not need to write the note $\mathrm{G} \#$ anymore.

The modern composers usually use the alto clef $(\mathrm{C} \#$ and $\mathrm{F} \#)$ only, up to the first small string in D. In my opinion, this is 
en $R e ́$; ce m'est qu'à partir de là qu'ils se servent de la clef de Sol, $2^{\text {me }}$ ligne, pour les tons plus élevés et leurs doubles-cordes, et ils écrivent les tierces, quartes, quintes \&, justement comme ces intervalles frappant la vue et l'oreille.

Voici deux gammes comparées à une troisième, laquelle est écrite sur la clef de $F a, 4^{\text {me }}$ ligne, et la clef de $\operatorname{Sol} 2^{\text {me }}$ ligne: why they use the treble clef for the higher tones and their double-stops, and write the thirds, fourths, fifths \&, precisely as these intervals are read and sounded.

Here two scales are compared to a third, which is written on the bass clef and the treble clef:

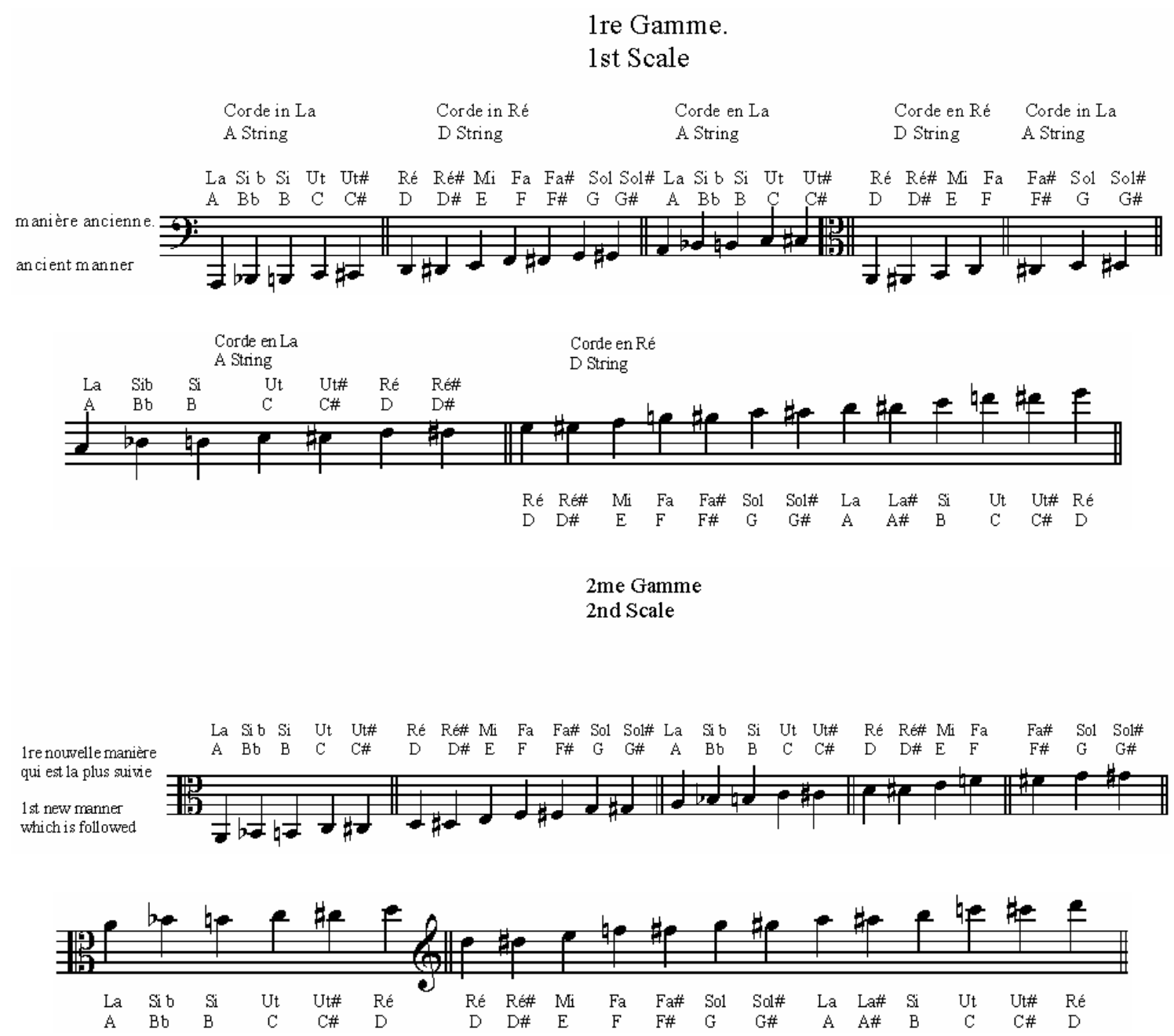




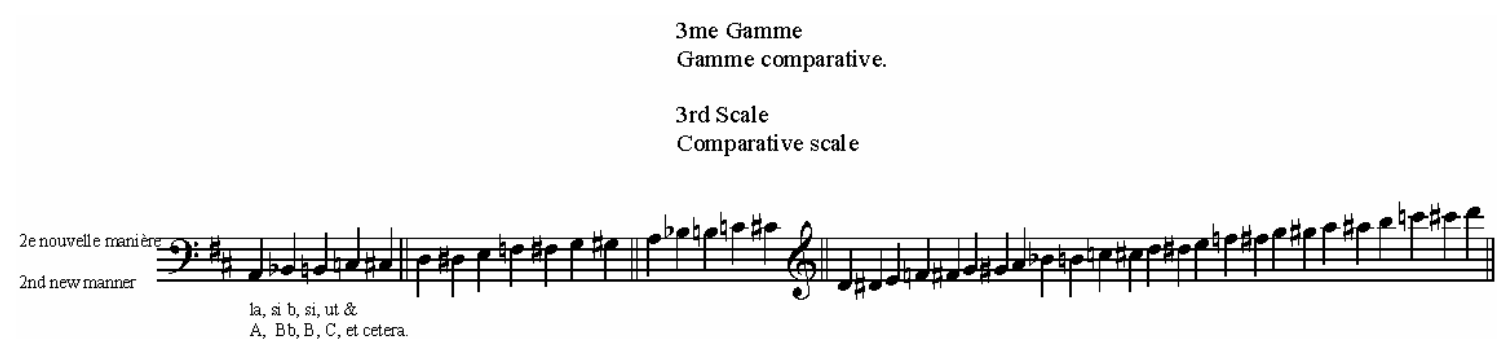

Nous avons de Mylandre une Méthode de voile d'amour.

Le violet anglais se distingue de la viole d'amour en ce qu'il n'a pas de $L a$ grave, et ainsi ne porte que six cordes au lieu de sept.

\section{VIOLA DI SPALA (viole d'épaule)}

On ne trouve nulle part la manière dont on accordait cet instrument; on raconte seulement qu'il était très recherché et qu'on s'en servait fort souvent pour accompagner, à cause de son ton perçant.

On le suspendait avec un ruban à l'épaule droite, ce qui lui a fait donner son nom. Il est à présumer que la viola di spala était à peu près notre violoncelle actuel, car on trouve encore des musiciens de village qui suspendent le violoncelle à l'épaule droite
There is a method for the viola d'amore by Mylandre.

The English violette is distinguished from the viola d'amore in that it does not have an $\mathrm{A}$ in the low register, and thus has only six strings instead of seven.

\section{VIOLA DA SPALLA (shoulder viola)}

There is no information on the way that this instrument was tuned; only that it was quite sought after and that it was very often used for accompaniment, because of its piercing tone.

It was suspended from the right shoulder with a ribbon, which gave the instrument its name. It is to be presumed that the viola da spalla was an approximate equivalent to our current violoncello, because one still finds village musicians 
avec une courroie, tandis que nos artistes le who suspend the violoncello from the tiennent entre les genoux.

right shoulder with a strap, whereas our

artists hold it between the knees.

\section{VIOLA BARDONE (ou baryton)}

VIOLA DI BARDONE (or baritone)

La viola bardone était encore un instrument The viola di bardone was another bass

de basse qui avait un ton agréable et se instrument which had a pleasant tone and

prêtait surtout à une expression douce et lent itself to an especially soft and

mélancolique, toutefois dans un melancholic expression - in slow tempos;

mouvement lent, car la manière de le traiter however, since the manner of treating the

offrait beaucoup de difficultés. instrument posed many difficulties.

Cet instrument avait la forme de la viola di This instrument had the shape of a viola

gamba et portait sept cordes à boyau que $\quad$ da gamba and had seven gut strings that

o'on touchait avec un archet, le plus were played with a bow, usually in

souvent en doubles-cordes. double-stops.

En dessous du chevalet et du manche, se There were sixteen to twenty steel strings

trouvaient seize à vingt cordes d'acier below the bridge and neck fixed with

fixées à des chevilles de cuivre jaune et brass pins, which were tuned with a key

qu'on accordait avec une clef comme celles like those of the harp.

de la harpe.

La manche ne touchait pas immédiatement

The neck did not directly touch the strings

aux cordes comme dans les autres

as in the other instruments of the same

instrumens de la même famille; il en était à family; it was at some distance from them, une certaine distance qui permettait au which made it possible for the left thumb 
pouce gauche d'appuyer en même tems sur les cordes d'acier. Au côte droit supérieur du couvercle se trouvaient encore quelques cordes métalliques de luth que l'on pinçait avec le petit doigt de la main droite, la quelle conduisait en même tems l'archet; ces cordes étaient destinées à produire un écho.

On appella aussi cet instrument: viola di fagotto à cause de son timbre ronflant. Ainsi qu'on le voit, il n'était possible d'y jouer que des morceaux expressément composes pour lui, et comme l'usage n'en était pas généralement répandu à cause des difficultés sans nombre qu'il présentait on le mit bientôt de côte, et peu à peu on l'oublia tout-à-fait.

On accordait les cordes supérieures de baryton en:

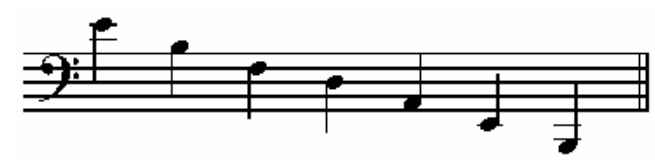

et les cordes inférieures en: to support the steel strings at the same time. At the right side above the lid were more metal lute strings which were gripped with the little finger of the right hand, which at same time led the bow; these strings were intended to produce an echo.

This instrument was also called: viola di fagotto, because of its bombastic timbre. Regarded thusly, it was only possible to play pieces expressly composed for it, and as its use was not generally widespread because of the countless difficulties that it presented, it was soon put aside, and little by little it was completely forgotten.

One tuned the higher strings of the baritone to:

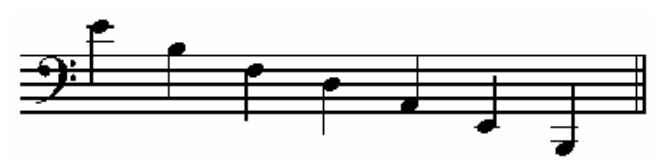

and the lower stings to: 


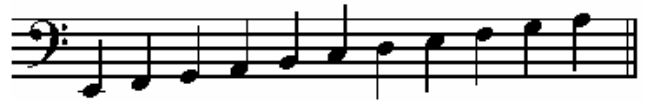

\section{LE VIOLONCELLE}

Le violoncelle est un des instrumens les plus indispensables de l'orchestre. ${ }^{75}$

La clef de $F a, 4^{\text {me }}$ ligne, lui est spécialement affectée; cependant les tons du médium s'écrivent sur la clef de ténor, $4^{\text {me }}$ ligne, et les tons élevés sur la clef de Sol, $2^{\text {me }}$ ligne.

Ses quatre cordes sont: $U t$, Sol de la grande octave; Ré et $L a$ de la petite octave on voit qu'elles ont disposées

Par quintes:

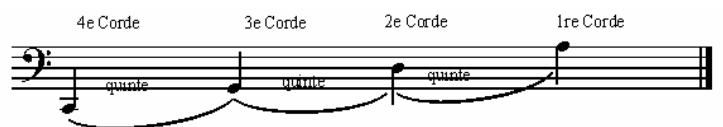

Ces cordes sont juste une octave plus bas

que celles de la viole.

L'étendue générale du violoncelle est:

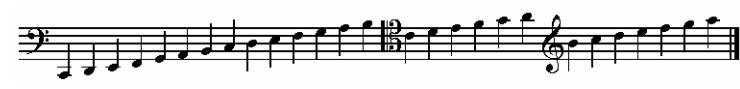

Chromatiquement

(Quelques compositeurs écrivent les notes

de la clef de Sol, une octave plus haut que

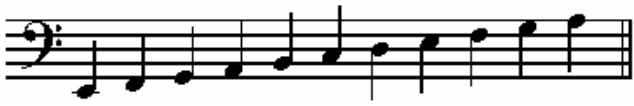

THE VIOLONCELLO

The violoncello is one of the most

essential instruments of the orchestra.

The bass clef is particularly affected by it;

however the middle tones are written in

the tenor clef and the high tones on the

treble clef.

Its four strings are: $\mathrm{C}$ and $\mathrm{G}$ of the great octave and D and A of the small octave.

One sees that they are arranged

By fifths:

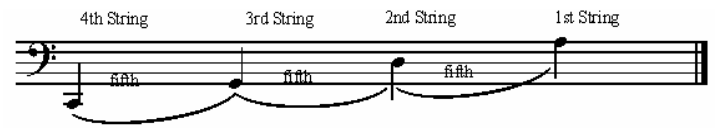

These strings are only an octave lower than those of the viola.

The general range of the violoncello is:

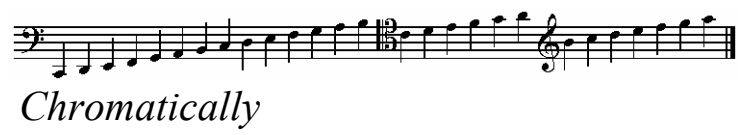

(Some composers write on the treble clef an octave higher than the produced effect, 
l'effet produit, par exemple $\mathrm{Sol}$ de la $3^{\text {me }}$

petite octave, fait l'effet et se joue comme

Sol de la $2^{\text {me }}$ petite octave.)

L'étendue à employer dans l'orchestre, va de l'Ut de la grande octave, jusqu'an $\mathrm{Sol}$ de la $2^{\text {me }}$ petite octave, tout au plus Si b (excepté toutefois dans un Solo important, où l'on écrit naturellement plus haut.)

Etendue pour l'orchestre:

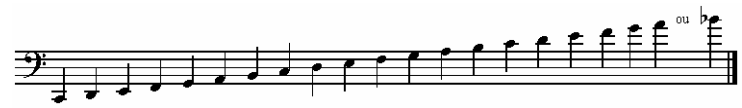

On emploie les tons les plus élevés du violoncelle le plus souvent quand il joue, tandis que la contrebasse se repose, ou quand il doit exécuter un Solo Cantabile d'un mouvement modéré, ou bien encore quand il marche à l'octave des violons, ce qui arrive quelquefois.

Ces tons élevés produisent en général beaucoup d'effet, parcequ'ils résonnent d'une manière perçante.

Souvent, afin de faire ressortir un passage avec plus de force on change aussi les for example $G$ of the third small octave is played like $G$ of the second small octave.)

The range to be used in the orchestra goes from $C$ of the great octave to $G$ of the second small octave-at most B b (except, however, in a significant solo, where one would naturally write higher).

Range for the orchestra:

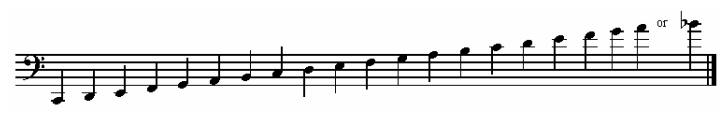

The highest notes are most often played on the violoncello while the double bass rests, or when it must play a cantabile solo of a moderato tempo, or even when it plays in octaves with the violins, which occurs occasionally.

In general, these high tones produce so much effect because they resonate in a piercing manner.

Often, in order to emphasize a passage with more force, one changes the eighth 
croches en doubles croches, ou les noires en croches; Exemple:

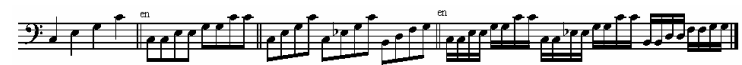

Quelquefois on donne au violoncelle des doubles-cordes:
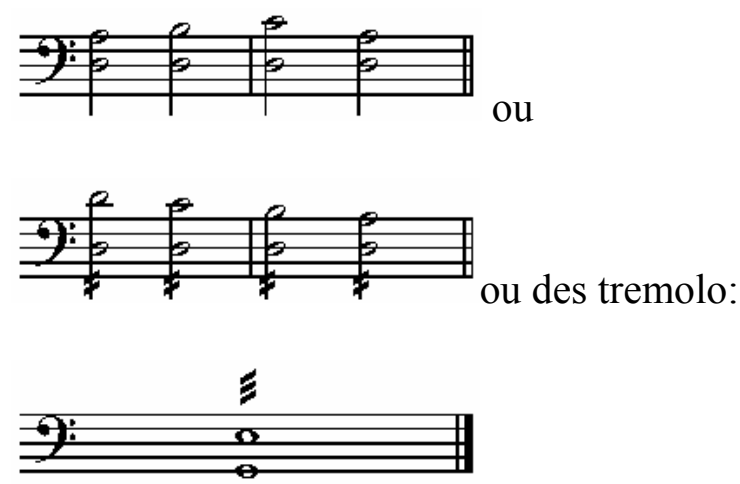

Qui peuvent s'exécuter très vite.

En général le tremolo est applicable à tous

les instrumens à cordes surtout sur une

simple corde, et autant que possible sur des cordes à vide.

On peut composer pour le violoncelle des passages tout aussi rapides que pour le violon, surtout quand il ne marche pas avec la contrebasse et qu'on lui donne une partie à part.

Les arpèges ou batteries sont très ordinaires notes into sixteenth notes, or the quarter notes to eighth notes; for example:

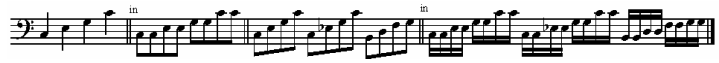

Sometimes the violoncello is given double-stops:
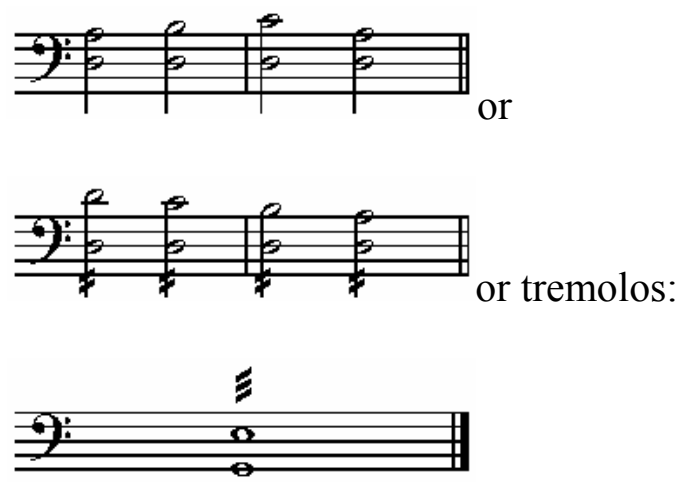

that can be played very quickly.

In general the tremolo is applicable to all the stringed instruments, especially on a single string, and as much as possible on open strings.

One can compose passages for the violoncello that are as fast-moving as passages written for the violin, especially when the violoncello is not playing with the double bass, and when one gives the violoncello its own part.

The arpeggios or percussive effects are 
sur cet instrument, et produisent un bon

effet si on n'en abuse pas.

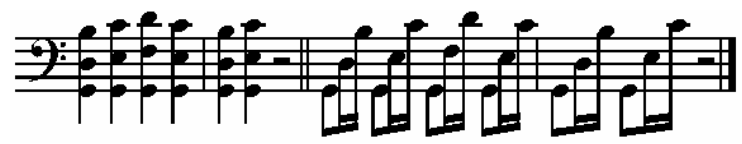

ou

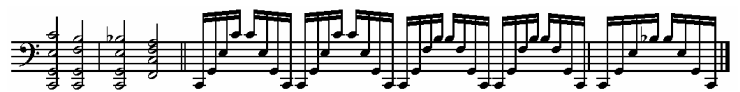

Dans le grand orchestre le violoncelle houe ordinairement la basse fondamentale avec la contrebasse et fait mieux ressortir cette dernière, parcequ'il donne tous les tons une octave plus haut, Si parfois le violoncelle s'écarte de cette règle pour faire un Solo, cela ne doit pas durer long-tems, parcequ'on remarquerait bientôt que la contrebasse houe seule.

Toutefois, dans certaines circonstances, on emploie chacun de ces deux instrumens d'une manière différente, et néanmoins avec beaucoup d'effet.

Plusieurs compositeurs introduisent dans l'orchestre 2, 3 et même 4 violoncelles; comme par exemple, Méhul dans l'ouverture de Joseph, et Rossini dans very common on this instrument, and produce a good effect, if not misused.

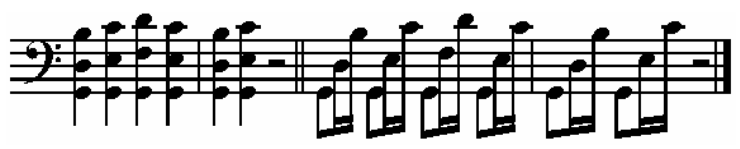

or

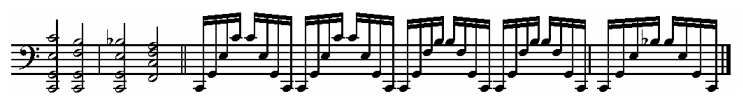

In the full orchestra, the violoncello usually plays the low fundamental tones with the double bass, which better emphasizes the double bass because the violoncello sounds an octave higher. If the violoncello sometimes deviates from this rule to play a solo, the solo should not last a long time, as one would soon notice that the double bass is playing alone.

However, in certain circumstances, each

of these two instruments is used

differently, and nevertheless with much effect.

Several composers introduce into the orchestra 2, 3 and even 4 violoncellos; for example, Méhul in the Overture to Joseph, and Rossini in the William Tell 
l'ouverture de Guillaume Tell.

Les trilles sont praticables sur tous les tons Trills and double-stops are feasible on all et même aussi les doubles-trilles, mais seulement dans les Solos, Concertos, \&.

Il ne faut pas écrire de passages qui descendent trop brusquement de l'aigu au grave, parceque, dans les démanchés, on est obligé de se servir du pouce comme d'un sillet mobile. On commence à employer le pouce au Ré sur la chanterelle; il est ordinairement nécessaire au Sol, ainsi qu'aux notes qui approchent du chevalet.

Plus on démanche, plus on est obligé de l'appuyer avec fermeté, à cause de l'élévation des cordes qui devient plus grande à mesure qu'on approche du chevalet.

On peut, sur le violoncelle, comme sur le violon, produire des sons harmoniques en approchant davantage l'archet du chevalet, et ne posant légèrement le doigt sur certaines divisions de la corde; ces sons, comme on l'a déjà dit, sont fort différens,
Overture. the tones, but only in solos, concertos, et cetera.

One must not write passages that change too abruptly from high to low, because, in shifting passages, one is obliged to use the thumb as a mobile fret. One begins to use the thumb at $D$ on the chanterelle string; it is usually necessary at $G$, as well as at those notes which approach the bridge. The more one shifts, the more one is obliged to press firmly, and because of the elevation of the strings, which becomes larger as one approaches the bridge.

On the violoncello, as on the violin, one can produce harmonic sounds by placing the bow closer to the bridge, and slightly pressing the finger on certain sections of the string. These sounds, as previously stated, are much different in the timbre 
pour le timbre et le ton, de ce qu'ils seraient si l'on appuyait tout-à-fait le doig par exemple, les sons donnent la quinte quand ils donneraient la tierce; la tierce quand ils donneraient la sixte, \&. On les désigne par $\circ$; d'ailleurs, on ne peut les employer que pour des Solos ou Concertos.

and pitch compared to what they would be

if on pressed down on the string completely. For example, the sounds produced when pressing down only slightly on the string would form the fifth, rather than the third (pressing down completely); likewise the third would be produced rather than the sixth, and so on. They are indicated by $\circ$; moreover, they can be used only in solos or concertos.

Quant aux effets du pizzicato, sul ponticello, sourdine, staccato, sons ondulés, détachés, \& on les emploie pour le violoncelle comme pour le violon.

\section{LA CONTREBASSE (Contra-Violon)}

Cet instrument s'écrivait sur la clef de $F a$, $4^{\mathrm{me}}$ ligne; l'étendue générale est:

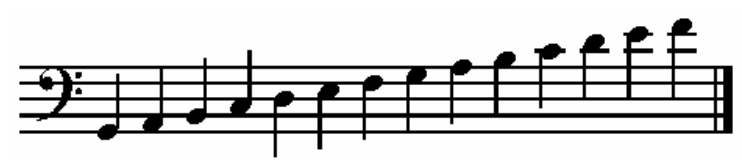

\section{Chromat.}

Naturellement les tons de la contrebasse se trouvent une octave plus bas qu'ils ne sont
As for the effects of the pizzicato, sul

ponticello, mute, vibrato, staccato

passage, détaché, et cetera: one uses them for the violoncello as one would for the violin.

\section{THE DOUBLE BASS (Counter-Violin)}

This instrument was written on the bass clef; the general range is:

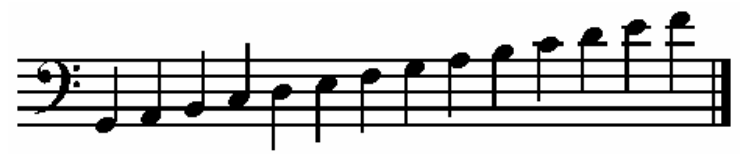

chromatically.

Naturally the sound of the double bass is an octave lower than is indicated by the 
indiqués par les notes.

Il y a trois espèces de contrebasses.

La première qui est la plus usitée en France et en Italie, a trois cordes qui sont:

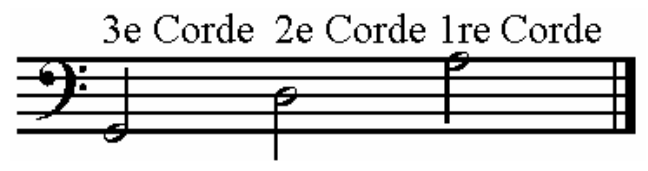

effet:

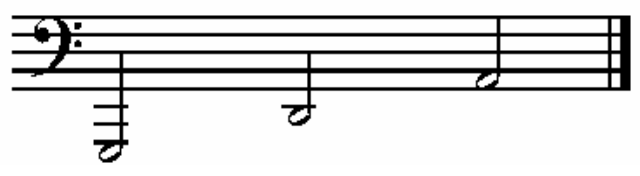

En Allemagne on accorde aussi ces trois cordes comme suit:

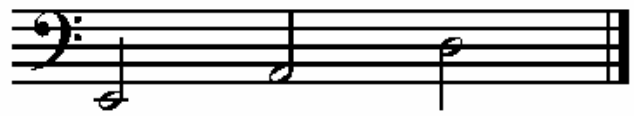

effet:

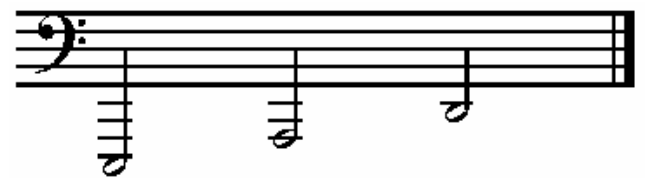

La deuxième est la contrebasse à quarte cordes qu'on a presque généralement adoptée en Allemagne. C'est la plus convenable et il serait à désirer qu'on l'introduisit partout. Ses cordes sont ordinairement accordées en notes.

There are three types of double basses.

The first, which is most used in France and Italy, has three strings which are:

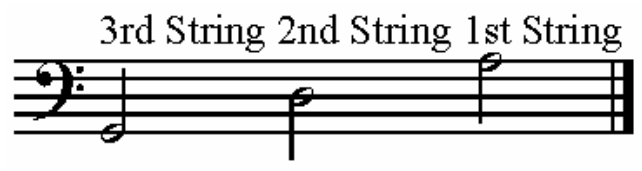

sounding:

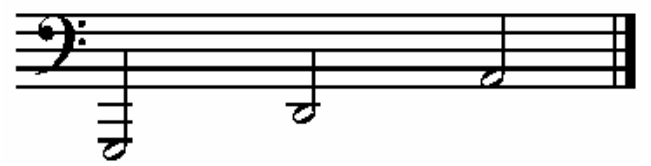

In Germany, it also has three strings, as follows:

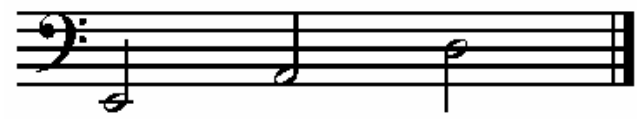

sounding:

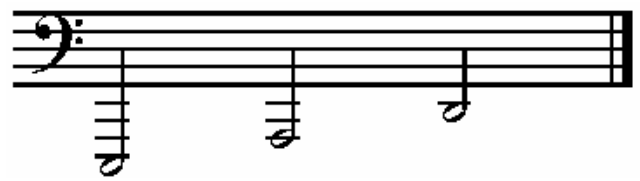

The second is the double bass with four strings, which has generally been adopted in Germany. It is the most suitable, and it would be desirable to have it introduced everywhere.

Its strings are usually tuned to $E, A, D, G$. 
$M i, L a, R e ́$,

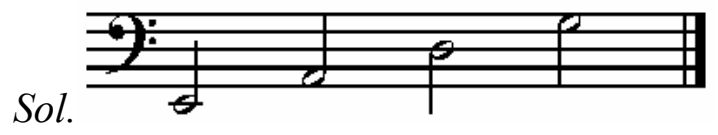

l'effet on est d'une octave plus bas, comme nous l'avons déjà dit.

Son étendue générale est:

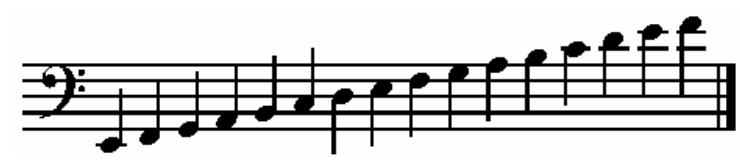

\section{Chromat.}

On accorde aussi quelquefois la contrebasse à quatre cordes en $\mathrm{Mi}$ ou $\mathrm{Fa}$,

La Ré, Sol; et même on commence à accorder le contre- $M i$ un ton plus bas, afin d'avoir le contre-Ré et le contre-Mib qui paraissent si souvent.

La troisième espèce est la contrebasse à cinq cordes qu'on emploie aussi en Allemagne (mais plus rarement;) elle s'accorde ordinairement en Fa, La, Ré, $F a \#, L a:$

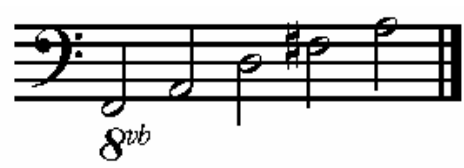

Son étendue générale est:

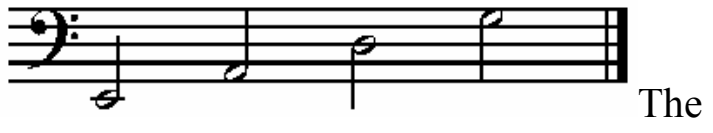

effect is an octave lower, as already

stated.

Its general range is:

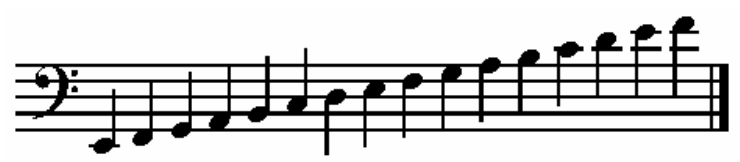

chromatically.

Also sometimes one tunes the double bass

of four strings to $E$ or $F, A, D$, $G$; and it

has even begun to be tuned to contra- $E$, a tone lower, in order to have contra-D and contra-E $b$ which appear so often.

The third type is the double bass with five strings which one also uses in Germany (but more rarely); it usually is tuned to $F$, $A, D, F \#, A$ :

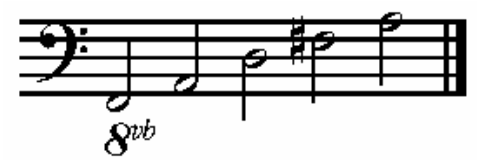

Its general range is: 


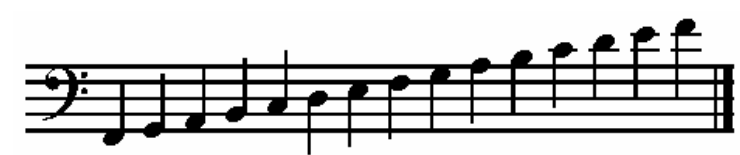

La contrebasse est un instrument

indispensable dans l'orchestre, car son

timbre profond et ronflant soutient

puissamment la basse fondamentale, et

donne à l'ensemble beaucoup de rondeur

et de plénitude.

Il ne faut se servir ni des tons les plus

graves, ni des plus élevés, parceque les

premiers résonnent confusément et que les derniers sont d'une exécution difficile.

Des passages prolongés dans un

mouvement rapide de beaucoup de notes

éloignées l'une de l'autre produisent

rarement bon effet.

Des figures dont les notes se suivent

diatoniquement, ou par répétition du même

ton, n'offrent pas de grandes difficultés;

mais cependant on préfère les laisser au

violoncelle et ne donner à la contrebasse

que les simples notes de la basse

fondamentale qu'elle rend avec beaucoup

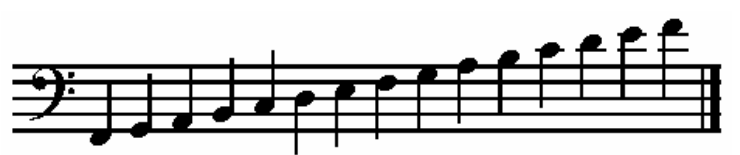

The double bass is an essential instrument

in the orchestra, because its deep and

bombastic timbre strongly supports the

low fundamental, and gives the ensemble

a very full and round effect.

One should use neither the lowest nor the

highest tones, because the former resound

too weakly and the latter are difficult to

play.

Prolonged passages with many notes that are distant from one another seldom

produce a good effect.

Figures whose notes follow one another diatonically, or by repetition of the same tone, do not cause great difficulties; however it is preferred to leave them in the violoncello part and to only give the double bass simple notes of the low fundamental bass, which are performed 
de force.

La plupart du tems, la contrebasse joue avec le violoncelle une seule et même partie; il faut seulement observer, que d'après son étendue indiquée ci-dessus, la contrebasse ne peut pas donner le contre$U t$, ou autrement dit, l'Ut de la grande octave du violoncelle, une octave plus bas; car la contrebasse à 3 cordes ne descend que jusqu'au Sol et celle à 4 cordes jusqu'au $\mathrm{Fa}$ ou $\mathrm{Mi}$.

Les artistes remplacent ordinairement cette note par celle correspondante à l'octave supérieure et qui ainsi se trouve à l'unisson avec le violoncelle' mais il arrive parfois que cette ressource est insuffisante; dans ce cas il vaut mieux écrive, pendant quelques mesures, une partie à part pour la contrebasse, ce qui devient tout-à-fait indispensable, par exemple si le violoncelle exécute des figures très rapides ou des sauts dont l'exécution est presque impossible sur la contrebasse. with much force.

Most of the time, the double bass and the violoncello play the same part together; it should be observed that, according to its range indicated above, the double bass cannot play contra- $C$ (otherwise known as $C$ of the violoncello's great octave, which is an octave lower) because the threestringed double bass can only play as low as $G$; the 4-stringed double bass, only as low as $F$ or $E$.

Artists usually replace this note with one an octave higher, which is thus in unison with the violoncello. However, sometimes this technique is inadequate; in this case it is better to write a separate part of several measures' length for the double bass such a technique becomes absolutely essential if the violoncello plays very fast figures or jumps whose execution is almost impossible on the double bass. 
Autant que possible, écrit les deux

instrumens sur une même portée, par

exemple:

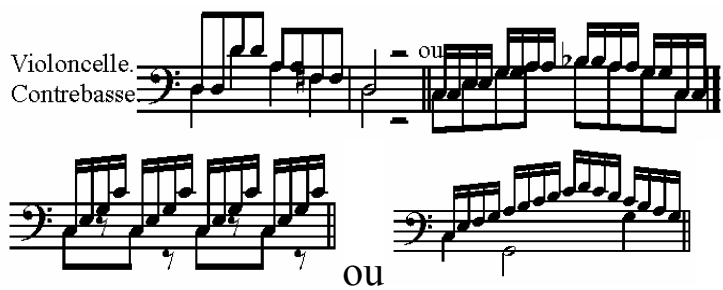

Si cela ne peut se faire, on prend deux

portées l'une au dessus de l'autre, que l'on

joint par une accolade, par exemple:

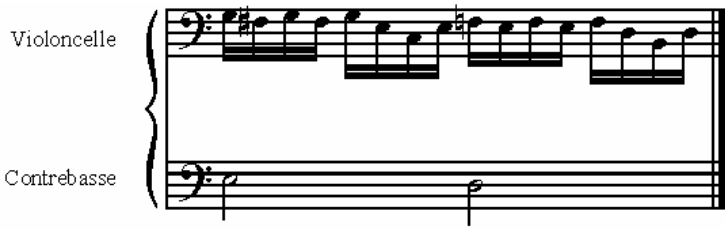

Dans l'exemple ci-dessus, le violoncelle a

l'air de marcher plus bas que la

contrebasse, mais il faut se rappeler que, la

contrebasse, mais il faut se rappeler que

dans la partie de contrebasse, le $M i$ qui est

écrit comme $M i$ de la petite octave, fait

l'effet de $M i$ de la grande octave, \&.

Dans de pareils passages il faut avoir soin

de ne pas écrire trop bas la partie de

contrebasse, parceque les tons graves
As much as possible, both instruments are

written in the same range, for example:

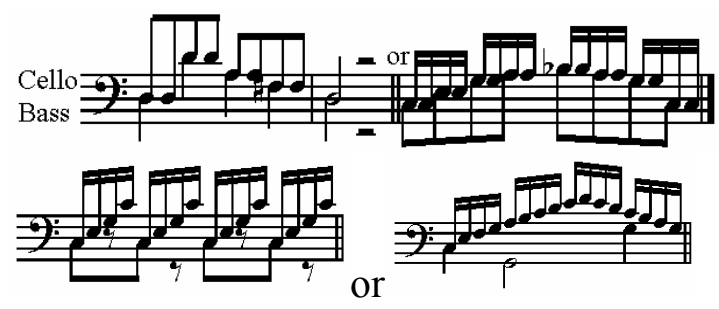

If that cannot be done, one writes two

staves, one on the top of the other, which

is joined by a bracket, for example:

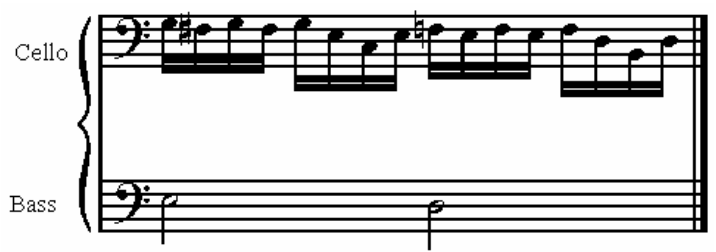

In the example above, the violoncello

seems to go lower than the double bass,

but it should be remembered that in the

double bass' part the $\mathrm{E}$ that is written as $E$

of the small octave produces the effect of

E of the great octave, et cetera.

In similar passages it is necessary to take

care to not write the double bass's part too

low, because the low registers would 
sembleraient bien confus n'étant plus

soutenus à l'octave par le violoncelle.

Sur la contrebasse on n'emploie ni les doubles-cordes, ni la sourdine; mais on se sert très souvent du pizzicato qui fait très bon effet; les trilles sont assez rarement usités.

Quelques artistes distingués font aussi sur cet instrument des sons harmoniques (de flageolet) qui, donnés avec précaution, ne sont pas sans un certain charme, nais bien entendu, ceci n'a lieu que dans des concertos.

Dans le quatuor: $1^{\mathrm{er}}$ violon, $2^{\mathrm{me}}$ violon, alto et violoncelle, la contrebasse forme la cinquième partie nécessaire.

C'est en général ce quatuor qui doit jouer dans l'orchestre le rôle le plus important, car les instrumens à vent et surtout ceux en cuivre employés trop fréquemment, perdent beaucoup de leur effet qui est si expressif sound quite confused if they were no longer sustained in the octave by the violoncello.

The double bass uses neither double-stops nor the mute; but often uses the pizzicato which is very effective; trills are rather seldom used.

Some distinguished artists also play harmonic (flageolet) sounds on this instrument which, written cautiously, are not without a certain charm, but of course this occurs only in concertos.

The quartet is usually composed of first violin, second violin, viola and violoncello, however, if necessary, the double bass forms the fifth part. In general this quartet must play the predominate role in the orchestra, because when one uses wind instruments-and especially brass instruments-too frequently, they lose much of their effect, 
quand on sait en user avec ménagement. ${ }^{76}$

77

\section{LA GUITARE}

On écrit cet instrument sur la clef de Sol,

$2^{\text {me }}$ ligne; son étendue générale va du $M i$ de

la grande octave jusqu'au $M i$ de la $3^{\text {me }}$

petite octave, mais comme les notes sont

écrites une octave plus haut que l'effet

produit, l'étendue écrite sur la clef de Sol

d'après laquelle on joue cet instrument est:

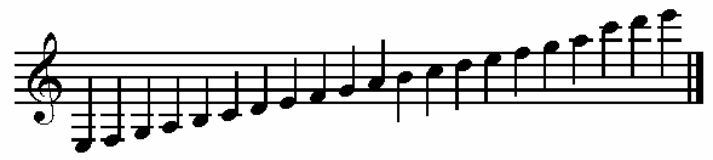

Chromatiquement.

Les six cordes de la guitare sont disposées de la manière suivante: $M i, L a, R e ́, S o l, S i$, $M i$; ce dernier $M i$ est de deux octaves plus haut que le premier.

Comme nous venons de le dire, chacune de ces cordes résonne une octave plus bas que la note écrite:

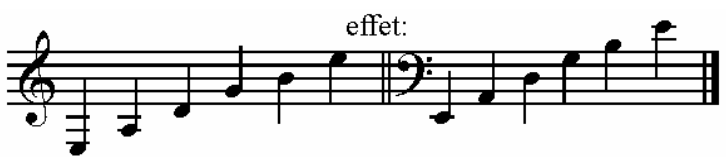

Il faut surtout pour la guitare s'efforcer which is so expressive when one employs it with care.

\section{THE GUITAR}

One writes this instrument on the treble

clef; its general range goes from $\mathrm{E}$ of the great octave to $\mathrm{E}$ of the third small octave, but since the notes are written an octave higher than the produced effect, the range written on the treble clef according to which one plays this instrument is:

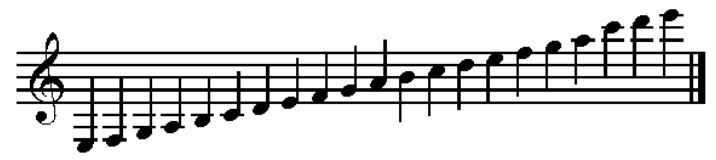

Chromatically.

The six strings of the guitar are arranged in the following way: $E, A, D, G, B, E$; this last $\mathrm{E}$ is two octaves higher than the first.

As we have just stated, each one of these strings sounds an octave lower than the written note:

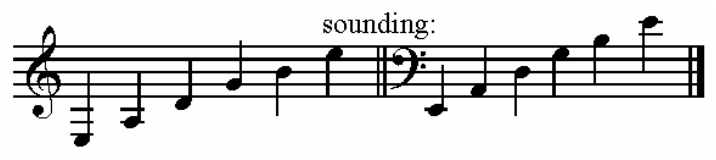

With the guitar it is especially important 
d'employer autant que possible les cordes à to endeavor to use the open strings as vide; car, bien qu'on puisse donner dans much as possible; because, although one son étendue tous les tons et demi-tons, il can sound all of the tones and semitones n'est pourtant pas permis de le faire tout-à- in its range, it is however not permitted to fait arbitrairement, surtout dans les accords, do so completely arbitrarily, especially in la partie de guitare consistant pour la the harmonies: the part of guitar consists, plupart, en accords, arpèges et autres for the most part, of harmonies, arpeggios figures d'accompagnement. and other figures of accompaniment. Dans les exemples suivans, les notes sont In the following examples, the notes are disposées de la manière la plus arranged in the manner most generally généralement usitée pour cet instrument. used for this instrument.

Les tons favorables de la guitare, sont: $U t \quad$ The guitar's most favorable keys are: $C$ majeur, Sol majeur, Ré majeur, La majeur, $\quad$ Major, G Major, D major, E major, F $\mathrm{Mi}$ majeur, $\mathrm{Fa}$ majeur, et leurs tons relatifs major, and their relative minor keys. mineurs. ${ }^{78}$

Le manche de la guitare est divisé en degrés dont chacun, en raccourcissant la corde, la hausse d'un demi-ton. Deux de ces degrés font un ton; trois font un ton et demi, et ainsi de suite.

Comme tous les tons de accords, arpèges, et en général de tous les passages rapides, s'obtiennent sur la manche, il faut observer
The neck of the guitar is divided into frets; each fret raises the pitch a semitone by shortening the string. Two of these frets make a whole step; three make a step and half, and so on.

Since all chords, arpeggios and fast passages are in general sounded by the frets on the neck, it should be observed 
que les doigts ne peuvent embrasser que trois et tout au plus quatre degrés, ce qui fait an plus un intervalle de deux tons; voici un exemple qui rendra cette remarque plus sensible:

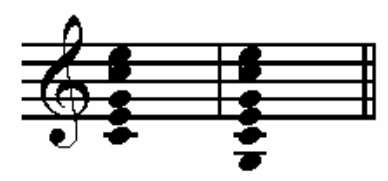

Pour pouvoir donner cet accord d' $U t$, il faut poser les doigts sur les degrés suivans: pour l'Ut inférieur, sur le $3^{\text {me }}$ degré de la corde $L a$; pour le $M i$ inférieur, sur le $2^{\text {me }}$ degré de la corde Ré; pour le $S o l$ il ne faut pas de doigt, parceque la corde à vide le donne naturellement; pour l'Ut du médium, sur le $1^{\text {er }}$ degré de la corde $\mathrm{Si}$; enfin pour le $\mathrm{Mi}$ aigu il ne faut pas de doigt, parceque la corde la plus haut est accordée dans ce ton.

Dans le second accord, le $M i$ grave se trouve la corde la plus grave à vide, et les doigts se poseront sur le $1^{\text {er }}, 2^{\text {me }}$, et $3^{\text {me }}$ degré, ce qui peut très bien s'exécuter; mais il faut prendre garde d'exiger, par exemple: le premier degré pour une corde et le that the fingers can reach only three or at most four scales, which produces at most a second interval; here is an example which will clarify this remark:

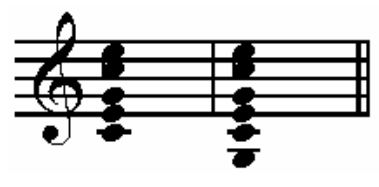

To be able to play this $\mathrm{C}$ chord, it is necessary to place the fingers on the following frets: for lower C: the third fret of the A string; for lower E: the second fret of the $\mathrm{D}$ string; for $\mathrm{G}$ it is not necessary to use a fret, because the open string produces it naturally; for middle $\mathrm{C}$ : the first fret of the $B$ string; and finally for high $\mathrm{E}$ it is not necessary to use a fret, because the highest string is tuned to this note.

In the second chord, low register $E$ is the lowest open string, and the fingers will be placed on the first, second, and third frets.

This chord is quite easily produced, but one must take care to require that (for example): the first fret is used for one 
sixième pour une autre. Voici encore quelques exemple précédés par des chiffres qui indiquent les degrés, te par des zéros qui indiquent les cordes à vide:

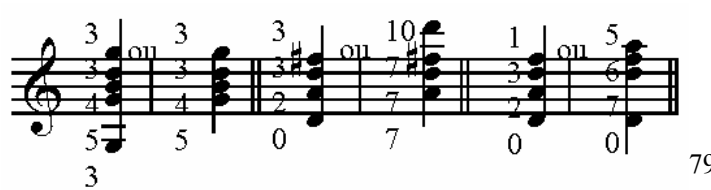

Les compositeurs qui ne jouent pas euxmêmes de la guitare et qui ne sont pas à même de consulter un artiste versé dans cet instrument, doivent calculer avec le plus grand soin, les tons qui forment les accords.

On peut exécuter sur la guitare presque toutes les figures, mais toutefois dans un mouvement modéré; néanmoins celles en forme d'accords brisés et qui ne modulent pas trop sont les meilleures.

Comme le jeu de la guitare ainsi que celui de la harpe n'est qu'un pizzicato continuel, on ne peut pas exiger de notes tenues dur cet instrument, mais en brisant les accords, on peut assez convenablement remplir string and the sixth for another. Here are more examples, preceded by numbers that indicate the fret, and zeros that indicate the open strings:

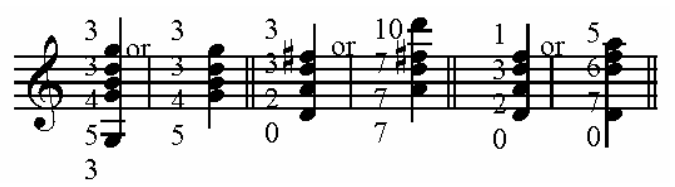

The composers who do not play the guitar themselves and who are not able to consult an artist, must take great care in calculating the notes that form the chords.

Almost all figures can be played on the guitar, but, however, in a moderate movement; nevertheless, it is best to use those figures formed by arpeggios, and which do not modulate too much.

Since the playing of the guitar, as well as the harp, is simply a continual pizzicato, one cannot require any sustained notes on this instrument, but by arpeggiating one can rather suitably fill a whole measure; in 
toute une mesure; dans ce cas il faut se

servir de la même désignation que pour la

harpe.

Pour la commodité des jeunes

compositeurs qui ne connaissent pas la

guitare, j’ai placé ici les cadences finales de

plusieurs tons majeurs et mineurs. this case it is necessary to use the same

designation as that of the harp.

For the convenience of the young

composers who don't know the guitar, I
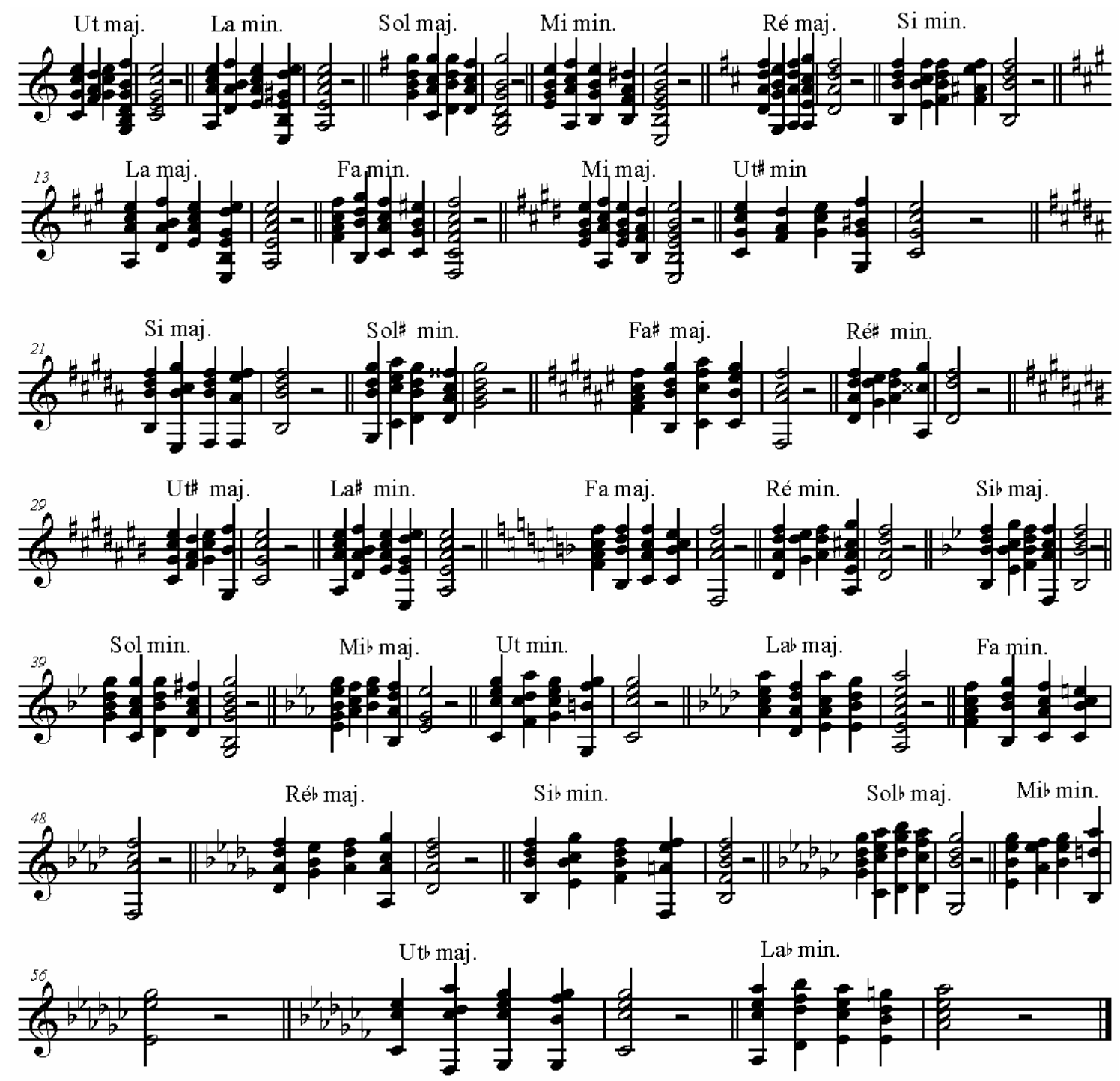

Tous les accords peuvent s'employer en

All the chords can be used as arpeggios 
arpèges et se réduire en batteries.

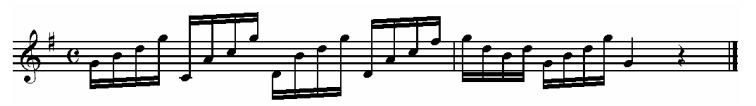

ou

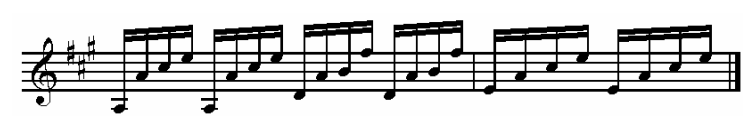

Il est à remarquer que la guitare se marie le mieux à la voix de soprano; elle est moins propre à la voix de ténor, parceque l'accompagnement est à accompagner les voix de basse. ${ }^{80,81}$

Le bissex espèce de guitare à 12 cordes fut inventé à Paris en 1770 par un chanteur nommé Van Hooke.

Cet instrument avait une étendue de trois octaves et demie. Il n'est plus usité.

\section{LE DÉCACORDE}

Le décacorde n'est autre chose qu'une guitare à 10 cordes, dont cinq seulement ont un doigté, les cinq autres réunies à deux des premières, forment ensemble sept notes de basse a vide, (tandis que la guitare ordinaire n'a que trois cordes de basse à vide: Mi, La, Ré.) and be reduced to percussive effects.

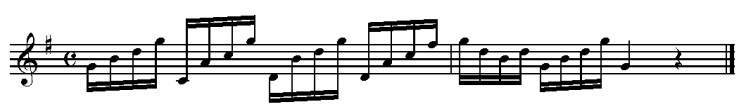

or

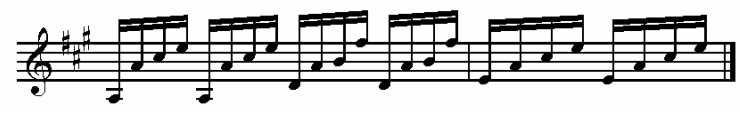

It is to be noticed that the guitar blends

best with the soprano voice; it is less

suitable to the tenor voice, because the

accompaniment is intended to accompany

bass voices.

The bissex guitar with 12 strings was invented in Paris in 1770 by a singer named Van Hooke.

This instrument had a range of three and one-half octaves. It is no longer used.

\section{THE DECACORD}

The decacord is no more than a guitar with 10 strings, only five of which are fingered; the other five join the others in pairs, together forming seven open bass notes, (while the ordinary guitar has only three open strings: E, A, D). 
Pour pouvoir se servir de ces notes à vide, To be able to use these open notes in dans différens tons, on a adapté au cheviller different tones, three small devices were trois petites hachines au moyen desquelles affixed to the bridge; these were used to on dièze a volent l'Ut le Fa et le Sol. raise C, F, and G up one semi-tone, when desired.

Les accompagnements sont beaucoup plus Accompaniments are much easier on this faciles sur cet instrument que sur la guitare, instrument than on the guitar, and the flat et les tons bémolises qui offrent tant de keys that offer so many difficulties on the difficultés sur cette dernière, n'en guitar do not present any at all on the présentent pas du tout sur le décacorde, en bémolisant à l'avance les cordes basses à strings in advance. vide.

Les dix cordes de cet instrument sont:

The ten strings of this instrument are:
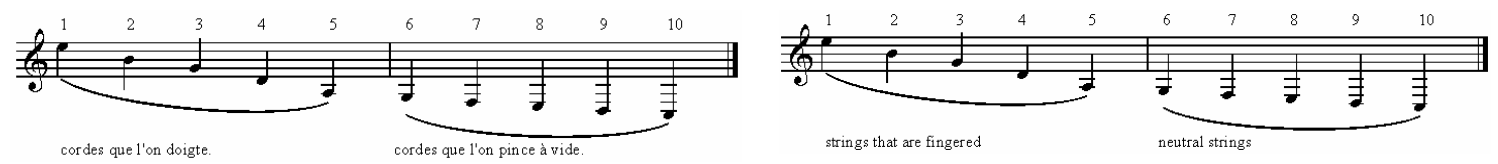

les accords se jouent de la manière

the chords are played in the following suivante. way:
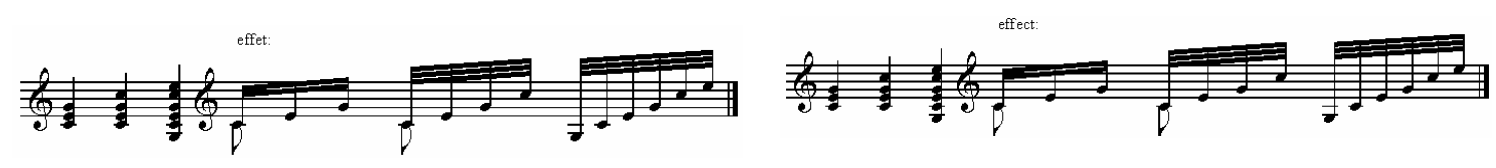

Comme nous l'avons déjà dit, on accorde

les cordes basses dans différens tons suivant que l'exige le morceau de musique; par exemple; lorsqu' on joue en $\mathrm{Mi}$, on
As we have already said, one tunes the low strings in difference tones according to what the piece of music requires; for example; when one plays in E one lowers 
baisse la 10e corde d'un demi-ton ce qui

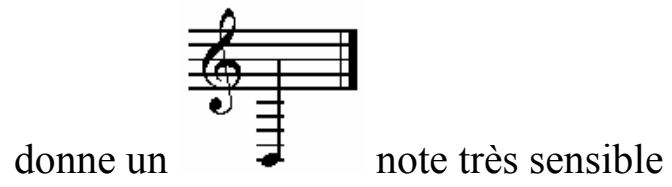

dans ce ton; d'un autre côté on hausse le R

au Ré\#;

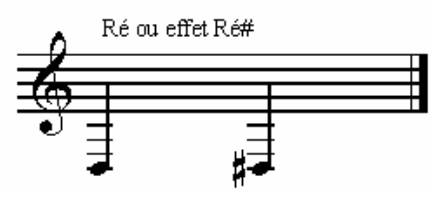

enfin,

ou opère dans l'accord les divers

changemens que voici: ainsi que nous

venons de le dire, on baisse l'Ut au Si et

l'on dièze le Ré; on dièze en outre le Fa et

le Sol; mais il faut avoir soin d'écrire tous

ces signes et tête de la partition.

Pour jouer en Ré, on dièse le Fa et l'Ut; et ainsi de suite pour les autres tons.

S'il se présente un passage de basse dans

les notes doigtées de médium de la guitare,

il est plus avantageux et plus facile de

l'exécuter à l'octave inférieure, sur les

cordes à vide; par exemple:

Guitare ordinaire.

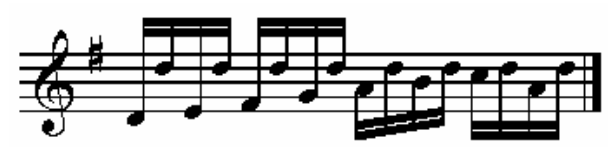

the tenth string a semitone, which

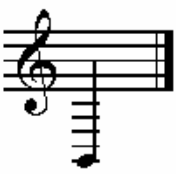

produces

a very distinct note in to $\mathrm{D} \sharp$; finally

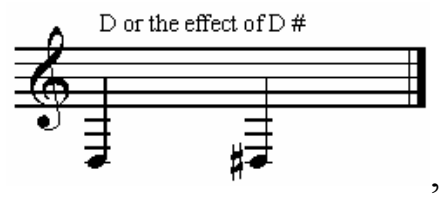

in this key the following various changes

occur, as we have just noted: one drops C

to $\mathrm{B}$ and one sharpens $\mathrm{D}$, one moreover

sharpens $\mathrm{F}$ and $\mathrm{G}$; but one must be sure to

include all of these designations in the

score's heading.

To play in $\mathrm{D}$, one sharpens $\mathrm{F}$ and $\mathrm{C}$; and so on for the other keys.

If a low passage is written in fingered

middle notes for the guitar, it is easier and more advantageous to play the bass part an octave lower, on the open strings; for example:

Standard guitar

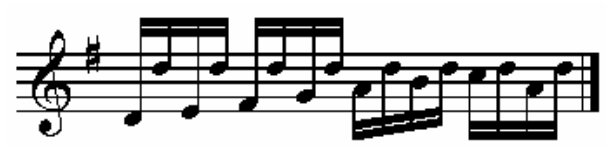


ce passage sur le Décacorde:

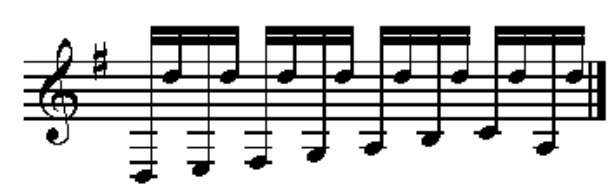

En général toutes les notes graves dont le doigté serait embarrassant pour la main, doivent s'exécuter une octave plus bas.

Pour tout le reste cet instrument se traite absolument comme la guitare, et on peut y jouer presque toute la musique composée pour la guitare.

Il y a sur le manche du décacorde, cinq positions qui sont, à partir de la première corde: 1 st Fa, ou Fa\#; $2^{\text {nd }}$ Sol ou Sol \#; 3rd La, ou La\#; 4th Si ou Si \#; 5th Ut, ou Ut\#; et ainsi de suite progressivement pour les autres cordes.

Les accords parfaits des tons les plus favorables pour cet instrument sont:

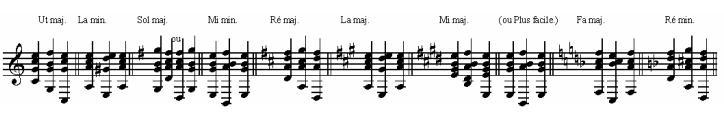

Le timbre du décacorde est presqu'aussi beau et aussi brillant que celui de la harpe. this passage on the decacord:

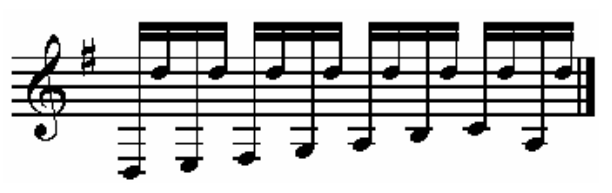

In general all the low notes whose fingering is difficult or cumbersome for the hand, must be played one octave lower. For all others, this instrument is treated exactly like the guitar, and one can use it to play almost all the music that is written for the guitar.

On the neck of the decacord there are five positions which are, starting from the first string: first $\mathrm{F}$, or $\mathrm{F} \sharp$; second $\mathrm{G}$, or $\mathrm{G} \sharp$, third A, or A\#; fourth B or B $\sharp$; fifth C, or $\mathrm{C} \#$; and so on for the other strings.

The triads of the most suitable keys for this instrument are:

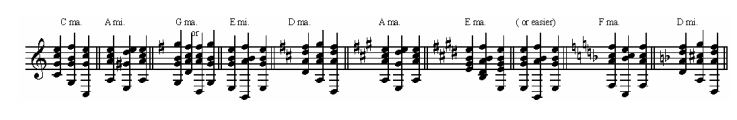

The timbre of the decacord is also almost as beautiful and brilliant as that of the harp. 
Mr. Carulli qui en est l'inventeur, a aussi écrit une Méthode pour cet instrument. ${ }^{82}$

\section{LE LUTH}

Cet instrument porte des cordes en boyau dont quelques unes de la basse sont entourées de fil; sa forme est à peu près celle d'une tortue; on le tient de la main gauche dont les doigts agissent en même tems; le petit doigt de la main droite sert encore à soutenir l'instrument, et les quatre autres pincent les cordes.

Sur le manche étaient disposés des degrés en corde à boyau pour chaque demi-ton; au lieu de notes, s'indiquaient par une lettre de l'alphabet; toutefois au dessus de la portée, qui était de six lignes, on écrivait aussi ordinairement les notes en regard des lettres, à cause de la division de la mesure; Par exemple:

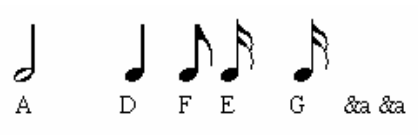

On ne mettait aucune clef en tête de la portée; on se contenait seulement
Mr. Carulli, who invented the decacord, also wrote a Method for this instrument. THE LUTE

This instrument uses gut strings; some of the bass strings are wrapped in wire; its shape is similar to that of a tortoise; one holds it with the left hand whose fingers play at the same time; the pinky finger of the right hand is used to support the instrument, and the four others grip the strings.

Gut-stringed frets for each semitone were arranged on the neck; instead of notes they were indicated by a letter of the alphabet. However, at the top of the staff, which was composed of six lines, one also usually wrote the names of the notes in addition to the letters, because of the measure's division, for example:

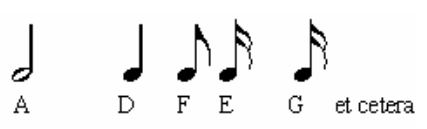

There was no key signature at the beginning of the staff; one merely 
d'indiquer la mesure du morceau.

Les trois notes les plus graves de la basse se désignaient par des chiffres; les quatre suivantes par la lettre A, avec de petites barres; et les six lignes tracées s'appelaient A, bien qu'il n'y en eut effectivement que trois qui fussent des cordes à vide;

$A$ B $C$ D $E$ E $F$ G a

Exemple:

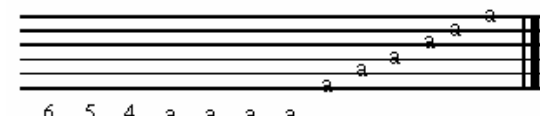

Le luth avait vingt-quatre cordes divisées

de treize chœurs, savoir: onze de deux

cordes et les deux plus élevés d'une seule.

Les huit cordes les plus graves servaient

pour la basse, les autres en suivant un

mouvement ascensionnel étaient destinées

au chant (à la mélodie).

Le luth était un instrument très riche en

tons, car on pouvait obtenir et donner le

même ton au moins sur trois cordes

différentes, suivant que l'exigeait la facilité

du doigté. ${ }^{83}$

Le premier degré de chaque corde indicated the time signature.

The three lowest bass notes were

indicated by numerals; the next four notes

by the letter A, with small bars; and the

six ledger lines were called A, although

there were indeed only three of them

which were open strings; for example:

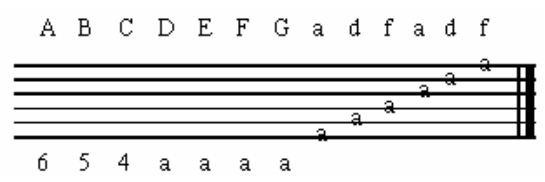

It is known that the lute had twenty-four

strings divided into thirteen choruses:

eleven of two strings, and two higher

choruses of only one string.

The eight lowest strings were used for the bass; the others, while following an

upward movement were intended for

singing (with the melody).

The lute was an instrument that was very

rich in tone, because one could play the

same pitch on at least three different

strings, if one had a good fingering

technique.

The first degree, or fret, of each string was 
s'appelait $\mathrm{B}$, le second $\mathrm{C}$; le troisième $\mathrm{D}$; le called $\mathrm{B}$, the second $\mathrm{C}$; the third $\mathrm{D}$; the quatrième $\mathrm{F}$; et cetera, mais, comme nous fourth $\mathrm{F}$; and so on, but, as we have l'avons déjà observé, ces degrés ne already observed, these degrees formed formaient que des demi-tons; par exemple, only semitones; for example, the su sur la quatrième partie du luth se following letters were on the fourth part of trouvaient les lettres A, B, C, D, E, F, G, H, the lute: A, B, C, D, E, F, G, H, I, J, K, L, I, J, K, L, M, N, cela donnerait pour notre $\mathrm{M}, \mathrm{N}$; this would give our ear, in the tenor oreille, dans le diapazon de ténor, la range, the following chromatic scale: gamme chromatique suivante:
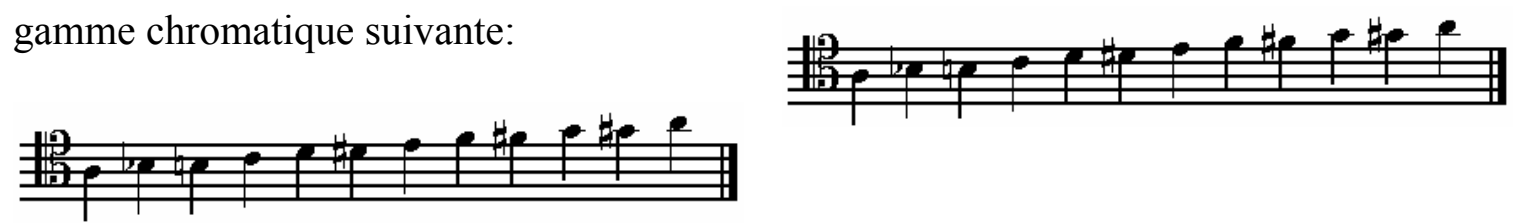

On pouvait jouer sur le luth dans tous les

One could play on the lute in all keys, but tons, mais il fallait avoir soin d'accorder à l'avance, dans l'octave la plus basse, les \# ou + nécessaires au morceau, parceque les cordes de cette octave restaient dans leur accord et ne pouvaient changer au moyen du doigté. ${ }^{84}$

Cette obligation où l'on se trouvait This need to tune the instrument each time d'accorder chaque fois l'instrument, ou du (or at least the low strings) contributed not moins les cordes graves, ne contribua pas a little in making it entirely forgotten. peu à le faire oublier entièrement. L'accord général était ordinairement en Ré The general tuning was usually in D 
mineur, et l'accord partiel de chaque corde minor, and the partial chord of each string était: La, Sib de la contre octave; Ut, Ré, $\quad$ was: A, B b of the low octave; C, D, E, F, Mi, Fa, Sol, La de la grande octave; Ré, Fa, G, of the great octave; D, F, A, of the La de la $2^{\mathrm{e}}$ petite octave. small octave; and D, F, A, of the second small octave.

Le Luth était jadis un instrument très aimé; Formerly, the lute was a very popular on l'employait pour accompagner en instrument; it was used to accompany the accords et en arpèges, le récitatif et la recitative and the love song in chords and romance. arpeggios.

Quelques grands artistes y exécutaient Some great artists also performed aussi des ouvertures et autres morceaux du même genre. overtures and other similar pieces on the lute.

Le luth disparut peu à peu à mesure que la guitare prit sa place. ${ }^{85,86}$

The lute disappeared little by little as the guitar took its place.

\section{LE THÉORBE}

\section{THE THEORBO}

Le théorbe est une grande espèce de luth The theorbo is a large type of lute which qu'on appelait aussi luth basse; il avait à la is also called the bass lute; it had at its basse huit cordes très fortes, deux fois plus lowest eight very strong strings - twice as longues que celles du luth. Les cordes long as those of the lute. The low strings graves étaient disposées par chœurs de were laid out by choruses of two strings deux cordes chaque, et le second chœur each, and the second chorus was usually s'accordait ordinairement à l'octave du tuned to the octave of the first. The high premier. Les cordes hautes étaient aussi strings were also tuned by choruses of two 
accordées par chœurs de deux cordes

chaque; excepté toutefois la chanterelle ou

quinte; mais les cordes hautes de chaque

chœur étaient à l'unisson. ${ }^{87}$

Le corps de l'instrument ressemblait

exactement au luth; seulement le col était

beaucoup plus long à cause des cordes

graves.

On se servait du théorbe dans la musique

d'église et d'opéra, pour accompagner le

chant en accords; ou comme on s'exprimait

dans le tems, pour jouer la basse générale.

Le théorbe a disparu comme le luth.

Allessandro Piccinini a écrit une Méthode

pour cet instrument (Bologne, 1680). ${ }^{88}$

LA MANDORE

La mandore était aussi une espèce de luth,

mais plus petite; la forme en était à peu

près la même; mais l'accord en était tout

différent.

La mandore n'avait que huit chœurs de

cordes, (pour un chœurs deux cordes,) dont strings each; except however the

chanterelle or fifth; but the high strings of

each chorus were in unison.

The body of the instrument resembled the lute exactly, except the neck was much longer because of the low strings.

The theorbo was used in the music of church and opera, to accompany singing

in harmonies; or as one expressed oneself at the time, to play the general bass.

The theorbo disappeared in the same manner as the lute.

Allessandro Piccinini wrote a method for this instrument (Bologne, 1680).

THE MANDORE

The mandore was also a type of lute, but smaller; the shape was about the same; but its tuning was very different.

The mandore had only eight choruses of strings, (two strings for each chorus) with 
chaque chœur s'accordait à l'unisson ou à

l'octave; le ton le plus élevé n'avait qu'une

seule corde.

Les trois cordes les plus hautes

s'accordaient en Mi mineur; quant aux

quatre plus graves, il fallait, comme pour le

luth, les accorder chaque fois dans le ton du

morceau.

Les cordes à vide s'appelaient dans la

tablature: A; et les cordes soumises au

doigté s'appelaient: B, C, D, E, F, G, H, I,

$\mathrm{K}, \mathrm{L}, \mathrm{M}, \mathrm{N}$, et $\mathrm{O}$.

\section{LA MANDOLINE}

La mandoline ressemblait au luth quant à la forme et à la manière de la traiter; mais elle en différait par le nombre de cordes.

Il y avait deux espèces de mandolines, la

mandoline Napolitaine et la mandoline

Milanaise.

La première avait quatre chœurs de deux cordes, accordés en Sol Sol, Ré Ré, La La, $M i M i$; les $M i$ étaient en boyau; les $L a$ en each chorus tuned to the unison or the octave; the highest tone had only one string.

The three highest strings were tuned in $\mathrm{E}$ minor; as for the four lower strings, it was necessary, as for the lute, to tune them each time in the tone of the piece.

The open strings in the fingering chart were called: A; and those strings which were fingered were called: B, C, D, E, F, G, H, I, K, L, M, N, and O

\section{THE MANDOLIN}

The mandolin resembled the lute in its shape and the manner in which one treated it; but it differed from it by the number of strings.

There were two types of mandolins, the Neapolitan mandolin and the Milanese mandolin.

The first had four choruses of two strings, tuned to G G, D D, E E, the Es were made of gut; the As of steel, the Ds of twisted 
acier, les Ré en cuivre jaune tordu, et enfin

les $S o l$ en boyau recouvert d'un fil

d'argent.

La seconde avait cinq chœurs accordés en Sol Sol, Ut Ut, La La, Ré Ré, Mi Mi.

Ces deux espèces de mandolines étaient plus petites que la mandore; elles e différaient un peu par la forme et aussi, comme on vient de le voir, par l'accord des cordes.

Elles s'écrivaient toutes deux sur la clef de $S o l, 2^{\text {nd }}$ ligne; leur étendue générale était:

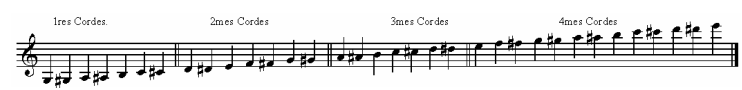
Et pareillement tous les tons bémolisés.

Avec accompagnement de guitare, la mandoline produit un très bel effet.

Nous avons des Méthodes pour cet instrument de BERTOLAZZI, FOUCHETTI, LEONE (de Naples) et autres. ${ }^{89}$

\section{LE SISTRE}

Il ne faut pas confondre cet instrument avec le sistrum (sistre) des anciens. Le sistre, brass, and finally $\mathrm{G}$ of gut covered with silver wire.

The second had five choruses tuned to $\mathrm{G}$ G, C C, A A, D D, E E.

These two types of mandolins were much smaller than the mandore; they differed somewhat in shape and also, as just seen, by the tuning of the strings.

They were both written on the G clef; their general range was:

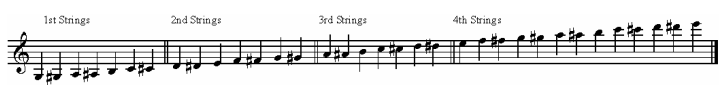

And also all of the flatted notes.

With guitar accompaniment, the mandolin produced a very pretty effect.

There are methods for this instrument by BERTOLAZZI, FOUCHETTI, LEONE (de Naples) and others.

\section{THE CITTERN}

One should not confuse this instrument with the sistrum (sistre) of old. The 
qu'on appelle aussi quelquefois guitare

Allemande, a pris naissance du vieux citre

Allemand, à quatre cordes, et a été

perfectionné en France. On l'emploie,

comme la guitare, seulement pour

accompagner le chant; set instrument

s'écrit sur la clef de Sol, $2^{\text {nd }}$ ligne; il a sept

cordes qui étaient accordées en Sol de la

grande octave; $U t, F a$, Sol de la petite

octave, et $U t, M i$, Sol de la $2^{\text {nd }}$ petite

octave; mais, afin de n'employer qu'une

seule clef, on écrivait les notes une octave

plus haut;

\section{Exemple:}

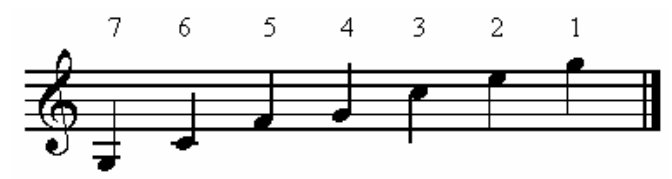

On trouve souvent aujourd'hui des sistres accordés comme suit:

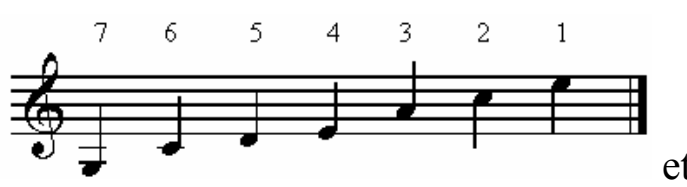

ainsi d'une tierce mineure plus bas. cittern or the German guitar as it is also sometimes called, was born of the old German citre, with four strings, and was perfected in France. It is used, like the guitar, only to accompany the voice; this instrument is written on the G clef; it has seven strings which were tuned to G of the great octave; C, F, G of the small octave, and C, E, G of the second small octave; but, in order to use only one key, one wrote the notes an octave higher; for example:

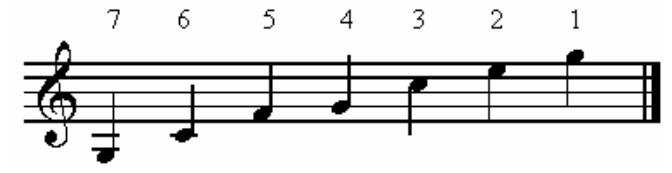

Today, one often finds citterns tuned as follows:

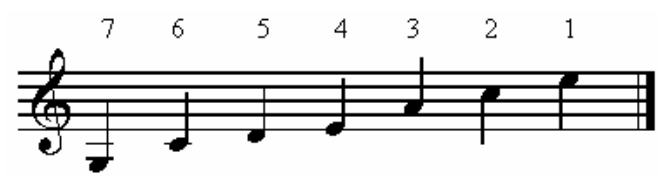

and thus a minor third lower.

The range in notes of the first chord is: 


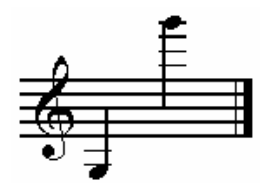

Chromat: et celle du second

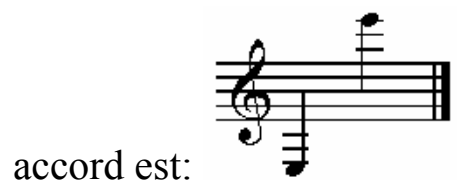

Chromat:

En général cet instrument n'est plus que

fort peu usité.

\section{LA HARPE}

La harpe est un instrument qui porte 41

cordes; son étendue générale

est:

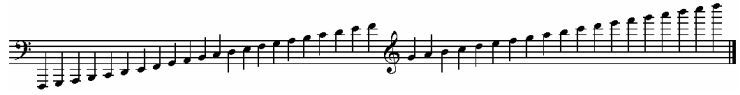

mais l'étendue à employer dans l'orchestre

n'est que de:

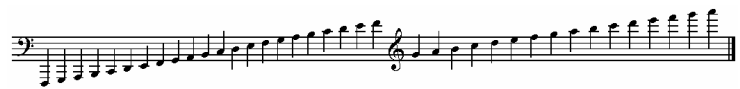

L'effet des tons est exactement celui

indiqué par les notes; de même que le

piano forte, la harpe s'écrit sur deux

portées; la portée inférieure est portée sur

la clef de $F a$ 4th ligne, et la portée

supérieure sur a clef de $\operatorname{Sol} 2^{\text {nd }}$ ligne.

La manière de composer pour la harpe est

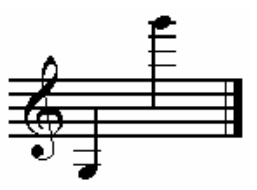

chromatically: and that of

the second chord is:

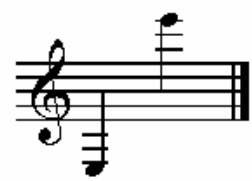

chromatically.

In general this instrument is used very

little.

\section{THE HARP}

The harp is an instrument which has 41

strings; its general range is:

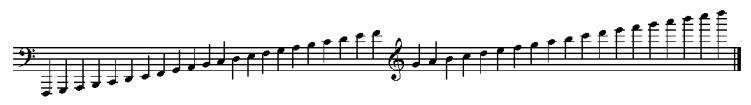

but the range to be used in the orchestra is

only:

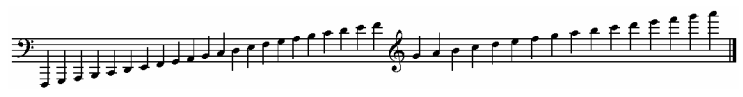

The effect of the tone is exactly that

indicated by the notes; just as with the

pianoforte, the harp is written on two

staves; the lower staff is related to the

bass clef, and the higher staff on the treble

clef.

The manner of composing for the harp is 
tout-à-fait identique à la manière de

composer pour le piano; et, très souvent

des compositions pour l'un de ces deux

instrumens se jouent [p]our l'autre.

Toutefois dans l'orchestre, les

compositions pour la harpe consistent

principalement et accompagnemens

d'accordes pour Récitatifs, Solos, ou

Romances, et plus rarement en modulations

d'un passage à un autre.

La harpe ordinaire comprend dans son

étendue tous les tons et demi-tons, mais ces

derniers ne s'obtiennent pas naturellement,

car pour les produire on est obligé d'avoir

recours à un mécanisme nommé pédale, et

lorsqu'on fait mouvoir une pédale, on dièze

à la fois tous les tons correspondans de

chaque octave; par exemple tous les $\mathrm{Sol}$ se

changent en $\mathrm{Sol} \#$; tous les $\mathrm{Fa}$ en $\mathrm{Fa} \#$ et

ainsi de suite; on voit par là qu'il ne faut

jamais exiger dans la portée inférieure une

note naturelle, et dans la portée supérieure

la même note avec un dièze; completely identical to the manner of composing for the piano; and, very often the compositions for one from these two instruments is played for the other.

However in the orchestra, the compositions for the harp consist mainly and accompaniments of tunings for recitatives, solos, or romances, and more rarely in modulation of one passage to another.

The ordinary harp includes in its range all the tones and semitones, but the latter are not obtained naturally, because to produce them one must have a mechanism called a pedal at one's disposal; when one presses the pedal, one sharpens all the corresponding tones of each octave at the same time; for example all the Gs change into $\mathrm{G} \# \mathrm{~s}$; all $\mathrm{Fs}$ in $\mathrm{F} \# \mathrm{~s}$ and so on; thus one must never require a natural note in the lower staff, and in the higher staff the same note with a sharp: 
Par Exemple:

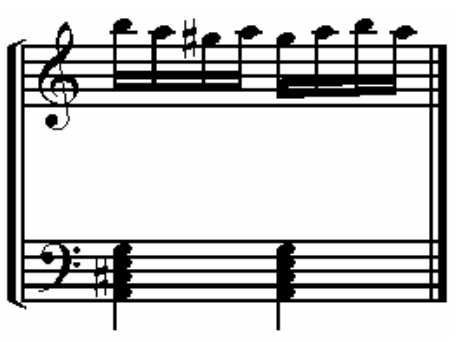

ou bien:

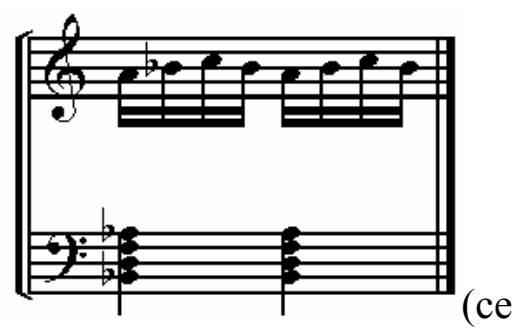

qui peut très bien se faire pour le piano.)

Il ne est de même pour tous les autres

demi-tons.

On peut très bien écrire pour une et pour

deux mains des accords de 2, 3 ou même

de 4 tons, pourvu, toutefois, que les tons

limitrophes ne dépassent pas l'étendue

d'une octave. Ces accords se houent

ordinairement en accords brisés, qu'on peut

désigner des deux manières suivantes:

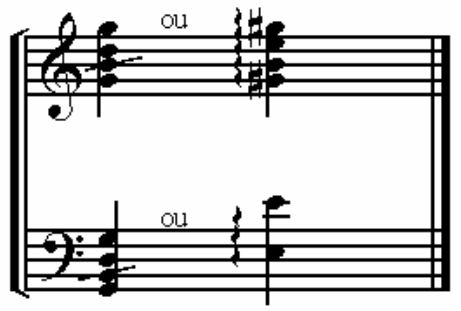

On peut aussi exécuter sur la harpe des
For example:
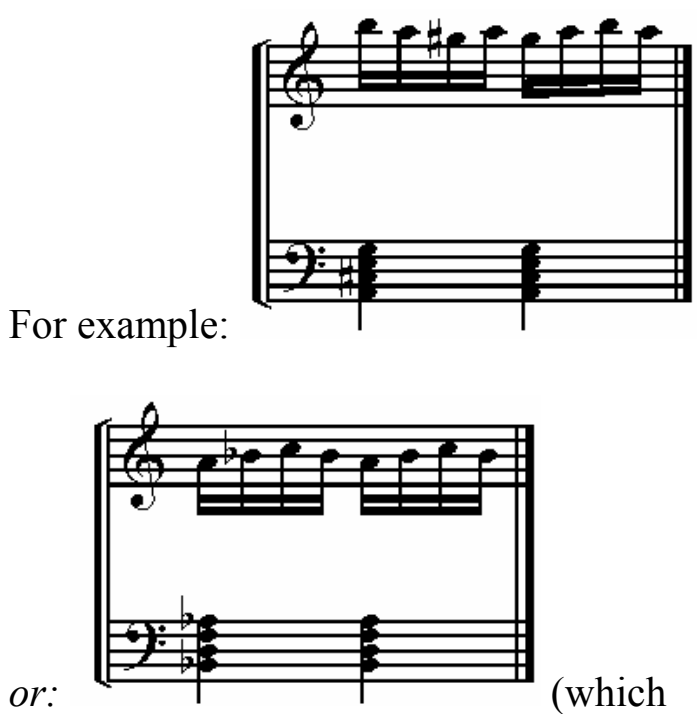

can be done very well for the piano.)

It is not the same for all the other

semitones.

One can write the two, three, and even

four-tone chords for one or two hands

very well, provided, however, that the

bordering tones do not exceed the range

by an octave. These chords are usually

played in broken chords, which one can

indicate in the two following ways:

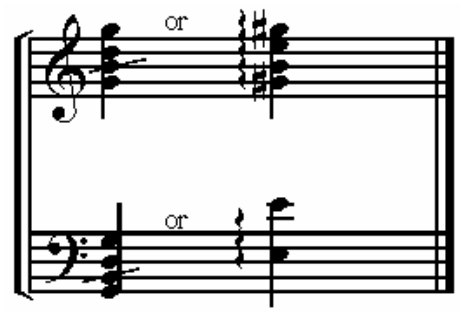

On the harp, one can also play passages in 
passages en octaves, en tierces, ou en sixtes dans toute l'étendue de l'instrument.

Les arpèges y sont très communs comme

aussi toute autre espèce

d'accompagnement.

Il ne faut pas écrire de notes tenues pour la

harpe, surtout si elles se prolongent trop

long-tems, car son jeu n'est qu'un pizzicato

continuel; cependant, pour les cadences

finales et autres cas semblables, on peut

employer des accords, parceque ces

accords se prolongent en se brisant, et

qu'en outre les cordes de la harpe

résonnent encore un certain tems après

avoir été mises en vibration.

Il arrive naturellement que par fois les deux

mains jouent tout-à-fait au grave ou tout-à-

fait à l'aigu, comme cela a lieu pour le

piano.

Les tons avec beaucoup de \# ou de b sont

plus difficiles que les tons simples, et en

général il faut éviter, dans le cours d'un

morceau, d'employer trop souvent les \# ou octaves, thirds, or in sixths over the entire expanse of the instrument.

The arpeggios are very commonly used with the harp, as are all other types of accompaniment.

One should not write sustained notes for the harp, especially if they are sustained too long, because its effect is that of a continual pizzicato; however, for final cadences and other similar cases, one can use chords, because these chords are sustained while breaking; and moreover the harp's string still resound for some time after being put in vibration.

Naturally, both hands sometimes play completely in the low or high register, which also occurs on the piano.

The keys which contain many $\# \mathrm{~s}$ or bs are more difficult than simple keys, and in general it is necessary to avoid using \# or + too often throughout a piece because, as 
les +; car, ainsi que nous l'avons observé, we have observed, one can obtain them

on ne peut les obtenir qu'au moyen des

pédales, ce qui rend le jeu beaucoup plus

difficile.

On peut exécuter des trilles sur la harpe, mais fort peu d'artistes les peuvent donner avec perfection.

Les harpes à simple mouvement ou à un seul accrochement qui sont généralement adoptées, portent 41 cordes formant cinq octaves et une sixte. Leur ton naturel est en Mi b.

L'étendue générale de la harpe en $M i b$, est:

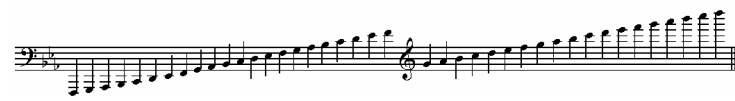

Cette harpe a sept pédales au moyen desquelles on peut jouer dans les différens tons.

Ces pédales sont: Ainsi pour jouer dans un autre ton que $M i b$ on s'y prendra de la manière suivante:

Pour jouer en Sib majeur ou Sol mineur. Accrochez la pédale La only by means of the pedals, which makes them much more difficult to play.

One can play trills on the harp, but very few artists can play them perfectly.

The simple movement harp, which is more generally used, has 41 strings forming five octaves and a sixth. Its natural key is $\mathrm{E} b$.

The general range of the harp in $\mathrm{E} b$ is:

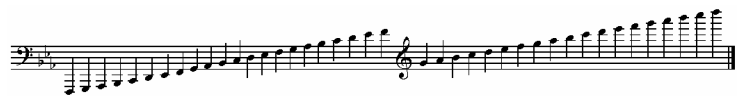

This harp has seven pedals with which one can play in different keys.

These pedals are:

In order to play in a key other than $\mathrm{E} b$ one will set about it in the following way:

To play in $\mathrm{B} b$ major or $\mathrm{G}$ minor. 


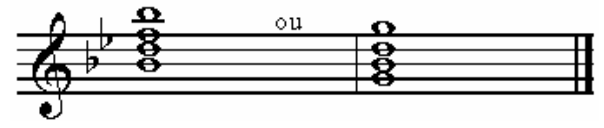

Pour jouer en $F a$ majeur ou en Ré

mineur.

Accrochez les pédales La et Mi

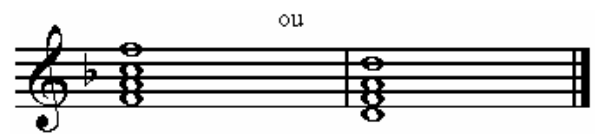

Pour jouer en $U t$ majeur ou en $L a$

mineur.

Accrochez les pédales La, Mi et Si

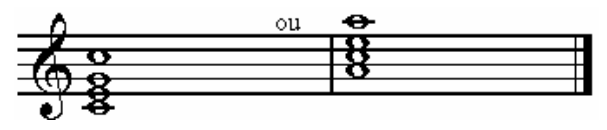

Pour jouer en Sol majeur ou en $\mathrm{Mi}$

mineur.

Accrochez les pédales La, Mi, Si et Fa \#

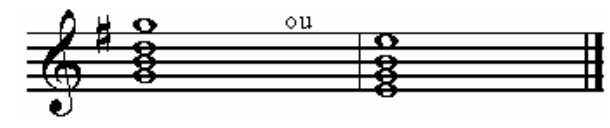

Pour jouer en Ré majeur ou en $\mathrm{Si}$

mineur.

Accrochez les pédales La, Mi, Si, Fa\# et

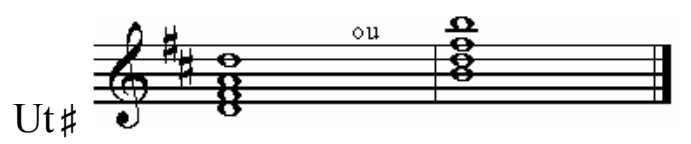

Pour jouer en $L a$ majeur ou en $F a \#$

mineur.

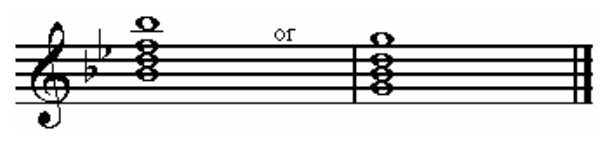

To play in F major or D minor.

Depress the A and E pedals

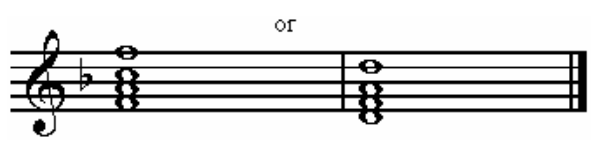

To play in $\mathrm{C}$ major or A minor.

Depress the A, E and B pedals

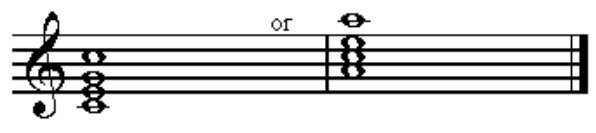

To play in $\mathrm{G}$ major or $\mathrm{E}$ minor.

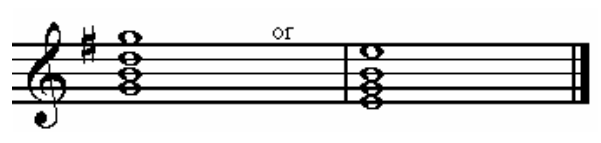

To play in D major or B minor.

Depress the A, E, B, F\# and $\mathrm{C} \#$ pedals

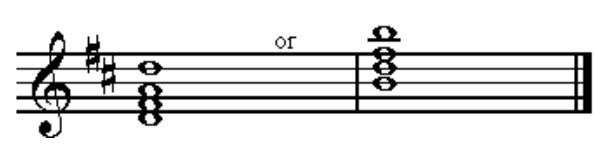

To play in the A major or $\mathrm{F} \#$

minor. 
Accrochez les pédales La, Mi, Si, Fa $\sharp$, Ut $\#$

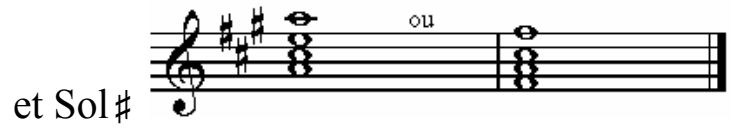

Pour jouer en Mi majeur ou en Ut\#
Depress the A, E, B, F\#, C\# and G\#

pedals

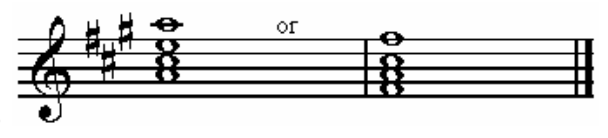

To play into $\mathrm{E}$ major or $\mathrm{C} \sharp$ minor. mineur.

Accrochez les pédales $\mathrm{La}, \mathrm{Mi}, \mathrm{Si}, \mathrm{Fa} \#$,

Ut\#, Sol\#, et Ré\#

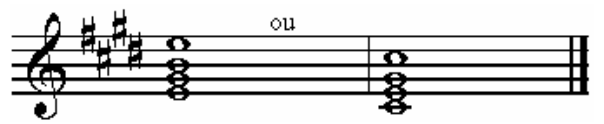

Les trois tons mineurs: Si mineur, Fa \#

mineur, et Ut $\#$ mineur, ne peuvent être

caractérisés dans leurs septièmes sensibles

que par leurs synonimes [sic].

Pour indiquer le nom d'un synonyme, il faut le placer entre deux parenthèses; par

exemple:

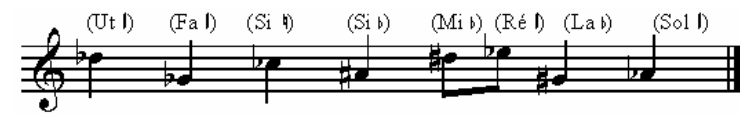

Ces six synonimes surtout doivent être essentiellement observés, parcequ'ils sont une source de facilités pour le jeu des pédales, et que par les moyens les plus simples, ils ouvrent à l'essor de la harpe un
Depress the A, E, B, F\#, C\#, G\#, and D\# pedals

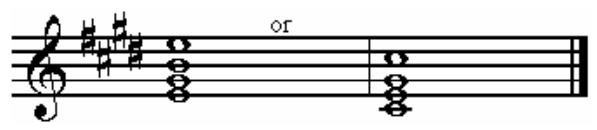

Three minor keys: $\mathrm{B}$ minor, $\mathrm{F} \#$ minor and $\mathrm{C} \#$ minor, can be characterized in their sevenths perceptible only by their enharmonics.

To indicate the name of an enharmonic, it should be placed between two brackets, for example:

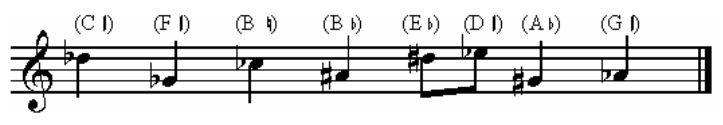

These six enharmonics in particular must be closely observed because they enable one to master the use the pedals, and because by the simplest means, they open a much wider field with the rise of the 
champ beaucoup plus étendu.

Une autre manière de se servir des pédales, Another manner of using the pedals

consiste à les abaisser sans les fixer, pour

produire momentanément les demi-tons

accidentels qui se trouvent dans la

musique.

Il y a donc, comme on voit, deux façons

d'employer les pédales, l'une fixe et l'autre

accidentelle.

Les abréviations dont on se sert le plus souvent dans la musique de harpe, sont: Acc: Accrochez. fix: Fixe. déc.

Décrochez. Ot: Otez

d'av: d'avance. déc: Décrochez

d'av: d'avance.

La harpe à simple mouvement peut suffire à presque tous les morceaux de musique, et passer par toutes les modulations, avec plus ou moins de difficulté; et si quelques gammes seulement lui sont interdites, c'est dans des tous presque inusités; encore peutelle les remplacer à la faveur des synonimes. harp. consists of lowering them but not fastening them, to temporarily produce the semitones which are, coincidentally, in the music.

There is thus, as one can see, two ways of using the pedals: one fixed, and the other on not being fixed.

The abbreviations which one generally uses for harp music are:

Acc: Accrochez. fix: Fixe. déc.

Décrochez. Ot: Otez

d'av: d'avance. déc: Décrochez

d'av: d'avance.

The simple movement harp can be used for almost all the types of music, and can go through all the modulations, with more or less difficulty; and those few scales that are prohibited to it are the most uncommon ones; and in any case, the harp can replace these scales in favor of enharmonics. 
Nous avons des Méthodes pour la harpe de: There are methods for the harp by:

JACQUES MEYER, WERNICH,

BOCHSA, BACKOFEN, HEYSE, NADERMANN, MADUDE, POLET, WENZEL, DESARGUS et autres. ${ }^{90}$

\section{LA HARPE à double mouvement.}

La harpe à double mouvement, ou à double accrochement, inventée et perfectionnée

par M. M. Erard, a conservé la légèreté et la simplicité premières des systèmes de harpes à simple mouvement, elle n'a que sept pédales comme les anciennes, mais chacune de ces pédales produit un effet double, parcequ'on lui a donné deux crans d'arrêt, ou de repos. On l'accroche au premier cran pour le premier demi-ton, et au $2^{\text {nd }}$ cran pour le $2^{\text {nd }}$ demi-ton. Ainsi ces sept pédales suffisent pour rendre chaque corde représentative de trois sons. ${ }^{91}$

Cette harpe est accordée en Ut $b$ majeur (au lieu de l'être en Mib); et chaque corde représentant trois sons, comme on vient de le dire, peut donner le bémol, le bécarre et
JACQUES MEYER, WERNICH, BOCHSA, BACKOFEN, HEYSE, NADERMANN, MADUDE, POLET, WENZEL, DESARGUS and others. THE DOUBLE-ACTION HARP

The double action (or double accrochement) harp, invented and perfected by Mr. Erard, preserved the original lightness and simplicity of the simple-movement harps' systems. It has only seven pedals like the old harps, but each one of these pedals produces a double effect, because each was given two stop notches. One depresses the pedal to the first notch for the first semitone and to the second notch for the second semitone.

Thus these seven pedals are enough to make each string produce three sounds.

This harp is tuned in $\mathrm{C} b$ major (instead of in $\mathrm{E} b$ ); and since each string produces three sounds, as previously mentioned, the flat, the natural and the sharp of the same 
le dièze $[s i c]$ d'une même note de notre

diapazon; par exemple:

$\mathrm{Ut} b, \mathrm{Ut} \curvearrowleft, \quad \mathrm{Ut} \#$,

Ré b, Ré h, Ré\#,

Mib, Miø, Mi

$\mathrm{Fa} b, \mathrm{Fa}$, $\mathrm{Fa}$,

Sol b, Sol $\downarrow$, Sol $\sharp$,

Lab, La

Sib, Siø, Si \#

La harpe à double mouvement se prête à

toutes les modulations possibles, et donne à

l'artiste les moyens de rendre avec facilité

les tons les plus difficiles et même

inexécutables sur l'ancienne harpe; par

exemple:

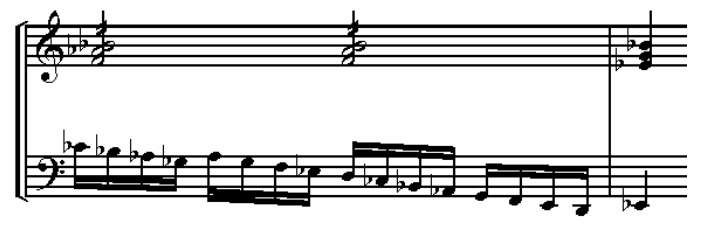

$\&$ ou

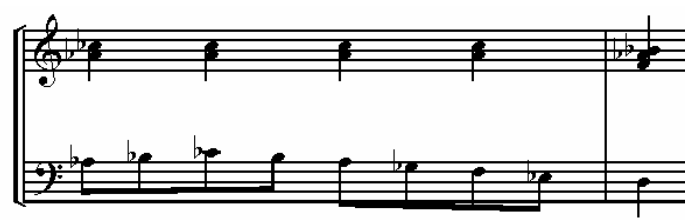

Ces passages absolument impraticables sur note can be produced; for example:

$\mathrm{Cb}, \quad \mathrm{C}$ h, $\mathrm{C} \sharp$,

$\mathrm{D} b, \quad \mathrm{D} \sharp, \quad \mathrm{D} \#$,

$\mathrm{E} b, \quad \mathrm{E}$,, $\mathrm{E} \sharp$,

$\mathrm{F} b, \quad \mathrm{~F}$,$\quad \mathrm{F} \#$,

$\mathrm{G} b, \quad \mathrm{G}$,$\quad \mathrm{G} \#$,

$\mathrm{A} b, \quad \mathrm{~A} \sharp, \quad \mathrm{A} \#$,

$\mathrm{B} b, \quad \mathrm{~B}$,$\quad \mathrm{B} \#$

The double action harp lends itself to all

possible modulations, and gives the artist

the ability to easily play the keys that

were most difficult and even

impracticable to execute on the old harp;

for example:

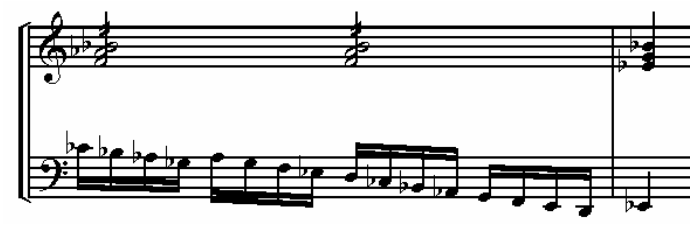

\& or

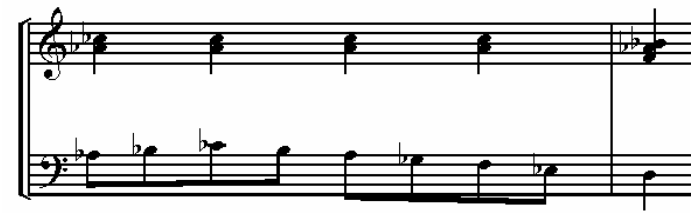

These absolutely impracticable passages 
la harpe en Mi $b$, deviennent très simples sur la harpe à double mouvement en Ut $b$.

Cet instrument qui dans le principe

rencontra quelque opposition, est

aujourd'hui généralement apprécié des

artistes, et les grands harpistes, du moins en

France, ne se servent plus que des harpes à

double mouvement en Utb majeur de

M.M. Erard.

On a sur cet instrument une notice de M.M. There is a short article on this instrument

Erard et de Prony. ${ }^{92}$

\section{LE GUSSEL ou GUSLI}

Est un instrument à cordes usité en Russie; sa forme est celle du clavecin, ou plutôt il ressemble à une harpe couchée horizontalement; les cordes qui sont d'acier se pincent avec les doigts, et les demi-tons s'obtiennent, comme sur les anciennes harpes, au moyen d'un mouvement de pression.

L'étendue de cet instrument est de deux octaves et demie.

LA HARPE Ditale. on the harp in $\mathrm{E} b$ become very simple on the double-action harp in $\mathrm{C} b$.

This instrument, which in the beginning met some opposition, is generally appreciated by artists today, and the great harpists, at least in France, no longer use any harp other than Mr. Erard's double action harp in $\mathrm{C} b$ major.
GUSSEL or GUSLI

It is a stringed instrument used in Russia; its shape is the same as that of the harpsichord, or rather it resembles a harp laid down horizontally; the steel strings are gripped with the fingers, and the semitones are obtained, as on the old harps, by means of applying pressure.

The range of this instrument is two and a half octaves.

THE Ditale HARP 
Inventée par Mr. Pfeiffer, est ainsi

nommée, parceque le mécanisme au moyen

duquel on élève chaque note d'un demi-

ton, se meut par la pression du doigt au lieu

de celle du pied, Le ton de cette harpe est

d'une intensité surprenante, eu égard à sa

petit dimension; quatre octaves en forment

l'étendue; elle perd beaucoup moins

facilement son accord que les harpes

ordinaires, en raison du peu de longueur

des cordes. C'est un instrument

d'accompagnement plutôt que d'exécution,

qui est très usité pour les commençants.

\section{LA HARPE d'Eole.}

La harpe d'Eole est le seul instrument de

musique qui produise des sons sans le

secours d'un joueur ou d'un mécanisme

adapté à l'instrument. Les cordes se la

harpe Eolienne sont mises en vibration et

résonnent au moyen d'un simple courant

d'air.

Son nom lui vient de ce qu'Eole était chez

les anciens le Dieu des vents.
Invented by Mr. Pfeiffer, it is thus named

because the mechanism which raises each

note a semitone is driven by finger

pressure rather than foot pressure. The

tone of this harp is of a surprising

intensity in proportion to its small

dimension. Its range is formed by four

octaves; it loses its tuning much less

easily than the ordinary harp, because of

the short length of the strings. It is an

instrument of accompaniment rather than

of execution that is very often used for

introductions.

AEOLIAN HARP.

The Aeolian harp is the only musical

instrument that produces sounds without a

player's help, or a mechanism attached to

the instrument. The strings of the Aeolian

harp are put in vibration and resound by

means of a simple current of air.

Its name comes from Eole, the ancient

God of the winds. 
Cet instrument consiste en une espèce de caisse, longue d'a peu pres $[\mathrm{sic}]$ une aune et demie et d'environ huit pouces de hauteur et de largeur, confectionnée avec de petites planchettes d'un quart de pouce en sapin; la partie supérieure ou couvercle se fait aussi d'un bois léger et vibrant; la face postérieure reste ouverte; à chaque extrémité du couvercle est adapté un chevalet en bois dur, haut d'un demi-pouce [sic]; en dehors d'un de ces chevalets sont plantées de petites pointes métalliques où les cordes sont fixées à demeure; elles vont aboutir, à l'autre extrémité de l'instrument et derrière l'autre chevalet, à des chevilles ajustées à travers la table, dans un petit écrou en bois dur qui sert à les maintenir dans la position qu'on leur imprime pour l'accord, et qui empêche en même tems que la tension des cordes ne fasse rompre le couvercle qui, comme nous l'avons déjà dit, est des plus fragiles. On prend ordinairement huit à douze cordes à boyau
This instrument consists of a kind of case, approximately an ell and a half in length and eight inches in height and width, constructed of small fir tree planks a quarter of an inch thick; the higher part (or lid) is also made of light and vibrating wood; the posterior face remains open; a bridge half an inch high and constructed of hard wood is attached to each end of the lid; apart from one of these bridges, small metal points are installed, to which the strings are permanently attached; they will lead, at the other end of the instrument and behind the other bridge, to legs fitted in the table with a small wooden nut which is used to maintain the strings in the position of the chord stamped on them, and which, at the same time, prevents the strings's tension from breaking the lid, which, as we already said, is one of the more fragile. One usually takes eight to twelve gut strings of equal force and leaves them very lax after 
de force égale, que l'on tend tout-à-fait lâches, non pas pourtant assez pour qu'elles branlent, mais de manière à donner encore un ton appréciable et déterminé; puis on les accorde toutes à l'unisson: voilà la seule préparation de cet instrument.

Quand on a tout disposé comme nous venons de l'indiquer, il suffit de placer la harpe devant une ouverture d'où le vent puisse glisser sur les cordes, par exemple devant une croisée d'appartement; si le vent ne souffle pas assez fort, on établit un courant d'air, en ouvrant par derrière une second fenêtre ou bien une porte, et alors l'instrument fait entendre des sons vraiment magiques et qui semblent venir d'un monde extérieur, en passant tour à tour $[$ sic $]$ par un crescendo merveilleusement nuancé du piano au forté ou du forté au pianissimo.

Ce jeu de la nature donne assez à réfléchir sur les facultés des corps sonnans [sic], et sur la manière sur prenante dont le son tightening them-not however enough so that they shake, but so as to still give an appreciable and predetermined tone; then one tunes them all in unison. This is the only preparation of this instrument.

When everything is arranged as we have just indicated, one merely places the harp in front of an opening from which the wind can glide over the strings, for example in front of an apartment; if the wind is not blowing strongly enough, one establishes a draft by opening a second window or door behind the harp, and then the instrument makes produces quite magical sounds that seem to come from an outer world: passing one to another in a marvelously nuanced crescendo from piano to forte or from forte to pianissimo.

This effect of nature causes one to reflect on the powers of harmonics, and on the surprising way in which the sound dies 
vient s'éteindre mourir dans chaque intervalle isolé. ${ }^{93}$ out in each isolated interval. 
CHAPITRE III. Instrumens à clavier.

LE TYMPANON. (ou manicorde.)

Cet instrument qui vraisemblablement a

donné naissance au clavecin avait une

étendue de trois octaves, et chaque ton était

rendu par deux ou trois cordes à la fois; on

le touchait avec de petites baguettes en

bois, portant à leur extrémité des boutons

allongés qui frappaient les cordes de

chaque ton; l'autre extrémité de ces

baguettes était garnie de feutre au moyen

de quoi l'on pouvait aussi jouer piano de

l'instrument.

Dans les forté le tympanon rendait un son

bruyant; on trouve encore cet instrument

dans quelques campagnes où il sert à

fortifier l'orchestre de danse villageois.

LE CLAVECIN

Cet instrument si aimé, si recherché

autrefois, et sur lequel nos plus grands

maîtres acquirent ce degré de force qui fait

notre admiration, est complètement
CHAPTER III. Keyboard Instruments

THE DULCIMER. (or manicorde.)

This instrument, which in all likelihood

gave rise to the harpsichord, had a range of

three octaves, and each key was given by

two or three strings at the same time; one

touched it with small wooden rods, which

were fitted with elongated buttons; these

struck the strings in each key. The other

end of these rods was covered with felt,

which was used to play piano.

In forte the dulcimer made a noisy sound; one still finds this instrument in some rural areas where it is used to strengthen the village dance ensemble.

\section{THE HARPSICHORD}

This instrument, on which our great masters obtained their reputations and our admiration, was very well-liked and sought-after in the past, but has been 
abandonné de nos jours. Le clavecin avait pour renforcer chaque ton deux cordes par touche qui étaient accordées à l'unisson. Les premiers clavecins ne s'étendaient qui depuis l'Ut de la grande octave, jusqu'à l'Ut de la 4th petite octave; dans la suite on y ajouta encore de nouveaux tons au grave et à l'aigu, de sorte qu'on pouvait descendre jusqu'au contre $\mathrm{Fa}$ et même au contre Ut et monter jusqu'au Sol et même au La de la 4th petite octave.

Nous avons des Méthodes pour le clavecin de DORI, LAMBERT, E. BACH, KAUER, TURK, DUSSEK, MULLER, PLEYEL et autres. $^{94,95}$

LE FORTE PIANO, (ou piano forte, ou piano à queue \&)

Le piano est l'instrument à touches le plus répandu de nos jours, et il est devenu pour ainsi dire un meuble indispensable dans toute famille aisée; aussi chacun connaît-il trop généralement cet instrument, pour que nous avons besoin d'en donner une longue completely abandoned since then. To reinforce each key, the harpsichord had two strings which were tuned to unison. The first harpsichords' range was only from C of the great octave, to $\mathrm{C}$ of the fourth small octave one still added new keys to the low and high registers, so that one could go down to contra F and even $\mathrm{C}$, and go up to $\mathrm{G}$ and even A of the fourth small octave.

There are Methods for the harpsichord by DORI, LAMBERT, E. BACH, KAUER, TURK, DUSSEK, MULLER, PLEYEL and others.

THE FORTE PIANO, (or piano forte, or grand piano \&)

The piano is the most widespread keyboard instrument nowadays, and it became, so to speak, an essential piece of furniture in any well-to-do family.

Therefore, since virtually everyone knows this instrument, so there is no need to give 
description.

Il dérive du clavecin, et Geoffroi

SILBERMANN, (qui l'inventa en 1726,)

lui donna le nom de forté-piano,

parcequ'on pouvait y observer à volonté les

piano ou les forté, ce qui n'a pas lieu sur le

clavecin.

Tout le monde connaît les différens genres

et formes des pianos qu'on fabrique

aujourd'hui avec une rare perfection.

L'étendue ordinaire commence au Fa de la contre octave et va jusqu'au Fa de la 5th petite octave:

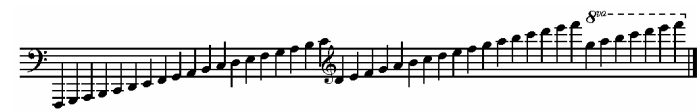

Sur le piano à queue, et aussi sur quelques autres pianos, l'étendue commence à l'Ut de la contre octave, et va jusqu'au Fa et même au Sol de la 5th petite octave; on trouve même des pianos qui descendent jusqu'au Sib au dessous du contre Ut, et montent jusqu'au La de la 5me petite octave, et même à l'Ut de la 6th petite a long description of it.

It derives from the harpsichord, and Geoffroi SILBERMANN, (who invented it in 1726) gave it the name forte-piano, because it was observed that it could play piano or forte, which is not possible on the harpsichord.

Everyone is familiar with the different kinds and shapes of the pianos which are manufactured today with a rare perfection.

The normal range starts with $\mathrm{F}$ of the contra-octave and goes to $\mathrm{F}$ of the fifth small octave:

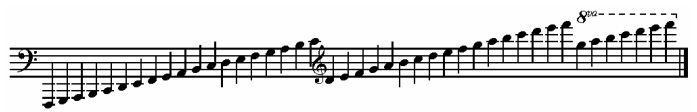

On the grand piano, and also on some other pianos, the range starts with $\mathrm{C}$ of the contra-octave, and goes to $\mathrm{F}$ or even $\mathrm{G}$ of the fifth small octave. There are even pianos which go down to $\mathrm{B} b$ below the contra-octave $\mathrm{C}$, and up to $\mathrm{A}$ of the fifth small octave, and even to $\mathrm{C}$ of the 6th small octave. 
octave. $^{96}$

Toutefois l'étendue suivante saffit $[\mathrm{sic}] \quad$ However, the following range is sufficient pour pouvoir jouer toute espèce de composition:

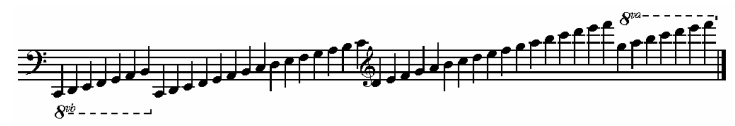

for any type of composition:

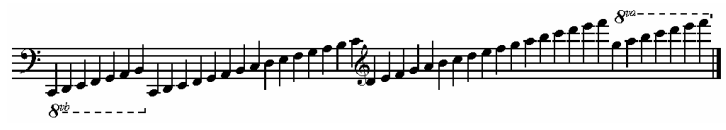

Au reste, comme je l'ai déjà observé, le

Moreover, as I already observed, the piano est d'un usage trop général, pour piano is too general in use, so to go into qu'il soit nécessaire d'entrer ici dans des detail here is unnecessary; and because détails qui m'entraîneraient trop loin; et this instrument is completely essential to comme d'ailleurs cet instrument est tout-àfait indispensable aux compositeurs, je composers, I assume that they will have access to one of the excellent methods suppose qu'ils auront entre les mains une available today, in which they will be able des excellentes méthodes qui entraient to find any and all desired information. spécialement, et dans lesquelles ils

pourront puiser tous les renseignemens [sic] désirables.

Nous avons des Méthodes pour le piano de: There are methods for the piano by:
ADAM, CLEMENTI, CRAMER, BACH,
ADAM, CLEMENTI, CRAMER, BACH, BERTINI, CHAULIEU, CZERNY, BERTINI, CHAULIEU, CZERNY, PLEYEL et DUSSEK, VIGUERIE, PLEYEL and DUSSEK, VIGUERIE, GARAUDÉ, HUMMEL, MÜLLER, GARAUDÉ, HUMMEL, MÜLLER, STEIBELT, KALKBRENNER, la STEIBELT, KALKBRENNER, method 
Méthode du Conservatoire de Paris, TÜRK, WERNER, et encore beaucoup d'autres. ${ }^{97}$

\section{L'ORGUE}

L'orgue est l'instrument le plus grand et le plus complet, le plus intéressant et le plus parfait. On peut dire qu'il réunit en lui tous les autres instrumens, car ses tons ne sont en effet que des imitations et transpositions de chacun des instrumens en un seul.

L'orgue exige un artiste consommé qui connaisse à fond le mécanisme de

l'instrument, et l'art d'en mêler les différens registres; qui possède en outre toute la facilité désirable dans le doigté et l'action des pieds, enfin qui soit encore doue d'une imagination vive et féconde.

Chacun sait que l'orgue se compose de beaucoup de registres, (le nombre en est indéterminé et dépend de la grandeur de l'instrument) et de beaucoup plus de of the Academy of Paris, TÜRK, WERNER, and still many more others.

\section{THE ORGAN}

The organ is the largest, most complete, interesting and perfect instrument. One can say that it is possesses all good qualities of the other orchestral instruments, because its keys are, indeed, only imitations and transpositions of each of the instruments into a single whole. The organ requires a consummate artist who is thoroughly familiar with the workings of the instrument, and the art of mixing the different registers; and who, moreover, has the desirable facility in fingering and pedal work. Finally, the organ demands an artist endowed with a keen and fertile imagination.

Everyone knows that the organ is composed of many registers, (the number is unspecified and depends on the size of the instrument) and of even more pipes 
tuyaux encore. On appelle registre un jeu quelconque dont les intonations chromatiques sont produites par les touches du clavier, soit au moyen des mains, soit au moyen des pieds.

On mesure la grandeur des registres d'après le plus grand tuyau, accordé au ton d'Ut; si par exemple le tuyau qui donne cet Ut le plus grave a quatre pieds, le registre se dit de quatre pieds; s'il a seize pieds, le registre se dit de seize pieds et ainsi de suite.

Le registre duquel on part pour mesurer la grandeur des autres, soit en augmentant, soit en diminuant, se nomme Le Principal; il a huit pieds de hauteur.

Parmi les registres de 32 pieds on rencontre:

Le bombarde, le bourdon, le basson, le trombonne $[\mathrm{sic}]$ et autres.

Parmi les registres de 16 pieds on rencontre: la cornemuse, le bombarde, le bourdon, le trombonne, le salcional, la still. A register is any method by which chromatic intonations are produced by the keyboard's keys-either by using the hands, or by using the feet.

One measures the size of the registers according to the largest pipe, tuned to the key of C; if for example the pipe which produces this lowest $\mathrm{C}$ is four feet long, the register is called "four feet"; if it is sixteen feet long, the register is called "sixteen feet", and so on.

The register which one uses to measure the size of the others, either by increasing decreasing, is called the Principal; it is eight feet high.

Among the 32-foot registers one finds:

The bombarde, the bourdon, the bassoon, the trombone and others.

Among the 16-foot registers one finds: the bagpipe, the bombarde, the bourdon, the trombone, the salcional, the subbass, the 
subbasse, la contrebasse, le flautone, la viola di gamba, le principal et autres. Parmi les registres de 8 pieds on rencontre: la basse de viole, la cornemuse, le bombarde, le bourdon, la clarinette, le cornet, le cromorne ou cor courbé, le basson, la flûte douce, le hautbois, le salcional, le chalumeau, le trombonne, le principal, la sourdine; (le plus doux de tous les registres,) la trompette, la viola d'amour, la voix humaine et autres. Parmi les registres de 4 pieds on rencontre: La flûte villageoise, le clairon, (espèce de trompette,) le cornet, le cromorne, le prestant, la musette, le chalumeau, la voix humaine, le zinck, (ce registre fait le dessus des trombonnes,) la flûte de forêt et autres.

Parmi les registres de deux pieds on rencontre:

La flûte villageoise, la flûte vulgaire, la flûte traversière, la corne de chamois, la flûte des champs, la trompette et autres. double bass, the flautone, the viola da gamba, the principal and others.

Among the 8-foot registers one finds: the bass viol, the bagpipe, the bombarde, the bourdon, the clarinet, the cornet, the crumhorn or curved horn, the bassoon, the soft flute, the oboe, the salcional, the chalumeau, the trombone, the principal, the mute (the softest of all the registers) the trumpet, the viola d'amore, the human voice and others.

Among the four-foot registers one finds:

The village flute, the clairon (a type of trumpet), the cornet, the crumhorn, the octave, the haversack, the chalumeau, the human voice, the zinck (this register forms the top of the trombones) the forest flute and others. Among the two-foot registers one finds:

The village flute, the common flute, the transverse flute, the chamois horn, the field flute, the trumpet and others. 
Parmi les registres d'un pied on rencontre:

Le flageolet, la flûte villageoise, la

cymballe, la corne de chamois, la sifflet, la flûte de forêt et autres.

Outre ces registres, il y en a encore qu'on appelle registres de mixture, (comme par exemple: décima, nazard, cornet, \&) c'està-dire des registres qui donnent à la fois la tierce et la quinte de chaque touche du clavier; ces tierces et ces quintes qu'on pourrait supposer insupportables, (et qui le seraient en effet, si on les employait sans le grand jeu,) donnent à celui-ci une force et une suavité qu'il n'aurait point sans elles.

Qu'on se représente par exemple une mixture triple: en touchant Ut, on entend: $\mathrm{Ut}, \mathrm{Mi}$, Sol; en touchant Mi avec Ut, on entend: $\mathrm{Mi} \mathrm{Sol} \#, \mathrm{Si}$; enfin en ajoutant encore Sol, on entend: Sol, Si, Ré; et ainsi la réunion de tous les sons produits est $\mathrm{Ut}$, Ré, Mi, Sol, Sol\#, Si. Quel accord: et cependant tous ces tons se fondent l'un
Among the one-foot registers one finds:

The flageolet, the village flute, the cymbals, the chamois horn, the whistle, the forest flute and others.

In addition to these registers there are others which are called mixed registers, for example: decima, nazard, horn, and the like; in other words registers which produce the third and the fifth of each key at the same time; these thirds and fifths that one could imagine to be unbearable (and indeed it would be, if one used them without taking advantage of the various registers the organ produces), produces a force and a sweetness all their own. For example, a triad can be represented: by touching $\mathrm{C}$, one hears: $\mathrm{C}, \mathrm{E}, \mathrm{G}$; while touching $\mathrm{E}$ and $\mathrm{C}$ at the same time, one hears: $E, G \#, B$; finally by adding $G$ as well, one hears: G, B, D; and thus the ensemble of all the produced sounds produced is: $\mathrm{C}, \mathrm{D}, \mathrm{E}, \mathrm{G}, \mathrm{G} \#, \mathrm{~B}$. What harmony: and, moreover, all these keys 
dans l'autre, sans aucun résultat

désagréable, si, comme nous venons de le

dire, on emploie le grand jeu, c'est-à-dire,

tous les registres, ou du moins une grande

partie de ces registres.

Il y a encore un autre registre qu'on appelle

le tremblant: c'est une espèce de machine

ou plaque mobile, qu'on introduit dans le

principal canal du ventilateur; en tirant ce

registre, la plaque se dégage, s'agite au

moyen du vent et imprime à tout le jeu de

l'orgue un tremblement très sensible. Il en

existe de deux sortes: le tremblement doux

et le tremblement fort. ${ }^{98}$

Tous ces registres sont disposés à droite et

à gauche de chaque côté du clavier; ils

peuvent se tirer et se rentrer à volonté;

quand on veut par exemple que tel registre

sonne, on le tire à soi; quand on veut qu'il

ne sonne plus, on le pousse en sens inverse,

ce qui empêche le vent de pénétrer dans ses tuyaux. blend into one another without any

unpleasant result, if, as we have just said,

the full organ (i.e., all the registers, or at least most of these registers) is used.

There is still another register called tremblant: it is a kind of machine or mobile plate, which one inserts into the principal channel of the ventilator; by playing this register, the plate is released as it is agitated by the wind and together with the organ stops, it produces a very significant vibrato. Two types exist: the narrow vibrato and the wide vibrato.

All of these registers are arranged to the right and left sides of the keyboard; they can be pulled out and pushed in as desired; when one wants a particular register to sound, one pulls it towards oneself; when one wishes to end the playing of that register, one pushes it in the opposite direction, which prevents the wind from entering in the organ's pipes. 
L'orgue a ordinairement un, deux et même trois ou quatre claviers, plus des pédales consistant en touches de bois qu'on fait mouvoir avec les pieds, d'où elles ont tiré leur nom de pédales. ${ }^{99}$

Ces pédales font l'office de contrebasse et s'écrivent sur la clef de Fa 4me ligne; quelquefois on les emploie à faire des batteries, tandis que le clavier exécute des notes tenues; mais en général, elle servent principalement de basse d'harmonie, et c'est pour cela qu'il est bien d'écrire la musique d'orgue sur trois portées, savoir: deux pour le clavier, et une pour les pédales. Si les pédales ne font pas la basse fondamentale, on écrit parfois leur partie sur la même portée que la basse du clavier.

Le principal registre est ordinairement de seize pieds, (c'est-à-dire que le plus grand tuyau à 16 pieds;) ce n'est que dans les plus grands orgues qu'on trouve des registres de
The organ usually has one, two or even three or four keyboards, and pedals consisting of wooden keys which one depresses with the feet (the French word for feet being pieds, these keys were names pédales, or pedals in English). These pedals act as double bass and are written on the F clef line; sometimes one uses them to make percussive effects, while the keyboard plays sustained notes; but in general, it serve mainly as bass for the harmony, and it is for that reason it is preferable to write the organ music on three staves, namely: two for the keyboard, and one for the pedals. If the pedals are not playing the fundamental bass, one sometimes writes their part on the same staff as that of the keyboard's bass.

The principal register is usually sixteen feet long, (in other words the largest pipe has 16 feet); only the largest organs have 32-foot registers. 
32 pieds.

L'étendue du clavier de l'orgue est la The range of the organ's keyboard is as suivante:

follows:

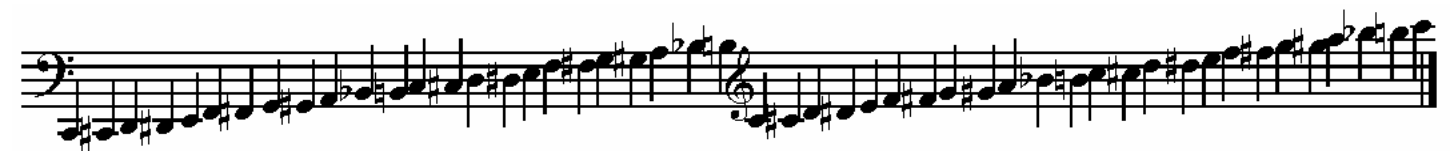

Les notes suivantes sont rares:

The following notes are rare:
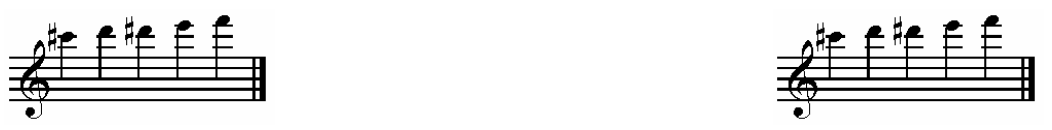

Dans beaucoup d'anciens orgues, les notes: In many old organs, the notes:
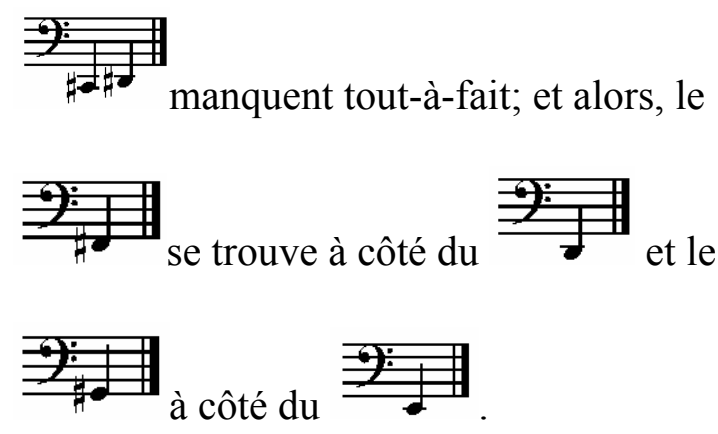

Les notes de la clef de Fa servent, tant pour

les tons graves du clavier que pour les

pédales.

L'orgue se composant, comme nous

l'avons déjà dit, d'une infinité de tuyaux,

son essence est de produire

particulièrement des notes et des accords

tenus; en général le style de sa musique
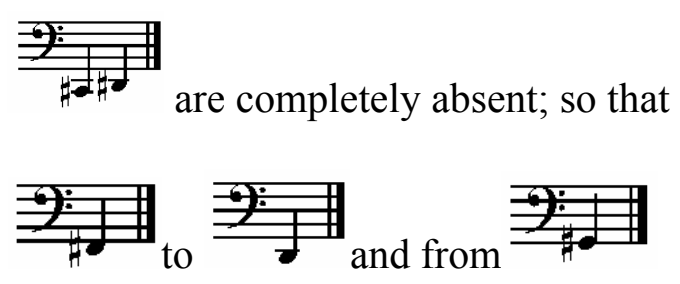

to

The notes of the bass clef are useful, both for the low notes of the keyboard and for the pedals.

Because the organ may be composed, as we already said, of any number of pipes, its essential function is particularly to produce sustained notes and chords; in general the style of its music must always 
doit toujours être grave, austère et

majestueux.

Les passages ou accords coupés sont toutà-fait contre sa nature; cependant quelques registres font exception à cette règle; par exemple la flûte, le hautbois, le chalumeau, le flageolet et encore quelques autres auxquels on peut donner des solos, concertos, variations, $\&$ dans ce cas, ces registres sont accompagnés de la viola di gamba, du basson et autres registres semblables.

Les tutti se font avec le plein jeu, c'est-àdire avec tous les registres.

Pour les passages rapides on d'une certaine étendue on se sert du Principal sur le Positif; (on nomme positif une petite espèce d'orgue de $3,4,5,6,7$ et tout au plus 8 registres, et qui n'a qu'un clavier sans pédale.)

On donne encore ce nom au petit orgue qui tient au grand. be serious, austere and majestic.

The passages or arpeggios are completely contrary to its nature; however some registers make exception to this rule, such as the flute, the oboe, the chalumeau, the flageolet and a few others, which can play solos, concertos, variations, and the like. In this case, these registers are accompanied by the viola da gamba, the bassoon and other similar registers.

The tutti are done with the full organ; in other words, with all the registers.

For the fast passages in a certain range, one uses the Principal on the Positif; ('positif' refers to a small variety of organ consisting of $3,4,5,6,7$, or at most 8 registers, which has only one keyboard and no pedals).

One still gives this name to the small organ (which a descendant of the large organ). 
Du reste, tout cela dépend du talent du

l'organiste qui peut obtenir les plus beaux

résultats du bon choix des registres, tandis

qu'il n'arrive qu'à des effets bizarres et

comiques s'il emploie un mélange de

caractères opposés.

Les artistes doivent s'accoutumer à un

doigté continu et serré; il faut que les

accords soient bien liés ainsi l'organiste, en

modulant d'un ton dans un autre, doit être

sur ses gardes et préparer ses doigts pour le

autres touches, afin de ne pas causer

d'interruption choquante, chose qu'on

néglige souvent sur le piano, et qui n’y

produit que peu d'inconvénient dans un

mouvement lent, tandis qu'il en arrive tout

autrement à l'égard de l'orgue. Il faut aussi

toucher régulièrement et avec une égale

force toutes les touches du clavier, car,

lorsqu'on les frappe trop faiblement, le ton

de l'instrument perd de sa force.

Le jeu à quatre parties avec quelques
Moreover, all of the above is dependent upon the talent of the organist, who can obtain the most beautiful results with good choice of registers; while only odd and comic sounds are produced if one uses a mixture of registers of opposite natures.

The artists must become accustomed to a continuous and tight fingering; the chords must be well-linked and the organist, while modulating from one key to another, must be on guard and prepare his fingers to reach the other keys, in order to avoid causing a shocking interruption, something which one often neglects on the piano, but which causes however only a slight disadvantage in a slow tempo (on the piano), however on the organ, this is not the case. One must also apply steady and even pressure to all the keys, because when they are struck too lightly, the instrument's key loses its force. Using a few registers of moderate timbre 
registres d'un timbre modéré, fait plus

d'effet que le plein jeu à deux on à trois parties.

L'alternative entre les claviers (par exemple le plus faible du positif et le plus

fort de tout l'orgue) produit un effet surprenant et merveilleux.

Le style lié et fugué à trois et quatre parties dans un tempo moderato est le meilleur, mais aussi le plus difficile, et celui-là seul peut donner droit au titre d'organiste distingué.

Le clavier de l'orgue se touchant exactement comme celui du piano, le doigté est le même pour les deux instrumens, et l'on peut même jouer sur l'orgue avec le plus grand effet, des adagios et autres morceaux semblables composés pour le piano, si toutefois l'étendue du clavier le permet, (car, comme on peut le voir, l'étendue du piano est bien plus considérable).

Au théâtre on emploie quelquefois l'orgue for four-part play is more effective than the full organ with two or three parts.

Alternating between the keyboards (for example, the weakest of the positif, and the strongest of the full organ) produces a surprising and marvelous sound.

The legato and fugue style in three and four parts, in a moderate tempo, is the best for this instrument, but is also the most difficult and entitles the master of such styles the rank of a distinguished organist. As the organ's keyboard is touched exactly like that of the piano, the fingering is the same for both instruments, and on the organ, one can even play-and obtain the greatest effect-adagios and other similar pieces composed for the piano; however, only if the range of the organ's keyboard allows it (because, as one can see; the range of the piano is much more extensive).

In the theatre, one sometimes uses the 
pour des morceaux d'un caractère religieux et solemnel [sic]; dans ce cas un chant simple et gracieux avec de belles modulations devra toujours être choisi de préférence.

Le compositeur qui veut écrire expressément pour l'orgue, doit étudier la nature de cet instrument dans toutes ses parties, et connaître à fond tous les registres usités de nos jours.

Ce détail nous entraînerait trop loin, et exigerait une trop grande quantité de planches explicatives; c'est dans des ouvrages spécieux sur la construction de l'orgue et sur la manière de le toucher, qu'on trouvera les renseignemens indispensables pour bien composer. Nous avons des ouvrages sur la construction de l'orgue, de: Schlimbach; Zang; Wolfram; Becker, Guill Schneider, Adolphe Müller et autres. ${ }^{100}$

Nous avons des Méthodes pour toucher l'orgue, de: Clementi; Knecht; Martini; organ for pieces of a religious and solemn nature; in this case it would be best to select a simple and gracious song with beautiful modulations.

The composer who wants to write expressly for the organ must study the nature of this instrument in all its parts, and thoroughly know all the registers used today.

To go into such detail here would be too involved and would require too many explanatory illustrations; it is in specious works on the construction of the organ and the manner of playing it, that one will find the information essential for composing well.

There are works on the construction of the organ by: Schlimbach; Zang; Wolfram; Becker, Guill; Schneider, Adolphe Müller and others.

There are methods to play the organ by: Clementi, Knecht, Martini, Rink, 
Rink; Schneider; Turk; Lasceux;

Sonnenkalb; L'abbé Vogler; Werner, F.

Schneider, Adolphe Miné et autres. ${ }^{101,102}$

\section{L'ORCHESTRION.}

Il y a deux instrumens différens qui portent ce nom; le premier, inventé en 1789 par

L'abbé Vogler, appartient proprement aux instrumens à vent; c'est un orgue portatif figurant un cube d'environ neuf pieds, mais dont le ton a autant de force que celui d'un orgue de seize pieds. Cet instrument fait entendre toutes les parties d'un orchestre, ce qui lui a fait donner le nom d'orchestrion. Il a quatre claviers, chacun de 65 touches et une pédale de 39 touches.
Schneider, Turk, Lasceux, Sonnenkalb, the Abbé Vogler, Werner, F. Schneider, Adolphe Miné and others.

\section{THE ORCHESTRION.}

There are two different instruments which bear this name; the first, invented in 1789 by the Abbé Vogler, belongs properly to the wind instruments; it is a portable organ shaped like a cube and approximately nine feet in length, but whose tone has as much force as that of a sixteen-foot organ. This instrument plays all the parts of an orchestra, which gives it the name orchestrion. It has four keyboards, each of which has 65 keys, and a 39-key pedal.

Le second instrument de ce nom fut inventé The second instrument of this name was par Ant: Kunz à Prague, en 1796; c'est une espèce de forté-piano à peu près de la forme d'un piano à queue dont la caisse a trois pieds neuf pouces de haut, sept pieds six pouces de long, et trois pieds deux pouces de large par devant; il a deux invented by A. Kunz in Prague, in 1796; it is a type of forte-piano whose shape is approximately that of a grand piano, and whose case is three feet nine inches high, seven feet six inches in length; and three feet two inches across; it has two 
claviers, du Fa de la grande octave jusqu'au keyboards which range from F of the great La de la $4 .{ }^{\mathrm{me}}$ petite octave en 68 touches, et octave to A of the fourth small octave in une pédale de l'Ut (16 pieds;) cet 68 keys, and a $C$ pedal ( 16 feet); this instrument peut se jouer comme le forté- instrument can be played like the fortepiano et aussi comme l'orgue; il y a pour le piano and also like the organ; there are 14 clavier 14 registres de tuyaux et pour la registers of pipes for the keyboard and pédale trois, plus un tremblement fiable et three for the pedal, plus a reliable and fort. strong tremor.

\section{L'ORGUE DE BARBARIE. (Organum BARREL ORGAN (PORTATIVE portabile) ORGAN)}

Cet instrument consiste en une caisse This instrument consists of a square case carrée renfermant deux à trois registres de tuyaux, d'une étendue de trois octaves, qui résonnent au moyen d'un cylindre sur lequel la mélodie est arrangée avec de petites pointes métalliques. containing two to three registers of pipes, with a range of three octaves, which resonates by means of a cylinder upon which the melody is arranged with small metal points.

Un manche qui ressort à l'extérieur fait A handle which protrudes outside the case tourner le cylindre dont les pointes ouvrent successivement des soupapes qui turns the cylinder, whose points successively open valves which carry communiquent aux tuyaux le vent fourni wind (provided by a generator) to the par un ventilateur, habituellement on pipes. Usually one releases a certain dispose sur le cylindre une certaine quantité d'airs qu'on obtient par un cran d'arrêt quantity of air, obtained by means of a specific safety catch, onto the cylinder. 
déterminé.

Il y a encore une autre espèce d'orgue

portative plus petite, qu'on nomme

serinette et qu'on emploie pour apprendre à

chanter aux oiseaux. Elle a depuis huit

jusqu'a 12 tuyaux.

\section{L'ORGUE EXPRESSIF.}

L'orgue expressif n'est autre chose que le

physarmonica des Allemands; cet

instrument a la forme d'un piano, mais les

tons en sont produits par des anches

métalliques.

En touchant le clavier, on ouvre une

soupape qui communique le vent aux

anches avec plus ou moins de force. Le

ventilateur se dirige avec le pied.

On a des orgues expressifs de trois à cinq et

même six octaves. Les morceaux d'un

mouvement lent sont ceux qui conviennent

le mieux à cet instrument. La manière de

composer pour lui est la même que pour le

piano; seulement on doit éviter les figures

trop rapides qui n'y feraient pas bon effet.
There is still another smaller type of

portable organ called the serinette; one

uses it to learn how to "sing with the

birds". It has between eight and twelve pipes.

\section{EXPRESSIVE ORGAN}

The expressive organ is nothing more than what the Germans call a "physarmonica"; this instrument is in the shape of a piano, but the tones are produced by metal reeds.

By touching the keyboard, one opens a valve which carries the wind to the reeds with more or less force, as desired. The ventilator is moved by the foot.

There are expressive organs from three to five and even six octaves. Pieces written in a slow tempo are those which are most appropriate for this instrument. The manner that one composes for the expressive organ just as one does for the piano; only one must avoid very fast 
figures, which would not produce a good effect.

\section{L’ACCORDÉON.}

L'accordéon ordinaire est un instrument à anches renfermé dans une petite caisse qui se dilate et se ressèrre [sic] à volonté, et produit ainsi les tons au moyen du mécanisme d'un doigté à touches.

Son étendue est diatoniquement de Si de la petite octave à l'Ut de la $5 .{ }^{\text {me }}$ petite octave:

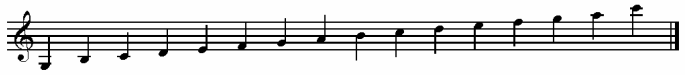

Excepté le La de la petite octave:

et le Si de la $3 .^{\text {me }}$ petite octave:

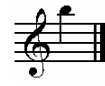

\section{THE ACCORDIAN}

The ordinary accordion is a reed instrument contained in a small case which dilates and recedes as desired, and thus produces sound by means of fingered keys.

Its range is, diatonically, from $\mathrm{B}$ of the small octave to $\mathrm{C}$ of the fifth small octave:

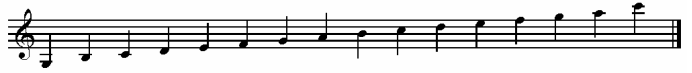

Except the A of the small octave:

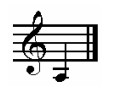

and $\mathrm{B}$ of the third small octave:

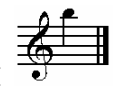

But there are also accordions which can play sharped and flatted notes in this range; one even finds some with a range of three and a half octaves (chromatically).

One can play small simple arias and even a few chords. In other applications, this instrument is of very little importance. 
importance.

On a pour l'accordéon une petite Méthode For the accordion, there is a small method

de Reisner. ${ }^{103}$

authored by Reisner.

L'AEOLODICON.

THE AEOLODICON.

L'aeolodicon est un instrument à touches

The aeolodicon is a keyed instrument with

d'une étendue de six octaves par tons et

a range of six octaves in tones and

demi-tons.

semitones.

Les tous sont produits par des anches

All are produced by metal reeds, put in

métalliques mises en vibration au moyen

vibration by air.

de l'air.

On peut y observer un crescendo ou un

One can observe a well-marked crescendo decrescendo bien marqué, selon qu'on

or a decrescendo, depending on the force

fournit le vent avec plus ou moins de force. with which one supplies one provides the instrument with wind.

Son timbre est agréable sous plusieurs

Its timbre is pleasant in several respects;

rapports; à l'aigu il a quelque ressemblance in the high register, it has some

avec la flûte et la clarinette; dans le

resemblance to the flute and the clarinet;

médium avec le cor, et enfin au grave avec in the middle register to the horn, and

le contrebasson; mais il conserve

finally in the low register it resembles the

néanmoins dans toute son étendue un

double bassoon; but nevertheless it

caractère tranchant et métallique.

preserves a sharp and metallic character

over its entire range.

Cet instrument se prête surtout à des

This instrument lends itself especially to 
morceaux d'un mouvement lent, et d'un sentiment religieux.

L'ANEMOCORDE.

L'anémocorde est un instrument à clavier d'une étendue de cinq octaves par tons et demi-tons.

Chaque touche du clavier aboutit à trois cordes.

Dans l'intérieur sont disposés deux ventilateurs et une grande quantité de tuyaux en cuivre jaune pesant ensemble plus de 500 liv.

Les touches en s'abaissant font ouvrir des soupapes qui donnent passage au vent, et les cordes commencent à résonner.

Il y a en outre au dessus de clavier, quatre registres destinés à modifier la force du vent et à produire des crescendo ou des decrescendo qui sont vraiment d'un effet surprenant.

L'instrument a une rare suavité de sons et les pianissimo ressemblent à des sons aériens qui arrivent comme de loin. pieces in slow tempo and with a religious feeling.

THE ANEMOCORDE.

The anemocorde is a keyboard instrument with a range of five octaves in tones and semitones.

Each key of the keyboard ends in three strings.

Inside, two ventilators and a great quantity of brass pipes are laid out, weighing a total of more than 500 pounds.

The keys, upon being depressed, open valves that let wind pass, and the strings begin to resonate.

Moreover, on top of the keyboard there are four registers intended to modify the force of the wind and to create a crescendo or decrescendo, which produce truly amazing effects.

The instrument has a rare sweetness of sound and the pianissimo sounds light and airy, and as though it is arriving from 
some far-off place.

Cet instrument ne convient qu'à des

morceaux d'un mouvement lent, comme adagio, andante, $\&^{\mathrm{a}}$.

Il fait aussi très bon effet en accompagnant le chant.

\section{L'HARMONICA}

Dans le principe, cet instrument consistait

en une boîte d'un carré long avec un couvercle en forme de coffre. Un pied ou support soutenait toute la machine.

L'harmonica se composait de cloches dont le nombre variait de 56 à 40, et qu'on fabriquait dans les verreries sur des moules à ce destinés. Ces cloches s'emboîtaient l'une dans l'autre, mais néanmoins sans se toucher. Une baguette ou fuseau les transperçait et les maintenait dans une position horizontale, à peu près comme des pigeons sur une brochette.

Un balancier adapté à la machine imprimait à ce fuseau un mouvement de rotation, les cloches étaient disposées de manière à se
This instrument is only appropriate for pieces in slow tempos, such as adagios, andantes, and the like.

It also makes a very good effect when accompanying song.

\section{THE GLASS HARMONICA}

As a rule, this instrument consisted of a long, square box with a lid in the shape of a trunk. A support or foot supported the entire mechanism.

The harmonica was composed of bells whose number varied from 56 to 40 , and which was manufactured in glasswork shops on molds created for this purpose. These bells were encased one inside the other; however they did not touch one another. A rod or spindle pierced them and held them in a horizontal position, like pigeons on a skewer.

A beam attached to the instrument caused the spindle to rotate; the bells were arranged so that they rubbed against the 
mouvoir contre le joueur, et celui-ci les mettait en vibration en les frôlant avec les doigts mouillés.

L'étendue de cet harmonica allait ordinairement de l'Ut de la petite octave jusqu'au Fa de la $4 .{ }^{\text {me }}$ petite octave chromatiquement; son timbre était doux et sonore et on pouvait y observer sans difficulté les nuances les plus délicates; mais comme cette manière de frôler les cloches attaquait souvent les personnes nerveuses ou sentimentales, on chercha à perfectionner le mécanisme de l'instrument et on imagina de faire sonner les cloches au moyen d'un clavier.

L'entendue de l'harmonica à clavier, va du Fa de la grande octave jusqu'au Sol de la 4. ${ }^{\text {me }}$ petite octave:

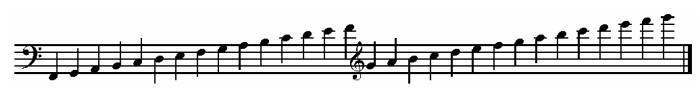

Les accords et autres figures s'y exécutent absolument comme sur le piano; toutefois, ainsi que nous l'avons dit, on doit éviter les passages trop rapides, et s'attacher de player, and the player made them vibrate by brushing them with wet fingers.

The range of this harmonica usually went from $\mathrm{C}$ of the small octave to $\mathrm{F}$ of the fourth small octave, chromatically. Its timbre was soft and sonorous and one could easily make the most delicate nuances; but because the technique of lightly brushing the bells often by nervous or sentimental people, one sought to improve the mechanism of the instrument by using a keyboard to sound the bells.

The range of the keyboard harmonica goes from $F$ of the great octave to $G$ of the fourth small octave:

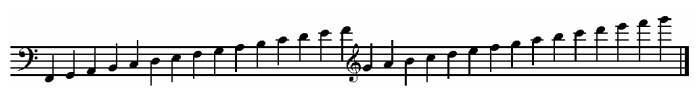

Chords and other figures are played the same way as on the piano; however, as previously stated, one must avoid fast passages, and instead use pieces in a slow 
préférence aux morceaux d'un mouvement lent comme chorals, adagio, et autres semblables qui lui conviennent infiniment mieux, à cause de son timbre tendre et gracieux. Il est à remarquer que les modifications du ton sont bien plus fines et mieux nuancées sur la $1 .{ }^{\text {re }}$ espèce que sur la 2 me $^{\text {me }}$ cela provient peut-être de la chaleur des doigts.

Nous avons une Méthode pour l'harmonica de Müller. ${ }^{104,105}$

\section{LE POIKILORGUE.}

Cet instrument n'est qu'une addition applicable à tous les pianos en général; il consiste en un jeu expressif de trois octaves, depuis le Fa de la petite octave jusqu'au Fa de la 5. ${ }^{\text {me }}$ petite octave. L'addition de ce nouvel instrument aux pianos, ne change rien à leur forme extérieure et n'altère point leur timbre.

A l'aide d'un bouton placé sur la devanture de clavier, le poikilorgue dans les dessus, et le piano dans les basses, ou bien le piano et tempo such as chorals, adagio, and other similar pieces, which are infinitely more appropriate because of its tender and gracious timbre. It is to be noted that key modifications are much finer and better nuanced on the first type of harmonica than on the second, due perhaps to the heat of the player's fingers.

There is a method for the harmonica by Müller.

\section{THE POIKILORGAN.}

This instrument is merely an applicable addition to all pianos in general; it consists of an expressive range of three octaves, from $\mathrm{F}$ of the small octave to $\mathrm{F}$ of the fifth small octave.

The addition of this new instrument does not change the pianos' shape, nor does it impair their timbre.

Using a button placed on the keyboard's shelf, the poikilorgan on top, and the piano in the basses, or the piano and the 
le poikilorgue dans les dessus et le piano dans les basses.

Cet instrument qui a obtenu un assez grand succès est de l'invention de M. M.

Cavaillé. ${ }^{106}$ poikilorgan on top and the piano in the basses.

This instrument has been a fairly successful invention by Mr. M. Cavaillé. 
CHAPITRE IV. Instrumens à vent.

\section{LA FLÛTE.}

La Flûte est un instrument très répandu et propre à toute espèce de musique. Elle avait l'étendue de Ré de la $2 .{ }^{\text {me }}$ petite octave à La de la $4 .{ }^{\text {me }}$ petite octave; mais au moyen d'une patte on peut maintenant très bien donner l'Ut et même le Si. Avec toutes les clefs qui sont aujourd'hui adaptées à cet instrument, on peut monter jusqu'à l'Ut de la $5 .{ }^{\text {me }}$ petite octave.

Etendue générale de la flûte:

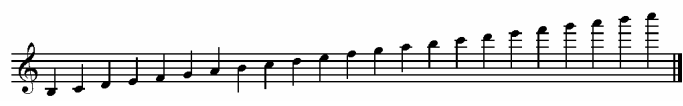

Il faut observer que la flûte possède dans son étendue tous les tons et demi-tons, (ce qui existe aussi pour tous les instrumens à vent, ou nous n'avertirons pas du contraire;) les tons les plus hauts et les plus bas ne sont généralement pas usités dans l'orchestre, parceque la flûte, avec toutes ses clefs et sa patte, n'est pas encore
CHAPTER IV. Wind instruments.

\section{THE FLUTE}

The use of the flute is very widespread-it is an instrument appopropriate for any kind of music. Its range was from D of the second small octave to A of the fourth small octave; but with the use of a footjoint one can now easily produce $\mathrm{C}$ and even B. With all the keys that have been attached to this instrument, the range is extended up to $\mathrm{C}$ of the fifth small octave.

General range of the flute:

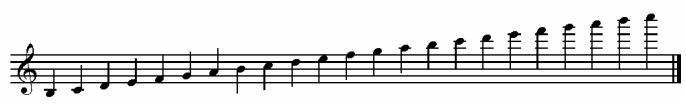

It is necessary to observe that the flute can play all the tones and semitones in its range (this is true for all wind instruments unless otherwise noted). The highest and lowest tones are generally not used in the orchestra because this flute, fitted with all its keys and its footjoint, is not yet used everywhere. Its range in orchestral works 
employée partout; son étendue pour

l'orchestre est:

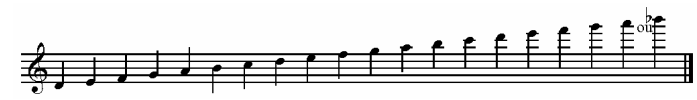

La musique pour la flûte est toujours écrite sur la clef de Sol 2. ${ }^{\text {me }}$ ligne, aussi l'effet des sons est-il absolument celui de la clef de Sol. Les morceaux avec dièzés sont les plus faciles à exécuter, on peut y ajouter ceux avec peu de bémols; mais avec cinq ou six dièzés la difficulté augmente déjà; enfin les morceaux avec 4 a 6 bémols sont ceux qui en offrent le plus; toutefois, si le mouvement n'est pas trop précipité, ils ne sont pas inexécutables.

La plupart des trilles se produisent très purement. Les notes plus graves que Ré ne peuvent s'employer que dans un pianissimo des sutures instrumens à cause de leur faiblesse, mais alors elles sont souvent d'un effet fort agréable. ${ }^{107,108}$ Il y a deux flûtes dans l'orchestre, une première et une seconde, qui dans les tutti is:

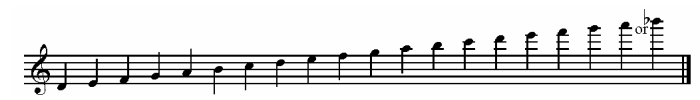

The music for the flute is always written on the treble clef; the aural effect is exactly that of the treble clef. Pieces with key signatures that include sharps are easiest to play; pieces containing a few flats are also possible, but the difficulty level increases with five or six sharps. Finally, pieces with four to six flats are those which offer the greatest difficulty; however, if the tempo is not too quick, they are not impracticable.

Most trills are produced in a very pure manner. The notes lower than $D$ can only be used in a pianissimo by other instruments, due to the weakness of those notes tones, but however they often have a very pleasant effect.

Two flutes, a first and second, are used in the orchestra. In loud tutti sections, they 
forte marchent ordinairement dans le haut par distances de tierces, sixtes et autres intervalles semblables. Comme elles sont d'habitude plus hautes que le premier violon, il faut prendre garde qu'elles ne forment avec lui des progressions désagréables ou défendues par les règles de la composition. C'est surtout la première flûte qui est la plus sensible à l'oreille. Si la mélodie doit être très forte, les deux flûtes peuvent aller à l'unisson, ce qui, d'ordinaire, forme alors l'octave supérieure du violon.

Il faut se garder des solos trop fréquens [sic] des deux flûtes en tierces ou sixtes, parcequ'ils sont d'un effet commun; mais la première flûte peut souvent servir au solo.

Lorsque les flûtes ont des sons prolongés en même tems que d'autres instrumens à vent, il ne faut pas les faire descendre plus que parceque les sons plus bas étant trop faibles, se perdraient dans usually occupy the upper register with intervals of thirds, sixths and other similar intervals. As the flutes are usually higher than the first violin, one must take care that they do not form progressions (with the first violin) which are unpleasant or violate the rules of the composition. The first flute is definitely the most audible. If a melody must be very loud, the two flutes can play in unison, which usually forms an octave higher than the violin's.

One should avoid writing too many solos for the two flutes in thirds and sixths because they produce a vulgar effect, but the first flute can often be used in solos.

When the flutes have sustained tones along with other wind instruments, one must not allow them to go lower than weak and would be lost in the harmony, 
l'harmonie, et que les intervalles des flûtes paraîtraient manquer entièrement.

Dans des tons qui ne sont pas trop difficiles, on peut faire avec vitesse des roulades, trilles et autres figures.

Au moyen du coup de langue le même son peut aussi être produit plusieurs fois de suite et assez rapidement, ce qui, du reste, existe dans Presque tous les instrumens à vent; cependant, il ne faut pas que cet effet soit trop répété ni trop prolongé, car des passages tells que:

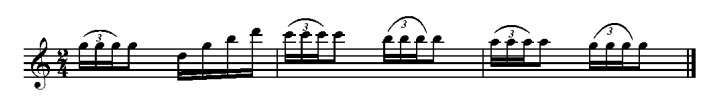

Ont trop de ressemblance avec la trompette, et d'autres, comme:

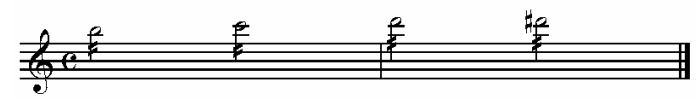

fatiguent trop l'artiste.

Dans les morceaux de musique où tous les genres d'instrumens ne sont pas employés, on n'introduit souvent qu'une seule flûte. Pour produire avec cette seule flûte un bon effet dans la musique militaire, il faut la and the flutes' intervals would seem to be lost entirely.

In keys that are not too difficult, one can perform roulades, trills, and other figures very quickly.

Through the use of tonguing, the same pitch can also be repeated rather rapidly: moreover, this is true of almost all of the wind instruments. However, this effect must be neither repeated nor prolonged too much, because passages such as:

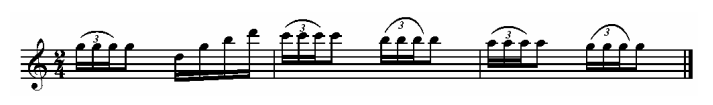

resemble too strongly those of the trumpet and other passages such as:

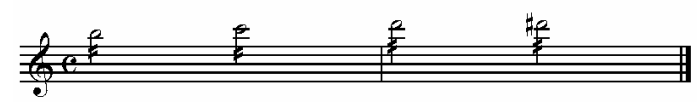

frequently tire the artist.

A solo flute is often introduced in pieces of music which do not employ all categories of instruments. To use this solo flute to good effect in military music, it must be paired in solos with another 
réunir en solos avec un autre instrument. instrument.

Dans les tutti on fait naturellement jouer la In tutti passages, one naturally uses the flûte, mais elle est tellement étouffée par flute, but it is muffled so much by the les autres instrumens, qu'on ne la others instruments that it is not noticed at remarque pas du tout. Aussi dans une all. Therefore, it cannot be used for solos marche, ne peut-on pas l'employer pour in a march; flutes are desirable only in des solos, ils ne sont applicables qu'à des calmer contexts where its less penetrating occasions plus calmes où les sons les sounds add to the effect of the ensemble.

moins perçans [sic] ajoutent en quelque

sorte à l'effet de l'ensemble.

\section{LA FLÛTE TIERCE ${ }^{109}$}

A la place de la flûte que nous venons de décrire, on se sert dans la musique militaire, mais rarement dans l'orchestre, de la flûte tierce dont les tons sont d'une tierce mineure plus élevés que dans la flûte ordinaire.

Son étendue est la même d'après les notes
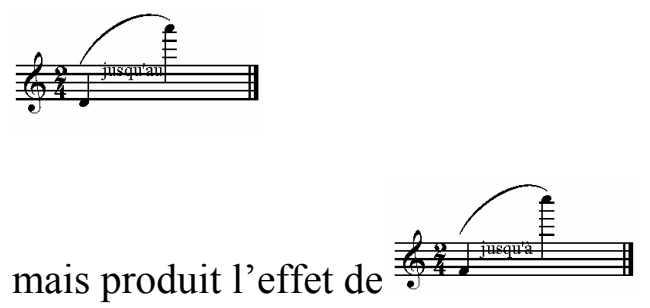

C'est pour cette raison que son étendue
Its written range is the same as:

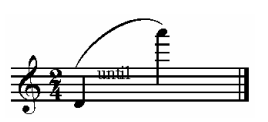

but produces the following effect:

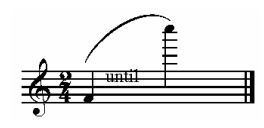

For this reason, its range starts with $\mathrm{F}$ of 
commence proprement au $\mathrm{Fa}$ de la 2. ${ }^{\text {me }}$

petite octave, et s'élève jusqu'à l' $U t$ de la

5. ${ }^{\text {me }}$ petite octave.

On peut se servir de cette flûte lorsque les

morceaux de musique sont écrits dans les

tons suivants: $U t$ majeur, $F a$ majeur, $S i b$

majeur, Mi b majeur, Lab majeur, Réb

majeur, ou dans leurs tons relatifs mineurs.

Tous ces morceaux doivent être écrits une

tierce mineure plus bas; Exemple:

Manière d'écrire: Effet produit:

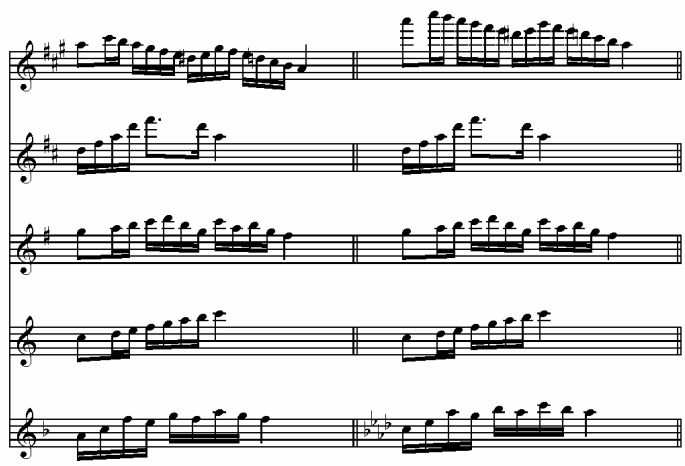

On n'emploie guère qu'une seule de ces

flûtes, rarement deux.

Malgré le bon effet qu'elle produit dans la musique guerrière, $\mathrm{il}$ arrive quelquefois qu'on ne s'en sert pas du tout. the second small octave, and extends up

to $\mathrm{C}$ of the fifth small octave.

One can use this flute in pieces of music that are written in the following keys: $\mathrm{C}$ major, $\mathrm{F}$ major, $\mathrm{B} b$ major, $\mathrm{E} b$ major, $\mathrm{A} b$ major, $\mathrm{D} b$ major, or in their relative

minors.

All these pieces should be written a minor third lower; for example:

Notated: $\quad$ Sounding:

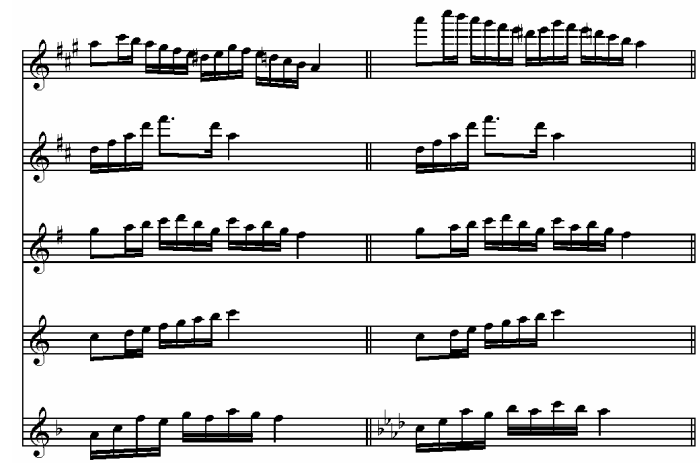

When this type of flute is used, one

generally used only one; the use of two is rare.

Despite the good effect that the tierce flute produces in military music, it sometimes is not used at all. 


\section{PETITE FLÛTE A L'OCTAVE (piccolo)}

Par cette dénomination on désigne un genre de flûte dont l'étendue s'élève très

haut, et qui s'emploie dans différens tons.

L'étendue, d'après les notes, est la même

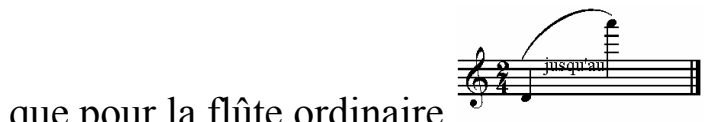

mais l'effet est d'une octave plus haut.

Exemple.

Manière d'écrire: Effet produit:

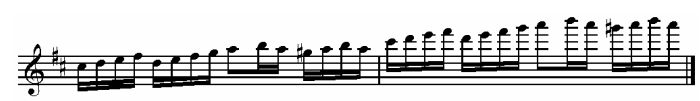

Ainsi qu'avec la flûte ordinaire on exécute facilement les tons avec dièzés et ceux avec peu de bémols.

Il faut éviter autant que possible d'écrire plus bas que parceque les tons plus bas manquent de timbre et ne font pas d'effet dans la masse des instrumens.

Une seconde espèce est la petite flûte en Mi $b$ qui est encore d'un demi-ton plus

\section{OCTAVE PICCOLO (piccolo)}

This term denotes a kind of flute whose range rises very high, and is used in different keys. The written range is the same as the ordinary flute

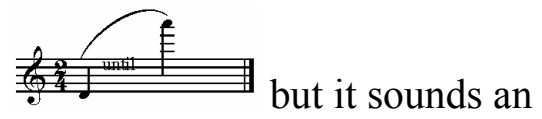

octave higher. For example.

Notated: $\quad$ Sounding:

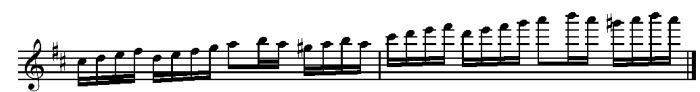

As with the ordinary flute, keys with

sharps as well as those with few flats are easily performed.

It is necessary to avoid, as much as is

possible, writing pitches lower than because the lower pitches lack timbre and can not be heard in an ensemble.

A second type of piccolo is the piccolo in $\mathrm{E} b$ which is pitched a semitone higher 
élevée que la précédente; son étendue est la même selon les notes,

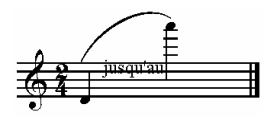

mais l'effet est d'une

octave et un demi-ton plus élevé que dans

la flûte ordinaire; par Ex:

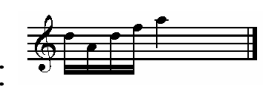

fait sur la flûte en Mi b l'effet de:

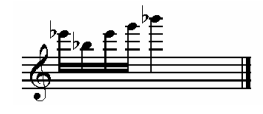

Les morceaux sont donc en $\mathrm{Si} b$ majeur où elle joue La majeur, en Mib majeur où elle joue Ré majeur, en La $b$ majeur où elle joue Sol majeur, en Réb majeur où elle joue Ut majeur, en Sol b majeur où elle joue Fa majeur $\&^{\text {it }} \&^{\text {it }}$.

Lite troisième espèce est la flûte tierce à l'octave ou petite flûte en Fa qui est d'une octave et d'une tierce mineure plus élevée que la flûte ordinaire; ou bien d'une octave plus élevée que la grande flûte tierce; son

étendue est selon les notes:

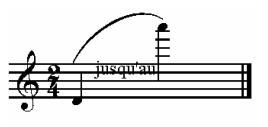

than the first piccolo we have mentioned; its written range is the same:

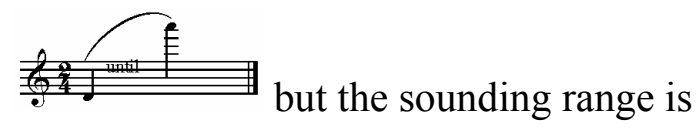
an octave plus one semitone higher than that of the ordinary flute; for example:

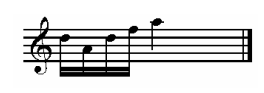

played on the flute in $\mathrm{E} b$ produces the

following effect:

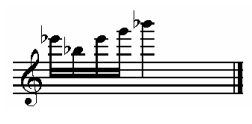

The pieces are thus in $\mathrm{B} b$ major when the instrument in A major, in $\mathrm{E} b$ major when it plays D major, in A b major when it plays $\mathrm{G}$ major, in $\mathrm{D} b$ major when it plays $\mathrm{C}$ major, in $\mathrm{G} b$ major when it plays in $\mathrm{F}$ major and the like.

A third type is the flûte tierce à l'octave, or piccolo in $\mathrm{F}$, which is an octave and a minor third higher than the ordinary flute; or an octave higher than the tierce flute;

its range is as follows:

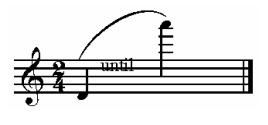


mais fait l'effet de:

Les morceaux de musique peuvent être but produces:

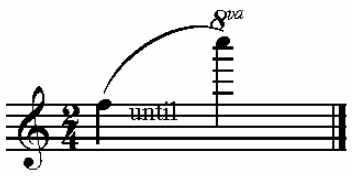

Pieces of music using this flute can be

écrits dans le même ton que pour la grande written in the same key as the tierce flute;

flûte tierce; savoir Ut majeur, Fa majeur, namely $\mathrm{C}$ major, F major, $\mathrm{B} b$ major, $\mathrm{E}$ b

Si $b$ majeur, Mi m majeur, La $b$ majeur, major, $\mathrm{A} b$ major, and $\mathrm{D} b$ major.

Réb majeur.

Voici un exemple pour démontrer plus

Here is an example which more clearly

clairement la proportion réciproque:

demonstrates the reciprocal proportion:
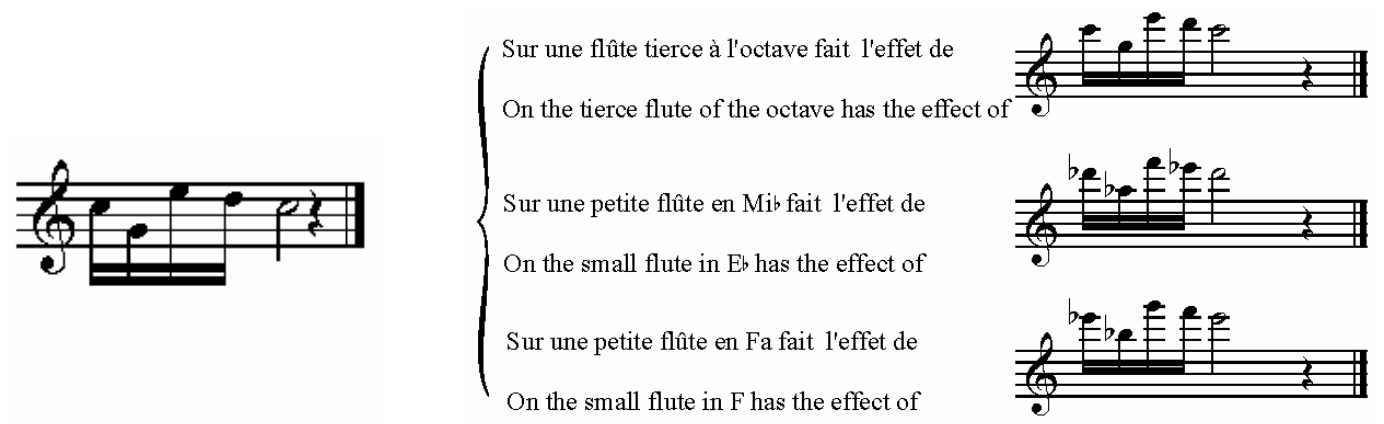

A cause de la difficulté de plusieurs tons

on choisit chaque fois la flûte la plus

propre à leur exécution, mais il ne faut pas

omettre de la designer dans la partition, ou

dans la partie détachée, par exemple: petite

flûte à l'octave, petite flûte en $\mathrm{Fa}$, petite

flûte en Mib.

Comme les tons en Ut majeur, Sol majeur,
Because of the difficulty involved in the

performance of several keys, one chooses

the flute best suited for the execution of

each piece, but one should not forget to

specify the type of flute in the score or in the part, for example: piccolo, piccolo in $\mathrm{F}$, piccolo in $\mathrm{E} b$. 
Ré majeur, La majeur, Mi majeur, Fa

majeur, Si $b$ majeur, et leurs tons relatifs

mineurs peuvent être rendus par la petite

flûte à l'octave, qui donne le ton exprimé

par la note, ce n'est qu'en Mib qu'on

prend la petite flûte en Fa que, alors, joue

en Ut; par exemple:

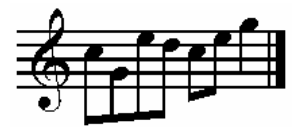

qui fait l'effet de:

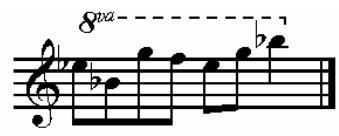

Ou la petite flûte en Mi $b$ qui joue alors en

Ré majeur; exemple:

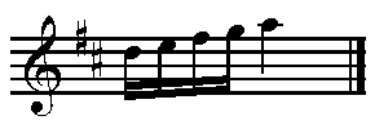

Effet produit:

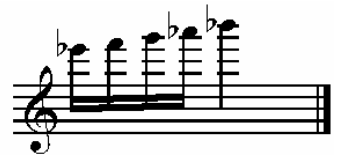

De même on prend la petite flûte en Mib pour le ton de La $b$ qui fait alors Sol majeur; pour Réb majeur qui fait Ut majeur, pour Sol $b$ majeur qui fait $\mathrm{Fa}$ majeur.

Il est cependant à conseiller de composer
A major, E major, F major, B $b$ major, and their relative minors can be played by the piccolo, whose aural notes are the same as those written in the score. Only in the key of $\mathrm{E} b$ does one use the piccolo in F which, in turn, plays in C. For example:
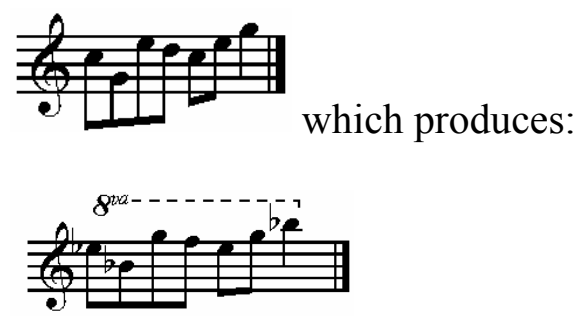

Or the piccolo in $\mathrm{E} b$ which then plays in D major. For example:
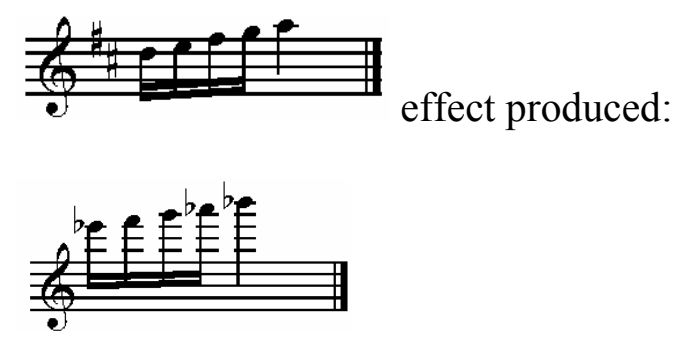

Similarly, the tierce piccolo is used in $\mathrm{E} b$ for the key of $A b$, which then produces $\mathrm{G}$ major; in $\mathrm{D} b$ major $\mathrm{C}$ major is produced; and in $\mathrm{G} b$ major $\mathrm{F}$ major is produced.

It is, however, advised to compose simply 
simplement pour les tons difficiles, et de

s'en tenir à la petite flûte à l'octave,

parceque les deux autres espèces de flûtes

ne se rencontrent point partout.

Dans la musique militaire il n'y a

ordinairement qu'une petite flûte qui

forme avec la petite clarinette la partie la

plus élevée, ce qui frappe beaucoup

l'oreille. C'est pourquoi il faut apporter

beaucoup de soin à leurs progressions.

Dans l'orchestre on peut utiliser la petite

flûte, à cause de son timbre perçant, pour

les marches et autres morceaux de ce

caractère.

La plupart du tems elle double les autres parties à l'octave; quelquefois, cependant, elle peut suivre une marche particulière.

Ce qui a été dit pour la grande flûte, relativement au coup de langue, est

applicable à celle-ci; elle exécute

facilement les trilles et autres figures rapides.

Il faut encore observer qu'on ne s'en sert for the difficult keys, and to confine

oneself to the octave piccolo, because the two other types of flutes are not found everywhere.

In military music there is usually only one piccolo which, with the small clarinet, forms the highest part, which is quite striking to the ear. This is why it is necessary to take much care with their progressions.

In the orchestra one can use the piccolo, because of its piercing tone, for marches and other pieces of this character.

Most of the time, it doubles the other parts by octaves; sometimes, however, it can follow a particular style. What was said earlier about the concert flute, relative to tonguing, is applicable to the piccolo as well; it easily plays fast trills and other figures.

It still also is observed that one seldom 
que rarement dans l'orchestre, pour que l'effet en demeure piquant. Quelquefois on introduit jusqu'à deux petites flûtes dans l'orchestre, mais le plus souvent on se sert d'une grande et d'une petite.

Outre les trios espèces ci-dessus désignées, il y a encore une petite flûte en Sol qui est d'un ton plus élevée que la petite flûte en $\mathrm{Fa}$; mais on ne s'en sert plus que rarement, en Allemagne, dans la musique militaire.

Il existe aussi une flûte appelée flûte d'amour qui est d'une tierce mineure plus basse que la flûte en Ré décrite, et dont l'effet est le suivant:

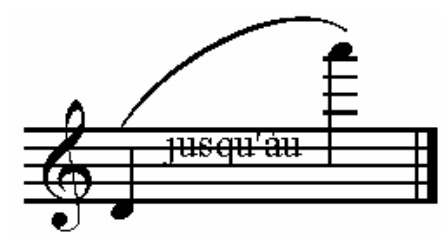

ce qui fait:

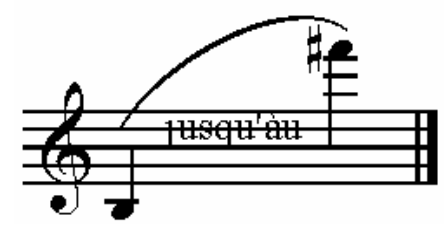

Une autre espèce est la flûte quarte qui est une quarte plus haute que la flûte ordinaire makes use of the piccolo in the orchestra, so that it retains its striking effect.

Sometimes as many as two piccolos are introduced into the orchestra, but more often one flute and one piccolo are used. In addition to the three types designated above, there is also a piccolo in $\mathrm{G}$ which is a tone higher than the piccolo in F; but it is only rarely used today - in military music in Germany.

There is a flute called flute d'amour which is a minor third lower than the flute in D described previously, and its effect is as follows:
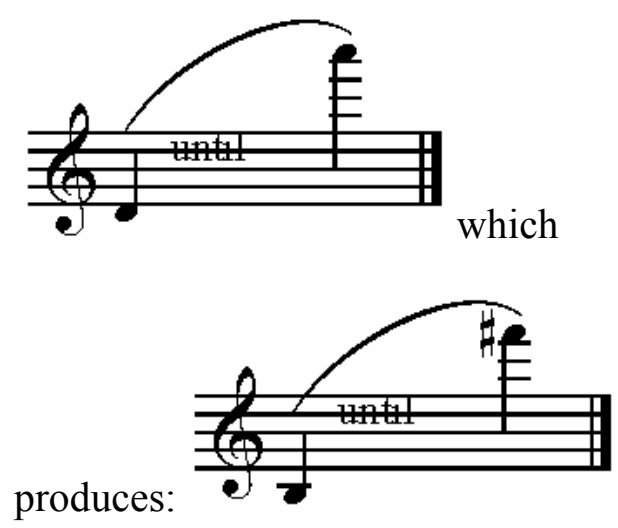

Another type is the fourth flute, which is a fourth higher than the ordinary $\mathrm{D}$ flute: 
en Ré:
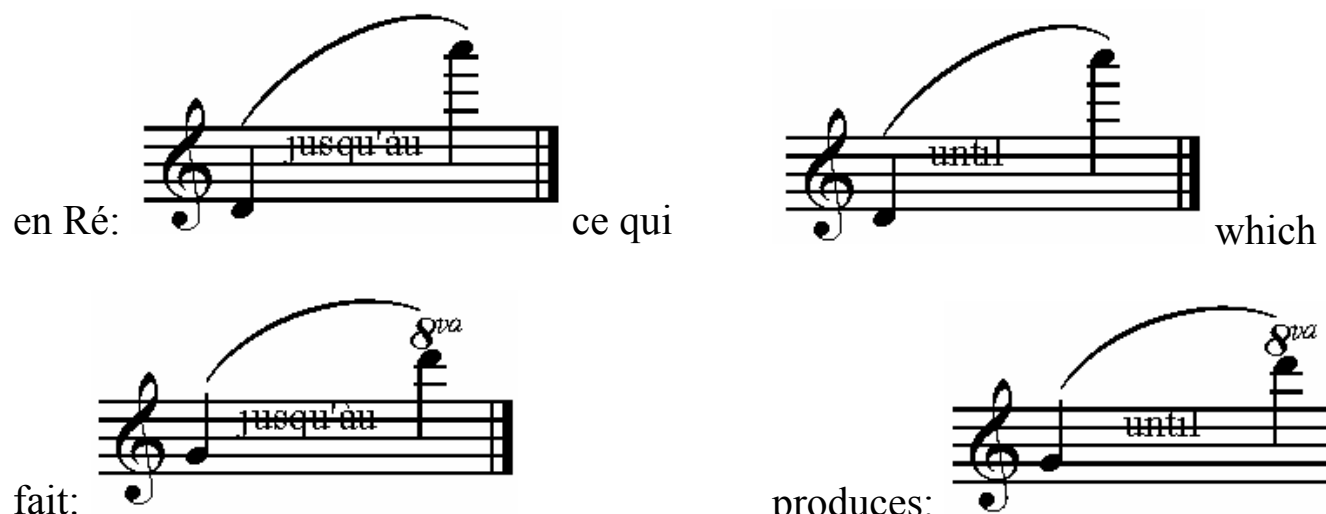

Enfin une flûte nommée flûte à canne ou

Czakan, son étendue est:

Czakan has a range of:

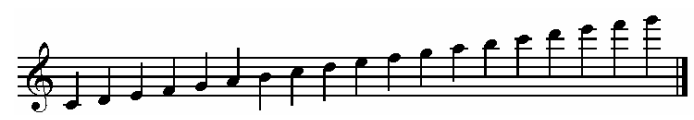

Tous ces tons peuvent être dièzés ou

bémolises, et l'effet produit est plus bas

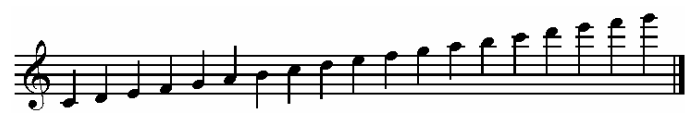

All these tones can be sharped or flatted, and the produced effect is a major third

d'une tierce majeure; ainsi la gamme d'Ut

fait l'effet de la gamme de Lab majeur.

Exemple:

Ab major scale.

For example:
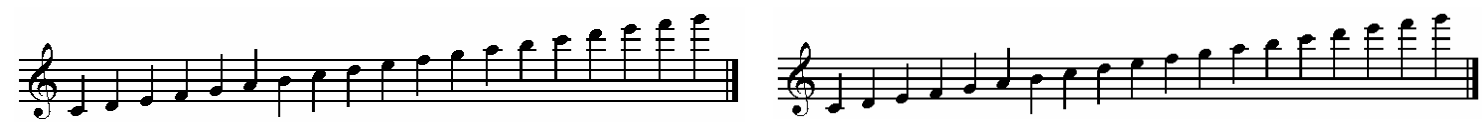

On this flute, produces:

Fait sur cette flûte:
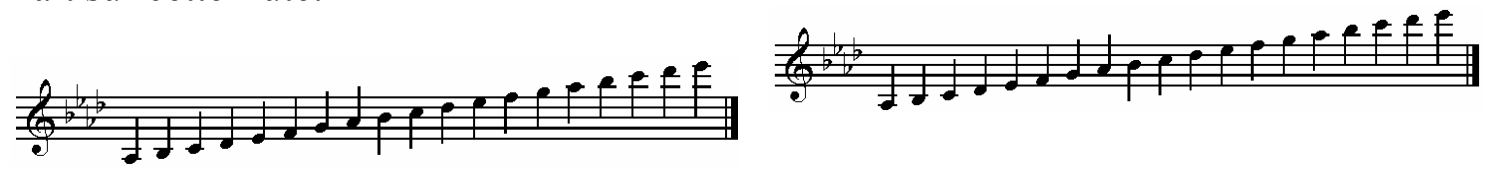

Les demi-tons les plus bas et les plus

The highest and lowest semitones are

élevés sont rarement justes et il faut les

seldom in tune and they should be

éviter soigneusement.

carefully avoided.

On a des, Méthodes pour ce genre de flûtes There are method s for this type of flute 
de Klingenbruner et Krämer.

On a des Méthodes pour la flûte de M.M. Bayr, Berbiguier, Devienne, Drouet,

Froelich, Furstenau, Hugot, Wunderlick, Muller, Quanz, Tromlitz, Vanderhagen,

Cambini, Tulou, Walckiers et autres. ${ }^{110}$

Autrefois dans les musiques militaires on se servait encore d'une petite flûte nommée fifre qui n'était pas tout-a-fait à l'octave comme la petite flûte. De sorte que, lorsque l'harmonie était en Fa, le fifre jouait en Sol; et quand l'harmonie était en Ut, le fifre jouait en Ré. On s'en servait dans la troupe pour accompagner les caisses. Le fifre n'a pas de clefs, c'est pourquoi son doigté différait pour certaines notes de celui de notre petite flûte ordinaire.

Le flûtet moderne ou flûte de tambourin est également note sur la clef de Sol $2 .{ }^{\text {me }}$ ligne, mais les tons qu'il produit sont encore d'une octave plus hauts que ceux de la petite flûte, et ainsi de deux octaves by Klingenbruner and Krämer.

There are methods for the flute by Mr. Bayr, Berbiguier, Devienne, Drouet, Froelich, Furstenau, Hugot, Wunderlick, Muller, Quanz, Tromlitz, Vanderhagen, Cambini, Tulou, Walckiers and others. Formerly, in military music, a small flute called the fife was used, which was not completely on octave, like the piccolo.

For example, when the harmony was in $\mathrm{F}$, the fife played in G; and when the harmony was in C, the fife played in D. It was used by the troops to accompany the drums. The fife does not have keys. Because of this, for certain notes it's fingerings differed from that of our ordinary piccolo.

The modern flûtet or tambourine flute is also notated on the treble clef, but the tones it produces are an octave higher than those of the piccolo, and thus two octaves higher than the ordinary concert 
plus hauts que la grande flûte ordinaire. flute.

Son étendue notée est:

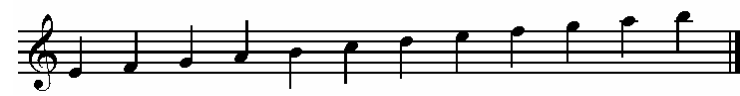

L'effet est donc sur la petite flûte à

l'octave:

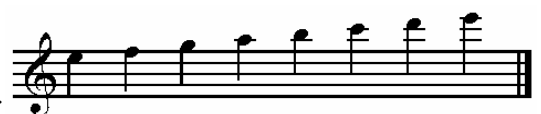

et sur la grande flûte:

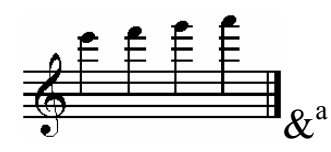

en montant, tons qu'on n'y peut plus

produire.

On fait sur le flûtet tous les tons et demi-

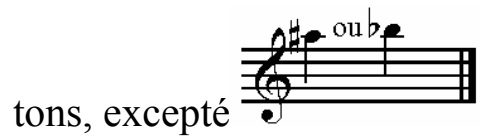

Les tons les plus favorables du flûtet sont:

Ré majeur, La majeur, La mineur; Sol

majeur; Mi mineur; Ut majeur; et Mi

majeur.

Autrefois on avait encore une espèce de

flûte qui ne s'embouchait pas

horizontalement, mais bien verticalement

comme le hautbois et la clarinette, et qu'on

appelait flûte douce ou flûte à bec. Elle
Its notated range is:

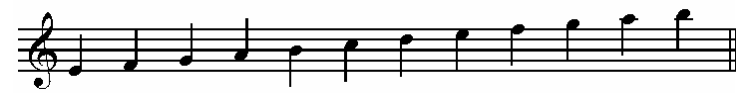

the resulting range produced on the

piccolo is thus:

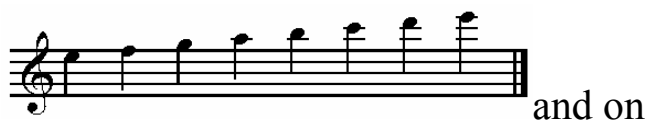

the concert flute:

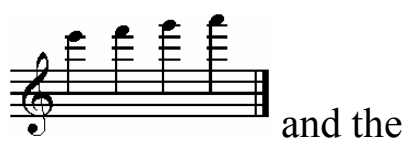

like ascending: tones that can no longer

be produced on the modern flute.

All the tones and semitones on the flûtet

are played except

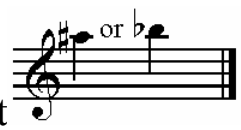

The keys most favorable for the flûtet are:

D Major, A major, A minor, G major, E

minor, C Major, and E major.

Formerly, there was also a type of flute

which was not blown horizontally, but

vertically, like the oboe or the clarinet,

which one called the flute douce, or

recorder. Its range was from $\mathrm{F}$ of the 
s'étendait du Fa de la 2. ${ }^{\text {me }}$ petite octave au

Sol de la $4 .{ }^{\text {me }}$ petite octave, par tous les

tons de la gamme diatonique et

chromatique.

On l'écrit comme ci-dessous:

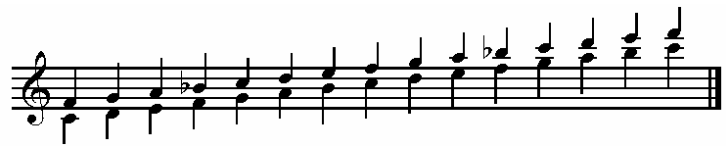

Mais la note Ut fait l'effet d'un Fa, le Ré

d'un Sol, et ainsi de suite.

On en faisait de plusieurs dimensions.

1. ${ }^{\circ}$ La flûte basse dont l'étendue était

depuis Fa de la grande octave jusqu'à Ré

de la $2{ }^{\text {me }}$ petite octave.

2. ${ }^{\circ}$ La flûte tenor dont l'étendue était

depuis Si b de la grande octave jusqu'à Sol

de la $2 .^{\text {me }}$ petite octave.

3. ${ }^{o}$ La flûte alto qui était juste d'une

octave plus élevée que la flûte basse.

4. ${ }^{\circ}$ La flûte discant (soprano) qui est celle

que nous avons d'écrite la première.

LE FLAGEOLET

Le flageolet tire son origine de la flûte à second small octave to $G$ of the fourth small octave, with all the tones of the diatonic and chromatic scale.

It is written as below:

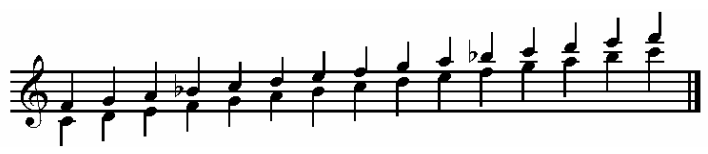

But the written note $\mathrm{C}$ produces $\mathrm{F}$; D

produces G, and so on.

The flute douce was made in several sizes.

1. The bass, whose range was from $F$ of the great octave to D of the second small octave.

2. The tenor, whose range was from $\mathrm{B} b$ of the great octave to $\mathrm{G}$ of the second small octave.

3. The alto, which was exactly an octave higher than the bass.

4. The discant (soprano) flute, which is the first flute described in this section. FLAGEOLET The flageolet draws its origin from the 
bec; ainsi qu'elle, il n'est pas tenu

horizontalement, mais bien comme le

hautbois ou la clarinette; les sons de cet instrument sont à l'unisson avec ceux de la petite flûte, mais ils sont bien plus doux. étendue du flageolet ordinaire est:

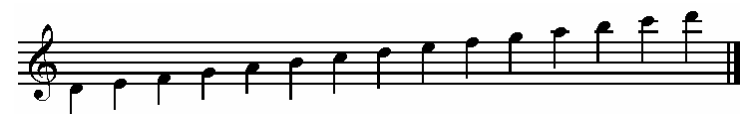

chromatiquement, mais l'effet en est d'une octave plus élevé. Les nouveaux flageolets ont l'étendue suivante:

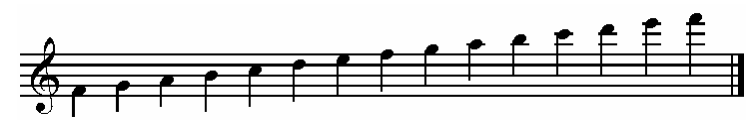

chromatiquement, l'effet en est

naturellement aussi plus haut d'une octave.

Les tons les plus faciles du flageolet

ordinaire, sont: Fa majeur; La mineur; Si b

majeur; Sol mineur; Mi b majeur; $\&^{\mathrm{a}}$.

Il faut éviter, autant que possible, les tons

avec beaucoup de dièzés et de bémols.

On a aussi maintenant un flageolet en La qui sert principalement pour la musique de danse. On l'écrit une quinte plus bas que le ton ordinaire du violon ou celui du piano- recorder; like the recorder, the flageolet is not held horizontally, but vertically like the oboe or the clarinet. The sounds of this instrument are the same as the piccolo, but they are much softer. The range of the ordinary flageolet is:

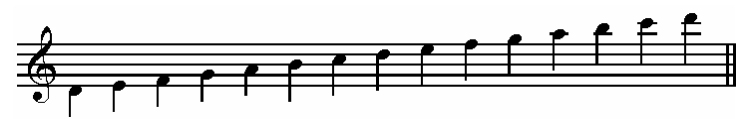

chromatically, but the effect is an octave

higher. The new flageolets have the

following range:

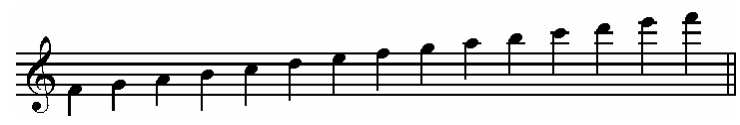

chromatically, the effect they produce is

naturally also an octave higher.

The easiest keys of the ordinary flageolet

are: $\mathrm{F}$ Major, $\mathrm{A}$ minor, $\mathrm{B} b$ major, $\mathrm{G}$

minor, $\mathrm{E} b$ major, and the like.

Keys with many sharps and flats must be avoided as much as possible.

There is now also a flageolet in the key of A which is useful mainly for dance music. It is written a fifth lower than the ordinary key of the violin or that of the 
forté; par exemple: si le morceau est en Mi majeur, le flageolet en La le joue en La; si le morceau est en Sib majeur, il le joue en Mib majeur; si le morceau est en La, il joue en Ré, et ainsi de suite.

Violon

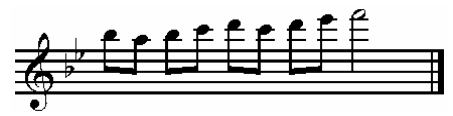

Flageolet en $L a$

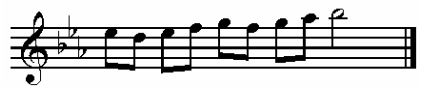

Violon

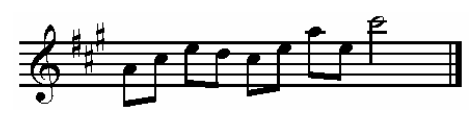

Flageolet en $L a$

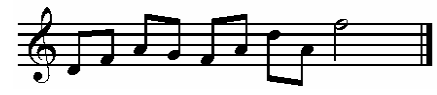

L'étendue du flageolet en La est:

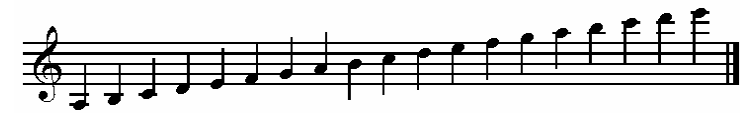

Chromat: mais l'effet produit est d'une quinte plus élevé:

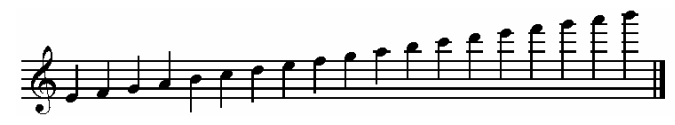

Chromat:

Ainsi donc, comme on l'a déjà dit, les piano-forte. For example: if the piece is in E major, the flageolet in A plays it in $\mathrm{A}$; if the piece is in $\mathrm{B} b$ major, it plays it in $\mathrm{E} b$ major; if the piece is in $\mathrm{A}$, it plays in $\mathrm{D}$, and so on.

Violin

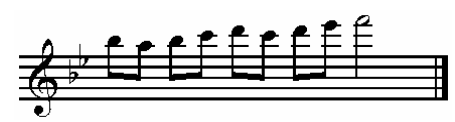

Flageolet in A

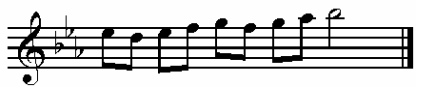

Violin

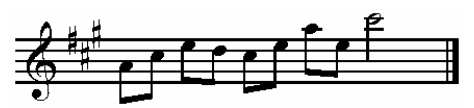

Flageolet in A

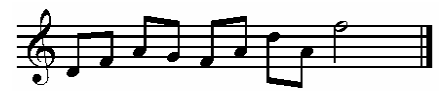

The range of the flageolet in A is:

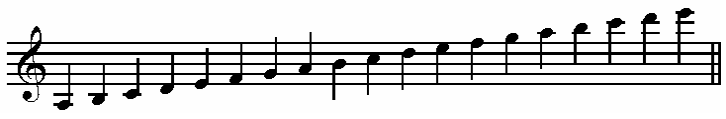

Chromatically: but the produced sound is a fifth higher:

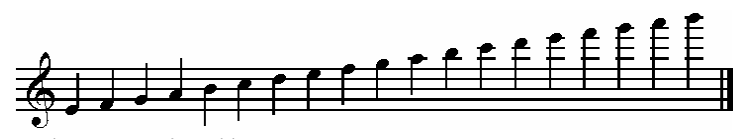

Chromatically

Thus, as noted above, the notes of the 
notes du flageolet en La sont transposes cinq notes plus bas que les notes du violon ou du hautbois, ce qui donne la clef d'Ut, $2 .{ }^{\mathrm{me}}$ ligne, pour le flageolet.

Mr. Rubner a publié une gamme pour le flageolet en La.

Un artiste nommé Bembridge a aussi

inventé un flageolet double. ${ }^{111}$

\section{LE HAUTBOIS.}

Le hautbois, instrument utile à toute espèce de musique, est note sur la clef de Sol, 2. ${ }^{\text {me }}$ ligne; il est à l'unisson avec le violon; son étendue ordinaire est de l'Ut de la $2 .{ }^{\text {me }}$ petite octave, au Ré, Mi, ou Fa de la $4{ }^{\text {me }}$ petite octave, et l'effet en est réel ainsi que l'indiquent les notes

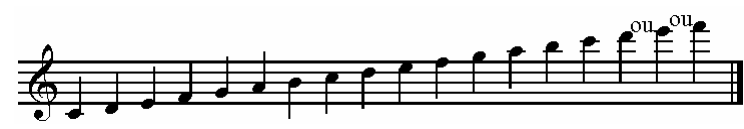

Chromatiquement.

Les notes les plus hautes ainsi que les plus basses doivent être employées prudemment, parcequ'elles sont difficiles à intonner [sic] et produiraient même un effet comique dans des morceaux très flageolet in A are transposed five notes lower than the notes of the violin or the oboe, which gives the flageolet the $\mathrm{C}$ clef, second line.

Mr. Rubner published a scale for the flageolet in A.

An artist named Bembridge has also invented a double flageolet.

\section{THE OBOE}

The oboe, an instrument useful in any type of music, is notated on the treble clef. It is in unison with the violin. Its ordinary range is from $\mathrm{C}$ of the second small octave, to D, E, or F of the fourth small octave, and the notes it produces are the same as:

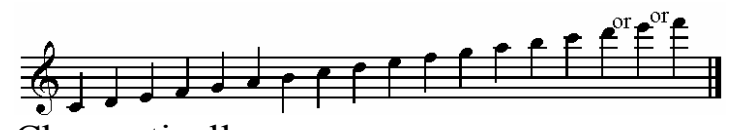
Chromatically.

The highest and lowest notes must be used wisely, because they are difficult to tune and would actually produce a comic effect in very fast pieces. 
rapides.

L'Ut dièze le plus grave est très difficile à The lowest $C \#$ is very difficult to play on exécuter sur le hautbois ordinaire; il en est the ordinary oboe; the same is true for the de même du Sol dièze et du La bémol de la $\mathrm{G} \#$ and the $\mathrm{A} b$ of the second small 2.me petite octave, s'ils se répètent octave, if they are repeated in alternation plusieurs fois de suite avec d'autres tons with other keys, for example: qui les précèdent ou les suivent immédiatement; par exemple:

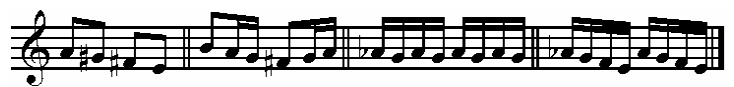

Par la même raison cette difficulté subsiste aussi pour l'Ut\# et le Ré\# ou pour le Réb et le Mib de la $3 .^{\text {me }}$ petite octave; par

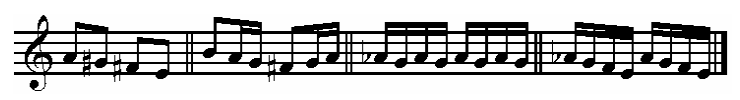
exemple:

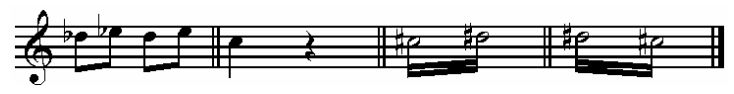

En général, on évite, autant que possible, l'Ut alterné avec le Sib de la $2 .{ }^{\text {me }}$ petite octave, de même que le Fa de la $3 .^{\text {me }}$ petite octave avec le Mi, parceque de pareils third small octave with the E, because passages forment une fourchette; par exemple:

Il faut donc composer plus simplement dans les tons. La majeur, Mi majeur, Si

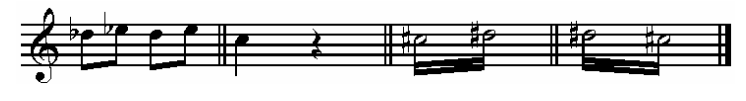

In general, one avoids as much as possible $\mathrm{C}$ alternated with $\mathrm{B} b$ of the second small octave, as well as F of the such passages form a forked fingering, for example:

It is thus necessary to use simpler compositions in the keys.A major, $\mathrm{E}$ 
majeur, Mi b majeur, Sib majeur, Mi b

majeur, La $b$ majeur, Ré majeur et leurs

tons relatifs mineurs car des passages tells

que:

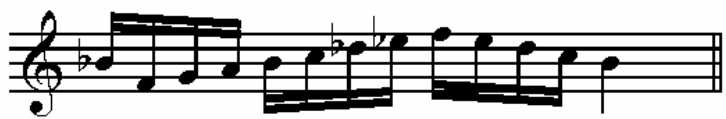

sont déjà inexécutables à moins que le

tempo ne soit très lent, et encore malgré

cela, ils font toujours un effet choquant;

par la même raison on ne peut pas exécuter

le trille suivant:

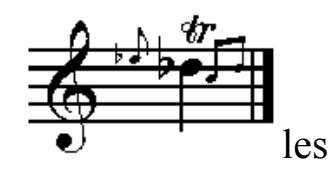

autres sont plus faciles.

Le hautbois est à l'unisson avec le violon, et comme nous l'avons déjà dit, il a

quelque ressemblance avec lui dans les

tons du medium; mais il doit être traité

tout différemment comme instrument à

vent, car des figures rapides qui sont d'une

exécution très facile sur le violon

deviennent très difficiles pour le hautbois.

En général il faut composer plus

simplement pour tous les instrumens à major, $\mathrm{B}$ major, $\mathrm{E} b$ major $\mathrm{B} b$ major, $\mathrm{A} b$ major, D major and their relative minor keys because of passages such as:

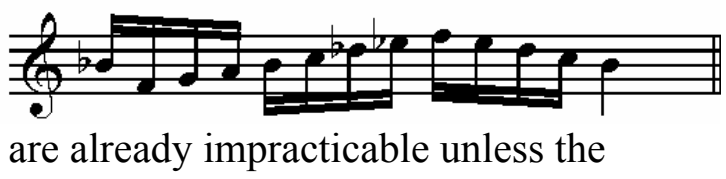

tempo is very slow, but in spite of that,

they always produce a shocking effect.

For the same reason, one cannot play the

following trill:

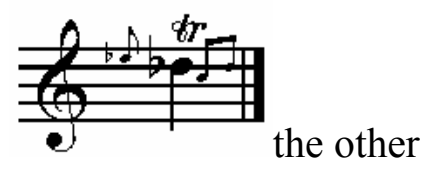

trills are easier.

The oboe plays in unison with the violin, and as we already said, it has some resemblance to the violin in the middle register; but as a wind instrument it must be treated very differently: fast figures which are very easy to play on the violin become very difficult for the oboe. In general, one must compose more simply for all orchestral wind instruments than for stringed instruments. 
vent de l'orchestre que pour les instrumens

à cordes.

Il y a dans l'orchestre un premier et un

second hautbois; il peut donc y avoir des

solos pour le premier seul ou pour les deux

à la fois, lesquels solos ne doivent

cependant pas être composes de beaucoup

de notes se succédant rapidement; au

contraire des sons isoles ou prolongés font

souvent sur cet instrument un effet

admirable, à cause de son timbre

particulier qui est toujours perçant, même

dans un orchestre complet.

Les tons du médium sont aussi d'un très

bon effet; c'est pour cette raison que les

intervalles qui ne doivent pas percer, il ne

faut pas les employer sur cet instrument

dont le son aigu sert au contraire fort bien

pour des septièmes ou autres tons qui

doivent dominer. ${ }^{112}$

Quant les deux hautbois marchent à de

petits intervalles et dans des tons élevés,

l'effet en est encore très agréable.
In the orchestra, there are a first and a second oboe; there can thus be solos for the first oboe alone or for both of them at the same time. However, these solos should not be composed of many notes following one another in rapid succession; on the contrary, isolated or sustained tones on this instrument often have an admirable effect, because of its distinctive timbre, which is always piercing, even in a full orchestra. The middle tones also have a very good effect; it is for this reason that the intervals should not piercing, in fact they should not be used on the oboe, whose high sound is extremely useful, on the contrary, for sevenths or other keys which must dominate.

When two oboes play in small intervals and in higher registers, the effect is still very pleasant. 
Ce qui a été dit du coup de langue, pour la flûte, peut aussi s'appliquer ici, et, des figures telles que:

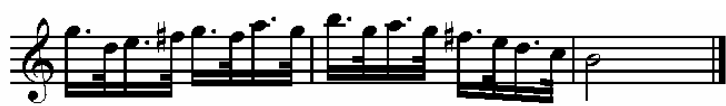

font quelquefois très bon effet.

Le hautbois va souvent à l'unisson avec la clarinette en Ut, mais son caractère tout différent de cet instrument, le rend plus propre à une marche particulière.

Nous avons des Méthodes pour le hautbois de Brod, Garnier, Schikhardt, Sellner, Vanderhagen, Froelich et autres.113

\section{LA CORNEMUSE. (Musette)}

Cet instrument à vent, quoique peu usité de mos jours, est connu de presque tout le monde; on le trouve encore entre les mains des mendians $[$ sic] et des bohémiens ambulans $[s i c]$; son étendue ordinaire est d'une neuvième, mais ceci à différens degrés de hauteur, parcequ'on employait
What was known as tonguing for the flute, can also apply here, and, in the figures such as:

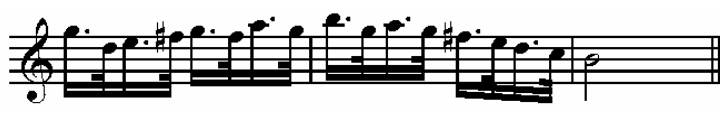

They sometimes produce a very good effect.

The oboe often plays in unison with the clarinet in C, but since it's the oboe's character is very different from this instrument, it is more appropriate for a particular style.

There are oboe methods by Brod, Garnier, Schikhardt, Sellner, Vanderhagen, Froelich and others.

\section{The Cornemuse}

This wind instrument, though not used these days, is known by almost everyone; one still finds it in the hands of beggars and the nomadic gypsies; its normal range is a ninth, but with different height degrees, because one uses up to five different sizes of cornemuses; the largest, 
jusqu'à cinq dimensions différentes; la plus grande s'étendait du Fa de la grande octave jusqu'au Sol de la petite octave, et la plus petite du Sib de la petite octave jusqu'à l'Ut de la $3{ }^{\text {me }}$ petite octave; avec les cinq espèces réunies nos ancêtres ont du produire une assez belle harmonie. La musette perfectionnée en France avait pour étendue:

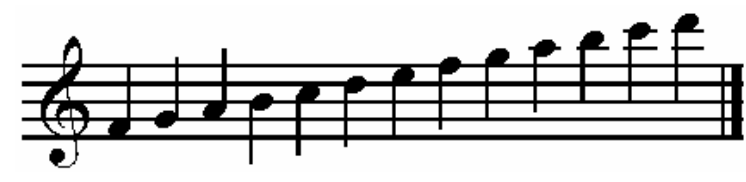

Et comprenait dans cette étendue tous les tons et demi-tons qu'on exécute au moyen de clefs adaptées à l'instrument. On écrivait pour la musette sur la clef de Sol $1{ }^{\text {re }}$ ligne; exemple:

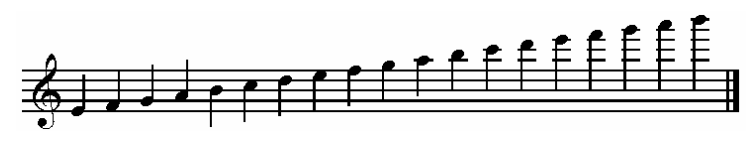

On a une Méthode pour la cornemuse ou musette de Hottetere. ${ }^{114}$ LE COR ANGLAIS. whose range is from $\mathrm{F}$ of the great octave to the $\mathrm{G}$ of the small octave, and smallest, from $B b$ of the small octave to $C$ of the third small octave; with all five types available to them, our ancestors must have produced a rather beautiful harmony.

The Musette, perfected in France, had a range of:

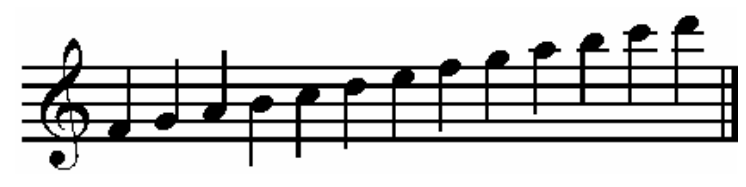

Included in this range are all the tones and semitones which one plays using keys affixed to the instrument. The Musette was written on the first line of the treble clef, for example:

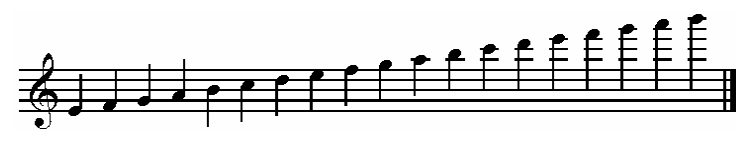

There is a Method for the bagpipe or haversack by Hottetere. THE ENGLISH HORN 
Le cor anglais n'est proprement qu'un hautbois agrandi; on peut le considérer comme l'alto du hautbois; il s'écrit bien sur la clef de Sol, mais l'effet produit est de cinq tons plus bas que le violon; il faut donc que le compositeur le note en conséquence; par exemple, si son morceau est en Ut majeur, il doit écrire pour le cor anglais en Sol majeur avec un dièze; si le morceau est en Fa majeur, il faut écrire en Ut majeur; lorsqu'on écrit en Sib majeur, il faut jouer en $\mathrm{Fa}$. C'est pour cette raison que cet instrument a toujours un bémol de moins dans les tons bémolisés, et dans les tons dièzés, toujours un dièze de plus que tous les autres instrumens.

L'étendue qu'on emploie généralement commencé du Fa de la première petite octave jusqu'au Sol ou La de la 3. ${ }^{\mathrm{e}}$ petite octave, tout au plus jusqu'au Si b.

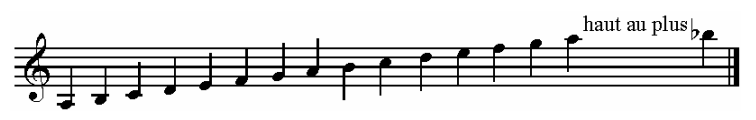

The English horn is just a larger version of the oboe; it can also be considered as viola of the oboe. Although it is written on the treble clef, the sound produced is five tones lower than the violin; thus, the composer must notate accordingly. For example, if the piece is written in $\mathrm{C}$ major, he must write in $\mathrm{G}$ major (with one sharp) for the English horn; if the piece is in $\mathrm{F}$ major, it will be written in $\mathrm{C}$ major for the English horn; when one writes in $\mathrm{B} b$ major, the English horn will be played in F. For this reason, this instrument always has one flat less in flatted keys, and in sharp keys, always one sharp more than all the other instruments.

The general range of this instrument is from $F$ of the first small octave to $G$ of the third small octave, and at most to B $b$.

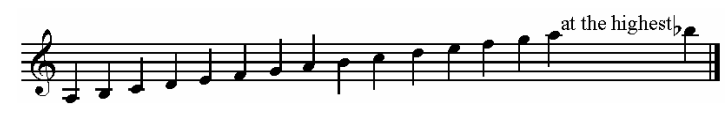


Mais comme toutes les notes pour cet

instrument sont écrites une quinte plus

haut que leur effet, l'étendue en notes

d'après lesquelles il doit jouer est désignée

comme suit:

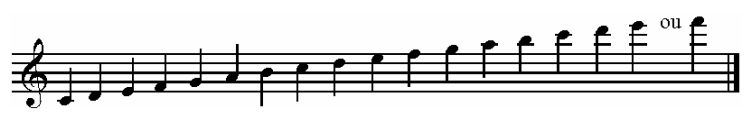

Les notes plus basses ne doivent être

employées qu'avec précaution,

parcequ'elles sont difficiles à faire et

produisent souvent un son bizarre; le

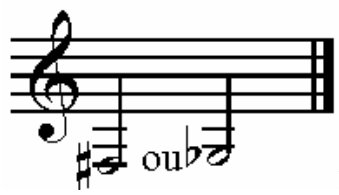

manque totalement;

tous les autres tons et demi-tons peuvent

s'exécuter; du reste ce qui a été dit

relativement au hautbois est encore

applicable au cor anglais, car il a, à peu

près le même doigté; par cette raison, un

passage tel que:

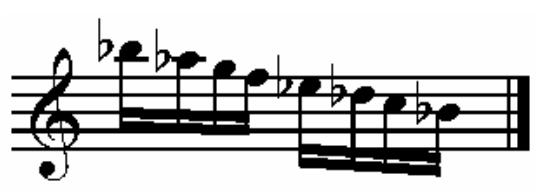

mais qui
Because all the notes for this instrument

are written a fifth higher than their

sounding pitch, the range in the notes it

must play is indicated as follows:

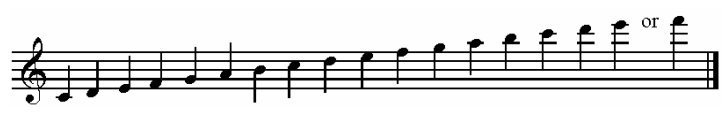

The lower notes should be used

judiciously, because they are difficult to

play and often produce an odd sound;

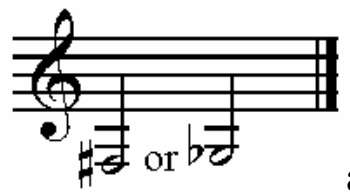

are missing

completely. All the other tones and

semitones can be played, for the rest,

what has been said relative to the oboe is

also applicable to the English horn,

because it has approximately the same

fingering; for this reason, a passage such

as:

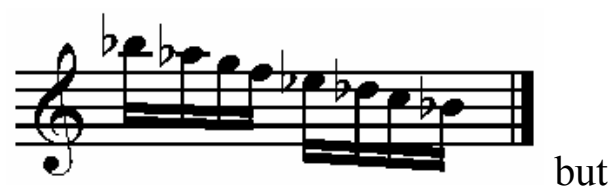

which produces the effect of:

fait l'effet de: 


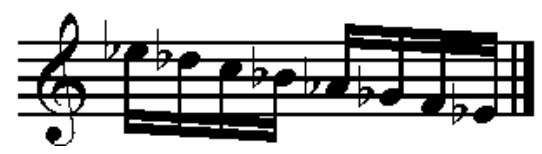

inexécutable.

Les tons les plus favorables au cor anglais, sont: Sol majeur; ce qui fait sur cet instrument Ré majeur; Ut majeur, ce qui fait Sol majeur; Fa majeur, ce qui fait Ut majeur; et $\mathrm{Si}$ b majeur; ce qui fait $\mathrm{Fa}$ majeur.

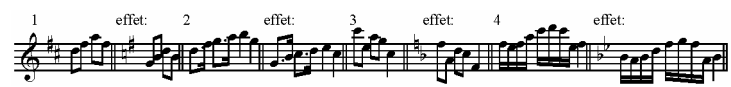

Dans aucun cas cet instrument n'est propre à des passages rapides, mais seulement à un chant simple, ou à des sons prolongés d'un caractère mélancolique; on ne s'en sert pas souvent dans l'orchestre, dans ce cas il n'y en a ordinairement qu'un seul, très rarement deux, et quand il arrive qu'on y introduit deux cors anglais, on laisse les hautbois de côté, parceque les artistes qui jouent le hautbois, jouent presque toujours aussi le cor anglais. ${ }^{115}$

Dans les fortissimos de tout l'orchestre cet instrument est difficile à entendre, car son

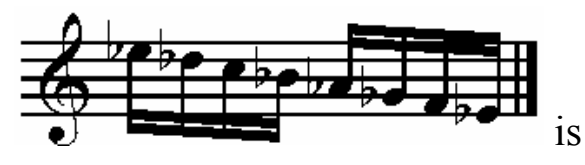

impracticable.

The keys most favorable to the English horn are: G major; which is D major on this instrument; C Major, which is $\mathrm{G}$ major; $\mathrm{F}$ major, which is $\mathrm{C}$ major; and $\mathrm{B} b$ major; which is $\mathrm{F}$ major.

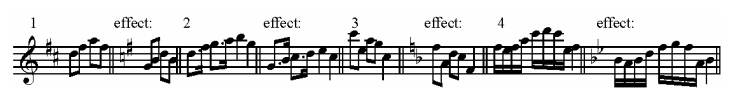

In no case is this instrument is not suitable for fast passages, but only for a simple song, or sustained tones of a melancholic character; it is not used often in the orchestra. When used in orchestra there is usually only one, very seldom two; if there does happen to be two English horns, the players keep their oboes to the side, because the artists who play the oboe almost always play the English horn as well.

In the fortissimo passages played by the full orchestra, this instrument is difficult 
timbre n'est pas aussi perçant que celui du hautbois. On ne l'emploie jamais dans la musique militaire.

\section{LE BASSON.}

On appelle cet instrument basson (du hautbois) parcequ'on le regarde comme la basse du hautbois et qu'il tire son origine de cet instrument, ainsi que nous l'avons déjà dit. Il est à l'unisson avec le violoncelle; on l'écrit sur la clef de Fa 4 . $^{\text {me }}$ ligne, et tous ses tons font le même effet que l'expriment les notes. Les notes les plus élevées s'écrivent le plus souvent sur la clef de ténor et même sur la clef de Sol. Comme on a beaucoup perfectionné le basson, son étendue est aujourd'hui:

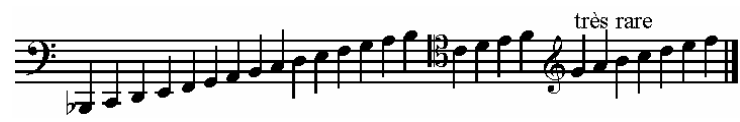
avec les tons et demi-tons son étendue peut l'orchestre n'est que:

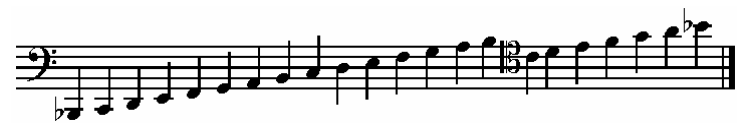

On peut donner sur le basson ordinaire l'Ut et le Si b, mais comme l'effet n'en est to hear because its timbre is not as piercing as that of the oboe. It is never used in military music.

\section{THE BASSOON}

This instrument is called the bassoon (of the oboe) because it looks it like a low oboe and it draws its origin from this instrument, as we have already said. It is played in unison with the violoncello; one writes it on the bass clef, and its written pitch is the same as its sounded pitch. The highest notes are most often written on the tenor clef or even on the treble clef. Because the bassoon has been perfected over the years, today its range is:

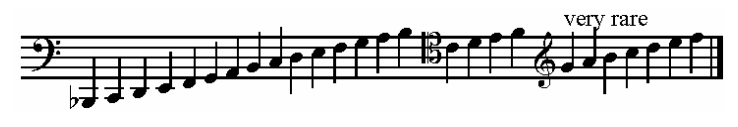

with tones and semitones, its range in orchestral works is only:

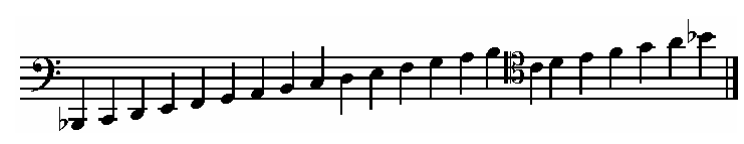

$\mathrm{C}$ and $\mathrm{B} b$ can be played on the ordinary bassoon, but as the effect is hardly 
guère agréable, il ne faut pas s'en servir

dans des passages rapides; sur les anciens

bassons on ne peut pas du tout

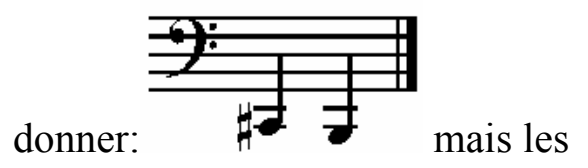

nouveaux enrichis de beaucoup de clefs

s'étant peu à peu répandus, on n'a plus

besoin d'avoir égard à ces défectuosités.

Quelques trilles sont mauvais et on ne doit

pas les employer

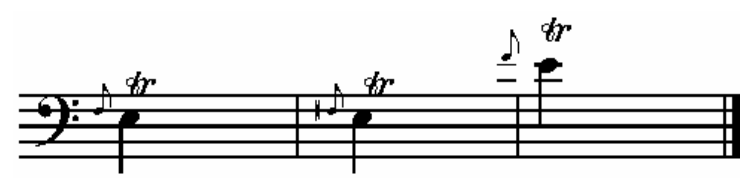

Les tons les plus faciles sont: Mib majeur,

Si b majeur; Fa majeur; Ut majeur, Sol

majeur, Ré majeur, La majeur, et leurs

tons relatifs mineurs.

Les autres étant plus difficiles, il faut

composer simplement pour cet instrument, dans ces tons.

Les sons élevés du basson sont aussi

percans que les sons élevés du violoncelle;

c’est pourquoi un seul son bien prolongé

fait plus d'effet que beaucoup de passages pleasant, one should not use it in fast

passages; on the old bassoons one cannot

produce:

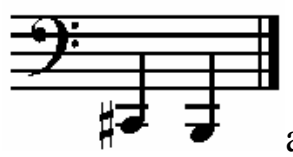

new bassoons (endowed with many clefs)

are becoming, little by little, more and

more widespread, one no longer need

worry about these defects.

Some trills are of a bad effect and should not be used, such as:

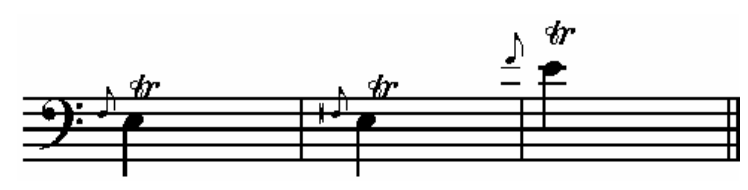

The easiest keys are: $\mathrm{E} b$ major, $\mathrm{B} b$ major; F Major; C Major, G major, D major, A major, and their relative minor keys.

As the other keys are more difficult, one must compose simply in the above keys for this instrument.

The high sounds of the bassoon are as

piercing as the high sounds of the violoncello; this is why only one sound prolonged well produces more of an 
compliqués.

Ordinairement on a un premier et un second basson; le second est naturellement écrit un peu plus bas que le premier, mais, quoique le basson soit le plus bas de tous les instrumens à vent, dans l'orchestre il n'est pas, pour cela, nécessaire qu'il fasse toujours la même partie que le violoncelle et la contrebasse.

Il faut lui donner plus de sons prolongés que de figures, et si ces sons prolongés

peuvent s'exécuter pianissimo, ils

produisent souvent le plus bel effet.

Des solos pour les deux bassons à intervalles de tierces ou autres semblables, remplissent bien leur but, surtout, s'ils sont doublés par d'autres instruments, ou si l'accompagnement de l'orchestre est très faible, car, dans les tons du médium le basson est si aisément couvert que son effet devient presque nul. Les notes piquées sont d'une exécution très facile. effect than do many complicated

passages.

Usually there is a first and a second

bassoon; the second is naturally written a little lower than the first, but, though the bassoon is lowest of all the wind instruments, in the orchestra it is not necessary for it to always play the same part as the violoncello and the double bass.

One must give it more sustained tones than figures, and if these sustained tones can be played pianissimo, they often produce the most beautiful effect.

Solos for two bassoons with intervals of thirds or other similar intervals fulfill their goal well, especially if they are doubled by other instruments, or if the accompaniment by the orchestra is very weak, because in the middle tones, the bassoon is so easily covered that its effect is nearly null. Staccato notes are very easy to execute. 
Dans la musique militaire, on ne rencontre plus le basson que très rarement, et alors, d'ordinaire, on écrit pour lui obligato; de plus, ces solos, dans les octaves supérieurs, sont habituellement doublés par d'autres instrumens, parceque, sans cette aide, le son du basson n'est perceptible qu'avec un accompagnement excessivement faible, à cause de son timbre couvert.

Nous avons des Méthodes pour le basson de Ozi, (acceptée par le conservatoire de Paris,) Froelich, Almenraeder, et autres. ${ }^{116}$

\section{LE CONTREBASSON.}

Le contrebasson est une octave plus bas que le basson ordinaire; 1'étendue dont on se sert habituellement commence au Ré de la contre octave et va jusqu'au Ré, au maximum $M i$ de la petite octave, ce qui représenté par des notes forme:

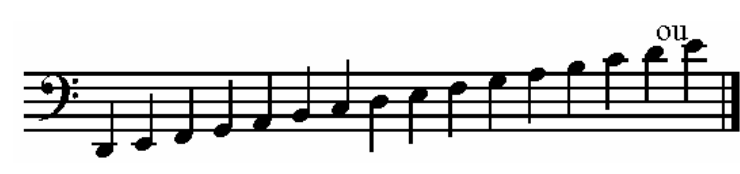

Dans cette étendue le contrebasson comprend tous les tons et demi-tons, il
In military music, there are seldom bassoons, and then, usually, one writes for it obbligato; moreover, these solos, in the higher octaves, are usually doubled by others instruments, because, without this help, the sound of the bassoon is perceptible only with an excessively weak accompaniment, because of its muffled timbre.

There are methods for the bassoon by Ozi, (accepted by the academy of Paris) Froelich, Almenraeder, and others.

\section{THE CONTRA-BASSOON}

The contra-bassoon is an octave lower than the ordinary bassoon; the range one usually uses starts with D of the contraoctave and goes to $\mathrm{D}$, with the highest being $E$ of the small octave, which is represented by these note forms:

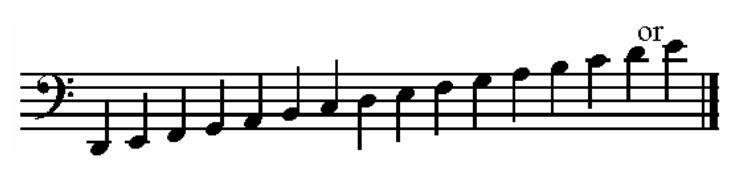

In this range, the double bassoon includes all the tones and semitones; it can even 
peut même exécuter des trilles dans les

tons simples. $^{117}$

Un passage exécuté sur cet instrument fait

l'effet suivant:

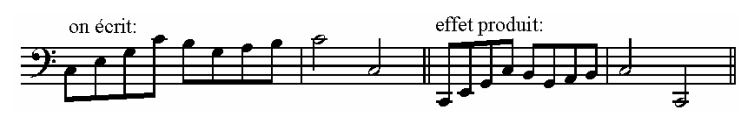

Des figures même assez rapides sont d'une

exécution facile, seulement il ne faut pas

qu'elles soient trop fréquentes dans la

basse fondamentale.

Les notes piquées se succédant rapidement

ne valent rien pour cet instrument,

parcequ'elles se confondent aisément l'une

dans l'autre à cause de la gravité du son;

mais dans un mouvement lent, on peut

s'en servir avec avantage.

Le contrebasson sert surtout, le plus

souvent, dans la musique militaire; on ne

l'a introduit que rarement dans l'orchestre.

\section{LA CLARINETTE}

A l'extérieur, la clarinette ressemble

presque au hautbois, mais son timbre est play trills in simple keys.

A passage played on this instrument

produces the following effect:

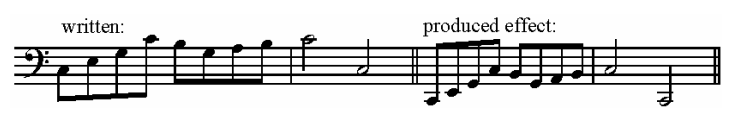

Even rather fast figures are easy to play; one must only take care that they do not occur too frequently in the fundamental bass.

Staccato notes played rapidly are not at all suitable for this instrument, because they blend too easily with one another due to the lowness of the sounds they produced, but in a slow tempo, one can use it to one's advantage.

The double bassoon is especially useful, most often, in military music; one introduced it into the orchestra only seldom.

\section{THE CLARINET}

On the outside, the clarinet closely resembles the oboe, but its timbre is 
celui qui se rapproche le plus de la voix

humaine. Elle est beaucoup plus riche en

tons que le hautbois, et la plupart des

autres instrumens à vent.

Elle a beaucoup de clefs et peut descendre

jusqu'au Mi de la petite octave et monter

jusqu'à l'Ut de la 5. ${ }^{\text {me }}$ petite octave:

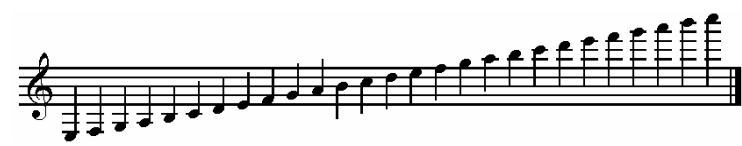

Cette dernière note et toute la $4 .^{\text {me }}$ petite octave ne doivent servir que pour des solos ou concertos.

L'étendue, qu'on emploie d'ordinaire, commence au $M i$ de la petite octave et va jusqu'au $M i$, tout au plus $F a$ de la 4 . $^{\text {me }}$ petite octave:

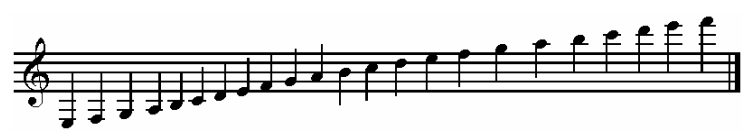

Quoique la clarinette ne puisse exécuter qu'imparfaitement certains trilles et passages tels que:

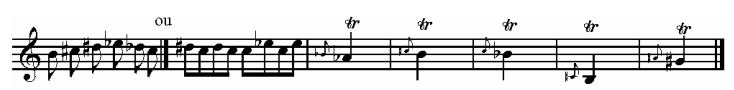

et autres, on peut néanmoins s'en servir closest to the human voice. It is much richer in tone than the oboe, and most other wind instruments.

It has many keys and can descend to E of the small octave and rise to the $\mathrm{C}$ of the fifth small octave:

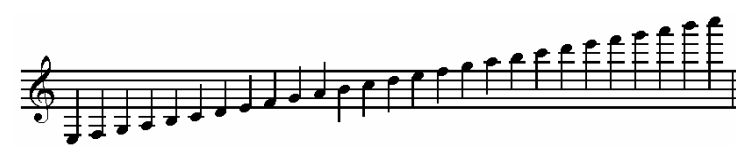

This last note and the entire fourth small octave should be useful only for solos or concertos.

The range one usually uses begins with $\mathrm{E}$ of the small octave and goes up to E or at most $\mathrm{F}$ of the fourth small octave:

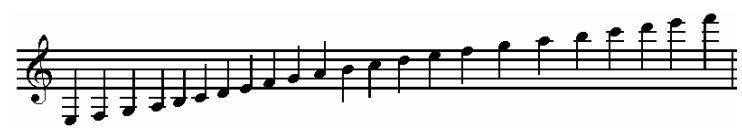

Although the clarinet can only play certain trills and passages-such

as:

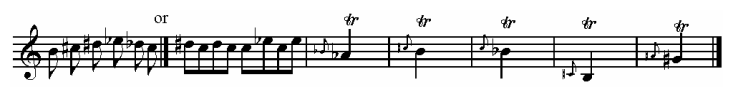

(and others) imperfectly, one can 
dans les forté où ce qu'il y a d'imparfait

dans l'exécution est couvert par la masse

de l'orchestre, ce qui ne peut avoir lieu

dans les piano ou les solos.

En général il faut éviter ces trilles autant que possible.

On fera bien de se tenir le plus souvent dans les tons du médium, parceque les tons graves, ainsi que les plus élevés, peuvent être plus convenablement rendus par d'autres instrumens.

Quant aux sons produits par le coup de langue, on peut appliquer à la clarinette ce qui a été dit pour la flûte à cette occasion.

Pour entendre les clarinettes dans leur beau et véritable ton, on devrait toujours en écrire la musique en Ut ou Fa, car elles ont avec les cors ce point de ressemblance qu'on peut très bien les accorder dans tous les tons possibles, au moyen du changement d'une clarinette plus haute ou plus basse, ou par une pièce de milieu, nevertheless use the clarinet in forte, where what is imperfect in execution is covered by the rest of the orchestral instruments, which cannot take place when it is played piano or in solos. In general it is necessary to avoid these trills as much as possible.

One will do well to confine the clarinet to the middle register, because the lower as well as the highest notes can be played more suitably by other instruments.

As for the sounds produced by tonguing, what was stated (above) about the flute can also be applied to the clarinet. To hear the clarinets in their true and beautiful tone, one should always write their music in $\mathrm{C}$ or $\mathrm{F}$, because along with the horns they can be very well tuned in all the possible keys by changing to a higher or lower clarinet, or by a medium part, without causing $\mathrm{C}$ and $\mathrm{F}$ to cease producing their original sounds; for 
sans que, pour cela, Ut et Fa cessent de représenter toujours leurs tons primitifs; par exemple: on se servirait de le clarinette en Ut, pour jouer en Ut ou en Fa, de la clarinette en Si bémol, pour jouer en Si bémol, Mi bémol ou La bémol; de la clarinette en La, pour jouer en La ou en Ré; de la clarinette en Si majeur, laquelle ne se rencontre pourtant que très rarement, pour jouer en Si majeur ou en Mi majeur; de la clarinette en Sol, qui est d'un ton plus basse que la clarinette en La, pour jouer en Sol ou en Ut.

Mais comme on ne trouve pas partout toutes ces espèces de clarinettes, on ne se sert, dans l'orchestre, que des trois suivantes: clarinette en Ut; clarinette en Si $b$; clarinette en La.

La clarinette en Ut est tout-à-fait à l'unisson avec le violon.

Les sons élevés depuis le Ré de la $4 .{ }^{\mathrm{me}}$ petite octave en montant, et même cette note, s'emploient déjà plus rarement et ne example: one would use the clarinet in $\mathrm{C}$, to play in $\mathrm{C}$ or $\mathrm{F}$, the clarinet in $\mathrm{B}$ flat, to play in B flat, E flat or A flat; the clarinet in $\mathrm{A}$, to play in $\mathrm{A}$ or in $\mathrm{D}$; the clarinet in B major, (which is, however, found only very seldom) to play in $\mathrm{B}$ major or in $\mathrm{E}$ major; the clarinet in $\mathrm{G}$, (which is of a tone lower than the clarinet in A) to play in $\mathrm{G}$ or $\mathrm{C}$.

But as one cannot find all of these types of clarinets everywhere, one only uses, in the orchestra, the three following: clarinet in $\mathrm{C}$; clarinet in $\mathrm{B} b$; clarinet in $\mathrm{A}$.

The clarinet in $\mathrm{C}$ is exact unison with the violin.

The sounds including and higher than D of the fourth small octave are used more rarely, and cannot be useful in solos or 
peuvent servir que dans les solos ou les

fortissimo, car le son en est très criard;

mais comme plusieurs genres de tons sont

d'une exécution très imparfaite sur cet

instrument, on a encore les deux autres

espèces de clarinettes: Si b ou La, sur

lesquelles le son est beaucoup plus

agréable que sur la clarinette en Ut. Il faut

surtout éviter sur cette dernière, les tons

avec beaucoup de dièzés; le ton avec

quatre bémols est aussi déjà très

difficile. $^{118}$

L'étendue de la clarinette en Si b est,

d'après les notes, la même que celle de la

clarinette en Ut, mais l'effet en est d'un

ton entier plus bas; par exemple:

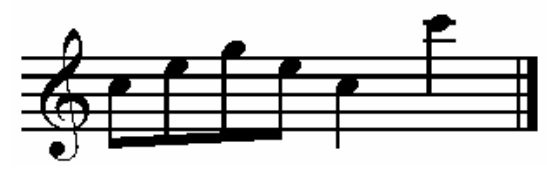

fait l'effet de:

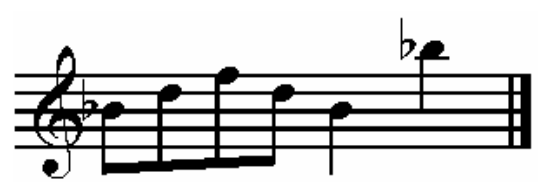

fortissimo, because the sound is very

shrill; but as several types of keys have a

very imperfect execution on this

instrument, there are two other types of

clarinets: $\mathrm{B} b$ or $\mathrm{A}$; both of these

instruments' sound is much more pleasant

than on the clarinet in C. On the latter

instrument, it is especially necessary to

avoid keys with many sharps; the key

with four flats is also quite difficult.

The written range of the clarinet in $\mathrm{B} b$ is the same as that of the clarinet in $\mathrm{C}$, but the sounding range is a whole tone lower; for example:

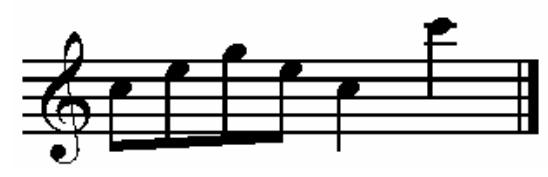

has the effect of:

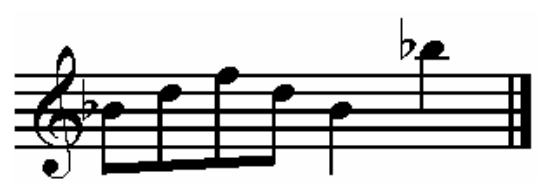


La clarinette en La a la même étendue que

la clarinette en Ut, mais l'effet est d'une

tierce mineure plus bas que celui de la

clarinette en Ut; par exemple:

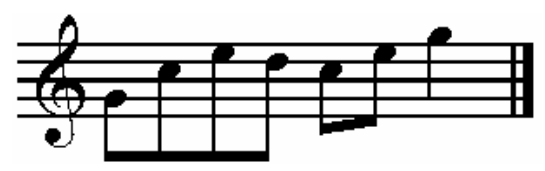

fait l'effet de:

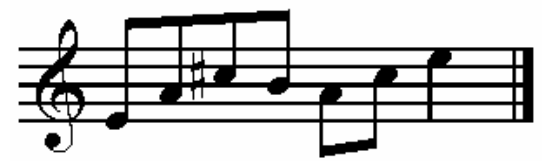

C'est pourquoi, l'on choisit, (comme nous

l'avons déjà dit précédemment,) pour les

différens tons les espèces de clarinettes

suivantes: si un morceau de musique est

écrit en $M i b$ majeur, on se sert de la

clarinette en $S i$ b qui joue alors en $F a$, ce

qu'il faut avoir soin d'indiquer dans la

partie de clarinette, comme dans la

partition; exemple:

Clarinette en Sib:

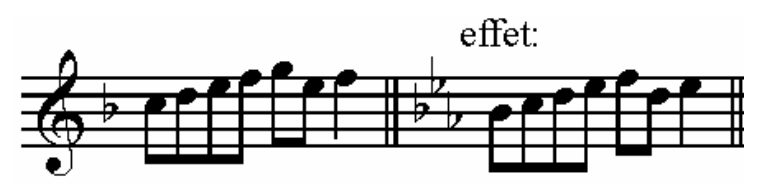

On peut encore se servir de la clarinette en

The clarinet in A has the same range as

the clarinet in $\mathrm{C}$, but sounds a minor third lower than the clarinet in $C$; for example:

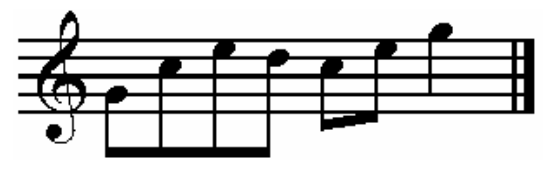

has the effect of:

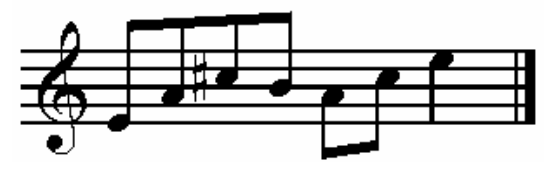

This is why one chooses (as we have already previously stated) for the different pitches, the following types of clarinets: if a piece of music is written in $\mathrm{E} b$ major, one uses the clarinet in $\mathrm{B} b$ which then plays in $\mathrm{F}$; this must be properly indicated in the clarinet part as well as in the score; for example:

\section{Clarinet in $B b$ :}

effect:

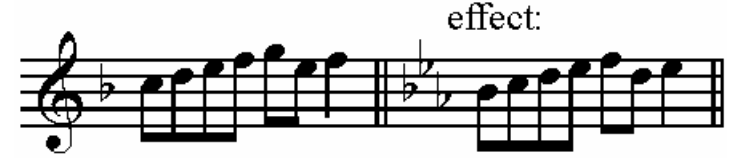

The clarinet in $\mathrm{B} b$ is still used in the 
Si b dans les tons suivans [sic]: Si b

majeur, $F a$ majeur, $M i b$ majeur, $L a b$

majeur, Réb majeur, et leurs tons relatifs

mineurs; mais pour les deux derniers

tons ${ }^{119}$ il faut composer simplement,

parcequ'ils sont déjà très difficiles;

exemple:

Clarinette in $\mathrm{Si}$ :

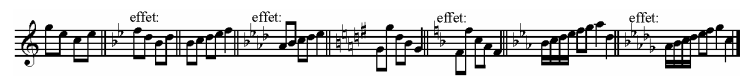

Quant le morceau de musique est en $L a$

majeur, on se sert de la clarinette en $L a$ qui

alors joue en $U t$ majeur; par exemple:

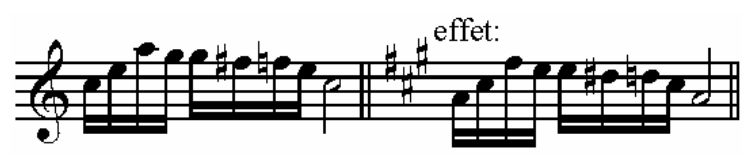

On se sert également de cette clarinette dans les tons: Ré majeur, $M i$ majeur, $S i$ majeur, $F a$ dièze majeur, et quelquefois Sol majeur; exemple:
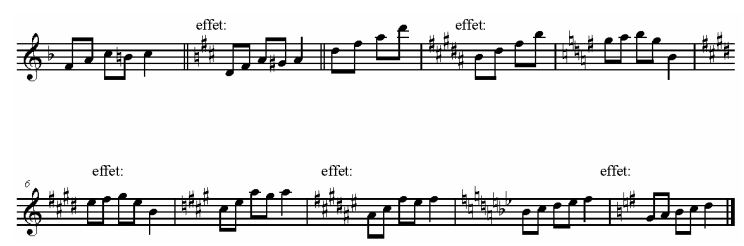

Si l'artiste se sert de la clarinette en $U t$, et qu'il doive jouer ensuite avec la clarinette following keys: $\mathrm{B} b$ major, $\mathrm{F}$ major, $\mathrm{E}$ b major, $\mathrm{A} b$ major, $\mathrm{D} b$ major, and their relative minor keys; but, for the last two keys one must compose simply, because these keys are already very difficult; for example:

Clarinet in $\mathrm{B} b$ :

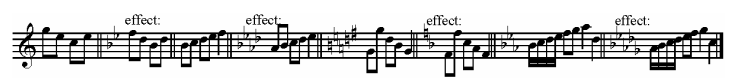

When the piece of music is in A major, one uses the clarinet in A which then plays in $\mathrm{C}$ major; for example:

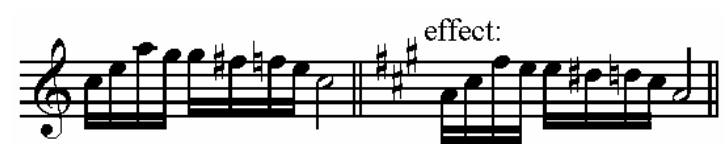

The clarinet in A is also used in the following keys: D Major, E major, B major, F sharp major, and sometimes $\mathrm{G}$ major; for example:

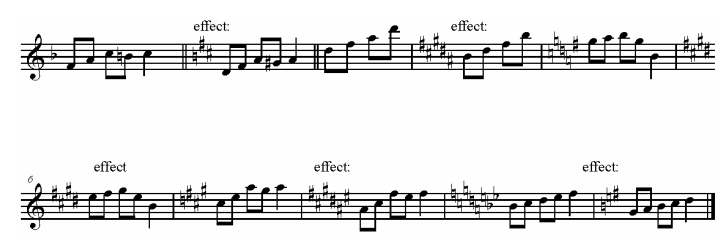

If the artist uses the clarinet in $\mathrm{C}$ and he must later use the clarinet in $\mathrm{B} b$ or $\mathrm{A}$, it 
en $S i b$ ou en $L a$, il faut au moyen des

pauses lui laisser le tems nécessaire pour

changer d'instrument, et, si cela se peut, ne

pas commencer immédiatement par un

solo, car l'instrument qui m'a pas été joué

depuis quelque tems est froid, et le ton en

a baissé, ce qui serait d'un effet choquant

dans un solo.

Il y a également dans l'orchestre une

première et une seconde clarinette qui sont

très convenables à des solos, soit pour une

seule, soit pour les deux ensemble, car le

son en est plein. Elles peuvent aussi, soit

l'une, soit les deux ensemble, servir

comme accompagnement avec des notes

tenues piano, ce qu'on peut exécuter

depuis le $M i$ le plus grave, jusqu'à l' $U t$ de

la $4 .{ }^{\text {me }}$ petite octave.

La clarinette se distingue par là du

hautbois (qui ne peut pas exécuter un

pianissimo avec des notes prolongées,) à

cause de la douceur de ses sons; on la

traite quelquefois dans la distribution des is necessary to pause and give the artist

the necessary time to change instruments,

and, if possible, to not have him start

immediately with a solo, because an

instrument which has not been played for

some time is cold and its pitch has

dropped, which would create a shocking

effect in a solo.

In the orchestra, there are also a first and

a second clarinet that are very suitable for solos, either for one alone, or for both as

a unit, because they produce a very full

sound. In addition, either one of the

clarinets, or both of them together, can

serve as an accompaniment to notes that

are sustained piano, which can be played

from the lowest $\mathrm{E}$ to $\mathrm{C}$ of the fourth small

octave.

The clarinet is distinguished from the

oboe (which cannot play a pianissimo in

prolonged notes) by the softness of its

sounds; sometimes, through the

distribution of its intervals, it is treated 
intervalles, comme l'alto, mais il arrive

aussi souvent que la première clarinette

renforce la mélodie.

En composant pour la clarinette en $L a$ ou

celle en $\mathrm{Si}$, il faut prendre garde de bien

transposer dans l'autre ton les dièzés ou les

bémols accidentels; car souvent un dièze

se change en double-dièzé, ou un bémol se

change en bécarre $\&^{\mathrm{a}}$ par exemple:

Clarinette en Si b

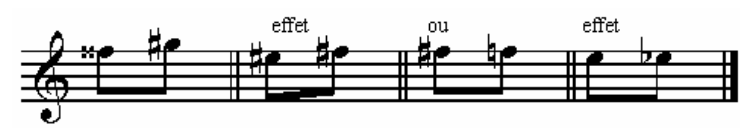

Clarinette in La

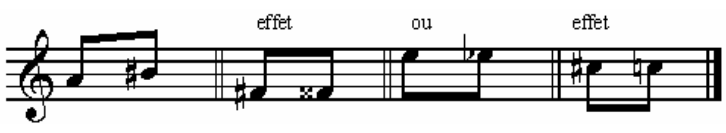

Dans la musique militaire on emploie aussi

une première et seconde, quelquefois

même une troisième et quatrième

clarinette, mais chacune de ces parties est

exécutée par plusieurs artistes à la fois, de

sorte que, dans les morceaux de longue

haleine, on n'a plus besoin d'avoir égard à

la fatigue des artistes, car ils peuvent se

relayer; quelquefois on est même forcé like the viola, but just as often, the first

clarinet will reinforce the melody.

While composing for the clarinet in A or in $\mathrm{B} b$, one must be careful to transpose the coincidental sharps or flats well into the other key, for often a sharp changes into double-sharp, or a flat changes into a natural sign and the like, for example:

\section{Clarinet in $B$ b}

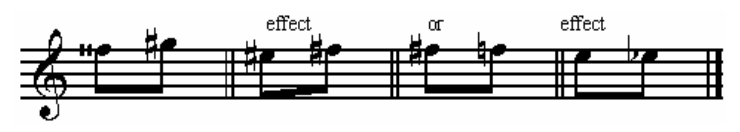

Clarinet in $A$

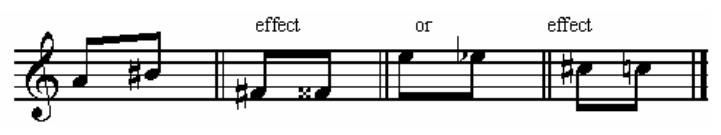

In military music, a first and second are also used, sometimes even a third and fourth clarinet, but each one of these parts is played by several artists at the same time, so that, in pieces requiring long breaths, one need not concern oneself about the artists' fatigue, because they can take turns. In military music, sometimes one is even forced to write 
d'écrire des passages un peu longs pour la clarinette, dans la musique militaire, parcequ'elle y forme la partie principale.

Le genre de clarinette dont on se sert habituellement dans la musique militaire Française est la clarinette en $S i b$, cependant, on rencontre en Allemagne des musiques qui emploient la clarinette en $U t$, celle en $L a$ n'est usitée que très rarement.

Clarinettes en Mi b, Fa, et Ré.

Outre les clarinettes que nous avons décrites ci-dessus, il en existe encore trois espèces plus hautes, l'une en $M i b$, la seconde en $F a$, et la troisième, mais qui est plus rare, en Ré.

L'étendue de la petite clarinette en $M i b$ commence au Sol de la petite octave et va jusqu'au $F a$, tout au plus $S o l$ de la 4 me petite octave, mais, comme elle est d'une tierce mineure plus élevée que la clarinette en $U t$, l'étendue représentée par les notes est:

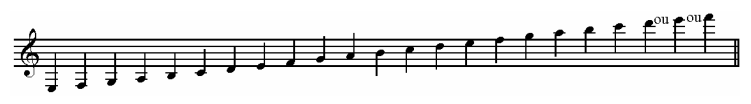

somewhat long passages for the clarinet, because it forms the principal part in that genre.

The kind of clarinet which is usually used in French military music is the clarinet in $\mathrm{B} b$, however, in Germany the clarinet in $\mathrm{C}$ is sometimes used, that in $\mathrm{A}$ is used only very seldom.

Clarinets in $\mathrm{E} b, \mathrm{~F}$, and D.

In addition to the clarinets which we have discussed above, there are three higher types, first, one in $\mathrm{E} b$, the second in $\mathrm{F}$, and the third, which is rarer, in D.

The range of the small clarinet in $\mathrm{E} b$ starts on $\mathrm{G}$ of the small octave and goes to $F$, or at most $G$ of the fourth small octave, but, as it is a minor third higher than the clarinet in $C$, the range represented by the notes is:

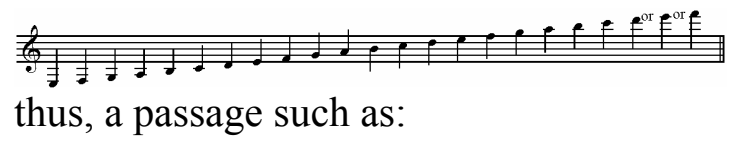


ainsi, un passage tel que:

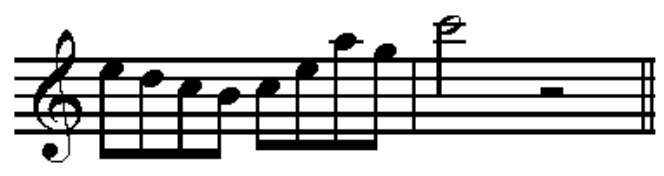

fait l'effet de:

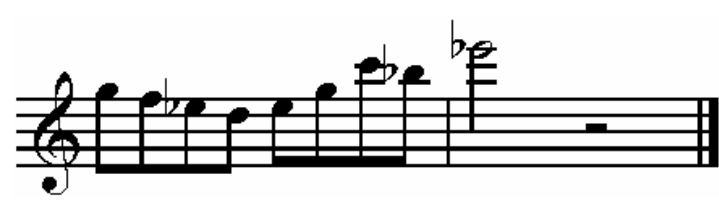

Viola pourquoi les tons les plus propres à cet instrument sont les suivans: $L a b$ majeur, où il joue $F a$ majeur; $M i$ b majeur, où il joue $U t$ majeur; Sib majeur, où il joue Sol majeur, Réb majeur, où il joue $S i b$ majeur, et $F a$ majeur, où il joue Ré majeur, ce qui montre qu'on ne doit s'en servir que lorsque les grandes clarinettes sont en $S i b$, parceque, dans ces deux espèces, les tons s'accordent le mieux.

La petite clarinette en $F a$ est d'une quarte plus haute que la clarinette en $U t$, ou bien d'un ton entier plus haute que la clarinette en $M i b$.

L'étendue de la clarinette en $F a$ commence donc au $L a$ de la petite octave,

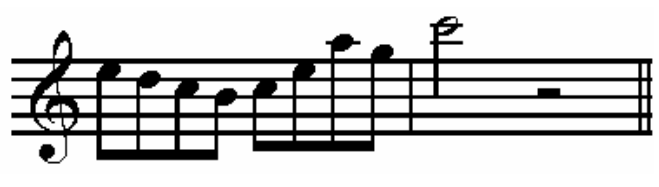

produces the following effect:

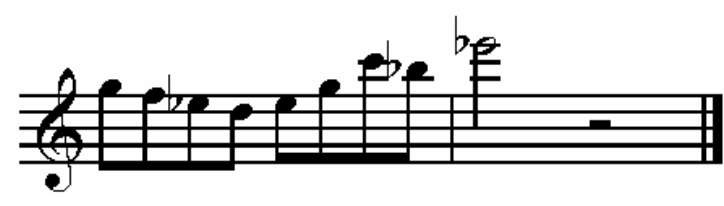

This is why the keys that are best for this instrument are: $\mathrm{A} b$ major, which plays $\mathrm{F}$ major; $\mathrm{E} b$ major, which plays $\mathrm{C}$ major; $\mathrm{B} b$ major, which plays $\mathrm{G}$ major; $\mathrm{D} b$ major, which plays $\mathrm{B} b$ major; and $\mathrm{F}$ major, which plays D major, which shows that it should only be used when the large clarinets are in $\mathrm{B} b$, because the keys are tuned the best with these two types.

The small clarinet in $\mathrm{F}$ is a fourth higher than the clarinet in $\mathrm{C}$, or a step higher than the clarinet in $\mathrm{E} b$.

The range of the clarinet in $\mathrm{F}$ begins with the A of the small octave, and goes to $G$ 
et va jusqu'au $S o l$, tout au plus $L a$ de la

4me petite octave; elle est représentée en

notes comme suit:

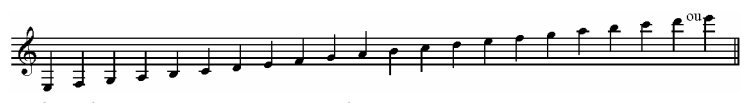

ainsi, un passage tel que:

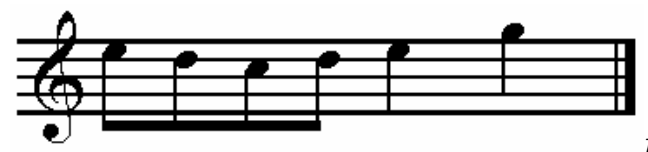

fait

l'effet

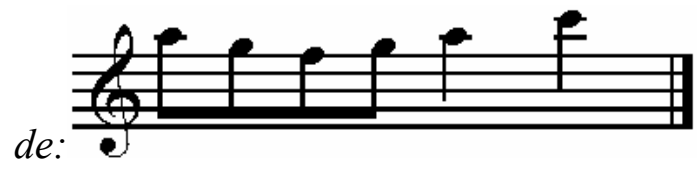

Les tons les plus favorables à la clarinette

en $F a$, sont: $S i b$ majeur, où elle joue $F a$

majeur; $F a$ majeur, où elle joue $U t$ majeur;

$U t$ majeur, où elle joue Sol majeur; Sol

majeur, où elle joue Ré majeur; et $M i b$

majeur, où elle joue $S i$ b majeur; ce qui

montre que l'on doit employer la petite

clarinette en $F a$, lorsqu' on se sert en même

tems des clarinettes en $U t$.

La petite clarinette en Ré n'est que d'un

ton plus élevée que la clarinette ordinaire

en $U t$; elle a l'étendue suivante:

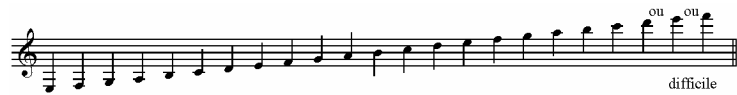

or A of the fourth small octave; it is

written as follows:

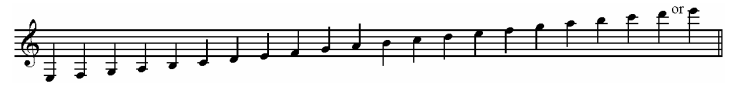

thus, a passage such as:

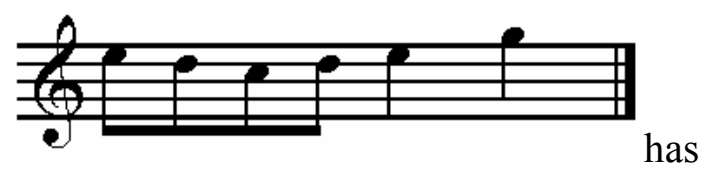

the effect of:

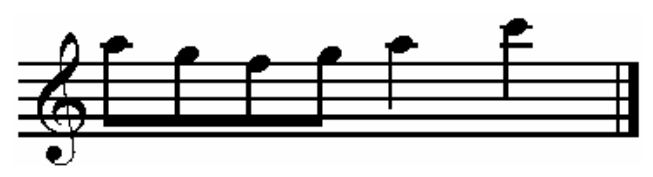

The keys most favorable to the clarinet in $\mathrm{F}$ are: $\mathrm{B} b$ major, which plays as $\mathrm{F}$ major;

F major, which plays as $\mathrm{C}$; $\mathrm{C}$ major, which plays in $\mathrm{G}$ major; $\mathrm{G}$ major, which plays in $\mathrm{D}$; and $\mathrm{E} b$ major, which plays in $\mathrm{B} b$; this demonstrates that the small clarinet in $\mathrm{F}$ is used when one uses the clarinet in $\mathrm{C}$ at the same time.

The small clarinet in D is only one tone higher than the ordinary clarinet in $\mathrm{C}$; it has the following range:

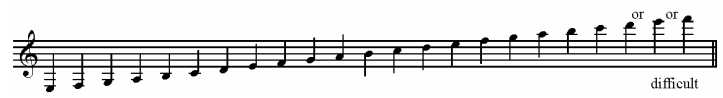


l'effet produit est:

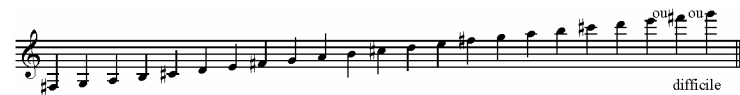

On l'emploie avec les grandes clarinettes

en $L a$. Cependant, la petite clarinette en

Ré ne se rencontre que rarement, parceque, dans les musiques militaires, les clarinettes sont ordinairement en $\mathrm{Sib}$ ou en $U t$ dans lequel cas on se sert des petites clarinettes en $M i b$ et en $F a$.

Il faut employer le plus souvent les sons du médium de ces clarinettes, et le plus rarement possible les notes graves qui peuvent être mieux rendues par les grandes clarinettes; souvent; elles marchent avec la grande clarinette, ou bien avec d'autres instrumens, à l'octave supérieure; mais, comme on emploie aussi quelquefois deux petites clarinettes, elles ont alors, ordinairement, leur marche particulière; très souvent aussi on l'écrit concertante avec la petite flûte. Tout ce qui a été dit des trilles, du coup de langue et des passages inexécutables à l'occasion de la the produced effect is:

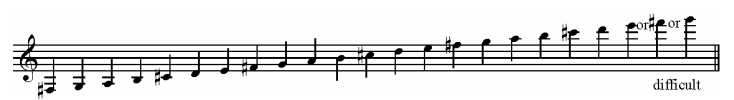

It is used with the large clarinets in A.

However, the small clarinet in D is rarely

used, because the clarinets that are used in military music are usually in $\mathrm{B} b$ or $\mathrm{C}$, in which case the small clarinets in $\mathrm{E} b$ or F would be used.

One must usually use the middle notes of these small clarinets; the lower notes should be used as little as possible, since they can be played better by the large clarinets. Often, the small clarinets play with the large clarinet or with other instruments in the higher octave; but, since one may also use two small clarinets at the same time, they can usually retain their distinctive style. One may also have the piccolo and the clarinet play together. Everything stated heretofore about trills, tonguing, and passages that are impracticable for the 
grande clarinette, se rapporte ici; il faut donc composer pour ces clarinettes avec tout autant de soin que pour les autres. Nous avons des Méthodes pour la clarinette de BACKOFEN, BERR, BLASIUS, FROELICH, De DOIGTÉ, HERNESTAEDT, LEFEVRE, Ivan MULLER $^{120}$ (inventeur de la clarinette alto et d'une clarinette a treize clefs,) Michel VANDERHAGEN, Frédéric WOLDEMAR et autres.

LE COR DE BASSETTE (ou clarinette sourdine)

Cet instrument très utile et très étendu diffère de la clarinette en ce qu'il est courbé; (et, pour cette raison on l'appelait autrefois cor courbé.) Il est d'une quinte plus bas que la clarinette en $U t$, ce qui fait qu'on l'appelle ordinairement cor de bassette en $F a$. On l'écrit sur la clef de Sol, 2 me ligne, et l'effet des notes est d'une quinte plus bas qu'elles ne sont écrites. Son étendue commence au $F a$ de large clarinet, applies here as well; it is thus necessary to compose for these clarinets as carefully as for the others. There are methods for clarinet by BACKOFEN, BERR, BLASIUS, FROELICH, De DOIGTÉ, HERNESTAEDT, LEFEVRE, Ivan MULLER (inventor of the alto clarinet and the thirteen-keyed clarinet) Michel VANDERHAGEN, Frédéric WOLDEMAR, and others. BASSET HORN (or muted clarinet)

This very useful and very extensive instrument differs from the clarinet in that it is curved (and, for this reason it was formerly called the cor courbé, or curved horn). It is a fifth lower than the clarinet in $\mathrm{C}$, which explains why it is usually called the basset horn in F. It is written on the treble clef, second line, and the notes produced sound a fifth lower than their written notes. Its range begins at $\mathrm{F}$ 
la grande octave, et va jusqu'au Sol de la

3me petite octave;

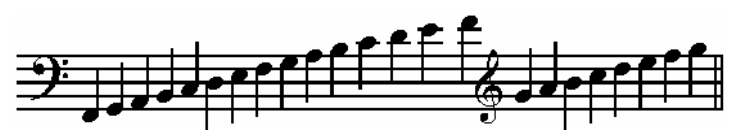

par les notes comme suit:

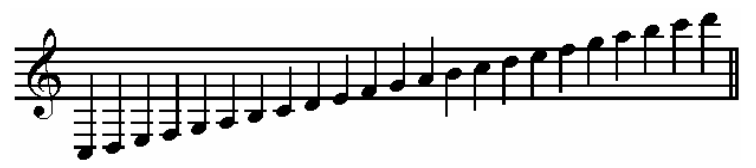

désignées une quinte plus haut que n'en est

le véritable ton. Le son de cet instrument

est doux, plein, a de la rondeur, et est

particulièrement propre à des passages

tendres ou de sentiment. On peut aussi

s'en servir pour des solos, et il y a des

artistes qui jouent sur le cor de bassette des

concertos et des variations.

La suite des tons au grave du cor de bassette ordinaire est: Ut, Ré, Mi, Fa, Fa\#; dont l'effet est: Fa, Sol, La, Si b, Si.

Exemple:

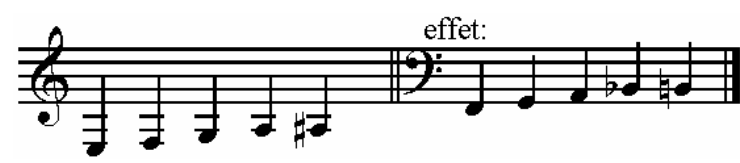

Et à partir de là tons les autres tons et demi-tons.

Les notes basses $U t \#$ et $M i b$ of the large octave, and goes to $\mathrm{G}$ of the

third small octave;

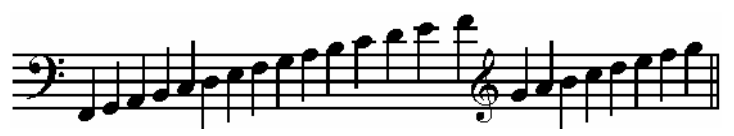

by the following notes:

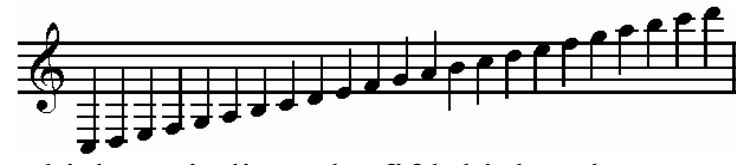

which are indicated a fifth higher than

what the true key. The sound of this

instrument is soft, full, round, and is

particularly suitable for passages that are

tender or full of sentiment. It can be used

in solos, and there are artists that use the

basset horn for concertos or variations.

The series of keys to the ordinary basset

horn's lowest key is: C, D, E, F, F\#,

which have the effect of: F, G, A, B b, B.

For example:

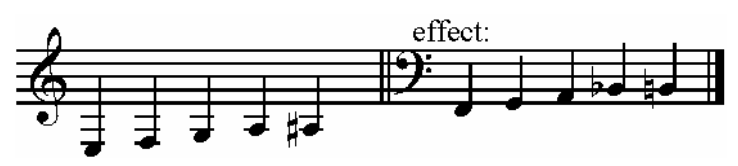

And from there follow the other tones and semitones.

The low notes $\mathrm{C} \#$ and $\mathrm{E} b$ 


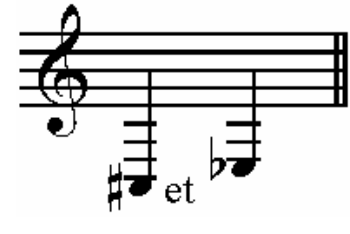

qui font l'effet

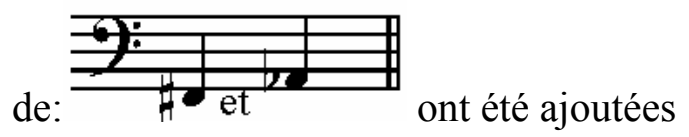

par les frères Anton STAEDLER; au

moyen de ces notes on peut maintenant

produire tous les tons d'une manière nette,

mais il vaut mieux ne pas s'en servir

parcequ'on ne trouve pas partout cet

intrument $[$ sic $]$ ainsi perfectionné. ${ }^{121}$

En général, les tons graves ne peuvent

s'employer que dans des passages et des

transitions d'une progression fort lente,

parcequ'ils sont difficiles à intonner; les

tons les plus hauts ne peuvent aussi

s'employer qu'avec précaution, mais dans

l'étendue de:

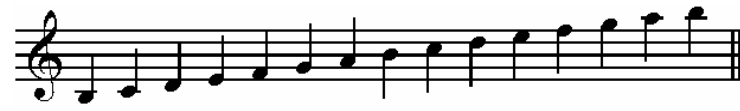

qui fait l'effet de:

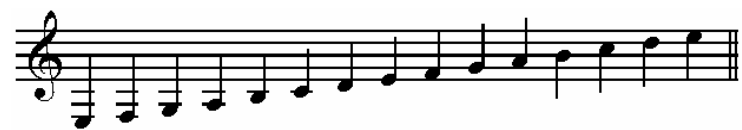

tout ce qui peut s'exécuter sur la clarinette

peut l'être également sur le cor de bassette.

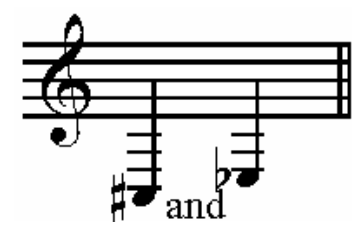

which have the effect

of:

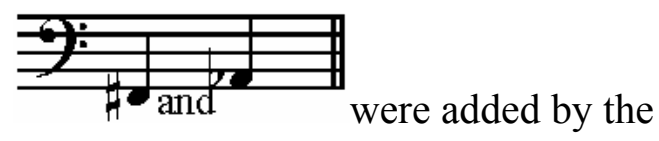

brothers Anton Staedler; with these notes

one can clearly produce all of the keys,

but it is preferable to not use these notes,

as the perfected instrument is not widely

available.

In general, the low tones are only used in

passages and in transitions of a very slow

tempo, because they are difficult to tune;

the highest tones should only be used

with caution, in the range of:

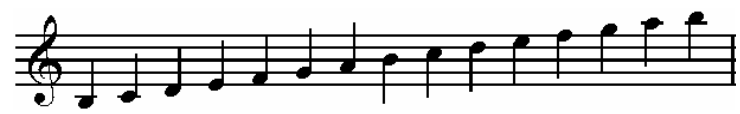

which has the effect of:

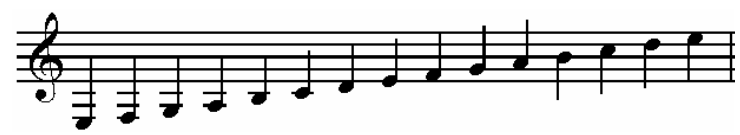

All that can be played on the clarinet can

be played on the basset horn as well. As

previously stated, a simple song, or

sustained notes are more easily executed 
Comme nous l'avons déjà dit, un chant simple, ou des notes prolongées sont d'une exécution plus facile que des roulades et passages rapides, à cause de son timbre doux et moelleux.

Dans l'orchestre, on ne se sert de cet instrument que dans des occasions extraordinaires, seul, ou quelquefois par un premier et un second, très rarement par un troisième.

Il faut encore observer que dans les passages bas, le second et troisième cor de bassette s'écrivent souvent sur la clef de Fa, 4me ligne; ainsi, au lieu de:

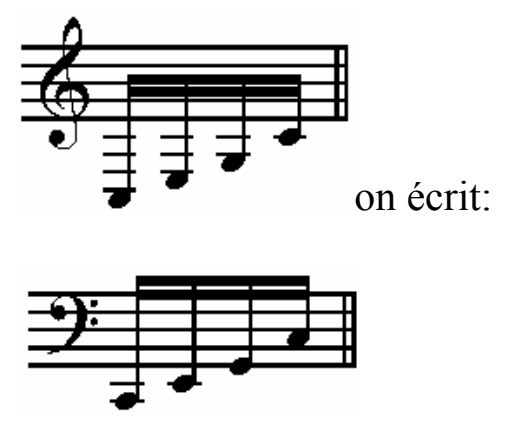

On transpose aussi souvent une octave plus haut, les passages bas écrits sur la clef de Sol, 2me ligne, afin d'éviter toutes les petites barres, et alors, on écrit au dessus le than the roulades and fast passages, because of its soft, smooth sound.

In the orchestra, this instrument is used only on very rare occasions, or sometimes with a first and second, but very rarely with a third.

One must also observe that in low passages, the second and third basset horns are written in the bass clef; so

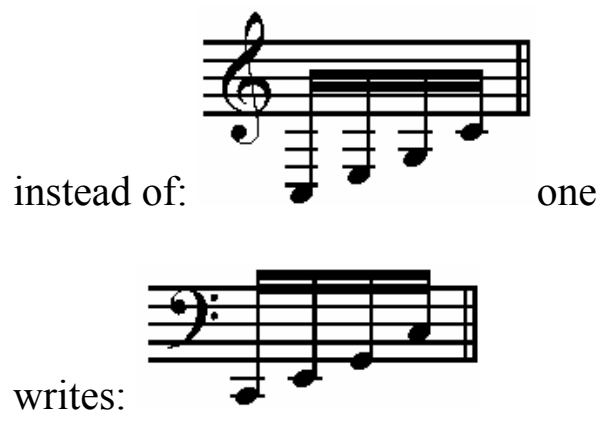

To avoid writing ledger lines, one often transposes the low passages written on the treble clef an octave higher; then one writes the word chalumeau on top, as for 
mot chalumeau comme pour la clarinette; the clarinet; so instead of:

ainsi,

au lieu de:
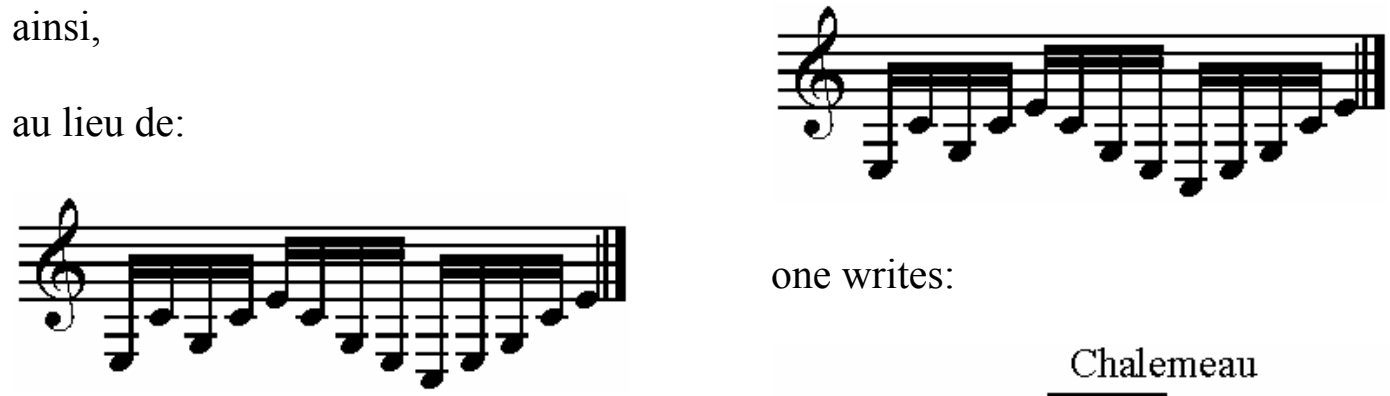

one writes:

on écrit:

Chalemeau

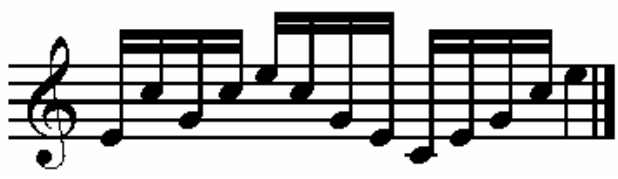

Le cor de bassette n'étant proprement

As the basset horn is only a large clarinet,

qu'une clarinette agrandie, des passages,

comme le suivant:

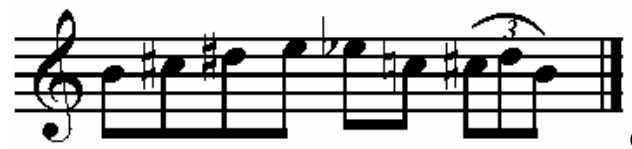

offren the same difficulties as on the clarinet.

t les mêmes difficultés que sur la

clarinette.

En général, il faut se borner aux tons les

In general, one must limit oneself to the

plus favorables qui sont: Mib majeur, où il

most suitable keys, which are: $\mathrm{E} b$ major, joue $S i b$ majeur; $S i b$ majeur, où il joue $F a$ when the basset horn plays in $\mathrm{B} b$ major;

majeur; $F a$ majeur, où il joue $U t$ majeur;

$\mathrm{B} b$ major, when it plays in $\mathrm{F}$ major; $\mathrm{F}$

$U t$ majeur, où il joue $\mathrm{Sol}$ majeur; et $\mathrm{Sol}$

major, when it plays in $\mathrm{C}$ major; $\mathrm{C}$ major,

majeur, où il joue Ré majeur:

when it plays in G major; and G major

Exemple:

when it plays in $\mathrm{D}$ major: 


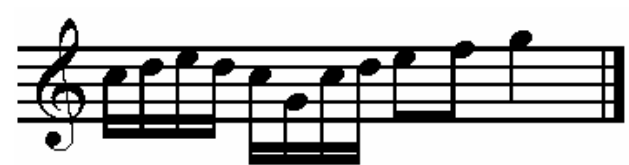

l'effet de:

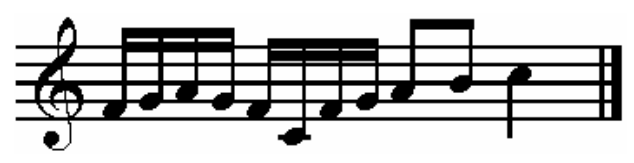

On peut aussi jouer du cor de bassette, dans des tons plus difficiles, en ayant soin de ne pas trop multiplier les figures, et en le soutenant par des parties qui remplissent le médium.

Il marche alors, ordinairement, entre la clarinette et le basson; nous ajouterons pour plus de clarté que le cor de bassette, (ainsi que la clarinette alto), est juste une octave plus bas que la petite clarinette en $\mathrm{Fa}$.

Nous avons des Méthodes pour cet instrument de: Vanderhagen, Baekofen, et Ivan Muller (qui a fait une gamme pour clarinette alto et cor de bassette.) ${ }^{122}$ LE CHALUMEAU. Cet instrument déjà très ancien a depuis
For example:

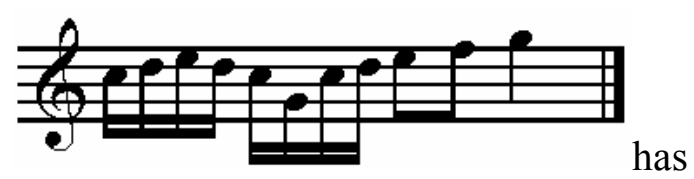

the effect of:

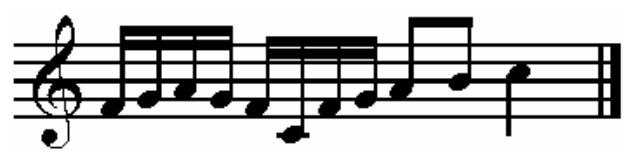

The basset horn can play in more difficult keys, if there are not too many multiple figures, and by supporting it with parts that fill out the middle.

It goes then, usually, between the clarinet and the bassoon; in order to clarify that basset horn (as well as the alto clarinet), is an octave lower than the small clarinet in $\mathrm{F}$.

There are methods for this instrument by: Vanderhagen, Baekofen, and Ivan Muller (who devised a scale for the alto clarinet and the basset horn). THE CHALUMEAU This already very ancient instrument 
long-tems disparu de l'orchestre, et on ne le trouve plus que dans les campagnes, et chez lés bergers du Tyrol.

Il se composait d'un roseau creux avec six trous et une clef, et son cornet était recourbé à peu près comme celui de notre hautbois; on le jouait aussi au moyen d'une anche semblable, mais qui aboutissait encore à une capsule particulière forcé par le haut.

On peut regarder cet instrument comme précurseur du hautbois et de la clarinette, mais on doit plutôt le considérer comme clarinette basse, car le ton en est beaucoup plus bas que celui de notre clarinette actuelle. Voilà pourquoi le nom de chalumeau est souvent employé pour la clarinette et le cor de bassette dans des passages qui doivent être joués une octave plus bas. Aussi, y a-t-il quelque ressemblance entre la forme de la clarinette et celle du chalumeau. disappeared from the orchestra a long time ago, and one finds it only in the country, and at the homes of Tyrolean shepherds.

It was composed of a hollow reed with six holes and a key, and its horn was bent approximately like that of our oboe; one also played it with a similar reed, but which ended in a special cap forced on top.

It is possible to regard this instrument as a precursor of the oboe and the clarinet, but one should instead consider it as low clarinet, because the tone is much lower than that of our current clarinet. For this reason the name of chalumeau is often used for the clarinet and the basset horn in passages that must be played an octave lower. Also, there is some resemblance between the shape of the clarinet and that of the chalumeau. 


\section{LE COR DES CAVHES, ou COR DES}

ALPES.

Cet instrument est très commun en

Allemagne et en Suisse parmi les bergers

montagnards; ils s'en servent pour charmer

leurs loisirs et aussi quelquefois pour

correspondre entre eux, s'appeler d'une

montagne à l'autre et rassembler leurs

troupeaux.

Le cor des Alpes consiste en un tuyau long

d'environ trois ou quatre pieds; le col

supérieur a près d'un pouce de diamètre,

puis l'instrument s'élargit insensiblement

en allant vers l'autre extrêmité [sic] et se

termine en pavillon comme la clarinette;

ce tube est ordinairement fait d'écorce

d'arbre; on lui adapte une embouchure en

métal ou en corne assez semblable à celle

du trombonne.

Le cor des Alpes ne peut guère donner que cinq tons pris dans deux octaves; par

exemple: Ut, Sol, Ut, Mi, Sol

\section{THE ALP HORN}

This instrument is very common in

Germany and Switzerland among the

mountain shepherds; they use it as

leisure-time activity, and also sometimes

to correspond between them, to be called

from one mountain to another and to

gather their herds.

The Alp horn consists of a long pipe

approximately three or four feet long; the

top of the neck is nearly an inch in

diameter, then the instrument widens

imperceptibly as it descends to the other

end and finishes in a width like the

clarinet; this tube is usually made of tree

bark; one attaches a mouthpiece to it,

made out of metal or animal horn, rather

similar to that of the trombone.

The Alp horn can barely play five notes

across two octaves; for example: C, G, C,

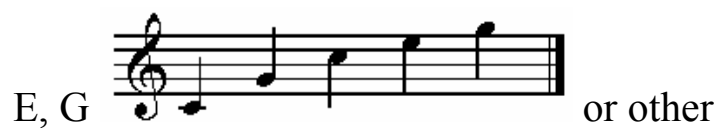




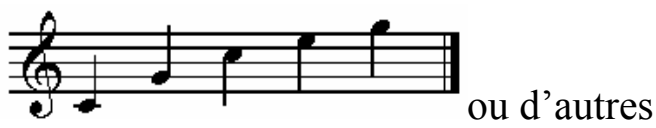

tons en partant d'unc autre tonique; les

notes plus élevées ne pourraient s'obtenir

qu'avec beaucoup de difficulté; mais les

bergers savent tirer un si bon parti de ces

cinq notes qu'ils en forment des mélodies

d'un rythme fort original, que relève

encore le timbre tout particulier de

l'instrument; par exemple: cette mélodie la

plus répandue est peut-être la mère de

toutes les autres; c'est celle qui a dû servir

de thème aux nombreuses vart. ${ }^{\text {ons }}$ qu'on en

a données.

L'accord du cor des Alpes dépend

naturellement de la grandeur de

l'instrument.

J'ai parlé de cet instrument parcequ'il est parfois d'un bon effet au théâtre, on l'a même imité dans plusieurs Opéra il est donc essentiel de connaître les dispositions de ses cinq tons et le genre de mélodie auquel on les approprie. tones based on another tonic; the higher notes are difficult to play; but the shepherds are so deft in using these five notes that they form melodies of an extremely original rhythm, which raises this instrument's distinctive timbre even more; for example:

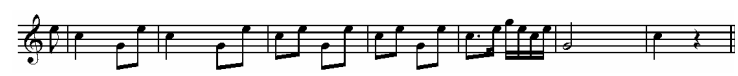

This is the most widespread melody, and is perhaps the origin of all the others; it must have been used as a theme of which many variations have been written.

Naturally, the tuning of the Alp horn depends on the size of the instrument.

I have spoken about this instrument because it sometimes creates a good effect in the theatre; it has even been imitated in several operas, it is thus essential to know the arrangements of its five tones and the kind of melody that can 
be adapted to it.

\section{LE SERPENT.}

Le serpent ainsi nommé à cause de sa

forme sinueuse est principalement

employé dans la musique militaire.

Son étendue, d'après les notes, est:

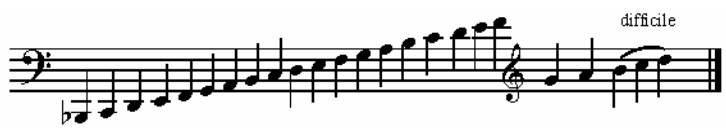

\section{THE SERPENT}

The serpent, thus named because of its

sinuous form, is used mainly in military

music.

Its range, as written, is:

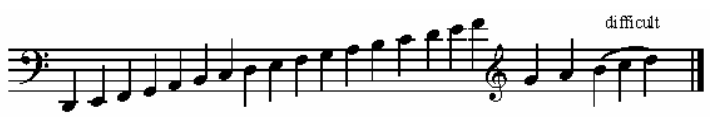

Cependant, l'étendue qui sert

habituellement, est, comme pour le contre-

basson depuis le Ré de la grande octave,

jusqu'au Ré, Mi ou Fa de la 2. ${ }^{\text {me }}$ petite

octave:

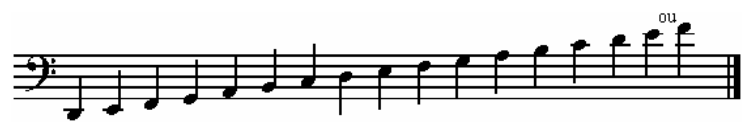

Ces tons résonnent très fortement et par

leur nature appartiennent en propre à

l'instrument, tandis que les tons plus

élevés ressemblent à ceux du basson; du

reste, ce qui a été dit du contrebasson se

rapporte aussi au serpent.

Le serpent est un instrument très ingrat à

cause de son embouchure et il exige un
However, the range which is usually

used, is like that of the double bassoon:

from $\mathrm{D}$ of the great octave, to $\mathrm{D}, \mathrm{E}$ or $\mathrm{F}$

of the second small octave:

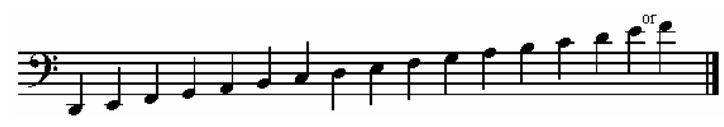

These tones resonate very strongly and by

their nature, belong exclusively to this

instrument, while the higher tones

resemble those of the bassoon; as for the

rest, what was stated about the double

bassoon also refers to the serpent.

The serpent is a very trying instrument

because of its embouchure. It requires an 
artiste qui ait beaucoup d'oreille, car on

peut donner, a volonté, chaque note un

quart de ton plus haut ou plus bas.

Nous avons des Méthodes pour le serpent

de Froelich, Hardi, Sens, Metoyen, Roze,

Trighot (qui a fait imprimer une gamme

pour cet instrument), et autres. ${ }^{123}$

\section{LE COR}

Le cor qui est presque toujours employé

double, savoir: corno primo, corno

secondo, est un instrument très connu

rond, en cuivre jaune (plus rarement en

argent); on le joue avec une embouchure

de la même matière. ${ }^{124}$

Le cor s'écrit sur la clef de Sol 2. ${ }^{\text {me }}$ ligne;

cependant, les sons graves, ils se

prolongent pendant plusieurs mesures,

s'écrivent quelquefois, pour le second cor,

sur la clef de $F a, 4{ }^{\text {me }}$ ligne.

Les sons qu'il peut donner naturellement

sont les suivans:

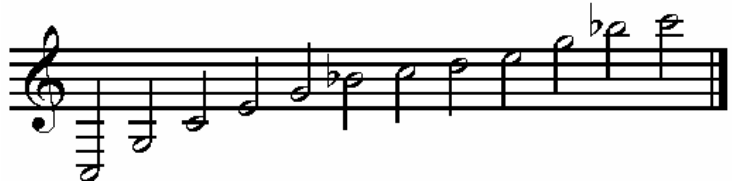

artist who has a good ear; because one can play each note a quarter tone higher or lower, as desired.

There are methods for the serpent by

Froelich, Hardi, Sens, Metoyen, Roze,

Trighot (who printed a range for this

instrument), and others.

\section{THE HORN}

The horn, which is almost always used in

pairs called first horn and second horn, is

a very round instrument, made out of

brass (more rarely out of silver); that is

played with an embouchure made of the

same material.

The horn is written on the treble clef;

however, sometimes the low sounds for

the second horn that are prolonged for

several measures are written on the bass

clef.

The sounds that the horn can play

naturally are the following:

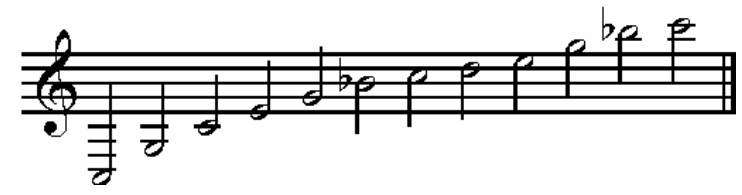


On les appelle, pour cette raison, tons naturels.

Les tons et demi-tons qu'on produit en introduisant la main dans le pavillon, ne doivent s'employer qu'avec précaution, et s'appellent tons bouchés.

Pour chaque ton, on a besoin d'un nouvel accord qui s'obtient au moyen d'un corps de rechange, car les cors jouent presque toujours en $U t$ majeur.

Il faut que le compositeur ait soin d'indiquer l'accord, dans la partition et dans la partie séparée; le plus bas de ces accords est $S i b$, que l'on indique: cor en Si b grave. On ajoute le mot grave, parcequ'il y a encore un autre accord en Sib.

Cet accord est, une octave et un ton entier plus bas que le violon ou la clarinette en $U t$, et pour cette raison, juste d'une octave plus bas que la clarinette en $\mathrm{Si}$. Avec ce cor, aussi bien qu'avec tous les autres, pour l'orchestre et la musique
For this reason, they are called natural tones.

The tones and semitones which are produced by placing the hand into the bell used judiciously; they are called muted tones.

Because the horns almost always play in C major, each key needs to be newly tuned, which is performed using a crook.

The composer must take care to indicate the chord in the score and the individual part; the lowest of these chords is $\mathrm{B} b$, which is indicated as: "horn in low B b". The word "low" is added because there is also another chord in $\mathrm{B} b$.

This chord is an octave and a whole tone lower than the violin or the clarinet in $\mathrm{C}$; for this reason, it is just an octave lower than the clarinet in $\mathrm{B} b$. With this horn as well as with all the others for orchestra and military music, 
militaire, on ne peut donner avec effet que certains sons de l'accord dont on se sert, et encore quelques notes étrangères à cet accord.

Comme le cor, ainsi que nous l'avons dit, s'emploie dans l'orchestre et dans la musique militaire, par un premier et un second, il faut observer que le premier ne doit jamais descendre aussi bas que le second, ni le second monter aussi haut que le premier.

On trouvera ci-dessous des exemples qui montreront quelles sont les notes qui font le meilleur effet pour les différens accords; et, a côte, l'effet de ces notes jouées sur le cor, soit premier, soit second. Ainsi pour l'accord $S i b$ grave, on peut écrire:

Cor $1^{\text {er }}$ en Si grave:

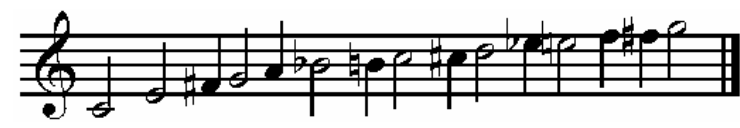

effet: one can only play to good effect certain specific sounds in the chord one is using at the time, and a few notes outside this chord.

Since the horn, as previously stated, is used in the orchestra and in military music with a first and a second, it should be observed that the first horn should never go as low as the second, nor the second as high as the first.

One will find below examples that will demonstrate which notes make the best effect for the different chords, as well as the effect of these notes played on the horn, either first or second. Thus the chord of low B b, can be written: First horn in low B b:

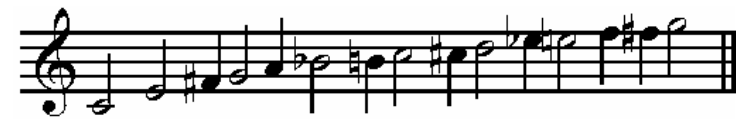

effect:

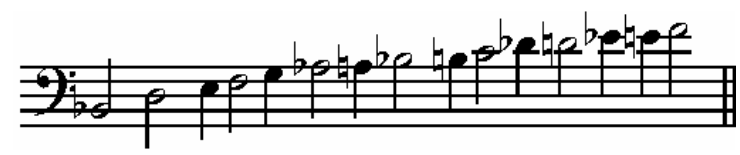




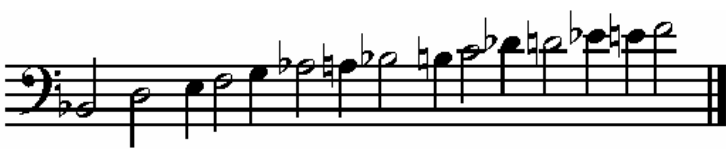

Cor $2^{\mathrm{e}}$ en $\mathrm{Si} b$ grave:

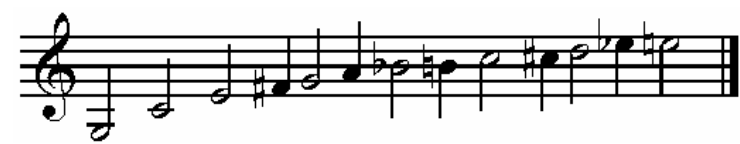

effet:

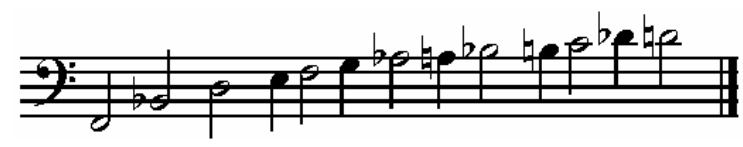

Les notes écrites avec des blanches, ont un son clair et plein; les noires au contraire, ont un son plus sourd, et ne doivent servir que dans la plus grande nécessité et plutôt encore dans un solo que dans les tutti.

Cela s'applique à tous les exemples suivans.

L'accord en $U t$ est exactement, une octave plus bas que le violon ou la clarinette en $U t:$

Cor $1^{\mathrm{er}}$ en Ut:

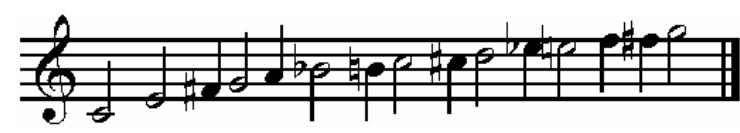

effet:

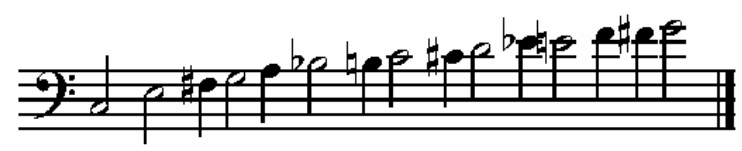

Second horn in low B $b$ :

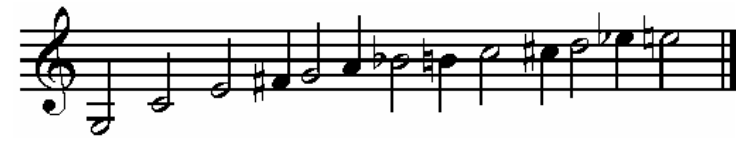

effect:

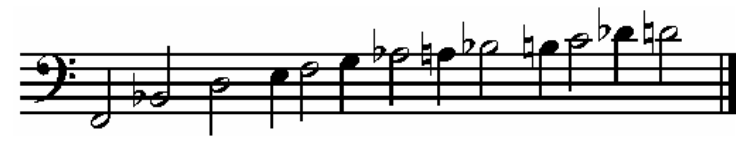

The white notes have a clear and full

sound; the black ones on the contrary, have a muffled sound, which must be used only when in the greatest need and in a solo rather than in tutti.

That applies to all the known examples.

The chord in $\mathrm{C}$ is exactly one octave lower than the violin or the clarinet in $\mathrm{C}$.

First horn in C:

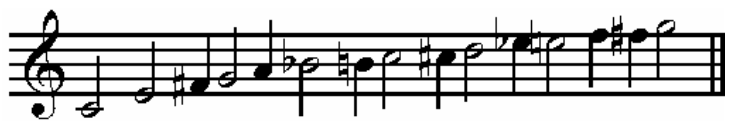

effect:

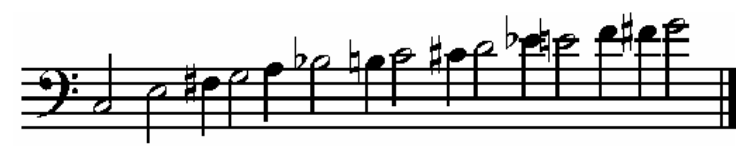


Cor $2^{\mathrm{e}}$ en Ut:

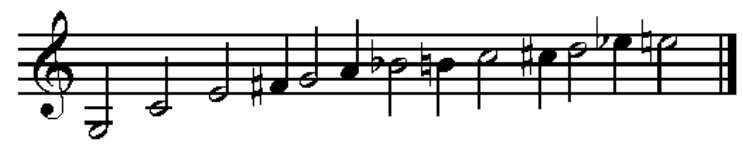

effet:

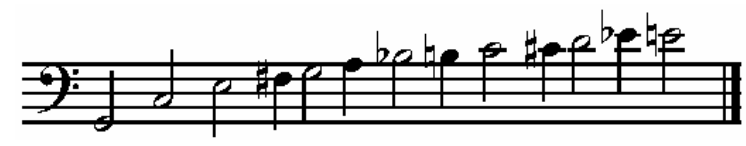

L'accord en Ré est une septième mineure

plus bas que le violon ou la clarinette en

Ut.

Cor $1^{\text {er }}$ en Ré:

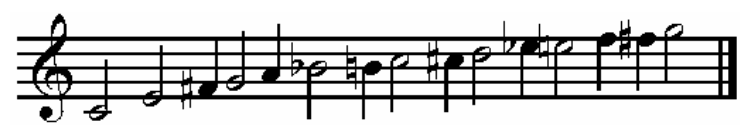

effet:

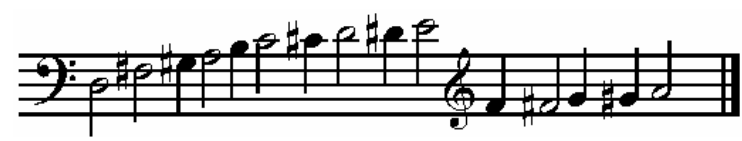

Cor $2^{\mathrm{e}}$ en Ré:

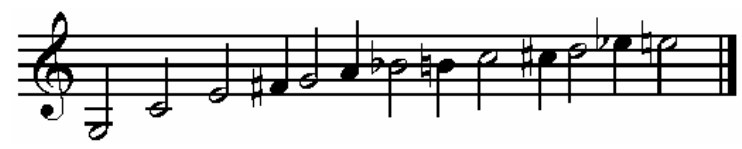

effet:

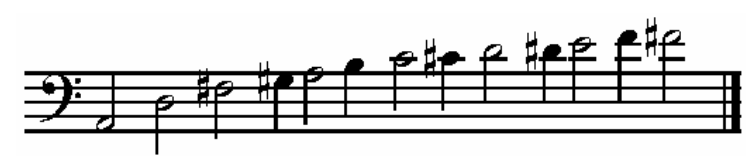

L'accord en $M i b$ est d'une sixte majeure

plus bas que le violon ou la clarinette en

$U t:$

Second horn in C:

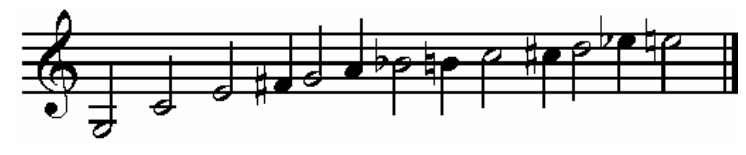

effect:

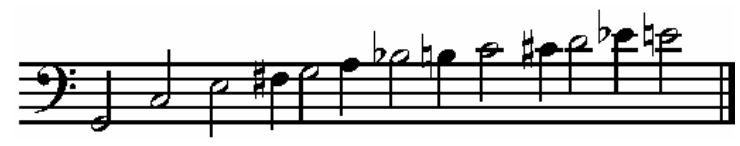

The chord in D is a minor seventh lower

than the violin or the clarinet in $\mathrm{C}$.

First horn in D:

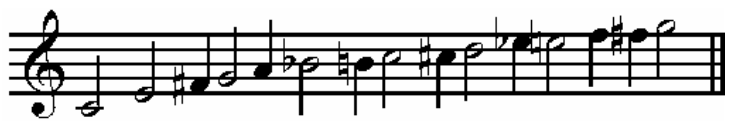

effect:

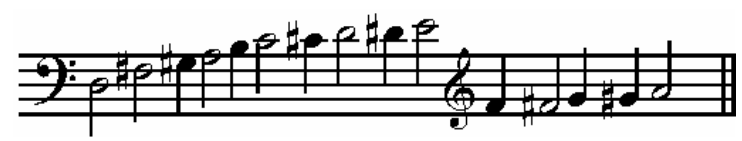

Second horn in D:

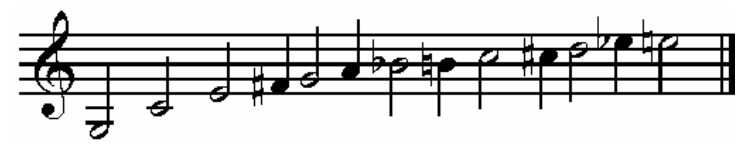

effect:

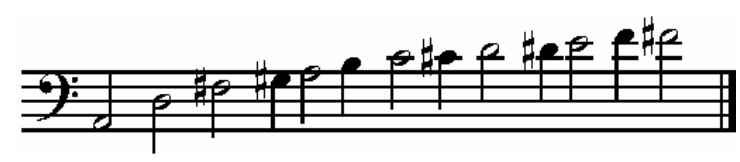

The chord in $\mathrm{E} b$ is a major sixth lower

than the violin or the clarinet in $\mathrm{C}$. 
Cor $1^{\text {er }}$ en Mib:

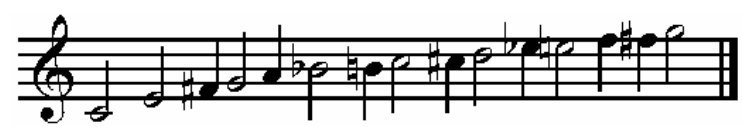

effet:

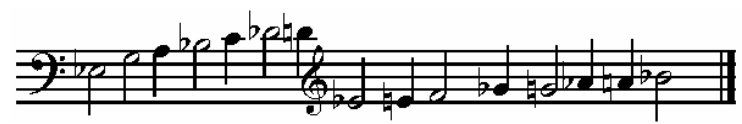

Cor $2^{\mathrm{e}}$ en Mib:

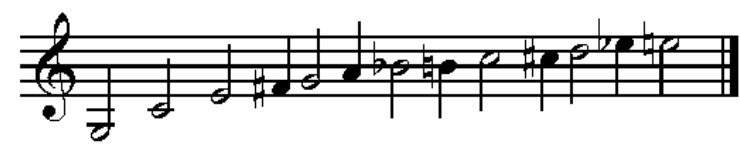

effet:

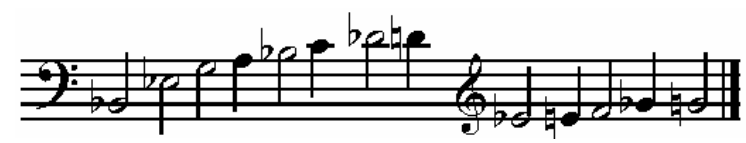

L'accord en $M i$ est d'une sixte

mineure plus bas que le violon ou la clarinette en $U t$ :

Cor $1^{\text {er }}$ en Mi:

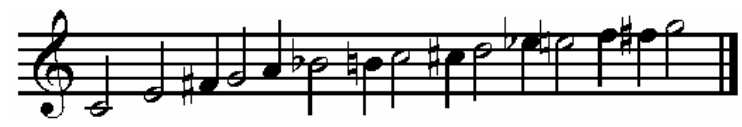

effet:

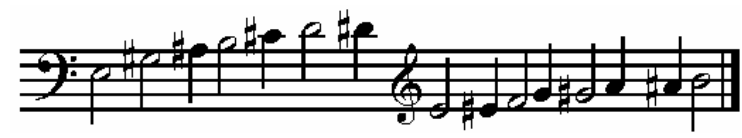

Cor $2^{\mathrm{e}}$ en $\mathrm{Mi}$ :

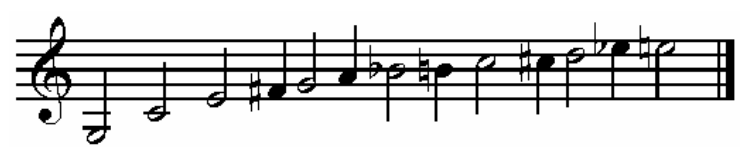

First horn in E b:

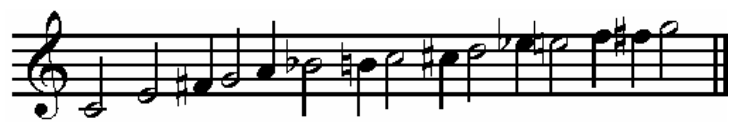

effect:

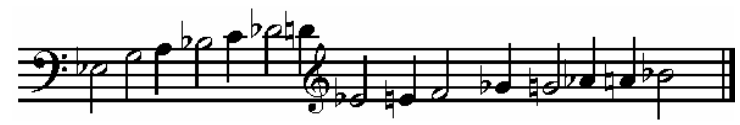

Second horn in $\mathrm{E} b$ :

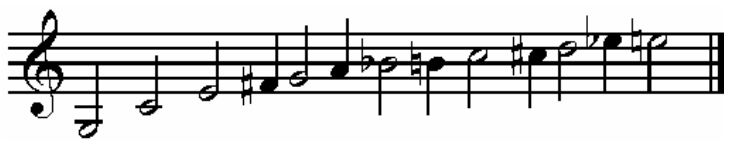

effect:

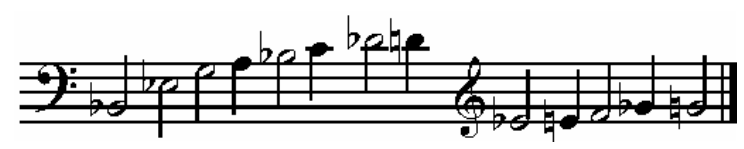

The chord in E is a minor sixth lower

than the violin or the clarinet in $\mathrm{C}$.

First horn in E:

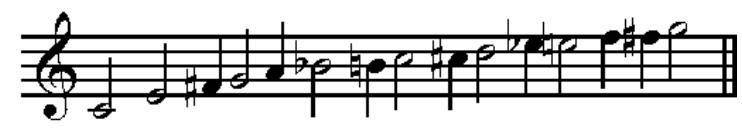

effect:

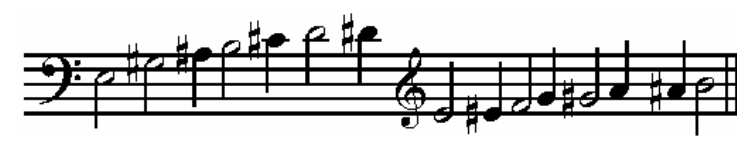

Second horn in E:

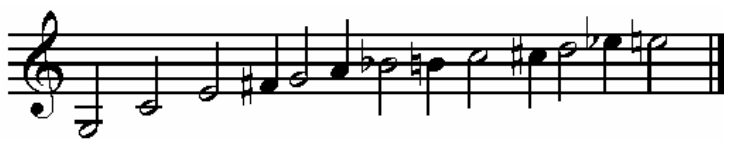


effet:

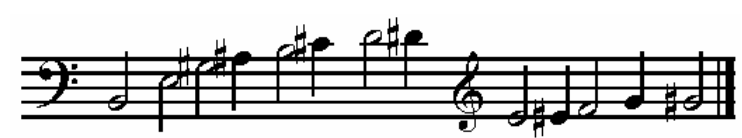

L'accord en $F a$ est s'une quinte parfaite

plus bas que le violon ou la clarinette en

$U t:$

Cor $1^{\text {er }}$ en Fa:

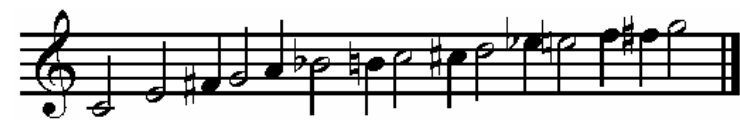

effet:

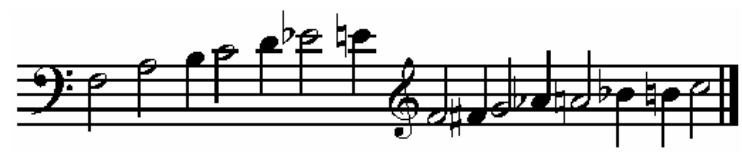

Cor $2^{\mathrm{e}}$ en $\mathrm{Fa}$ :

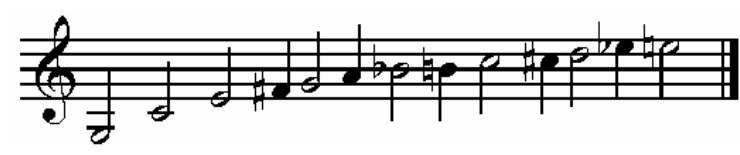

effet:

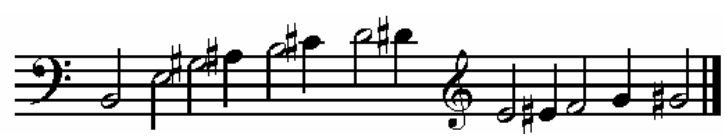

effect:

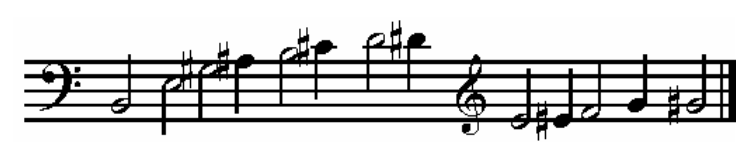
than the violin or the clarinet in $\mathrm{C}$.

First horn in F:

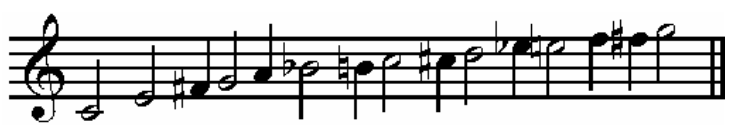

effect:

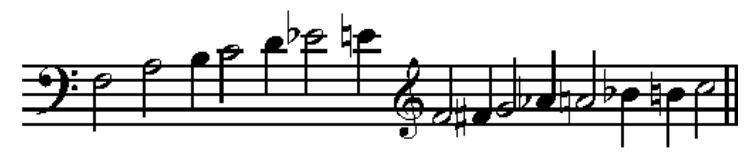

Second horn in F:

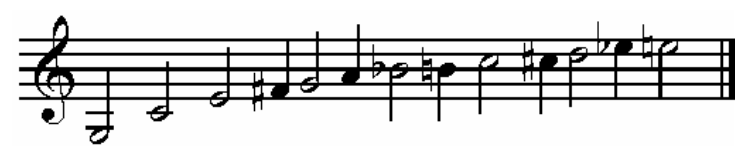

effect:

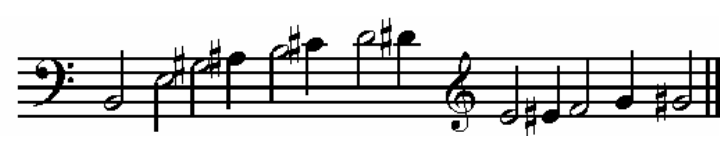

L'accord en Sol est d'une quarte juste plus The chord in G is a perfect fourth lower bas que le violon ou la clarinette en $U t$ : than the violin or the clarinet in C: Cor $1^{\text {er }}$ en Sol: First horn in G 


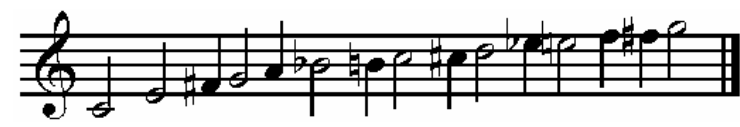

effet:

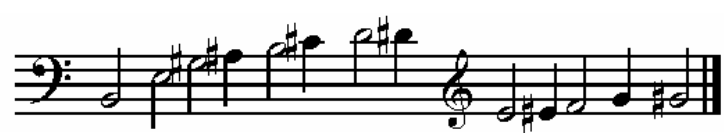

Cor $2^{\mathrm{e}}$ en Sol:

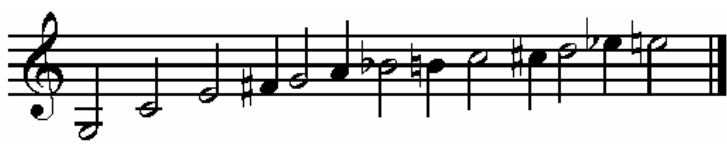

effet:

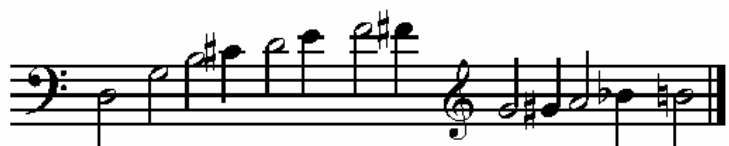

L'accord en La est d'une tierce mineure

plus bas que le violon et par conséquent à

l'unisson, avec la clarinette en $L a$ :

Cor $1^{\text {er }}$ en La:

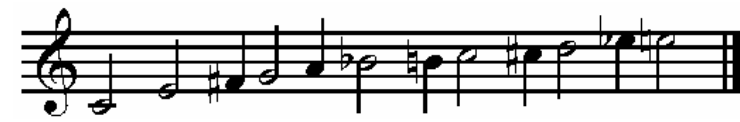

effet:

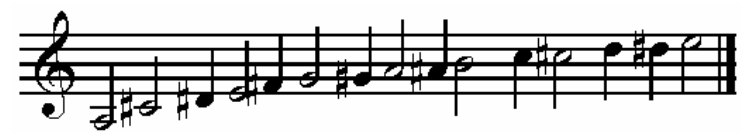

Cor $2^{\mathrm{e}}$ en La:

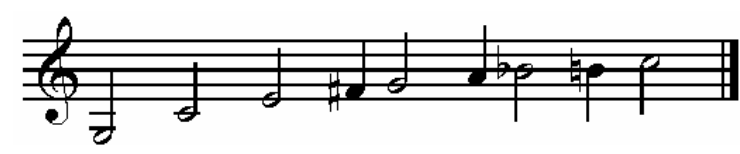

effet:

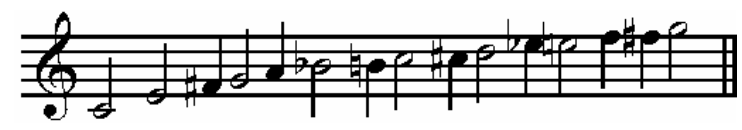

effect:

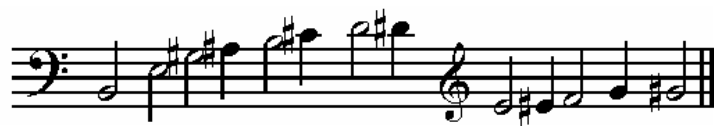

Second horn in G:

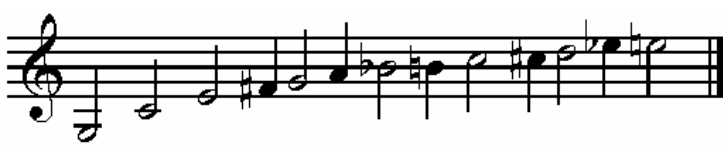

effect:

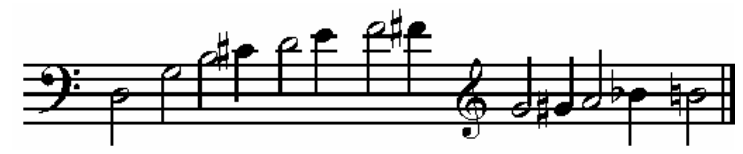

The chord in $\mathrm{A}$ is a minor third lower

than the violin, and consequently in

unison with the clarinet in A:

First horn in A:

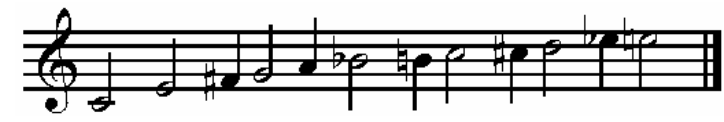

effect:

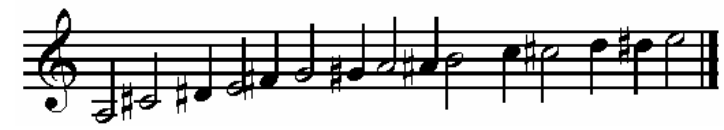

Second horn in A:

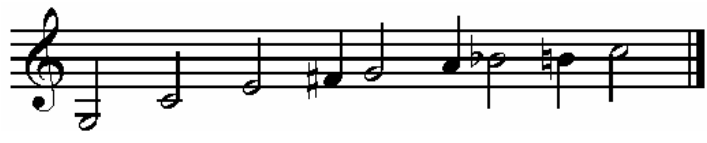

effect: 


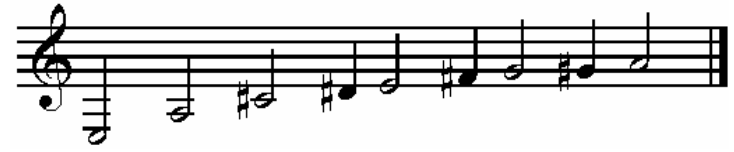

L'accord suivant est appelé en Si b haut, ou

Sib alto, pour ne pas le confondre avec

l'accord en $\mathrm{Si}$ b grave; il est d'une octave

plus haut que ce dernier accord, et ainsi

seulement d'un ton plus bas que le violon

ou la clarinette en $U t$, et par conséquent à

l'unisson avec la clarinette en $\mathrm{Si}$.

Cor $1^{\mathrm{er}}$ en Sib haut:

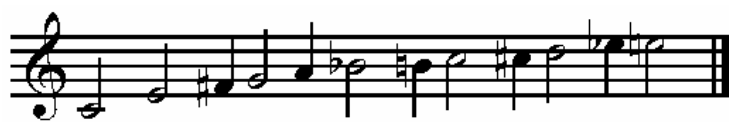

effet:

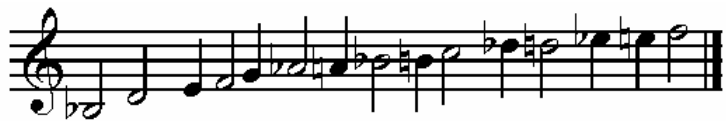

Cor $2^{\mathrm{e}}$ en Sib haut:

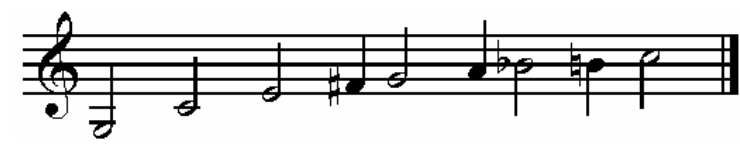

effet:

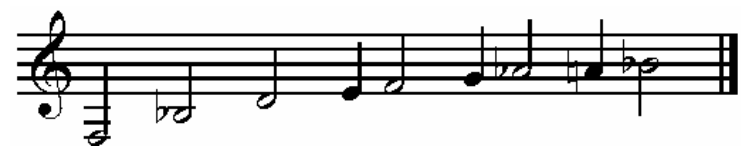

Outre cela on a quelquefois besoin des

accords: $L a b, R e ́ b, S o l b$, et $S i \#$; les corps

de rechange qui correspondent à ces

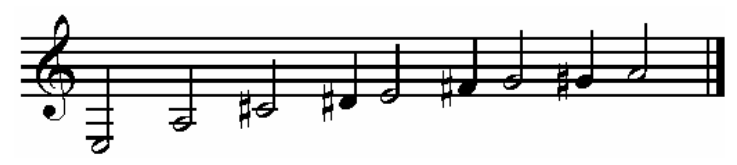

The following chord is called high $\mathrm{B} b$ or

alto $\mathrm{B} b$, so that it will not be confused

with the chord in low $\mathrm{B} b$; it is an octave

higher than this last chord, and thus only

one tone lower than the violin or the

clarinet in $\mathrm{C}$, and consequently in unison

with the clarinet in $\mathrm{B} b$.

First horn in high $\mathrm{B} b$ :

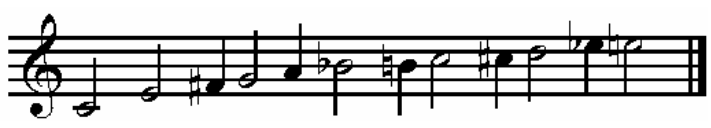

effect:

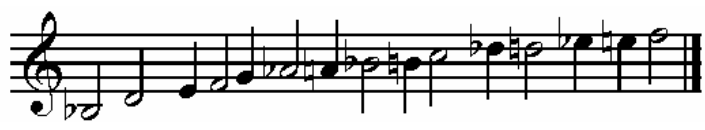

Second horn in high $\mathrm{B} b$ :

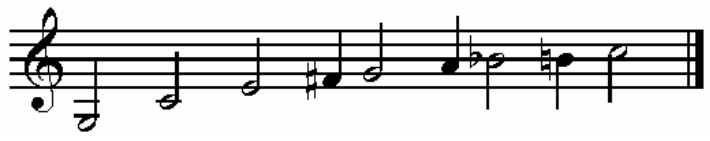

effect:

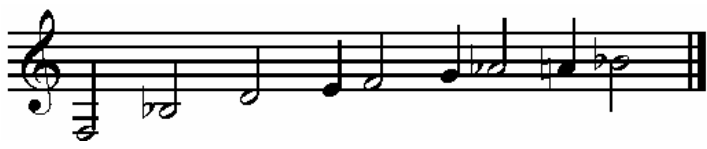

In addition, there is sometimes a need for these chords: $A b, D b, G b$, and $B \#$; the crooks which correspond to these chords 
accords n'existant que rarement, l'artiste y supplée en tirant la coulisse qui est adaptée à l'instrument, mais l'effet n'en est qu'imparfait et doit s'éviter autant que possible.

Dans les corps de rechange hauts $L a$, et $S i b$ alto, les tons les plus élevés sont déjà difficiles et d'une exécution douteuse, il faut donc, si on le peut, se borner aux notes du médium et du grave.

Sur le second cor on peut au besoin donner un $U t$ grave, mais on ne s'en sert ordinairement que, lorsque le premier cor a l'octave supérieure; les deux tons s'écrivent dans la partition à la clef de $S o l$ 2. ${ }^{\text {me }}$ ligne, et aussi quelquefois à la clef de Fa 4. ${ }^{\text {me }}$ ligne; Exemple:
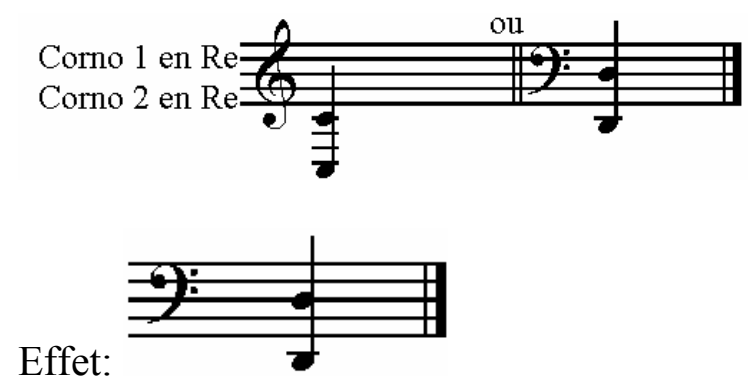

Ceci a lieu dans tous les accords; par are rarely available; the artist

compensates for this by pulling the slide that is attached to the instrument, but the effect is imperfect and must be avoided as much as possible.

Using the crooks for the high and alto A and $\mathrm{B} b$, the highest tones are already difficult and weak in their execution; it is thus necessary, if possible, to limit such notes to the medium and the low register. On the second horn, it may be necessary to play in low $\mathrm{C}$, but usually one uses it only when the first horn is in the higher octave; both keys are indicated on the score and written on the part on the treble clef, and sometimes also on the bass clef, for example:

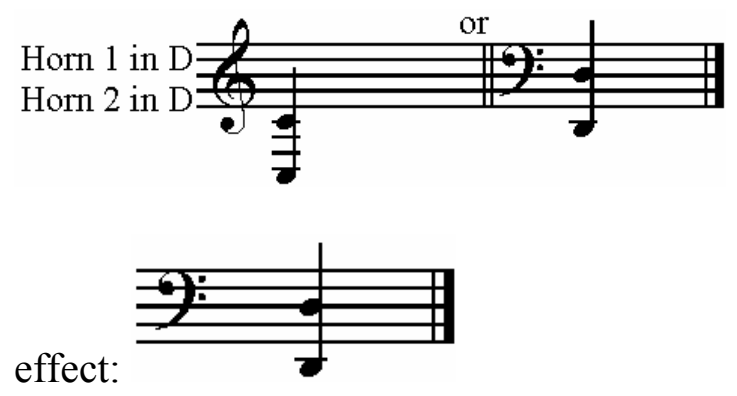

This takes place in all the chords; for 
exemple, dans l'accord de $F a$ :

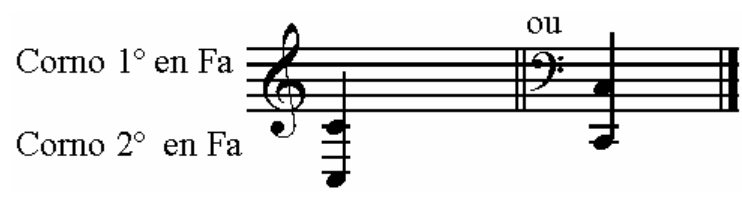

effet:

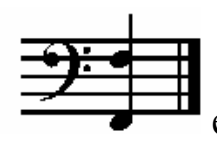

et ainsi des autres.

Cet Ut grave ne peut s'exécuter que

comme note tenue, il ne doit pas changer

rapidement avec d'autres tons, et encore,

ne s'en sert-on que par exception.

Il résulte de là que le cor ne présente que

peu de sons dont on puisse attendre un

effet conforme au but, et ceux qui

remplissent cette condition ne sont

généralement que les notes indiquées en

blanches. On ne peut en obtenir que des

figures d'un aspect fort simple, mais qui

ne laissent pas de produire un fort bel

effet, à cause du timbre plein de

l'instrument, si on sait les employer à

propos. example, in the chord of $\mathrm{F}$
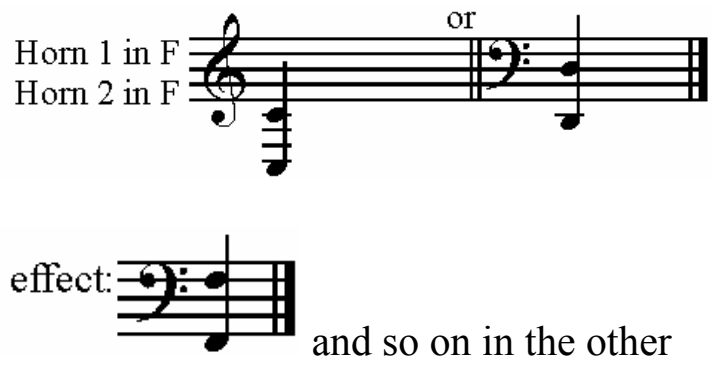

chords.

This low $\mathrm{C}$ can be played only as a

sustained note; it should not be quickly

interchanged with other notes, and

moreover, one makes use of it only

occasionally.

Thus, one can expect the horn to produce

only a few sounds that conform to the

intended goal; those that do are generally

only those notes that have been indicated as half notes. From these, only extremely simple figures can be obtained; however if one knows how to use the instrument correctly, a very pretty effect can be produced, due to the full timbre of the instrument.

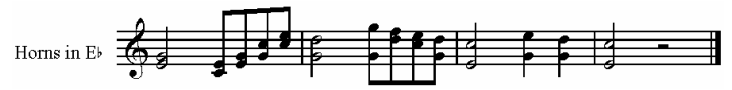




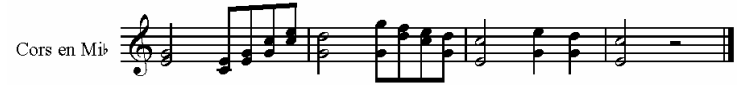

Il faut seulement observer que les corps de It should surely be observed that the high rechange élevés n'atteignent pas crooks do not easily reach this height; facilement à cette hauteur; ces figures ne thus these figures should not appear doivent donc pas paraître souvent, il faut often; rather, it is necessary to use held plutôt employer des notes tenues; ainsi, notes. Thus, a simple octave supported une simple octave soutenue par deux cors by two horns gives much relief to the donne beaucoup de relief à l'harmonie. harmony. Les tons notés avec des noires, dans les The tones notated with the quarter notes exemples précédens $M i$ bet $L a$, peuvent au in the preceding examples $\mathrm{E} b$ and A can besoin servir pour des sons soutenus, mais be useful as supported sounds, but not too pas trop souvent; de même les notes: $U t \sharp, \quad$ often; and in addition these notes: $C \sharp, B$ $S i$ et $F a \#$, doivent s'écrire de manière à se and $F \#$, must be written so as to connect lier facilement au son qui est un degré plus easily to the sound the next degree haut, et cette liaison s'effectue toujours higher; this connection is always played avec un des tons que nous avons désignés with one of the tones which we indicated ci-dessus par des blanches; par exemple: with half notes above, for example:
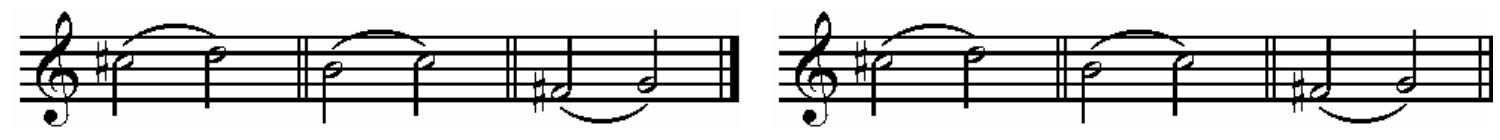

On peut aussi en faire usage en les renversant si elles suivent immédiatement un des tons désignés comme bons; par exemple:
One can also use it by reversing them, if they immediately follow one of the keys designated as good, for example: 


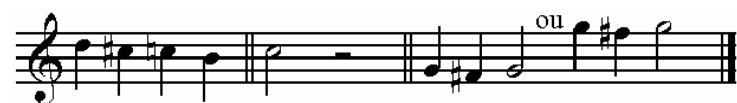

Aussi, le La b fait-il bon effet en se

résolvant au Sol; Exemple:

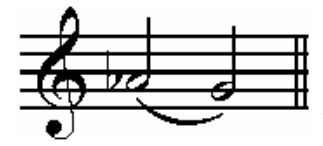

les tons suivans:

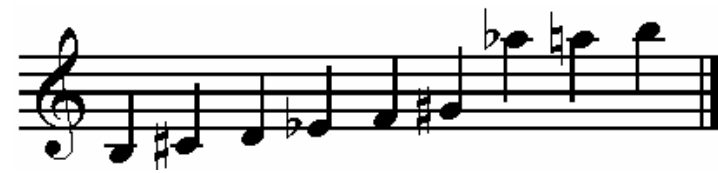

qui ne sont pas notés au cor produisent

ordinairement un mauvais effet ou n'en

produisent pas du tout; on ne doit donc pas

les employer, car il n'y a qu'un très bon

artiste qui puisse les exécuter d'une

manière satisfaisante.

Quand un cor a la septième de l'harmonie, on fait souvent sauter cette septième, si le ton dans lequel il doit se résoudre, d'après les règles de l'harmonie, n'est pas un de ceux qui sont désignés comme bons:

Cor en Ut

Orchestre.

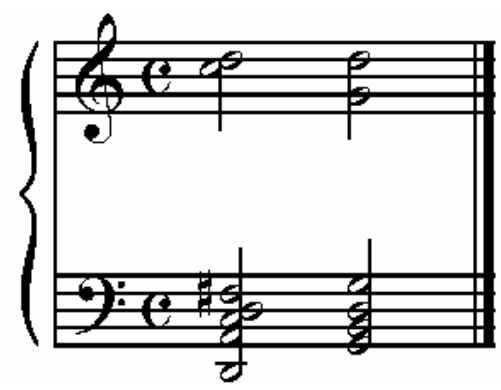

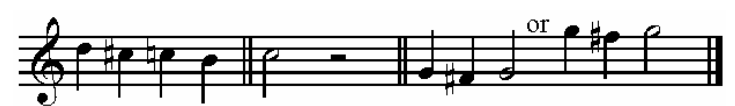

Also, the A $b$ has a good effect when resolving to $\mathrm{G}$, for example:
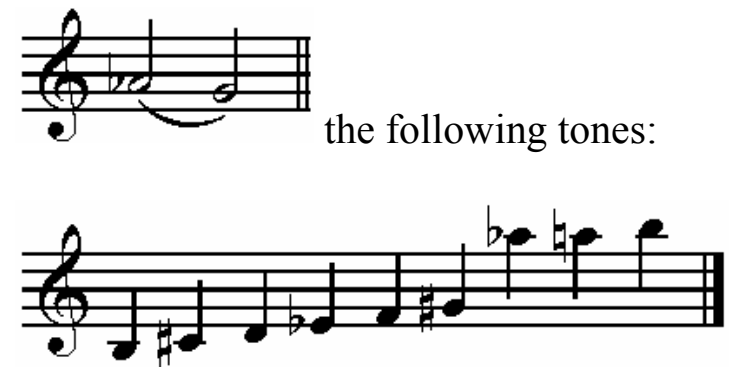

that are not noted with the horn usually

produce a bad effect or do not produce

any at all; thus one should not use them, because there is only one very good artist

who can play them in a satisfactory

manner.

When a horn has the harmony's seventh, one often skips this seventh, if the key to which it must be resolved, according to the rules of harmony, is not one of those which are designated as good:

Hom in $\mathrm{C}$

Orchestra

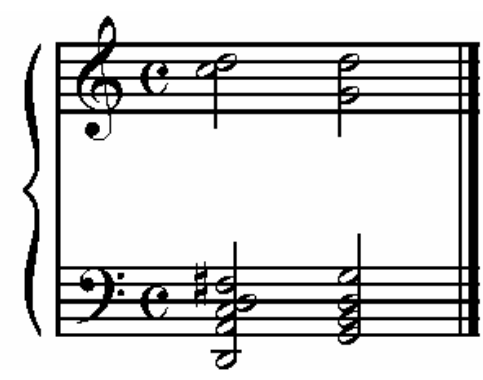


Dans cet exemple, l'Ut représente la

septième qui doit sauter; seulement, il est

alors nécessaire, qu'un autre instrument

par lequel cette septième a été doublée, la

résolve d'une manière juste, ou bien que le

$S i$ du second accord arrive par une autre

progression, ne pouvant pas manquer tout-

à-fait en qualité de tierce de l'harmonie. ${ }^{125}$

Voici un exemple où ce saut n'est pas

nécessaire, parceque le son dans lequel

doit se résoudre la $7 .{ }^{\text {me }}$ est bon sur le cor:

Cor en Ut

Orchestre.

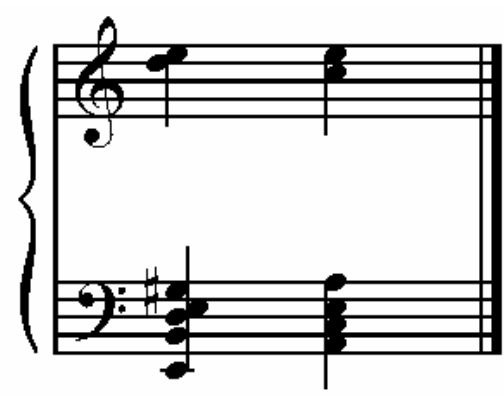

Souvent on est obligé de faire marcher les

cors d'une manière qui n'est pas

précisément fautive, d'après les règles de

la composition, mais qui n'est cependant

pas coulante; par exemple:
In this example, $\mathrm{C}$ represents the seventh which must be skipped over; only it is then necessary, that another instrument by which this seventh was doubled resolves it correctly; or, although B of the second chord is achieved by means of another progression, it is not completely lacking in quality in its capacity as the third of the harmony.

Here is an example where this jump is not necessary, because on the horn, the sound in which the seventh must be resolved is of a good effect:

Horn in C

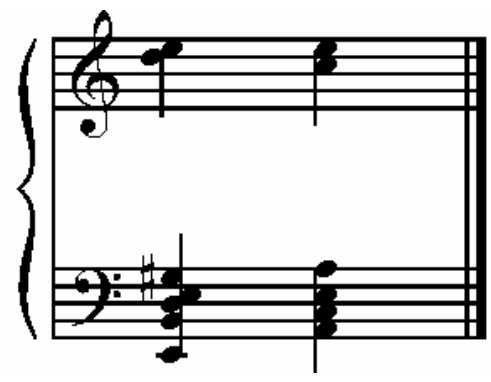

One is often obliged to have the horns play in a manner which is not exactly incorrect, according to the rules of composition, but which however does not flow well; for example: 
Cor en Ut

Orchestre.

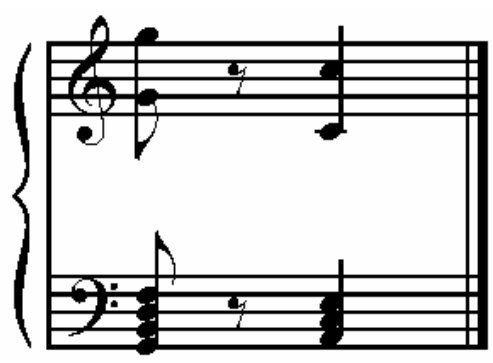

La défectuosité de certains sons dans le cor excuse cette licence, surtout dans le cas où les accords sont séparés par des pauses.

Des sons donnés très rapidement l'un après l'autre, sont d'une exécution facile:

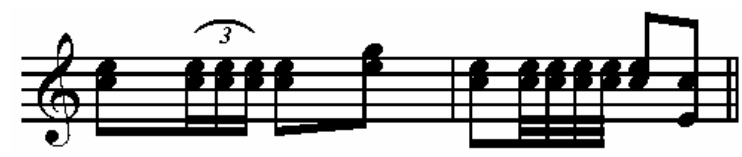

Et font surtout con effet, lorsque les cors

sont réunis à la masse des autres

instrumens en cuivre; au contraire, si les

cors ne jouent qu'avec le quatuor (les

violons), ou avec les instrumens à vent en

bois, des notes piano tenues et long-tems

prolongées dans le même ton, produisent

un très bon effet.

Les cors s'emploient aussi très souvent

dans l'orchestre et la musique militaire, par quatre; on en fait ordinairement jouer
Horn in C

Orchestra

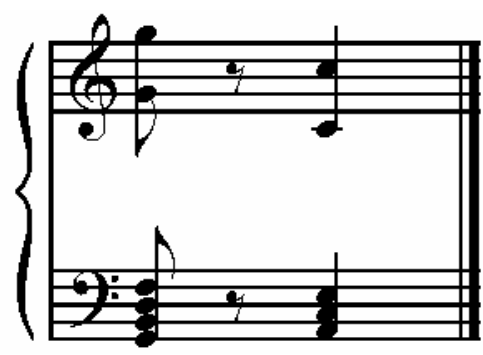

The defect of certain sounds in the horn

excuses this license, especially if the

chords are separated by pauses.

Sounds produced very quickly one after

the other are easy to execute:

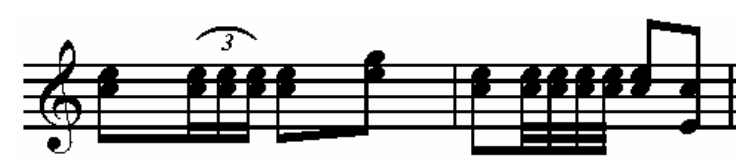

This makes an especially silly effect,

when the horns are played along with the

mass of the other brass instruments, they

produce an especially bad effect; on the

contrary, if the horns play only with the

quartet (of violins), or with the woodwind

instruments, sustained piano notes

prolonged in the same key produce a very

good effect.

The horns are also very often used in

military and orchestral music, in a group

of four; one usually has two of them play 
deux dans le ton primitif, et deux à la

quinte inférieure; par exemple, deux cors

en $U t$ et deux en $F a$; ou deux en $M i b$, et

deux en $\mathrm{Sib}$ alto; ou bien un en Sib alto et

l'autre en $\mathrm{Sib}$ grave; et encore autrement

selon que les tons dont on veut se servir le

rendent nécessaire; ce qu'il faut

naturellement calculer d'avance.

Dans les tons mineurs, on fait jouer

ordinairement deux des cors dans le ton du

morceau, et les deux autres dans le ton

relatif majeur; c'est-à-dire une tierce

mineure au dessus du ton dans lequel le

morceau est écrit; par exemple: Si le

morceau est en Ré mineur, on écrit deux

cors dans le ton de Ré et les deux autres

dans le ton de $F a$; mais, si l'on n'a que

deux cors on écrit le second dans le ton du

morceau et le premier dans le ton relatif

majeur; ainsi, en Ré mineur le second cor

doit jouer en Ré et le premier en $F a$.

Une autre manière de s'en servir dans les in the tonic key, and two in the lower

fifth, for example: two horns in $\mathrm{C}$ and

two in $\mathrm{F}$; or two in $\mathrm{E} b$, and two in alto

$\mathrm{B} b$; or one in alto $\mathrm{B} b$ and the other in

low $\mathrm{B} b$; other combinations are perhaps

also necessary, depending on whether the

key that one wishes to use requires it;

which one must naturally calculate in

advance.

In the minor keys, one ordinarily writes

for two of the horns in the key of the

piece, and the two others in the relative

major key; in other words a minor third

above the key in which the piece is

written; for example: If the piece is in $\mathrm{D}$

minor, one writes two horns in the key of

$\mathrm{D}$ and the two others in the key of F;

however, if there are only two horns one

writes the second in the key of the piece

and the first in the relative major key;

thus, in D minor the second horn must

play in $\mathrm{D}$, and the first in $\mathrm{F}$.

Another manner of using the horns in the 
tons mineurs, en prenant deux cors en Sol, et les deux autres en $U t$ majeur, on trouvera très bien presque toutes les notes nécessaires au ton de Sol mineur.

Il ne faut pas souvent écrire de trilles pour

le cor, parceque la plupart sont d'une

exécution difficile et de peu d'effet; ceux

qu'on peut le mieux employer, sont les

suivans:

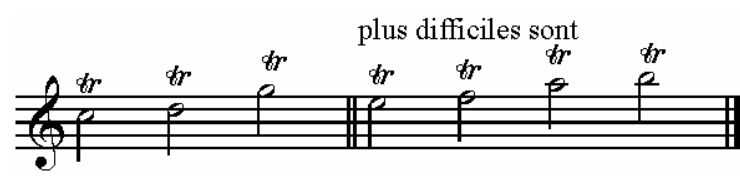

Il faut observer: 1. ${ }^{\circ}$ Que les trilles sur les sons bouchés sont moins brillans $[$ sic $]$ que sur les sons naturels, et pour cette raison, on ne doit les employer que dans les solos.

2. ${ }^{\circ}$ Qu'il est impossible d'exécuter les trilles élevés sur les corps de rechange hauts; ainsi, sur les corps de rechange $S i$ b alto, $L a$, ou Sol, on ne peut pas écrire les

trilles suivans:

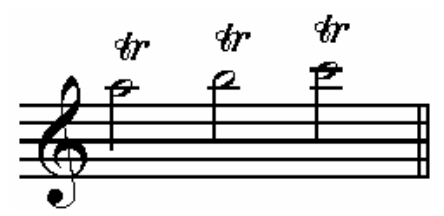

parceque, dans ces accords, comme nous minor keys is to write two of them in $G$ and the other two in $\mathrm{C}$ major; one will easily find almost all the necessary notes in the key of $\mathrm{G}$ minor.

One should not write trills for the horn often, because the majority are difficult to execute and of little effect; the following trills are those which can be used to the best effect:

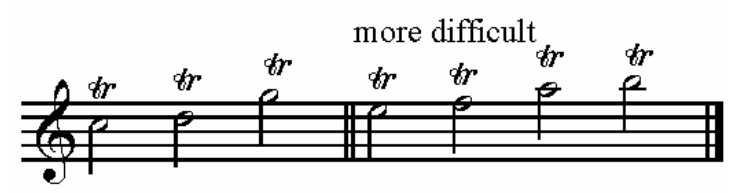

It is necessary to observe:

1. That the muted trills are less brilliant than the natural trills; for this reason, one should only use them in the solos.

2. That it is impossible to play high trills on the high crooks; thus, on the alto $\mathrm{B} b$, A or $\mathrm{G}$ crooks one cannot write the

following trills:

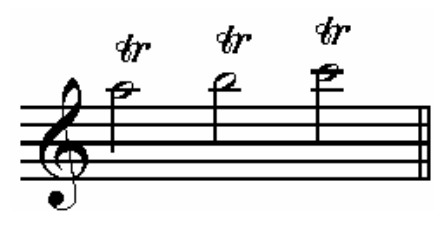
because the keys in these chords, as we have already said, are much too high; 
l'avons déjà dit, les tons étant beaucoup trop élevés, il n'y a que des artistes très habiles qui peuvent les exécuter; on ne doit donc pas s'en servir.

Sil est nécessaire de changer de ton dans un morceau, il faut faire précéder de plusieurs pauses l'instant où le cor doit commencer à jouer dans le nouveau ton, afin que l'artiste ait le tems de changer d'accord.

Lorsqu'on a quatre cors, on peut très commodément faire changer de ton à deux, tandis que les autres continuent à jouer; et, quand l'opération est finie pour les premiers, on fait changer les deux seconds, si, toutefois, le morceau l'exige.

Les tons du cor favorables au solo sont: Ré, $M i$ b , Mi, Fa, plus rarement $S o l$, parceque cet accord est déjà très haut. Cependant, on a déjà joué des morceaux très brillans dans cet accord. ${ }^{126}$ only very skilful artists can play them; thus one should not use these trills.

If it is necessary to change keys in a piece, one must precede the horn's key change with several pauses, so that the artist has time to change chords.

When one has four horns, one can very conveniently have two of them change keys, while the others continue to play; and, when the key change has been finished by the first two horns, the second two may change keys as well, if should the piece require it. The pitches of the horn suitable for solos are: $\mathrm{D}, \mathrm{E} b, \mathrm{E}, \mathrm{F}$ and, more rarely, G; this chord is already very high. However, some very brilliant pieces of music have already been played in this chord. 
Nous avons des Méthodes de cor de

Domnich, Duvernoy, Frowhlich, Chalon,

Dauprat, Meifred, (Méthode acceptee par

le Conservatoire) Mengal, Iahn, Kling,

Punto et autres. ${ }^{127}$

\section{LE COR DE CHASSE ou TROMPE.}

Cet instrument s'écrit de mème que le cor sur la clef de Sol, 2. ${ }^{\text {me }}$ ligne, mais on le tient de la main droite et comme on n'y fait pas de tons bouches, cet instrument ne donne que les notes suivantes:

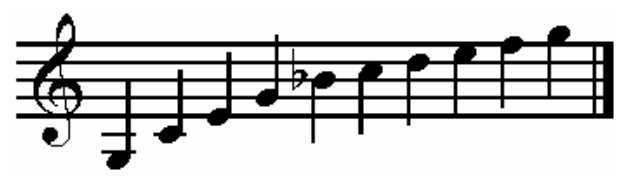

Cet instrument n'avant pas de corps de rechange, on n'écrit pas à la clef trompe en Ré on trompe en $U t$, car pour chaque ton différent il faut prendre un autre instrument. Les cors de chasse les plus ordinaires sont en $U t$, Ré, ou Mib.

Quelque rétréci que soit le cercle des notes qu'on puisse parcourir sur le cor de chasse, on ne laisse pas quelquefois d'y produire
We have methods of horn by Domnich, Duvernoy, Frowhlich, Chalon, Dauprat, Meifred (method accepted by the Academy), Mengal, Iahn, Kling, Punto and others.

\section{THE HUNTING HORN}

This instrument is, like the horn, written on the treble clef, but one holds it with the right hand, and as one does not play any muted tones on it, this instrument gives only the following notes:

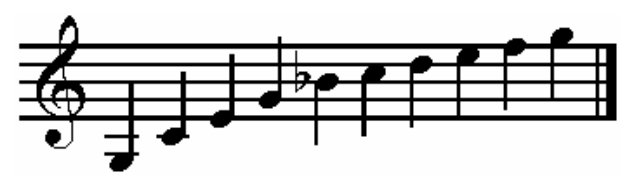

This instrument does not have a crook, one does not write "horn in D" or "horn in C", because for each different key it is necessary to use another instrument. The most ordinary hunting horns are in C, D or $\mathrm{E} b$.

Although the number of notes the hunting horn can produce is limited, one sometimes does not allow this instrument 
des mélodies d'un très bon effet, comme

par exemple Rossini en a trouvées dans

son rendez-vous de chasse où l'on

remarque un chant original et

merveilleusement nuancé. ${ }^{128}$

\section{LE COR A PISTONS.}

La plupart des difficultés qui existent pour

le cor sont surmontées par le cor à pistons

qui a les sons du cor ordinaire, mais auquel

on a adapté deux ou trois pistons au moyen

desquels on peut donner avec plénitude et

la plus grande précision tous les sons

sourds et douteux sur le cor ordinaire; par

exemple les sons:

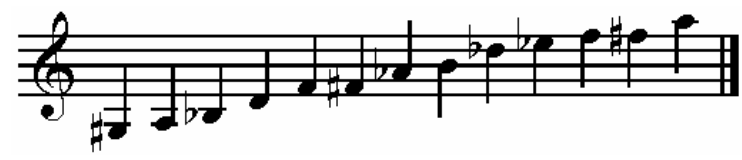

Qui sur le cor ordinaire sont sourds et

douteux, deviennent sur le cor à pistons

justes et pleins comme les autres sons

naturels du cor ordinaire, excepté toutefois

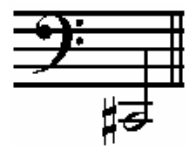

de l'octave inférieure. to create melodies of a very good effect,

for example: in Rossini's hunting rendez-

vous, one notices an original and

marvelously nuanced song.

\section{THE VALVE HORN}

Most of the difficulties which exist for

the horn are overcome by the valve horn, which produces the same sounds of the ordinary horn, but to whichtwo or three pistons have been adapted, creating full and highly accurate sounds, for example:

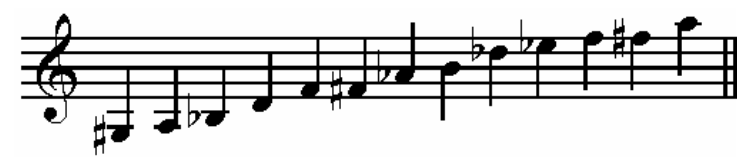

Sounds that are muffled and of dubious

effect on the ordinary horn become true and full on the valve horn-like the ordinary horn's other natural sounds,

excepting however:

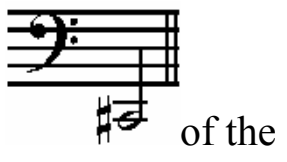

lower octave. 
Mais il est à regretter que cet instrument ne soit pas encore généralement adopté, parceque l'on pourrait produire avec lui de fort bons effets.

Les pistons ont la propriété de baisser l'instrument d'une tierce mineure et de donner trois tons ou corps de rechange fictifs, différens, qui ajoutés à celui qui est sur la grande coulisse les met au nombre de quatre. Si on a par exemple; le corps de rechange $F a$, les autres tons seront $M i$, Mib, Ré, avec lesquels il est facile de former tous les autres; (c'est ainsi qu'est construit le cor à pistons en Allemagne); mais, l'expérience a prouvé qu'il était difficile de produire avec ce seul corps de rechange les tons aigus; $S o l, L a$, $S i b$, et les tons graves: $U t, S i b$; que le timbre des premiers n'était pas si brillant, que celui des seconds manquait de volume et perdait beaucoup de son caractère particulier, et c'est pour cela qu'on a conservé tous les corps de rechange du cor ordinaire pour le
But, it is regrettable that this instrument hasnot yet been generally adopted; with its use, one could create very good effects.

The pistons lower the instrument by a minor third, and produce three keys or different crooks; the addition of the large slide raises that number to four. For example, if one has the F crook, the other key will be E, E b, D; with these, it is easy to form all the others (in Germany, the valve hornwas built in the same manner); however, experience has shown that it was difficult to produce the high keys $(\mathrm{G}, \mathrm{A}, \mathrm{B}$ b) and the low keys $(\mathrm{C}$, $\mathrm{B}$ b) with this crook alone; as the timbre of the first groupwas not very brilliant, and that of the second group lacked volume and lost much of its distinctive nature for this reason all the crooks of the ordinary horn were preserved on the valve horn, which, in this report, is being treated like the ordinary horn; if this is 
cor à pistons, qu'on traite sous ce rapport comme le cor ordinaire; et si l'on observe cela, on peut faire toutes les modulations avec d'excellentes notes. Il faut donc se servir du corps de rechange, dans les morceaux qui seraient écrits en: $S o l, L a$, Si b alto; Ré, Ut, Si b graves; à ces tons près le cor à pistons en $F a$, présente toutes les ressources possibles.

Comme tous les tons en sont bons, des passages tels que:

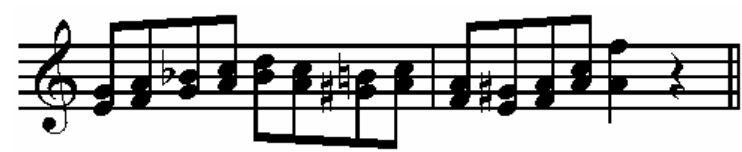

Produisent un très bon effet.

Nous avons de Mr. Meifred qui a perfectionné le cor à pistons, un ouvrage intitulé: de l'emploi et des ressources du cor en général, et de ses corps de rechange en particulier, avec quelques considérations sur le cor à pistons.

\section{LA TROMPETTE.}

Cet instrument est noté sur la clef de $\mathrm{Sol}$ closely observed, all the modulations can be made, and excellent notes produced. Thus, use of the crook is necessary in those pieces written in: alto $\mathrm{G}, \mathrm{A}, \mathrm{B} b$ or the low keys $\mathrm{D}, \mathrm{C}$, and $\mathrm{B} b$; in these keys the valve horn in $\mathrm{F}$ presents all possible resources.

As all its keys are good, passages such as:

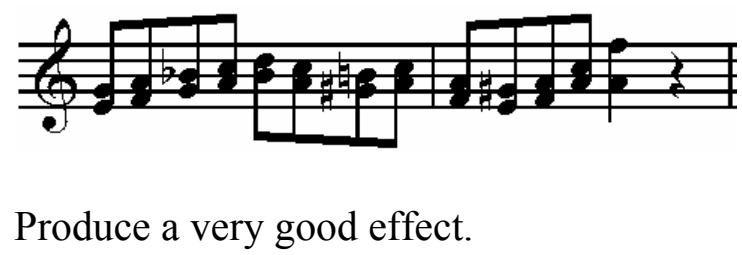

Produce a very good effect.

From Mr. Meifred, who improved the valve horn, we have a work entitled: use and resources of the horn in general, and its crooks in particular, with some considerations of the valve horn.

\section{THE TRUMPET}

This instrument is notated on the treble 
2. ${ }^{\text {me }}$ ligne; il s'écrit toujours en $U t$ majeur

parceque l'on y change l'accord comme

dans le cor; c'est pour cette raison qu'il

faut que l'accord y soit indiqué sur la

partition et la partie détachée.

L'entendue de la trompette est:

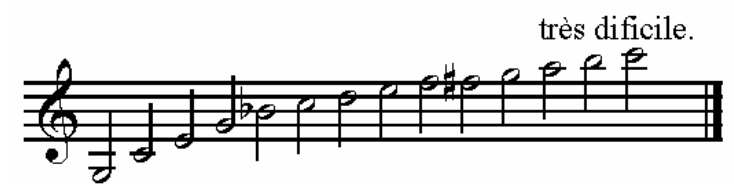

Mais les tons qui doivent servir dans

l'orchestre ou dans la musique militaire sont les suivans:

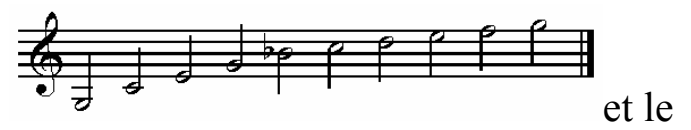

Exemple:

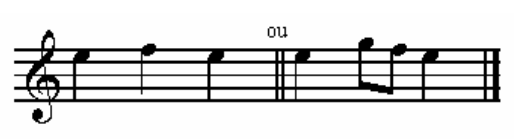

clef; it is always written in $\mathrm{C}$ major

because it is in this key that one changes

the chord (as one does on the horn); for

this reason, one must indicate the chord

both on the score and on the individual

part.

The range of the trumpet is:

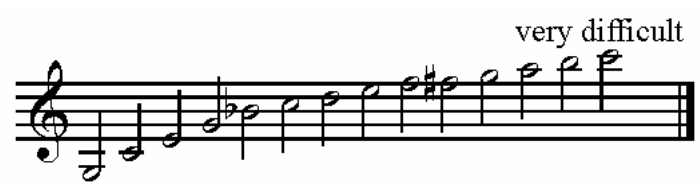

However, the following keys must be

used in orchestral or military music:

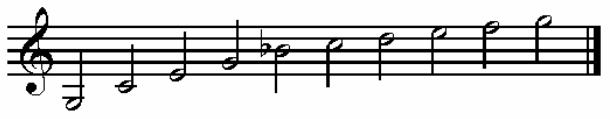

and

the is already very difficult to

play, if it is not preceded by an E or a G;

for example:

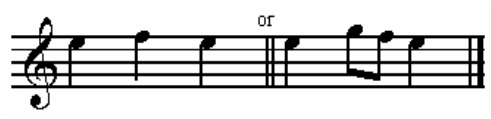

In the orchestra, there are usually two trumpets, a first and a second; the low crook for this instrument is in A; for 
instrument est en $L a$; Exemple:

$1^{\text {re }}$ Trompette en La.

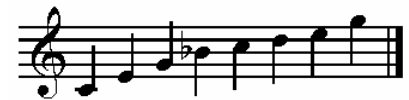

effet:

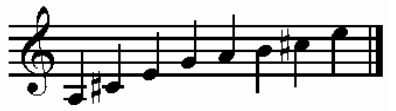

2e Trompette en La.

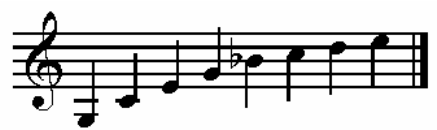

effet:

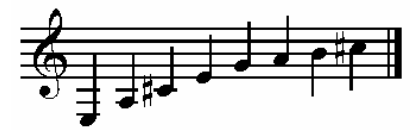

Ce qui prouve, que dans chaque accord la trompette produit encore moins de tons que le cor; ceux qu'on peut exécuter sont toujours écrits à gauche et leur véritable effet à droite. La trompette ci-dessus notée en $L a$, est d'une tierce mineure plus basse que le violon, et ainsi à l'unisson avec le cor en $L a$, ou la clarinette en $L a$.

La trompette en $\mathrm{Sib}$ est d'un ton entier plus basse que le violon ou la clarinette en $U t$, et à l'unisson avec le cor en Sib alto ou example:

First trumpet in A:

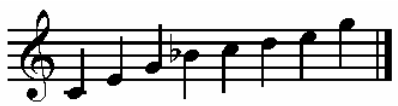

effect:

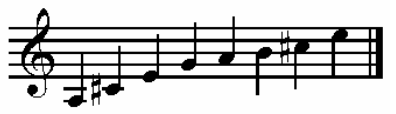

Second trumpet in A:

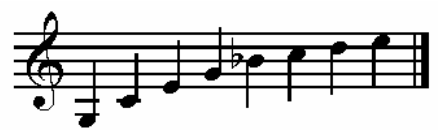

effect:

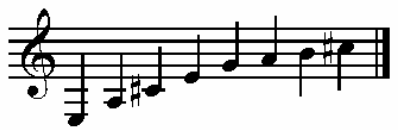

This proves that in each chord the trumpet produces even fewer notes than the horn; those which one can play are always written on the left, and their actual effect on the right. The trumpet in A, notated above, is a minor third lower than the violin, and thus is in unison with the horn in $\mathrm{A}$ or the clarinet in $\mathrm{A}$.

The trumpet in $\mathrm{B} b$ is a whole tone lower than the violin or the clarinet in $\mathrm{C}$, and is in unison with the horn in alto $\mathrm{B} b$ or with 
avec la clarinette en $\mathrm{Si}$.

$1^{\text {re }}$ Trompette en Sib.

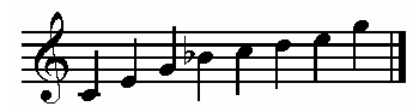

effet:

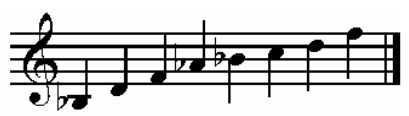

2. ${ }^{\mathrm{e}}$ Trompette en Sib.

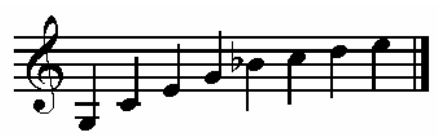

effet:

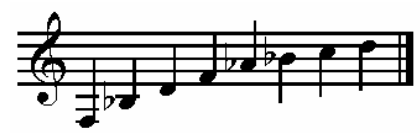

the clarinet in $\mathrm{B} b$.

First trumpet in B b :

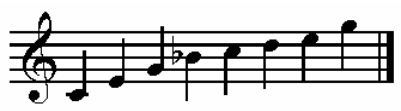

effect:

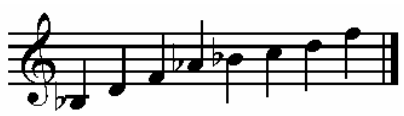

Second trumpet in $\mathrm{B} b$ :

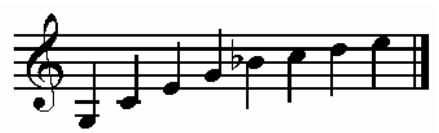

effect:

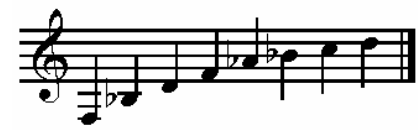

Dans la musique militaire les accords $L a$ et

Si b ne servent que rarement, tandis qu'au contraire tous les autres plus hauts y sont très usités.

Les meilleurs accords pour l'orchestre, sont; Ut, Ré, Mi b, Mi; car La et Sib sont déjà un peu bas, et $F a$ et $S o l$ très élevés, ce qui rend le son criard; on s'en sert néanmoins encore quelquefois.
In military music the chords $\mathrm{A}$ and $\mathrm{B} b$ are only seldom useful; on the contrary all the other higher chords are used quite often. The best chords for the orchestra are: C, $\mathrm{D}, \mathrm{E} b$, and $\mathrm{E}$, because both $\mathrm{A}$ and $\mathrm{B} b$ are already a little low, and $\mathrm{F}$ and $\mathrm{G}$ are very high, although these produce shrill sounds, they are nevertheless sometimes still used. 
L'accord de la trompette en $U t$ est à

l'unisson avec le violon et la clarinette en

$U t$, et ainsi, d'une octave plus élevé que le

cor en $U t$; Exemple:

$1^{\text {re }}$ Trompette en Ut.

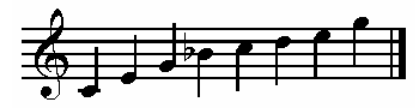

effet:

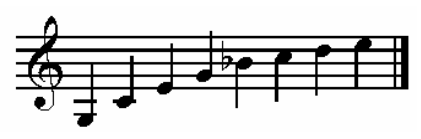

2. ${ }^{\mathrm{e}}$ Trompette en Ut.

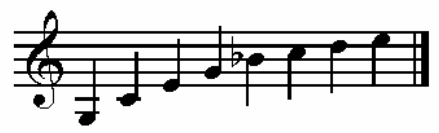

effet:

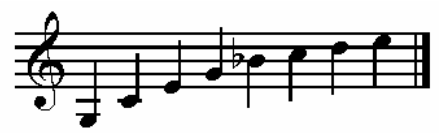

L'accord en Ré est d'un ton entier plus

élevé que le violon et ainsi d'une octave

plus élevé que le cor en Ré; Exemple:

1. ${ }^{\text {re }}$ Trompette en Ré.

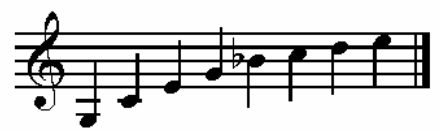

effet:
The chord of the trumpet in $\mathrm{C}$ is in unison with the violin and the clarinet in $\mathrm{C}$ and thus, of an octave higher than the horn in C; for example:

First trumpet in $\mathrm{C}$

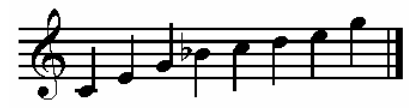

effect:

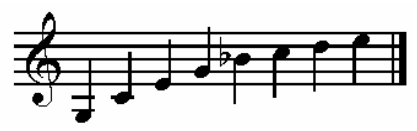

Second trumpet in C:

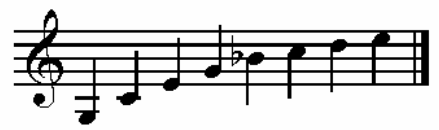

effect:

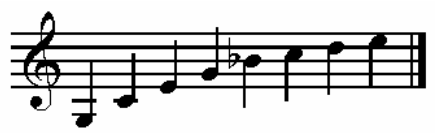

The chord in D is of a whole tone higher than the violin and thus an octave higher than the horn in D; for example:

First trumpet in D:

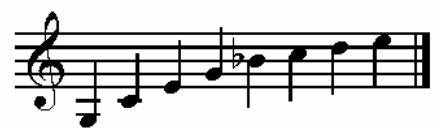

effect: 


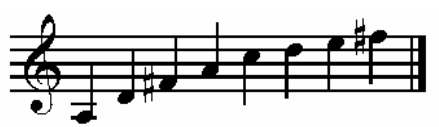

2. ${ }^{\mathrm{e}}$ Trompette en Ré.

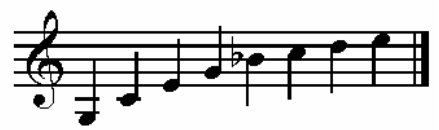

effet:

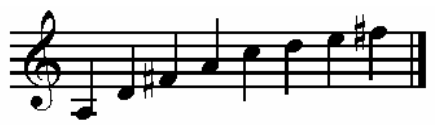

Dans les accords: $M i$ b $, M i, F a$ et $S o l$,

ordinairement on ne doit pas écrire plus

haut pour l'orchestre, que

parceque les sons plus élevés ne peuvent

pas s'attaquer d'une manière précise.

L'accord en $M i b$ est d'une tierce mineure

plus haut que le violon ou la clarinette en

$U t$, et, par conséquent, d'une octave plus

haut que le cor en $M i b$; Exemple:

1. ${ }^{\text {re }}$ Trompette en Mib.

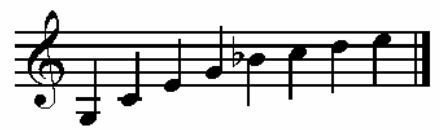

effet:

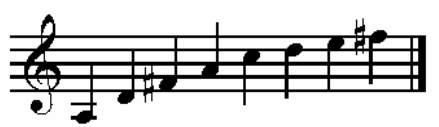

Second trumpet in D:

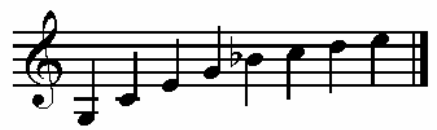

effect:

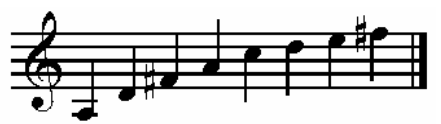

Ordinarily, one must not write higher

than in the orchestra in the

following chords: E b, E, F, and G. This

is because the higher sounds cannot be executed in a precise manner.

The chord in $\mathrm{E} b$ is a minor third higher than the violin or the clarinet in $\mathrm{C}$, and consequently an octave higher than the horn in $\mathrm{E} b$; for example:

First trumpet in $\mathrm{E} b$

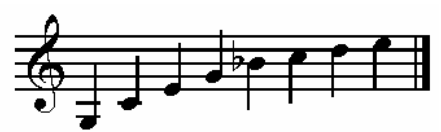

effect: 


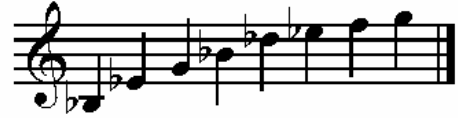

2. ${ }^{\mathrm{e}}$ Trompette en Mib.

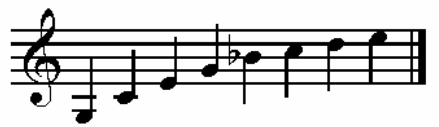

effet:

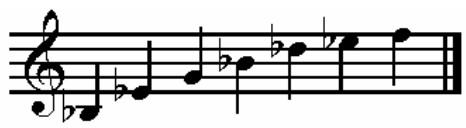

L'accord en $M i$ est d'une tierce majeure

plus élevé que le violon ou la clarinette en

$U t$, et ainsi, d'une octave plus élevé que le cor en $M i$; Exemple:

1. ${ }^{\text {re }}$ Trompette en Mi.

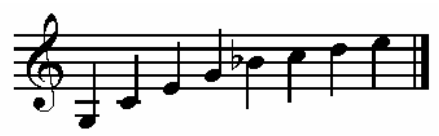

effet:

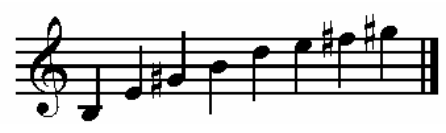

2. ${ }^{\mathrm{e}}$ Trompette en Mi.

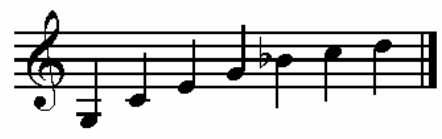

effet:

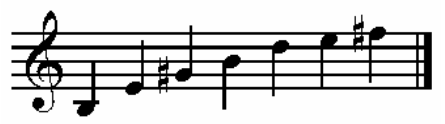

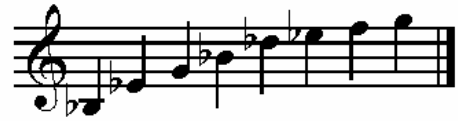

Second trumpet in $\mathrm{E} b$

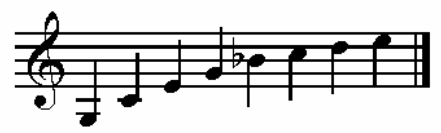

effect:

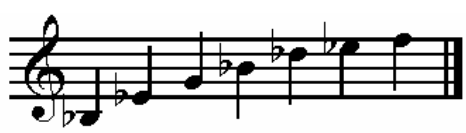

The chord in $\mathrm{E}$ is a major third higher than the violin or the clarinet in $\mathrm{C}$ and thus, an octave higher than the horn in E, for example:

First trumpet in E:

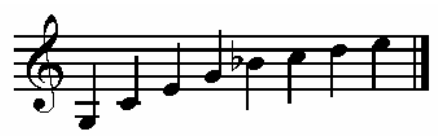

effect:

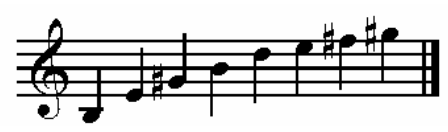

Second trumpet in E:

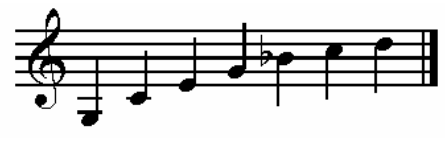

effect:

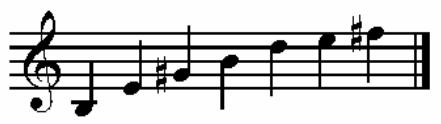


L'accord en $\mathrm{Fa}$ est d'une quarte juste plus The chord in $\mathrm{F}$ is a perfect fourth higher élevé que le violon ou la clarinette en $U t, \quad$ than the violin or the clarinet in $\mathrm{C}$ and et ainsi, d'une octave plus élevé que le cor thus, an octave higher than the horn in F: en $\mathrm{Fa}$ :

$1 .{ }^{\text {re }}$ Trompette en F.

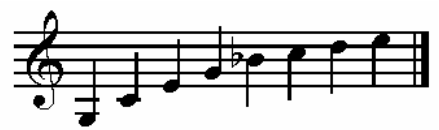

effet:

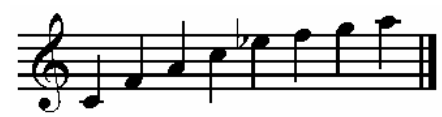

$2 .{ }^{\mathrm{e}}$ Trompette en F.

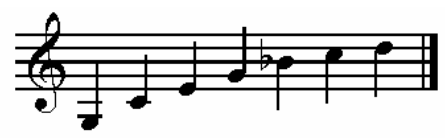

effet:

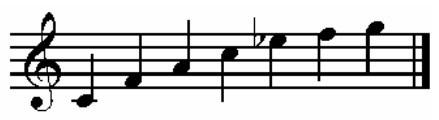

L'accord en Sol est d'une quinte parfaite

plus haut que le violon ou la clarinette en $U t$, ou d'une octave plus haut que le cor en Sol:

1.re Trompette en Sol.

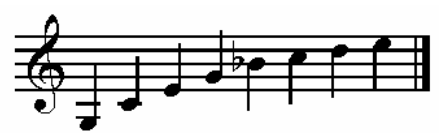

First trumpet in F

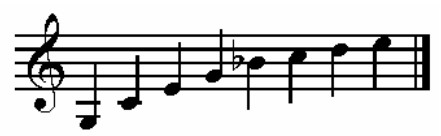

effect:

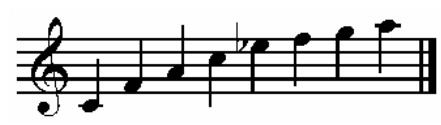

Second trumpet in F

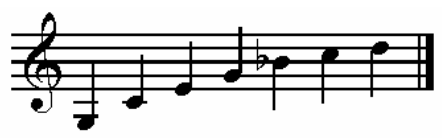

effect:

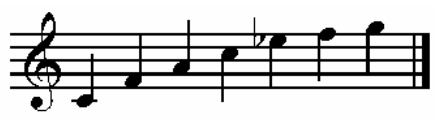

The chord in $\mathrm{G}$ is a perfect fifth higher than the violin or the clarinet in $\mathrm{C}$, or an octave higher than the horn in G:

First trumpet in $\mathrm{G}$

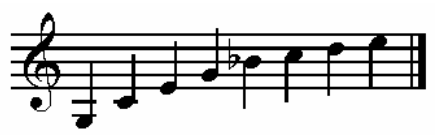


effet:

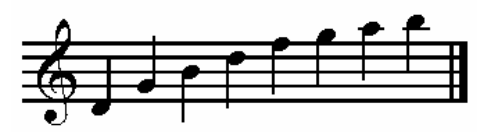

2.e Trompette en Sol

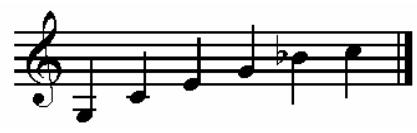

effet:

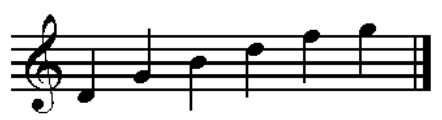

Ainsi qu'on le voit par les exemples

précédens, la première trompette n'atteint

jamais aux notes les plus hautes et la

seconde ne descend jamais aux plus

graves; quant aux notes élevées, on ne doit

s'en servir que très rarement, parcequ'elles

ont un son très aigu et qu'on les manque

quelquefois.

Comme la trompette a fort peu de tons on

est obligé d'employer beaucoup de corps

de rechange, pour produire les différens

$a c^{d s}$.

Ce qui a été dit à l'occasion du cor pour le saut de la septième et autres intervalles, se rapporte aussi à la trompette. effect:

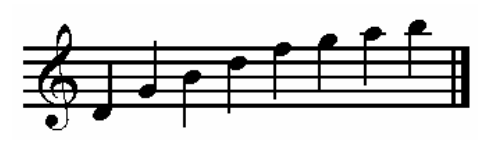

Second trumpet in G

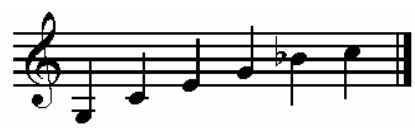

effect:

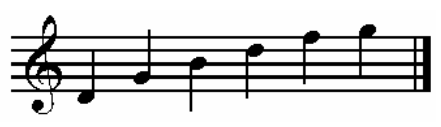

As one sees in the preceding examples,

the first trumpet never reaches the highest

notes, and the second never goes down to

the lowest; as for the high notes, one

should only use them very seldomly,

because they have a very high sound, and, because one misses them.

As the trumpet has very few notes, one is obliged to use many crooks in order to produce the different chords.

What was previously stated relative to the horn's jump of the seventh and other intervals also refers to the trumpet. 
Les notes piquées en doubles-croches, triples-croches [sic] ou autres sont d'une exécution facile; il faut néanmoins se garder de les employer trop souvent, parceque, dans l'orchestre, elles dégénèrent en un effet militaire et même commun.

Dans le peu de tons que possède la trompette, il arrive souvent que la première et la seconde jouent à l'unisson, ce qui ne fait pas mal, si toutefois la seconde peut bien attaquer les notes hautes; souvent, aussi, quoiqu'étant [sic] elles-mêmes des parties de discant elles suivent les mêmes progressions que les basses, ce qui produit encore un assez bon effet, pourvu qu'elles ne s'élèvent pas trop au-dessus des autres instrumens, ce qu'il faut éviter en général.

On ne doit pas écrire de trilles pour l'orchestre, bien qu'on puisse les exécuter depuis le jusqu'au excepté
The staccato notes in sixteenth-notes, triple-eighth notes or others are easy to play; nevertheless one must take care to not use them too often, because, in the orchestra, they degenerate into a military and even common effect.

With the few tones that the trumpet has, the first and the second often play in unison, which does not produce a bad effect, if however the second can tackle the high notes well; often, although the trumpets themselves are part of the of the discant, they follow the same progressions as the basses, which still produces a rather good effect, provided that they do not rise too much above the other instruments, which is necessary to avoid in general.

One should not write trills for the orchestra, although one can play them

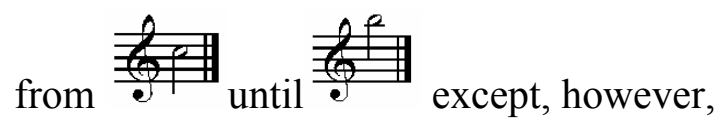


toutefois le ${ }_{\text {et le }}$ and sans the cela, manquent déjà de pureté; il faut donc purity; thus these two last notes should be éviter ces deux dernières notes autant que avoided as much as possible, either as possible, soit comme notes tenues, soit held notes, or in unisons. dans les unissons.

Tous les autres tons ont un son clair et perçant, ce qui fait qu'une seule note produit souvent un effet important.

On peut aussi, à partir de l'Ut de la 3 me $^{\text {me }}$ petite octave, jusqu'au Sol de la 3. ${ }^{\text {me }}$ petite octave, donner avec la langue une espèce de tremolo que l'on indique comme suit: Trompette en Mi b.

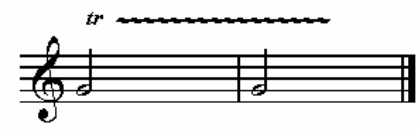

effet:

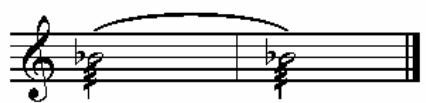

Trompette en $\mathrm{Fa}$

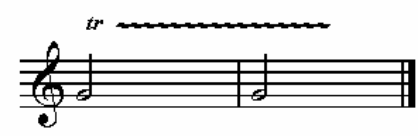

effet:
All the other tones have a clear and piercing sound, with the result that one note alone often produces a significant effect.

One can also, starting from $\mathrm{C}$ of the third small octave and up to $\mathrm{G}$ of the third small octave, use the tongue to produce a type of tremolo, which one indicates as follows:

Trumpet in $\mathrm{E} b$ :

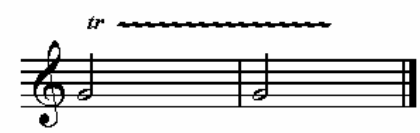

effect:

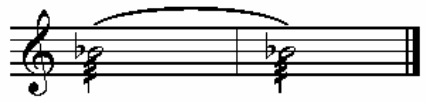

Trumpet in F:

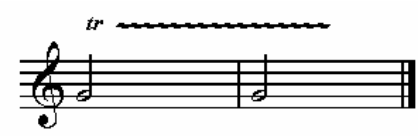




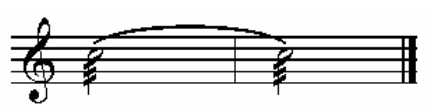

Ce tremolo peut se prolonger pendant

plusieurs mesures; cependant, on ne

l'emploie ordinairement que dans la

musique militaire où il fait souvent très

bon effet.

Ce qui a été dit pour le cor, à l'occasion

des tons majeurs et mineurs, se rapporte

également à la trompette, et les trompettes

doublent souvent les cors à l'octave, quand

on les emploie pour renforcer la masse de

l'orchestre. ${ }^{129}$

Il semble toujours aux jeunes

compositeurs, qu'avec le peu de tons de la

trompette on ne puisse tirer aucun parti de

cet instrument, mais si l'on ne prodigue

pas trop les modulations et si ou en use

avec réserve, on verra bientôt qu'il peut

très bien atteindre un résultat avantageux.

Nous avons des Méthodes pour la effect:

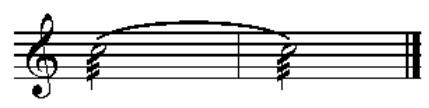

This tremolo can be prolonged for several

measures; however, one usually only uses

it in military music, where it often

produces a very good effect.

What was said for the horn with regard to the major and minor keys, also applies to the trumpet, and when they are used to reinforce the mass of the orchestra, the trumpets often double the horns at the octave.

To young composers, it always seems that with the trumpet's few keys, one hardly benefits from use of this instrument, but if one is not too lavish with the modulations or if one uses them with reserve, one will soon see that the trumpet can easily produce an advantageous result.

There are methods for the trumpet by 
trompette de Froehlich, Altenburg, Buhl, Froehlich, Altenburg, Buhl, Kling and

Kling et autres. ${ }^{130,131} \quad$ others.

\section{LE CORNET.}

Il y a plusieurs espèces de cornets. Le

cornet en $L a b$ qui est proprement une

trompette en $L a b$ alto, qu'on appelle

vulgairement cornet en $L a b$, parcequ'il a

la forme du cor et ne sert ordinairement

que dans la musique militaire et les

morceaux d'orchestre rapides. ${ }^{132}$

Il est d'une sixte plus élevé que le violon

ou la clarinette en $U t$, et d'une octave plus

élevé que le cor en $L a b .$.

Les tons dont on peut se servir sont les

suivans:

Cornet en La $b$ :

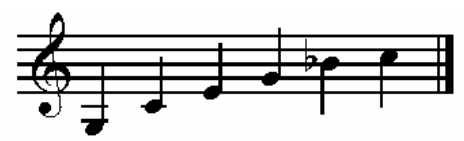

effet:

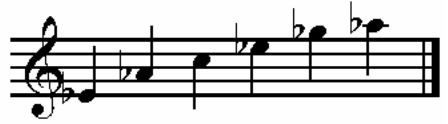

Les tons plus élevés sont d'une exécution très difficile.

\section{THE CORNET}

There are several species of cornet. The cornet in the $\mathrm{A} b$ which is properly a alto trumpet in $\mathrm{A} b$, that one vulgarly calls cornet in $\mathrm{A} b$, because it has the shape of the horn and is useful usually only in military music and the fast orchestral pieces.

It is a sixth higher than the violin or the clarinet in $C$ and an octave higher than the horn in $\mathrm{A} b$.

The tone which one can be useful oneself are the following:

Cornet in $\mathrm{A} b$ :

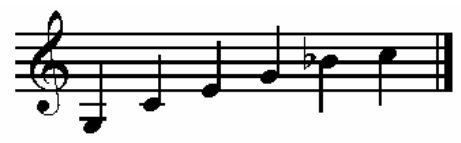

effect:

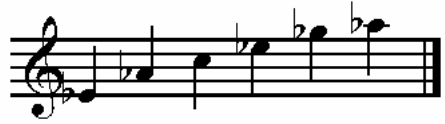

The higher tones are very difficult to play. 
Le cornet en $L a$ est d'une sixte plus élevé que le violon, et d'une octave plus élevé que le cor en $L a$ :

Cornet en La:

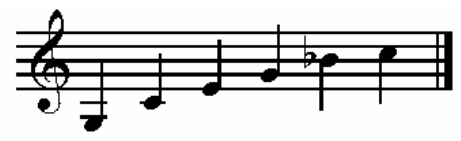

effet:

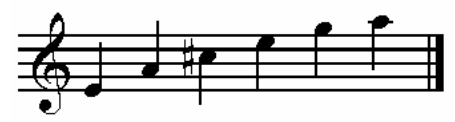

Le cornet in Sib est d'une septième mineure plus élevé que le violon, et d'une octave plus élevé que le cor en $\mathrm{Si}$ b alto: Cornet en Sib.

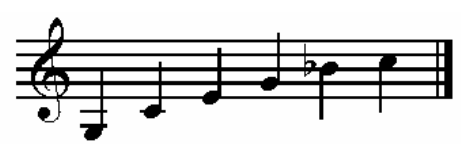

effet:

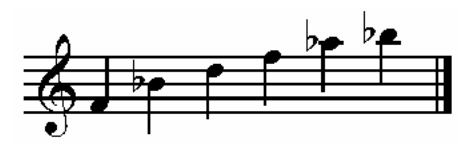

Le cornet en $U t$, (le plus élevé de tous) est d'une octave plus haut que le violon, et ainsi de deux octaves plus haut que le cor en $U t$ :
The cornet in A is sixth higher than the violin, and an octave higher than the cornet in A:

Cornet in A:

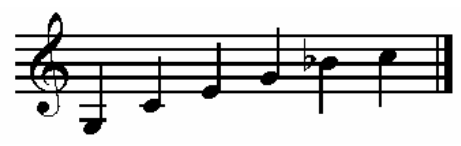

effect:

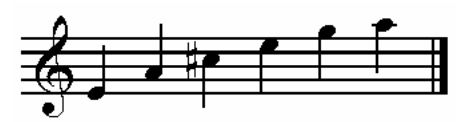

The cornet in $\mathrm{B} b$ is a minor seventh higher than the violin, and an octave higher than the alto cornet in $\mathrm{B} b$. Cornet in $\mathrm{B} b$ :

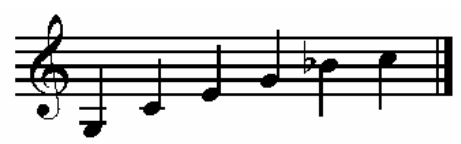

effect:

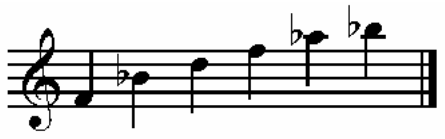

The cornet in C (highest of all) is of an octave higher than the violin, and thus of two octaves higher than the horn in C: 
Cornet en Ut.

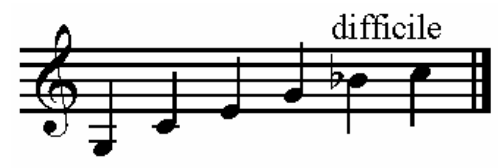

effet:

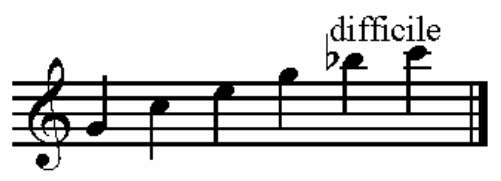

Il faut observer que le cornet ainsi que la

trompette a gagné beaucoup de tons au

moyen des pistons qu'on y a adapté et

qu'avec ces pistons nouvellement inventés,

on peut maintenant donner tous les sons

intermédiaires et produire de très bons

effets.

\section{LA TROMPETTE A PISTONS.}

La trompette à pistons se distingue de la

trompette ordinaire, en ce qu'elle peut

produire au moyen de deux pistons qui y

sont adaptés, tous les tons et demi-tons de

la gamme, d'une manière précise et juste;

son étendue entière est:

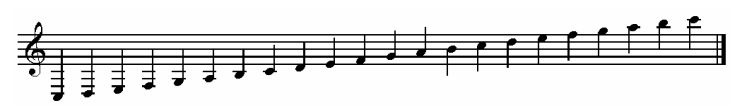

Chromatiquement.
Cornet in $\mathrm{C}$

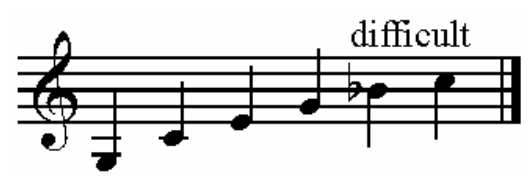

effect:

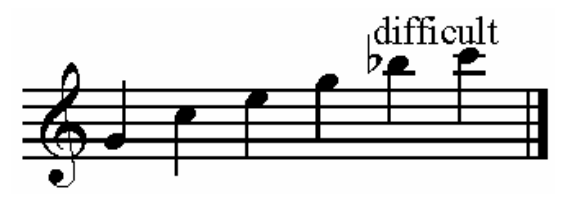

It should be observed that the cornet as

well as the trumpet gained many more

tones by means of the pistons that one

adapted there and that with these lately

invented pistons, one can now give all the

intermediate sounds and produce very

good effects.

VALVE TRUMPET.

The valve trumpet is distinguished from

the ordinary trumpetby what it can

produce by means of two pistons which

are adapted to it: all the tones and

semitones of the range which are

produced in a true and precise manner; its

entire range is:

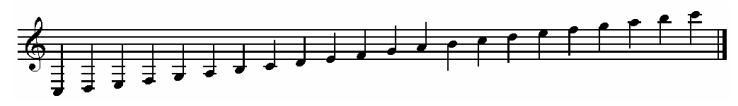




\section{Chromatically.}

Les tons les plus graves ne peuvent pas s'employer avec avantage, mais à partir du

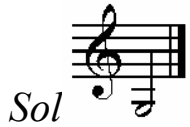
on peut monter par tous les tons

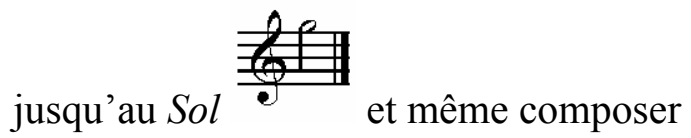

des passages rapides qui sont d'une exécution très facile.

On peut changer l'accord de la trompette à pistons aussi facilement que celui de la trompette ordinaire, au moyen de ses corps de rechange qui sont au nombre de six, savoir: Sol, Fa, Mi, Mi b, Ré, Ut; (on peut au besoin y adapter $S i$ grave.) Mais il n'est pas à beaucoup près si souvent nécessaire d'employer les corps de rechange, parcequ'à l'aide dés pistons, l'instrument produit tous les tons d'une manière nette. Du reste, il est généralement d'usage d'écrire la trompette à pistons en $U t$ comme la trompette ordinaire, en indiquant le corps de

The lowest tone cannot be used advantageously, but starting from

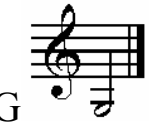
one can go up by all the tones

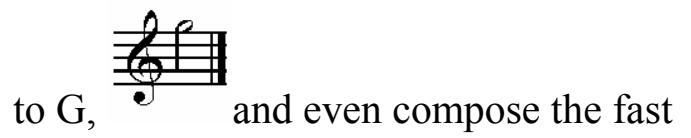
passages, which are very easy to execute.

One can as easily change the harmony of the valve trumpet as easily as that of the ordinary trumpet by means of crooks, of which there are six, namely: G, F, E, Eb, $\mathrm{D}, \mathrm{C}$ (if need be, one can affix low $\mathrm{B} b$ to it). But very often it is not necessary to use the crooks, because the instrument produces all the keys in a clear manner through the use of the pistons. In addition, it is generally useful to write the valve trumpet in $\mathrm{C}$, like the ordinary trumpet, by indicating the crook in the score and the individual parts. 
rechange à la partition et aux parties

détachées.

Pour ce qui concerne l'application dans

l'orchestre, les effets en sont les mêmes

que pour la trompette ordinaire; ce n'est

que depuis quelque tems qu'on a écrit pour

cette trompette des solos pleins d'effet qui

ne peuvent naturellement pas s'exécuter

sur l'ancienne; aussi est elle déjà presque

généralement adoptée dans les orchestres

où elle a de très belles parties dans les

nouveaux Opéras.

Ainsi qu'à la trompette on a adapté des

pistons au cornet qui joue aussi un grand

rôle dans la nouvelle musique.

LE CORNET A PISTONS.

Il y’a des cornets à pistons avec deux

pistons et d'autres avec trios; ces derniers

sont plus avantageux parcequ'on peut

donner une infinité de sons de deux

manières différentes, et qu'ainsi avec un

peu d'exercice on parvient a exécuter

beaucoup de passages difficiles avec
As for the valve trumpet's application in the orchestra, the effects are the same as that for the ordinary trumpet; it is only recently that solos of a full effect (which, naturally, cannot be played on the old trumpet) have been written for this trumpet; therefore has already been nearly universally adopted in the orchestras, where it has very beautiful parts in the new operas.

As with the trumpet, pistons have been affixed to the cornet, this instrument also plays a great role in new music.

\section{THE VALVE CORNET}

There are cornets with two pistons and others with three; the latter are more advantageous, because one can give an infinite amount of sounds in two different manners, and that thus with a little practice one is eventually able to play many difficult passages with precision 
justesse et précision. ${ }^{133}$

Le cornet à pistons est toujours en $U t$, comme le cornet ordinaire ou la trompette; il faut donc nécessairement indiquer chaque fois le corps de rechange. Il y en a huit, savoir: Sib, La, La b, Sol, Fa, Mi, $M i b$, et Ré qui est le plus bas.

Tous ces tons ne doivent pas s'employer indistinctement; les uns sont trop sourds, les autres trop éclatans [sic]; il faut donc choisir le corps de rechange propre à faire valoir le morceau qu'on veut exécuter, et pour cette raison il ne faut pas que le cornet à pistons ait le corps de rechange du ton dans lequel est écrit le morceau de musique; par exemple, si les violons jouent en Sol, on peut, au lieu de donner le corps de rechange Sol, prendre le corps de rechange $S i b$, et alors le cornet joue en $L a$ :

Violon.

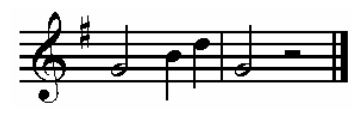

Cornet en Sib.

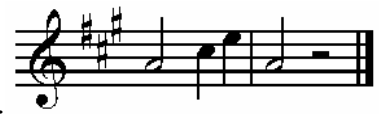

and accuracy.

The cornet is always in C, like the ordinary horn or the trumpet; thus, it is necessary to indicate the crook each time one is needed. There are eight crooks, namely: $\mathrm{B} b, \mathrm{~A}, \mathrm{~A} b, \mathrm{G}, \mathrm{F}, \mathrm{E}, \mathrm{E} b$, and $\mathrm{D}$, which is the lowest.

All these keys should not be used indiscriminately; some are too muted, while others are too brilliant; thus, one must choose the crook most appropriate to the piece one wishes to execute, and for this reason the cornet need not have a crook in the key in which the musical piece is written, for example: if the violins play in $\mathrm{G}$ one can, instead of using the $\mathrm{G}$ crook, use the $\mathrm{B} b$ crook, and then the cornet plays in A:

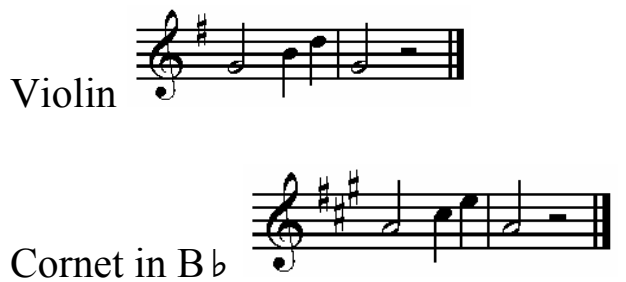

Or if the violin plays in $\mathrm{C}$ one can use the 
le corps de rechange $M i$, et le cornet joue alors en $L a$ :

\section{Violon.}

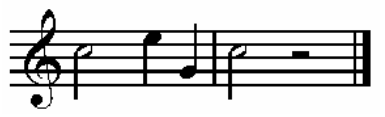

Cornet en Mib.

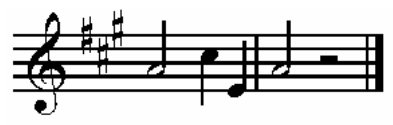

Ou si le violon joue en Sol, on peut

prendre le corps de rechange $L a$, et le cornet joue en $S i$ :

Violon.

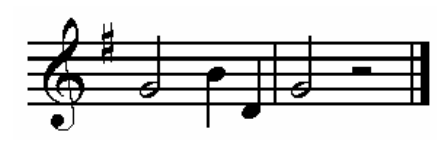

Cornet en La.

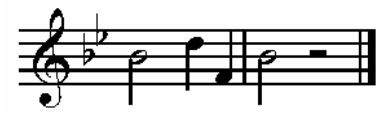

$\mathrm{Ou}[$ sic] si le violon joue en Ré, on peut

prendre le corps de rechange Sol, et le cornet jour en Sol.

Violon.

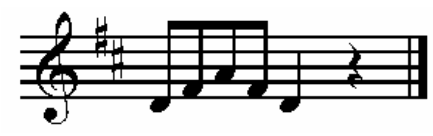

Cornet en Sol.

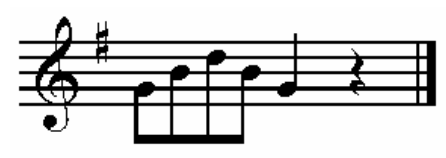

Il y a aussi beaucoup de compositeurs qui écrivent maintenant le cornet de la manière
$\mathrm{E} b$ crook, and the cornet then plays in A:

Violin

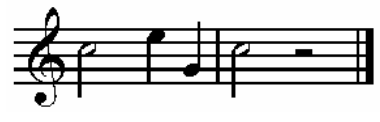

Cornet in $\mathrm{E} b$

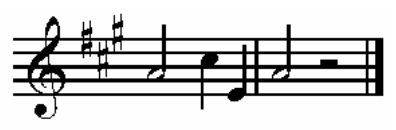

Or if the violin plays in $\mathrm{G}$ one can take the A crook and the cornet plays in $\mathrm{B} b$ :

Violin

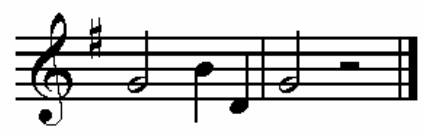

Cornet in $\mathrm{A}$

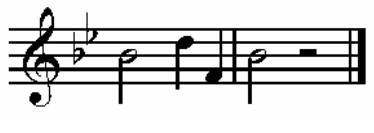

Or if the violin plays in $\mathrm{D}$, one can use the $\mathrm{G}$ crook, and the horn will play in $\mathrm{G}$.

Violin

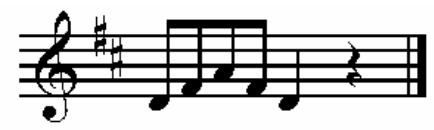

Cornet in $\mathrm{G}$

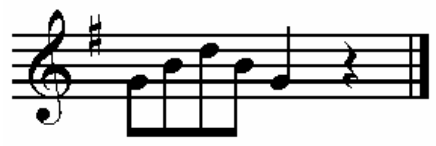

There are also many composers who, instead of writing the cornet as before, 
suivante, au lieu de l'écrire comme autrefois:

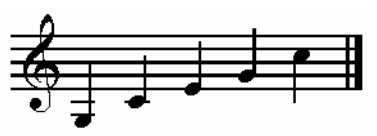

Ils écrivent:

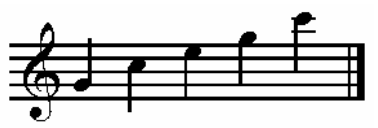

Et ainsi de suite toutes les notes une octave plus haut qu'autrefois, parceque, disent-ils, cette manière est plus facile et plus naturelle à lire. Du reste les deux manières sont bonnes.

L'étendue du cornet à deux pistons est:

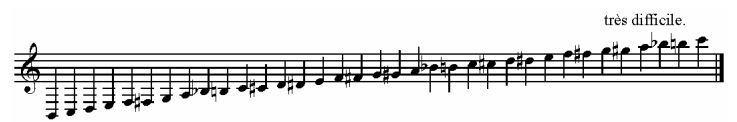

L'étendue du cornet à trois pistons est:

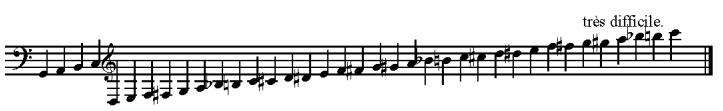

Mais pour cet instrument comme pour la trompette à pistons, il ne faut pas écrire

plus bas que

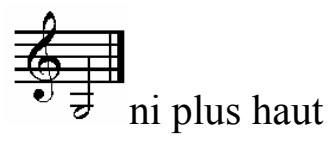

now write in the following manner:

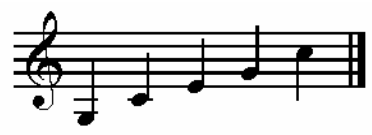

Written:

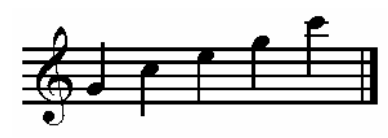

This continues with all the notes an octave higher than before, because, they say, this manner is easier and more natural to read. In any case, both of the methods are good.

The range of the two-piston cornet is:

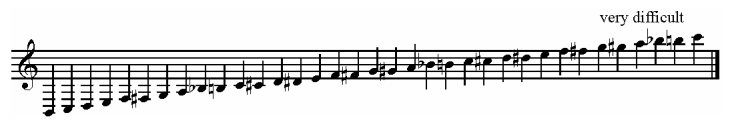

The range of the three-piston cornet is:

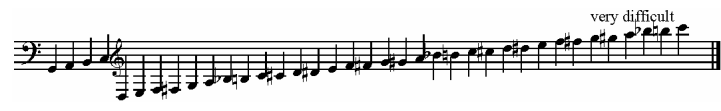

However, for this instrument as well as for the valve trumpet, one should not write lower than

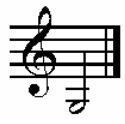
nor higher than 
que parceque presque tous les artistes peuvent jouer convenablement depuis ce Sol jusqu'a l'Ut ou au Mi, mais, pour donner d'une manière juste les sons plus hauts et plus graves, il faut être da d'une grande force.

Les meilleurs tons pour le solo sont: Lab, $L a$ et $S o l$, l'accord en $S i b$ est déjà un peu élevé et celui en $F a$ un peu bas; en général cet instrument ne sert que pour les solos. Le coup de langue s'y donne aussi bien que sur la trompette. Quand on veut employer le cornet dans les tutti, il ne faut pas $1 .^{\circ}$ le noter trop haut; 2 . $^{\circ}$ il faut bien prendre garde aux progressions, parceque, comme il est très élevé, son timbre fort et clair pourrait produire un mauvais effet.

On emploie très souvent deux cornets à pistons qui marchent alors ensemble par tierces ou sixtes; quelquefois aussi dans des tons différens et chacun d'eux a son

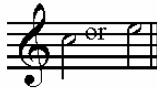

, because nearly all artists can play suitably from this $G$ to $C$ or even $E$ but, to producethe higher and lower sounds with true and precise effect, they must use great force.

The best keys for solos are: A b, A, and $\mathrm{G}$, the chord in $\mathrm{B} b$ is already a bit high, and the chord in F a bit low; in general this instrument is only useful for solos. Use of tonguing works as well for the valve cornet as for the trumpet.

When one wants to use the horn in the tutti, first: it must not be notated too high; second: one must exercise caution when using the progressions, because, as the cornet is very high, its strong and clear timbre could create an undesirable effect. One very often uses two valve cornets, which then play together by thirds or sixths and occasionally in different keys as well; each of them has its own 
chant particulier.

Nous avons des Méthodes pour le cornet à

pistons de Bassieres-Faber, Guttermann,

C. Schuberz et autres. ${ }^{134}$

\section{LA TROMPETTE A CLEFS}

Il y en a de plusieurs espèces, savoir; en distinctive style.

We have methods for the valve cornet by

Bassieres-Faber, Guttermann, C Schuberz and others.

\section{THE KEYED TRUMPET}

There are several types of them, namely:

Si b, en $U t$, en Mib haut et bas, en Ré haut, in B b, C, high and low E b, high D, in

en $L a b$; il serait bon d'en avoir aussi en $L a \quad A b$; it would also be good to have some

pour l'orchestre.

Les plus usitées sont les trompettes à clefs en $\mathrm{Sib}$ et en $U t$.

Il est à remarquer que le ton de cet instrument a beaucoup perdu par les clefs du timbre clair et forts de la trompette ordinaire; il a du rapport avec celui de l'ophicléide, aussi pourrait-on envisager la trompette à clefs comme soprano de l'ophicléide.

Son étendue est:

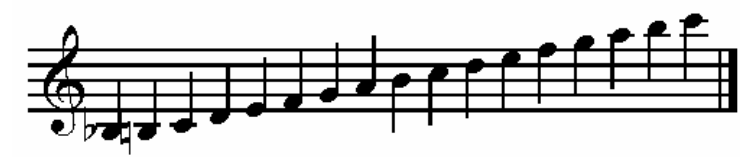

Cette étendue comprend tous les tons et demi-tons; seulement, il ne faut pas keyed trumpets in A for the orchestra.

The most commonly used keyed trumpets are in $\mathrm{B} b$ and $\mathrm{C}$.

It is to be noted that, by virtue of its keys, this instrument's tone may be found lacking in comparison with the clear and strong timbre of the ordinary trumpet.

Moreover, the keyed trumpet it is related to the ophicleide therefore, one could consider it the ophicleide's soprano.

Its range is:

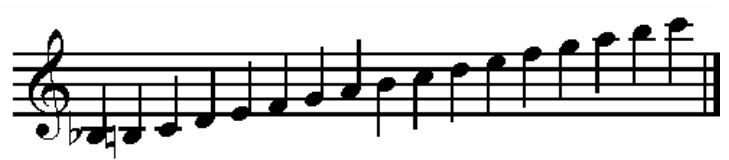

This range includes all the tones and semitones; except that one should not go 
descendre plus bas que
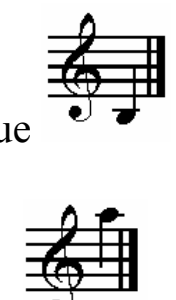

monter plus haut que pour être sûr que tout sera joué d'une manière pure et juste.

La trompette à clefs en $S i$ b, s'écrit toujours comme la trompette à clefs en $U t$, mais l'effet des tons est d'une note plus bas; exemple:

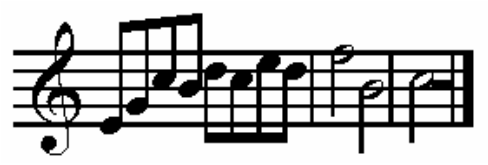

effet:

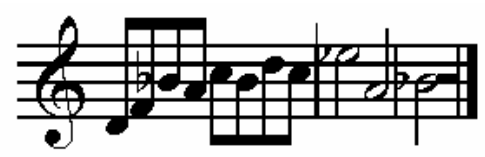

De même les autres accords se traitent

comme pour les trompettes; il ne faut

pourtant pas croire que cet instrument a

des corps de rechange comme les autres

trompettes, parcequ'ici chaque accord

exige un instrument à part; par exemple: la trompette à clefs en $M i b$ est un instrument tout autre que la trompette à clefs en $S i$ b
The keyed trumpet in $\mathrm{B} b$ is always

written like the keyed trumpet in $\mathrm{C}$, but these notes effect is that of a lower note;

for example:

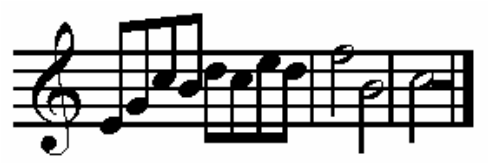

effect:

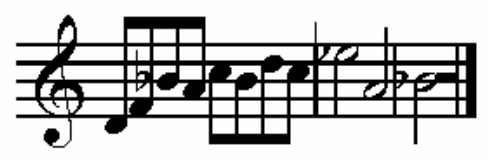

Similarly, the other chords are treated as they are for the trumpets; however, this instrument does not have crooks like the other trumpets, on the keyed trumpet, each chord requires an separate instrument, for example: the keyed trumpet in $\mathrm{E} b$ is completely different from the keyed trumpet in $\mathrm{B}$ bor in $\mathrm{C}$. 
ou celle en $U t$.

Il n'est pas nécessaire de changer souvent It is not necessary to change instruments

d'instrument dans le cours d'un morceau; often in the course of a piece; this is why

c'est pourquoi on calcule d'avance les one calculates the modulations in

modulations, et ainsi, pour un morceau qui advance; thus, for a piece which has

a beaucoup de bémols on prend la many flats one uses the trumpet in $\mathrm{B} b$,

trompette en $\mathrm{Si}$, pour un morceau avec for a piece with sharps, the trumpet in $\mathrm{C}$

dièzes, la trompette en $U t$, (parceque celle (because a trumpet in A has not yet been

en $L a$ n'est pas encore introduite. $)^{135} \quad$ introduced).

Cet instrument s'emploie tant dans la This instrument is used as often in

musique militaire que dans l'orchestre; military music as it is in the orchestra;

toutefois, il en a été un peu écarté par la however, it was pushed aside somewhat

trompette à pistons qui a conservé son by the valve trumpet, which preserved its

véritable ton de trompette et n'a rien perdu true trumpet tone, and did not lose any of

de sa force ou de sa clarté. $\quad$ its force or clearness.

Comme il y a deux trompettes à clefs en As there are two keyed trumpets in $\mathrm{E}$, it

$M i$, il faut observer que l'une est d'une should be observed that one is a minor

tierce mineure plus élevée que la trompette third higher than the keyed trumpet in $\mathrm{C}$,

à clefs en $U t$; l'autre d'une sixte plus basse and the other is a sixth lower than this

que cette même trompette en $U t$; cette same trumpet in $\mathrm{C}$, which is also called a

dernière se nomme aussi. Demi-lune à crescent because of its shape. It has had

cause de sa forme. On a dû la recourber to be bent slightly, because it had been

légèrement parceque sans cela elle eut été much too long and too inconvenient to 
beaucoup trop longue et trop incommode à hold; it is, as it were, in tune with the alto tenir; elle est pour ainsi dire au diapason ophicleide; one plays it like the other de l'ophicléide alto; on la joue comme les keyed trumpets and the range is the same: autres trompettes à clefs et l'étendue en est la même:

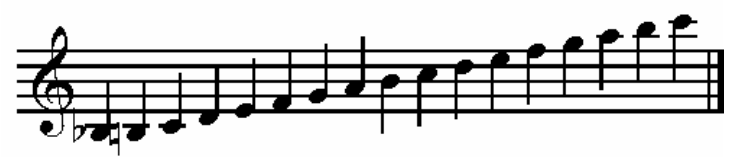

Chromatically

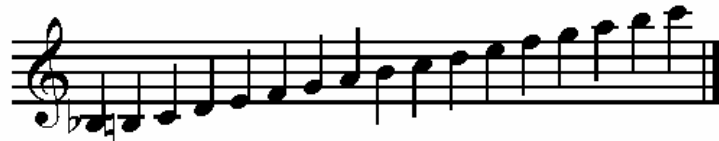

\section{Chromatiquement.}

Mais l'effet en est d'une sixte plus bas:

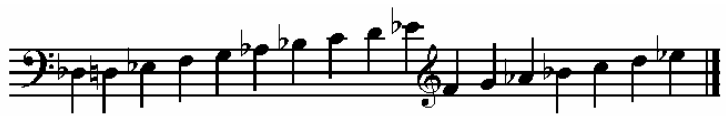

But the effect is a sixth lower:

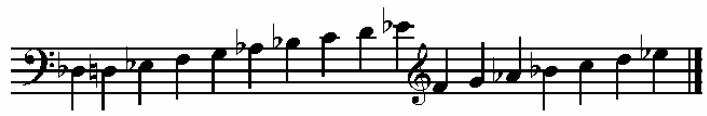

L'accord en Ré est d'un ton plus élevé que celui en $U t$, et ainsi d'un demi-ton plus bas que l'accord en Mib haut. L'accord en $L a b$ est d'une tierce majeure plus bas que celui en $U t$ ou d'un ton plus bas que celui

The chord in $\mathrm{D}$ is a tone higher than the one in $\mathrm{C}$, and thus a semitone lower than the chord in high $\mathrm{E} b$. The chord in $\mathrm{A} b$ is a major third lower than that in $\mathrm{C}$, or a tone lower than that in $\mathrm{B} b$. en $\mathrm{Si}$.

On s'est encore servi pendant quelque For some time, the four-keyed cornets tems de cornets qui portaient quatre clefs were still sometimes used; one treated et qu'on traitait comme les autres cornets them like the other cornets in different dans différens tons, leur étendue était: keys, and their range was:

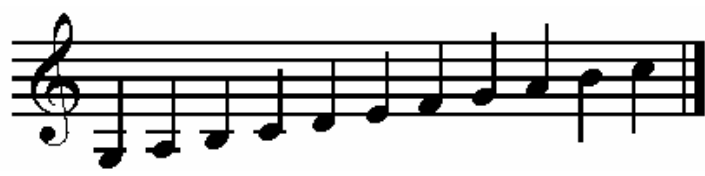

Chromatiquement.

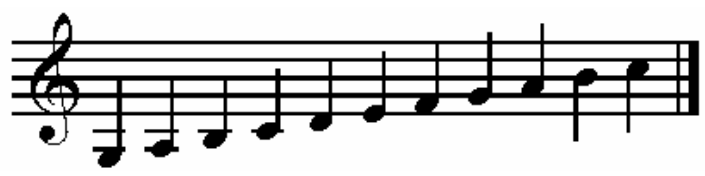

Chromatically. 
Mais ces cornets ne restèrent pas longtems en usage à cause des cornets à pistons dont le ton est beaucoup plus brillant.

Les militaires employaient aussi une trompette à clefs nommée clairon; elle ne portait que trois ou quatre clefs et était par cela même très imparfait, aussi, ne pouvait-on y jouer que des morceaux toutà-fait simples et faciles.

Nous avons une Méthode de clairon de

Schiltz.

\section{LE COR DE SIGNAL.}

Le cor de signal est un instrument dans le genre de la trompette; il a la forme d'une demi-lune, mais sans clefs.

On ne peut y donner que cinq tons,

savoir:

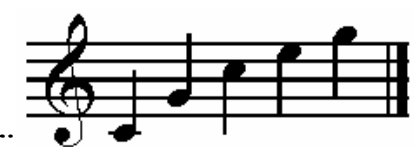

au moyen

desquels on parvient encore cependant à

composer de petites mélodies.

Il s'emploie surtout en Allemagne dans

l'infanterie, pour donner le signal des évolutions.
But these cornets did not remain long in use, because of the valve cornets whose tone is much more brilliant.

Soldiers used also a keyed trumpet called a bugle; it carried only three or four keys, and even those were not at all perfect; therefore, one could only play the most completely simple and easy pieces on it.

There is a method for the bugle by

Schiltz.

\section{COILED NATURAL HORN}

The signal horn is an instrument in the genre of the trumpet; it has the shape of a half-moon, but without keys.

One can play only five tones, namely:

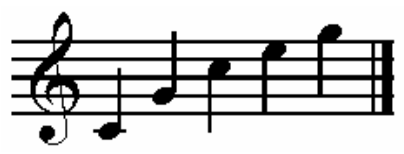

with the means

of which one still however manages to compose of small melodies.

It is used especially in Germany in the infantry, to give the signal of the changes. 
Les accords ordinaires dans lesquels on fait cet instrument, sont: $S i b$ et $M i b$; il y en a pourtant aussi quelques autres mais qui sont plus rares.

Cor de signal en Sib.

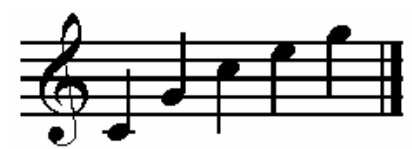

effet:

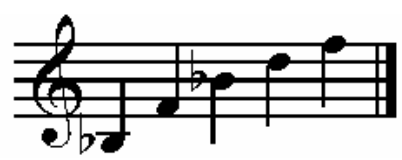

The ordinary chords, in which one plays this instrument, are: $\mathrm{B} b$ and $\mathrm{E} b$ there are of them however also some others but which are rarer.

Signal horn in $\mathrm{B} b$ :

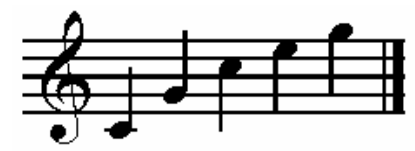

effect:

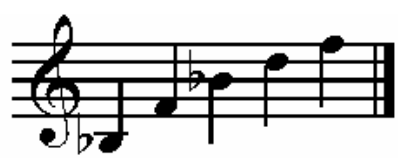

L'accord est à l'unisson avec le cor en Sib haut, l'effet est donc d'un ton plus bas que les notes:

Cor de signal en Mi b.

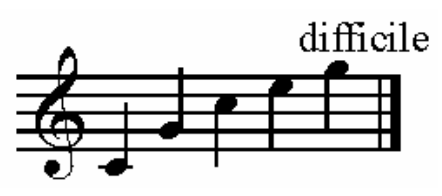

effet:

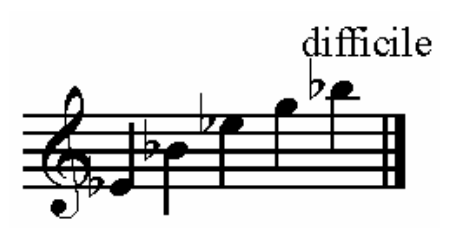

Cet accord est à l'unisson avec la trompette en $M i b$, et d'une octave plus
The chord is in unison with the horn in

high $\mathrm{B} b$, the effect is thus of a tone lower than the notes:

Signal horn in $\mathrm{E} b$ :

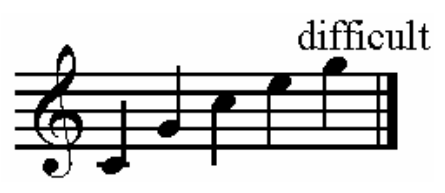

effect:

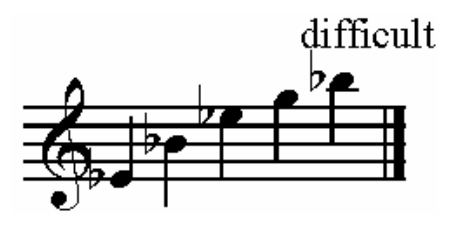

This chord is in unison with the trumpet in $\mathrm{E} b$, and of an octave higher than the 
haut que le cor en $M i b$; les tons sont donc

d'une tierce mineure plus haut que les

notes écrites.

Cet instrument sert aussi quelquefois dans

la musique militaire pour de petits solos

qui font très bon effet, parcequ'on peut $\mathrm{y}$

donner le coup de langue comme sur tous

les instrumens de cuivre. Exemple:

Cor de signal en $\mathrm{Si}$.

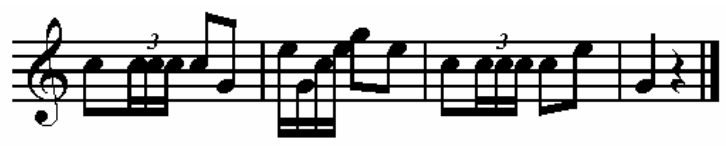

\section{LE TROMBONNE.}

Il y a trois espèces de trombonnes: $1 .^{\circ}$ le

trombonne alto, $2 .^{\circ}$ le trombonne ténore

$[$ sic $], 3 .^{\circ}$ le trombonne basse.

Le trombonne alto est l'instrument le plus

élevé de ce genre; son étendue commence au $M i$ de la petite octave et va jusqu'au Ré,

$M i b$ et même $F a$ de la, $3 .^{\text {me }}$ petite octave.

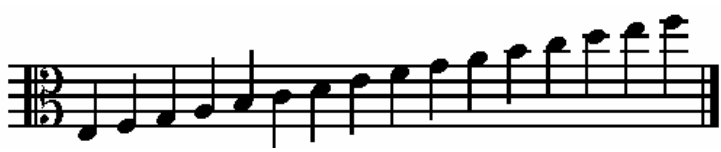

Mais comme les notes les plus hautes et les plus basses sont douteuses, on ne doit horn in $\mathrm{E} b$; the sounded tones are thus a

minor third higher than the written notes.

This instrument is also useful sometimes

in military music for small solos which

make very good effect, because one can

give to it the tonguing as on all the copper

instruments. For example:

Signal horn in $\mathrm{B} b$.

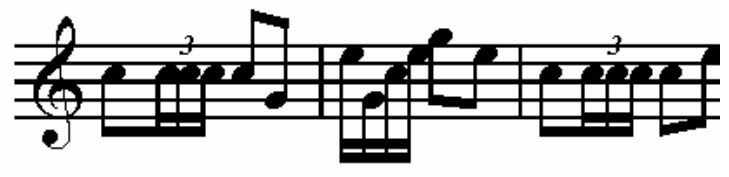

\section{THE TROMBONE}

There are three types of trombones: first, the alto trombone; second, the tenor trombone; and third, the bass trombone.

The alto trombone is the highest

instrument of this type; its range starts

with E of the small octave and goes to D,

$\mathrm{E} b$ and even $\mathrm{F}$ of the third small octave.

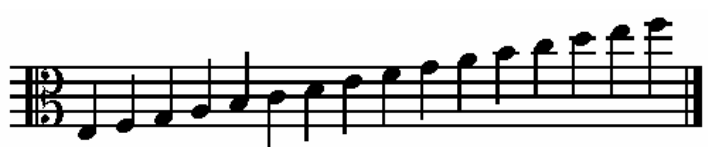

But as most of the highest and lowest notes are of dubious effect, one must 
jamais écrire plus haut que

plus bas que never write higher than nor

lower than

alto est à l'unisson avec la viole; toutefois, trombone is in unison with the viola;

on fait bien de s'en tenir aux tons du

médium parceque ceux du haut sont

perçants et, comme nous l'avons déjà dit, difficiles à intonner.

Cet instrument s'écrit ordinairement sur la

clef d'Ut, 3. ${ }^{\text {me }}$ ligne, et comprend dans son

étendue tous les tons et demi-tons dont

l'effet est le même que celui indiqué par

les notes.

On peut aussi y jouer dans tous les tons;

seulement, ceux avec beaucoup de dièzés

ou de bémols sont plus difficiles; des

figures rapides ne conviennent pas au

trombonne alto, mais plutôt des sons

prolongés ou coupés. Au moyen du coup

de langue on peut produire plusieurs fois

de suite le même ton, absolument comme

avec le cor et la trompette.

Dans la musique militaire on emploie however, it is best to stick to the middle

tones because those at the top are piercing

and, as we have already said, difficult to

tune.

This instrument is usually written on the

C clef third line, and includes all the

tones and semitones in its range. The

sounding pitche is the same as the written

pitch.

It can be played in all the keys; except

that those with many sharps or flats are

more difficult; fast figures are not

appropriate for the alto trombone, but

rather sustained or stopped sounds work

well. By tonguing, one can play the same

tone several times, just as one can with

the horn and the trumpet.

This instrument is seldom used in 
rarement cet instrument, et quand on s'en sert, il est toujours réuni aux trombonnes

ténor et basse; des solos en forme de

chorals pour les trois espèces font un effet admirable.

Les sforzando surtout se dessinent bien sur le trombonne, mais ordinairement on n'écrit pas de trilles pour cet instrument, bien que des artistes puissent en exécuter quelquefois dans des concerts.

Les intervalles sautans $[$ sic $]$ ou se suivant dans un ordre qui n'est pas naturel, ne doivent pas s'employer, parceque le trombonne a la faculté de bien donner tous les tons, ce qui n'a pas lieu pour le cor ou la trompette, comme nous l'avons observé plus haut.

Très souvent le trombonne alto marche avec la basse pour la renforcer.

Le trombonne ténor, ou buccin.

Son étendue commence au Mi de la grande octave et va jusqu'au $S o l$ et même $S i$ b de la $2{ }^{\text {me }}$ petite octave; mais chez lui, comme military music, and when it is used, it is always played together with the tenor and bass trombones. Solos in the form of chorals for all three of these instruments produce an admirable effect.

The sforzando are especially good on the trombone, but trills are not usually written for this instrument, although artists may sometimes play a few in concerts.

The skipping intervals, or thosee which follow an unnatural order, should not be used, because the trombone is faculty to play all the tones keys well, which is not true for the horn or the trumpet, as we have observed earlier.

Very often, the alto trombone plays with the bass to reinforce it. The tenor trombone or buccina. Its range starts with $\mathrm{E}$ of the great octave and goes up to $\mathrm{G}$ or even $\mathrm{B} b$ of the second small octave; but here, as with 
chez le trombonne alto, les tons les plus hauts et les plus braves sont douteux, et ne doivent s'employer qu'avec précaution, parcequ'il faut un grand talent pour les attaquer avec justesse et pureté.

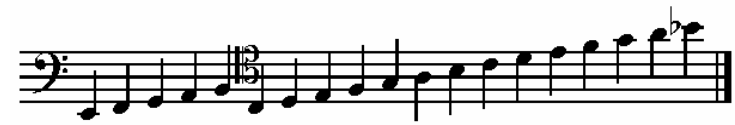

Cet instrument s'écrit ordinairement sur la clef d' $U t, 4 .{ }^{\text {me }}$ ligne, et l'effet des tons est le même que celui indiqué par les notes; cependant, on l'écrit aussi souvent sur la clef de $\mathrm{Fa}, 4 .{ }^{\mathrm{me}}$ ligne, surtout dans les partitions nouvelles ou quelquefois l'espace est très restreint, et où les trois trombonnes réunis ne donnant que des accords, sont notés l'un au dessus de l'autre sur une même portée.

D'autres fois on note ensemble sur une seule portée les trombonnes, alto et ténor qui s'écrivent alors tous deux sur la clef $\mathrm{d}^{\prime} U t, 4{ }^{\mathrm{me}}$ ligne, et le trombonne basse une portée au dessous sur la clef de $F a$.

Cet instrument comprend dans son étendue the alto trombone, the highest and truest tones are of dubious effect, and must be used judiciously, since great talent is needed to tackle them with accuracy and purity.

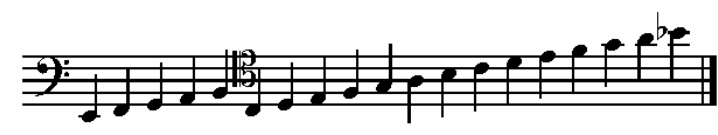

This instrument is usually written on the fourth line of the $\mathrm{C}$ clef, and the sounding pitch is the same as the written pitch; however, it is also often written on the bass clef, especially in new scores where space is sometimes very restricted, and when three trombones playing that play only chords are notated one on top of the other on the same staff.

Other times, one may notatethe alto and tenor trombones on a single staff; these would be written on the $\mathrm{C}$ clef, fourth line, and the bass trombone a staff lower, on the bass clef.

All the tones and semitones are included 
tous les tons et demi-tons, ce qui fait qu'on in this instrument's range, which means

peut y jouer dans tous les tons.

Quant au coup de langue, trilles, $\&^{\mathrm{a}}$ ce qui

a été dit à ce sujet pour le trombonne alto

s’applique également ici.

Les deux trombonnes alto et ténor font un

effet superbe, si on les emploie autant que

possible dans leur médium, parceque les

tons peuvent toujours s'en attaquer avec

franchise et pureté.

Le trombonne ténor est quelquefois seul

dans l'orchestre ou avec un des deux

autres, mais le plus souvent avec tous les

deux on même tems.

S'il n'y a pas de trombonne basse, le

trombonne ténor tient la partie la plus

grave et marche presque toujours avec la

contrebasse ou le violoncelle. ${ }^{136}$

\section{LE TROMBONNE BASSE}

Son étendue commence à l'Ut de la grande octave et va jusqu'au $M i, F a$ et même $S o l$ de la $2 .{ }^{\text {me }}$ petite

octave. that it can be played in all the keys.

As for tonguing, trills, and the like, what

was previously stated about the alto

trombone also applies here.

If they are used in their middle register as

much as possible, both the alto and tenor

trombone create a superb effect, because

the tones can be always attacked with

frankness and purity.

The tenor trombone is sometimes played

alone in the orchestra, or with one of the

two others, but they are most often played

in tutti.

If there is no bass trombone, the tenor

trombone plays the lowest part, and

almost always plays with the double bass

or the violoncello.

BASS TROMBONE

Its range starts with $\mathrm{C}$ of the great octave and goes up to E, F, or even G of the second small octave. 


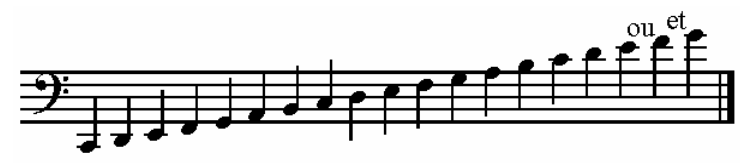

On l'écrit toujours sur la clef de $F a, 4{ }^{\text {me }}$ ligne.

Il comprend dans son étendue tous les tons et demi-tons et l'effet en est le même que celui représenté par les notes.

Relativement au coup de langue, trilles $\&^{\mathrm{a}}$ tout ce qui a été dit pour les trombonnes alto et ténor, se rapporte également ici.

On doit éviter autant que possible les passages compliqués, mais les notes tenues ou coupées produisent le meilleur effet.

Si on écrit des passages pour cors, trompettes et trombonnes, on doit s'efforcer de donner suz trombonnes des intervalles qui ne peuvent pas s'exécuter sur la trompette ou le cor; mais, en même tems, il faut avoir égard aux accords produits par les trombonnes pour qu'aucun intervalle absolument nécessaire ne fasse défaut, par exemple la tierce dans l'accord parfait, ce qui ferait toujours mauvais effet

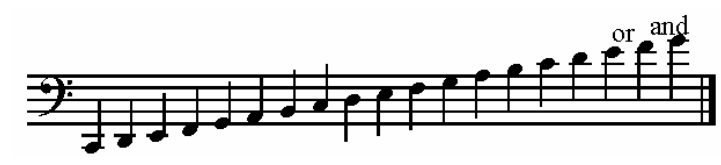

It is always written on the bass clef.

All the tones and semitones are included in its range, and the sounding pitch is the same as the written pitch.

All that was true for the alto and tenor trombones relative to tonguing, trills, and the like is also applicable here.

Complicated passages must be avoided as much as possible, but held or cut notes produce the best effect.

If one writes passages for horns, trumpets and trombones, one must endeavor to give the trombones intervals which cannot be played on the trumpet or the horn; but, at the same time, it is necessary to pay attention to the chords produced by the trombones so that no absolutely necessary interval makes an error, for example: the third in the triad, which would always make a bad impression 
quand bien même le cor ou la trompette donnerait cette tierce. Cela tient à la différence de timbre entre le trombonne et le cor ou la trompette.

En général il faut se garder d'écrire des accords imparfaits pour les trombonnes, surtout s'il n'y a ni cors ni trompettes, parcequ'alors l'effet en est encore plus détestable; il faut donc, si les trombonnes jouent seuls ou comme accompagnement à peu d'autres instrumens, choisir avec soin les intervalles qu'ils doivent donner et même plusieurs mesures à l'avance, afin qu'il ne manque jamais un intervalle nécessaire.

Dans de pareilles occasions on est quelquefois forcé de recourir à de petits sauts, mais il faut tâcher de les placer dans la partie du médium.

Il n'est pas bien de faire commencer les when played by the trombones; when played by the horn or the trumpet, however, this third would have a good effect; this is due to the difference in timbre between the trombone and the horn or trumpet.

In general, one must be careful not to write imperfect chords for the trombones, especially if there are neither horns nor trumpets, because then the effect in is even more detestable. Thus, one must, if the trombones only play as accompaniment to a few other instruments, carefully choose the intervals the trombones must play and to calculate them several measures in advance, so that they never miss a necessary interval. On such occasions, one is sometimes forced to resort to the use of small jumps, one must try to place these jumps in the middle part of the piece.

It is not good to have the trombones 
trombonnes tout seuls sans

accompagnement d'autres instrumens, parceque les trombonnes ne possèdent pas de moyen assez sûr pour déterminer le ton, et qu'alors de tels passages sont souvent faux; mais, si un morceau de musique a déjà précédé, ou si d'autres instrumens jouent en même tems, on peut avoir la certitude de donner des accords justes et on peut très bien aussi leur écrire des solos, dont, ceux en forme de chorals, sont du plus grand effet.

Nous avons des Méthodes pour le trombonne de Braun, Froehlich, Cornette, Berr et Dieppo et autres. ${ }^{137}$

\section{LE TROMBONNE A PISTONS}

Cet instrument remplace la coulisse du trombonne ordinaire par trois pistons au moyen desquels on peut non seulement donner tous les tons comme sur le trombonne, mais encore avec plus de rapidité et de justesse. Cet instrument étant encore peu répandu, il sera begin alone, without the accompaniment

of other instruments, because the

trombones do not have the ability to

determine the tone, and such passages

often ring false; but, if a piece of music

has already begun, or if other instruments

play at the same time, they can certainly

play chords precisely; they can also have solos written for them (chorales have the greatest effect).

There are methods for the trombone by

Braun, Froehlich, Cornette, Berr and

Dieppo, and others.

\section{THE VALVE TROMBONE}

This instrument replaces the slide of the

ordinary trombone with three pistons.

The pistons can not only play all the

notes that the trombone does, but it does

so with more speed and accuracy. Since

this instrument is still not very well-

known, musicians will in all likelihood be 
vraisemblablement agréable aux artistes de pleased to find the follwing table of the trouver ici le tableau des différens degrés different pitches produced by the pistons, produits par les pistons, et la gamme as well as the chromatic scale. chromatique. $^{138}$

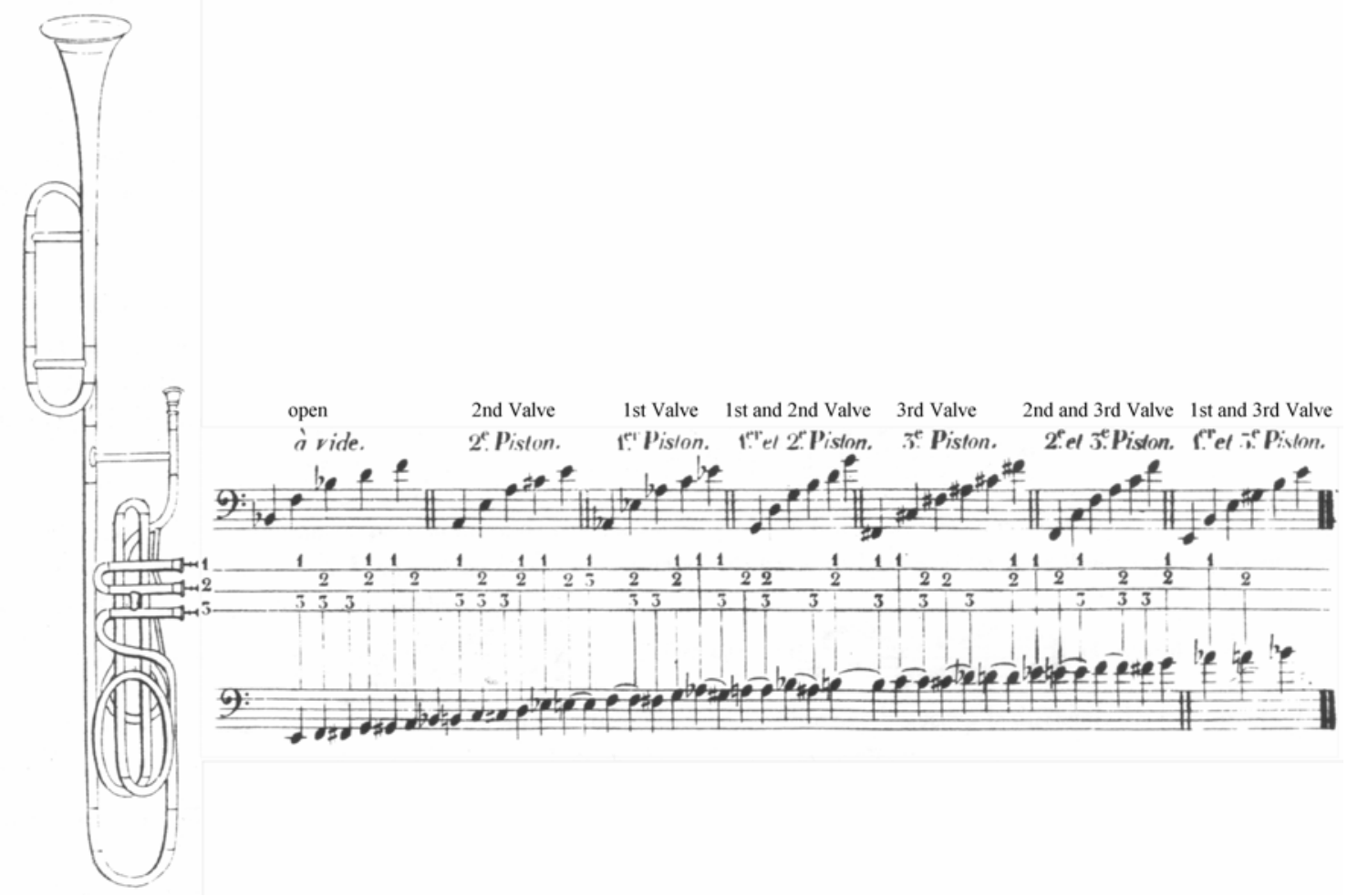

\section{L'OPHICLEIDE.}

Il y a différentes espèces de cet instrument

dont le ton plein de force est beaucoup

plus puissant que celui du trombonne et qui s'emploie maintenant dans l'orchestre comme dans la musique militaire.

1. ${ }^{\circ}$ Ophicléide alto en Mi $b$.

Cet instrument le plus petit de l'espèce a
THE OPHICLEIDE

There are different types of this

instrument whose forcefull tone is much more powerful than the trombone's; it is now used in orchestral and military music.

1. Alto Ophicléide in $E b$.

The smallest instrument of this type has 
l'étendue suivante:

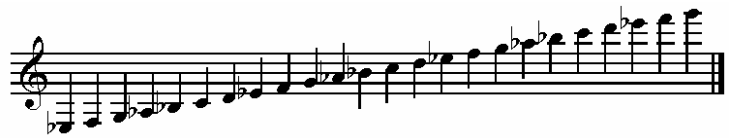

Mais on n'emploie ni les tons les

plus hauts ni les plus graves, parcequ'on

n'est jamais sûr de les attaquer avec

facilité et justesse.

L'étendue praticable est:

tout au plus

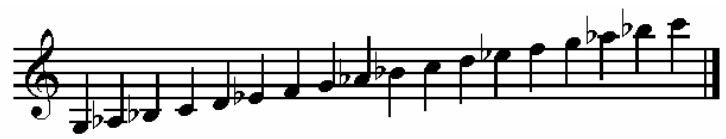

Il s'écrit sur la clef de Sol, 2. ${ }^{\mathrm{me}}$ ligne, quoique proprement on dût [sic] l'écrire sur la clef d'Ut, $3 .^{\text {me }}$ ligne.

Cet instrument est naturellement en Mib, et ses tons sont à l'unisson du trombonne alto; comme il donne avec justesse tous les tons et demi-tons, on peut l'employer dans tous les tons majeurs ou mineurs, en écrivant à la clef les dièzes ou bémols exigés par le morceau.

Jusqu'à présent, on n'a employé cet the following range:

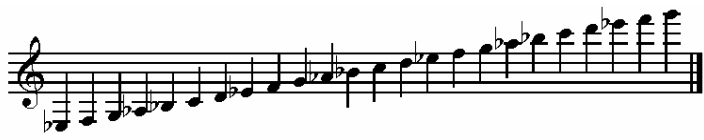

But neither the highest nor the lowest tones are used, because one is never sure of one's ability to play them with facility and accuracy.

The practicable range is:

\section{at most}

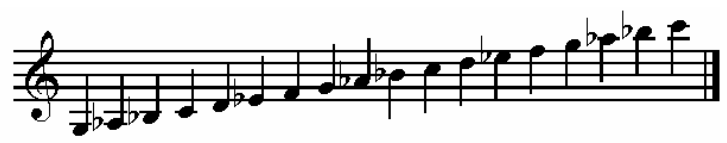

It is written on the treble clef, although strictly speaking, it was to be written on the $\mathrm{C}$ clef, third line.

This instrument is naturally in $\mathrm{E} b$, and its tones are in unison with the alto trombone; because it plays all the tones and semitones with accuracy, it can be used in all the major or minor keys, by writing the sharps or flat required by the piece in the key signature.

Until now, this ophicleide was only used 
ophicléide que dans la musique militaire, et de fait, il ne produisant pas bon effet dans l'orchestre, à cause de son timbre criard et perçant; mais dans la musique militaire, il double souvent le chant et le fortifie beaucoup. On lui donne aussi parfois des solos, parcequ'au moyen de ses clefs il peut exécuter tous les passages avec pureté et vitesse.

2. ${ }^{\circ}$ Ophicléide alto en Fa. Il a la même étendue que l'ophicléide alto en Mib, seulement, il est d'un ton plus haut que ce dernier.

L'étendue qu'on emploie d'ordinaire est: tout au plus

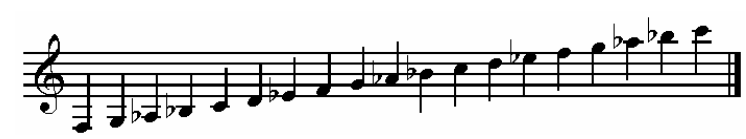

Chromatiquement.

Ce genre d'ophicléide est plus rare que l'ophicléide alto en Mi b.

3. ${ }^{\circ}$ Ophicléide basse en Ut (basse d'harmonie).

Les tons de cet instrument sont à l'unisson in military music, and in fact, it does not produce a good effect in the orchestra due to its garish and piercing timbre; but in military music, it often doubles the voices and in so doing, adds great strength to the sound. It is also sometimes given solos, since through the use of its keys; it can play all passages with purity and speed.

\section{Alto Ophicleide in F.}

Although it is one key higher than the ophicleide in E, both instruments have the same range.

The range usually used is:

at most

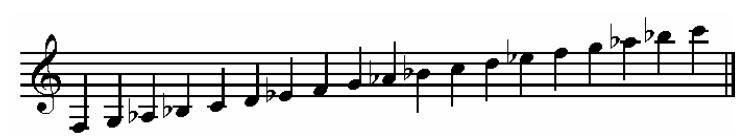

Chromatically.

This kind of ophicleide is rarer than the alto ophicleide in $\mathrm{E} b$

3. Bass Ophicléide in $\mathrm{C}$ (bass of the harmony).

This instrument's notes are in unison with 
du basson, et son étendue va du Sib de la contre octave jusqu'à l’Ut de la $3 .{ }^{\text {me }}$ petite octave.

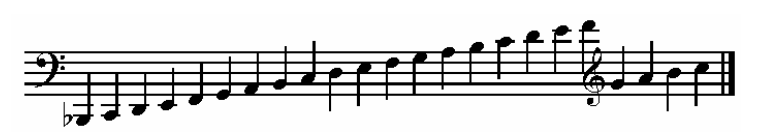

Chromatiquement.

On peut jouer sur cet instrument dans tous

les tons en plaçant à la clef les dièzés ou

les bémols exigés par le mode majeur ou

mineur; mais les tons les plus graves ne

servent que pour des notes tenues,

parceque, dans des passages rapides, elles

ne feraient pas d'effet; on rejette

également les notes les plus hautes, mais

l'étendue comprise entre le Ré de la

grande octave et le La de la $2 .^{\text {me }}$ petite

octave peut s'employer en toute sûreté.

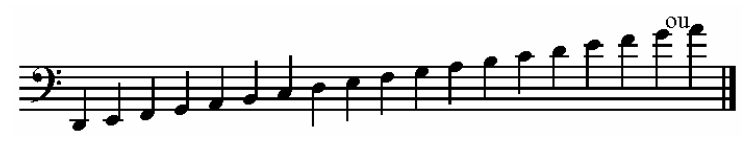

On se sert de cet instrument pour la basse

de l'harmonie, ce qui lui a fait donner

aussi ce nom.

4. ${ }^{\circ}$ Ophicléide basse en Sib. Il a la même the bassoon, and its range goes from $\mathrm{B} b$

of the contra-octave to $\mathrm{C}$ of the third

small

octave.

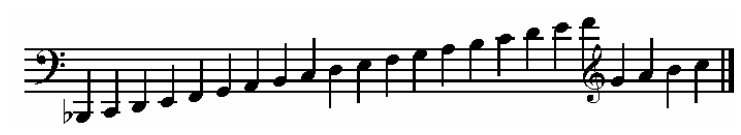

Chromatically.

By placing the sharps and flats required by the minor or major mode on the clef, one can play any key on this instrument, but the lowest notesa are only used for the held notes, because, in fast passages, they would not produce any effect; one also rejects the highest notes as well, but the range between $\mathrm{D}$ of the great octave and $\mathrm{A}$ of the second small octave can be used with confidence.

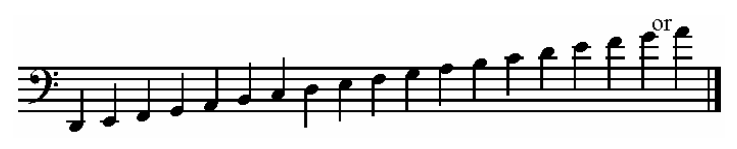

One uses this instrument for the bass of the harmony, from whence it got its name.

4. Bass Ophicleide in B b. 
étendue que l'ophicléide basse en Ut, mais

il est juste d'un ton plus bas que ce

dernier. Les notes suivantes, par exemple:
Although the Bass Ophicleide in $\mathrm{B} b$ is one note lower than the ophicleide in C, both instruments have the same range.

The following notes, for example:

Ophicléide en Si .

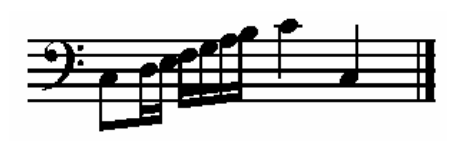

font l'effet de:

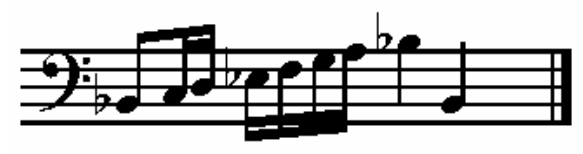

et ainsi

de suite.
Ophicleide in B $b$

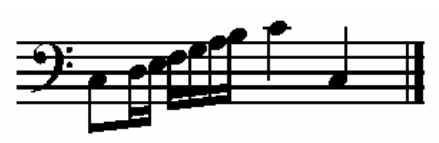

sounding:

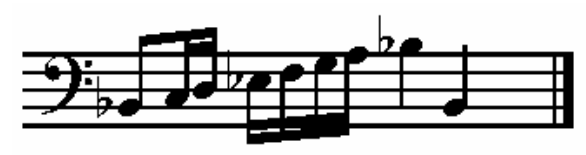

and so

on.

This instrument is often employed in flat keys; because it is less difficult, the artist can play in a key with two fewer flats than that of the Ophicleide in C; for example:

Ophicleide in C.

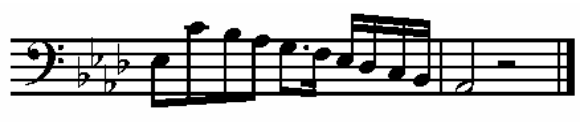

Ophicleide in B $b$.

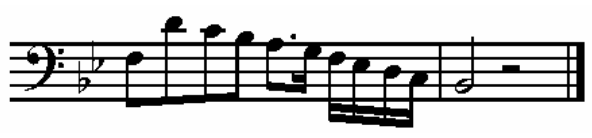


L'ophicléide en Sib se rencontre dans

presque toutes les musiques militaires, en

France, parceque la plupart des morceaux

de musique y sont bémolisés.

Cet instrument étant d'un ton plus bas que

l'ophicléide en Ut, peut donner le contre

Mais aussi d'un autre côte il a un ton de

moins dans le haut.

En général on devrait se servir de cet

instrument lorsqu'on emploie la clarinette

en Si b, surtout de nos jours où on lui fait

faire dans l'orchestre presque tous les

passages de violoncelle ou de contrebasse.

Nous avons une Méthode complète

d'ophicléide alto et basse de Cornette.

5. ${ }^{\circ}$ Ophicléide monstre en Fa.

Cet instrument, vraisemblablement connu

en Allemagne sous le nom de Bombardon

(à cause de la force de ses tons,) et que

d'autres appellent aussi Corno Basso

Chromatico, mais qui porte en France le

nom d'Ophicléide monstre en Fa, était

The ophicleide in $\mathrm{B} b$ is used in almost all military music in France because most the pieces of music are flatted there.

As this is in a lower key than the ophicleide in $\mathrm{C}$, it can produce the contraA b.

But on the other hand, the ophicleide in $\mathrm{B} b$ has one less note in the top range.

In general one should use this instrument when one uses the clarinet in $\mathrm{B} b$, especially nowadays when it is used in almost all the violoncello or double bass passages of the orchestra.

There is a complete method for the alto and bass ophicleide by Cornette.

5. Massive Ophicleide in F.

This instrument, actually known called a Bombardon in Germany (because of the force of its tone) and that is also sometimes called a Corno Basso Chromatico, but which in France called a "Monster Ophicleide in F", was formerly 
muni jadis de 10 ou 12 clefs auxquelles on a substitué trois pistons: c'est-à-dire qu'on a adapté à l'instrument trois tubes qui s'ouvrent et se ferment par des pistons.

Son étendue commence au Fa de la contre octave et va jusqu'au Sib de la $2 .{ }^{\text {me }}$ petite octave; on peut dans son étendue produire avec justesse tous les tons et demi-tons.

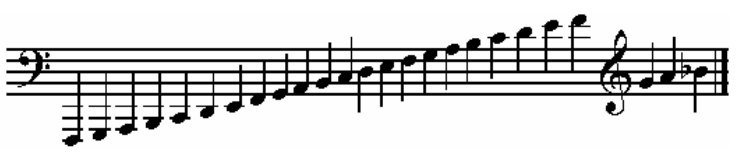

Son timbre a encore beaucoup plus de force que celui de l'ophicléide ordinaire; c'est de tous les instrumens de cuivre celui qui a le plus de puissance dans les tons, et en même tems le plus étendu.

Les tons les plus graves ne peuvent s'employer que pour des notes tenues et par cela même sont peu usitées, mais en général on peut exécuter tous les passages avec justesse et rapidité, aussi cet instrument est-il déjà adopté dans beaucoup de musiques militaires en provided with 10 or 12 keys which were replaced with three pistons: that is to say that three tubes which are opened and closed by pistons were affixed to the instrument.

Its range begins at $\mathrm{F}$ of the contra octave and goes to $\mathrm{B} b$ of the second small octave; all of the tones and semitones in its range can be produced with accuracy.

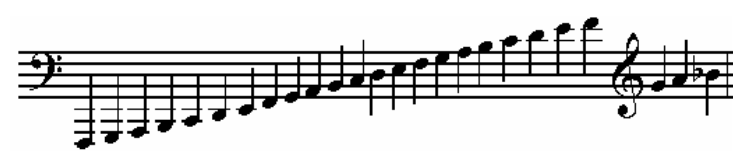

It has a much more forceful timbre than the ordinary ophicleide; it has the most powerful sound of all the copper instruments and at the same time the most range.

The lowest tones can be used only for held notes and are not used often, but in general one can play all the passages with accuracy and speed; this instrument has already been adopted in many military pieces in France. One can consider it the necessary bass voice for military music; it 
France; on peut le considérer comme la contrebasse nécessaire de la musique militaire; il est encore très bien placé dans la musique d'harmonie, c'est une basse parfaite dont on a toujours manqué jusqu'à présent.

Pour cet instrument comme pour l'ophicléide en Ut on se sert de la clef de $\mathrm{Fa} 4{ }^{\mathrm{me}}$ ligne et il faut avoir soin d'écrire à la clef les dièzes ou bémols exigés par le morceau de musique.

On a fait cet instrument sous deux formes différentes que je donne ici avec la gamme chromatique, pour mieux faire sentir les avantages qu'il présente, parcequ'il n'est pas encore généralement connu. ${ }^{140}$ is also very well placed in the music of harmony, and is a perfect bass that had been missing until now.

This instrument uses the bass clef, as does the ophicleide in $\mathrm{C}$ and one must be sure to write the sharps or flats required by the piece of music in the key signature. The massive ophicleide is made in two different shapes, which I give here along with their chromatic range, to better demonstrate its advantages, because this instrument is not yet generally wellknown. 

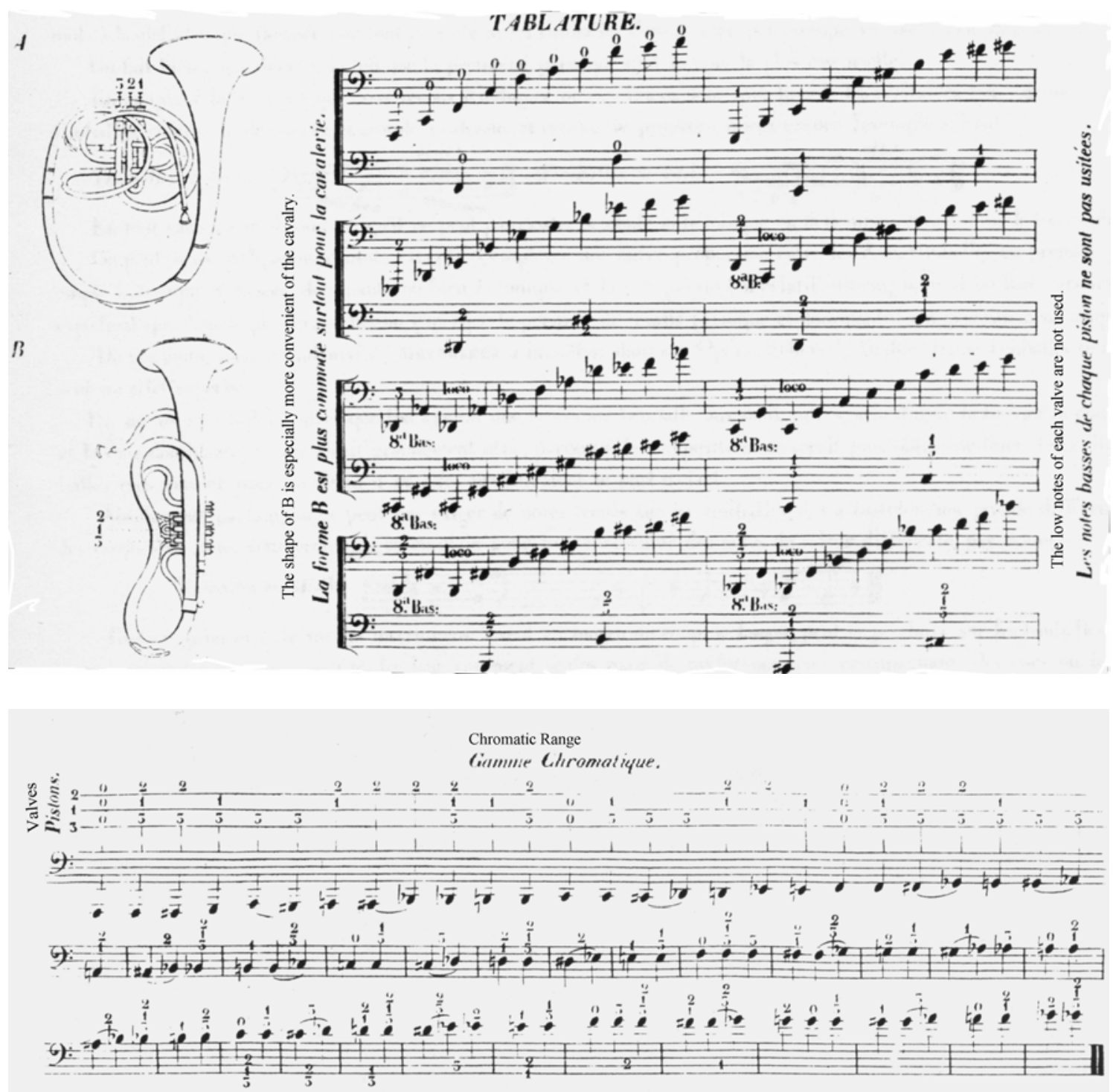

\section{L'APOLLO-LYRA.}

Cet instrument (qui n'est qu'un

perfectionnement du Psalmmelodicon de

Weinrich) a quelque ressemblance dans les

tons avec le violon, la clarinette, le

hautbois, le basson et le cor.

\section{THE APPOLONIAN LYRE}

This instrument (which is merely an improvement on Weinrich's

Psalmmelodicon) has some resemblance in tone to the violin, the clarinet, the oboe, the bassoon and the horn. 
Son étendue va du Fa de la grande octave jusqu'au Fa de la $4 .{ }^{\text {me }}$ petite octave par tons et demi-tons. On peut y jouer des morceaux à quatre et même jusqu'à six parties; il a la forme d'une lyre (d'où lui vient son nom), et porte quarante-deux clefs. Les sons de cor, surtout, sont très agréables et imitatifs; ils se produisent au moyen d'une certaine préparation, sans être joués et font l'effet d'un écho.

Le ton d'Ut majeur est le plus favorable à cet instrument, et les accords pris dans ce ton, résonnent d'une manière très énergique.

Quant à 1'harmonie, dans les tons: Ut, Sol, Ré, La, et Mi majeur, il ne contient que les quatre accords suivans; 1'accord parfait de la tonique, l'accord parfait de la sousdominante, l'accord de quarte sixte sur la dominante et l'accord de septième sur la dominante, puis encore l'accord parfait, ce qui forme la cadence ordinaire.
Its range goes from $\mathrm{F}$ of the great octave to $\mathrm{F}$ of the fourth small octave by tones and semitones. One can play pieces with four and even up to six parts; it has the shape of a lyre (hence its name), and bears forty-two notes. The horn sounds, especially, are very pleasant and imitative; they are produced by means of a certain preparation, without being played....... and create an echo effect. The key of $\mathrm{C}$ major is the most suitable for this instrument, and the chords produced in this key resound in a very energetic manner.

As for harmony, in the keys: C, G, D, A, and $\mathrm{E}$ major, it contains only the four following chords: the triad of the tonic, the triad of the sub-dominant, the six-four chord of the dominant and the chord of seventh of the dominant, and also the triad, which forms the ordinary cadence.

Dans les autres tons $\mathrm{Si} b, \mathrm{Mi} b, \mathrm{La} b$, et Ut In the other keys B b, E b, A b , and C 
mineur, il ne contient la plupart du tems que l'accord parfait, et l'accord de la dominante.

Nous ne pouvons donner ici la construction de cet instrument, parceque son auteur qui est toujours occupé à le perfectionner, n'en a encore rien publié.

\section{LA GUIMBARDE.}

Cet instrument consiste en un petit fer à cheval traversé d'une tige métallique aussi recourbée. On place l'instrument entre les dents et on met cette tige ou anche en vibration avec un doigt; la guimbarde sert ordinairement de jouet aux enfans [sic], cependant on trouve quelques artistes qui peuvent y exécuter des morceaux d'une certaine longueur et même dans différens tons; dans ce dernier cas, on est obligé de changer rapidement d'instrument. minor, for the majority of the time, it contains only the triad and the dominant chord.

We cannot treat the construction of this instrument in this report, because its author-who is always occupied with its improvement-has not published anything yet.

THE JAW-HARP

This instrument consists of a small horseshoe, crossed by a bent metal rod. One places the instrument between the teeth and one uses a finger to cause the rod to vibrate; although the jaw-harp is usually used as children's toy, there are some artists who can play pieces of certain length and even in different keys; in this last case, one is obliged to change instruments quickly. 
CHAPITRE V Instrumens à percussion.

L'étendue des timballes [sic] est comprise entre le Fa de la grande octave et le Fa de la petite octave:

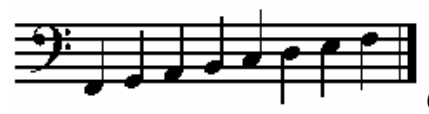

Chromatiquement.

Il y en a ordinairement deux dans

l'orchestre dont chacune donne un ton

différent; par le changement de l'accord on

obtient le ton de chaque morceau de

musique; la première timballe $[s i c]$ donne

la tonique, et la seconde, la dominante; il

n'y a presque jamais d'exception à cette

règle.

Il y a deux manières de les noter.

1. ${ }^{o}$ Beaucoup de compositeurs écrivent

toujours dans la partition les notes Ut et

Sol, et indiquent au commencement du

morceau le ton dans lequel on doit accorder

les timballes; par exemple:

Timballes en $\mathrm{Si} b-\mathrm{Fa}$

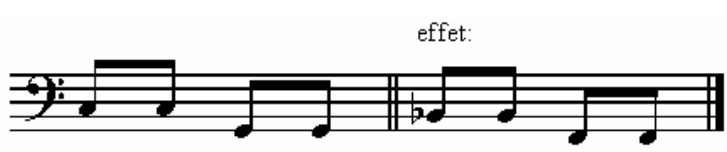

CHAPTER V. Percussion instruments

The range of the timpani lies between $\mathrm{F}$ of the great octave and F of the small octave:

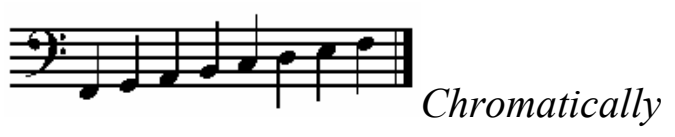

There are usually two of them in the orchestra, each of which produces a different key; by changing the chord, one obtains the key for each piece of music; the first timpani plays the tonic, and the second, the dominant; there is almost never exception to this rule.

There are two manners of notating them:

1. Many composers always write the notes $\mathrm{C}$ and $\mathrm{G}$ in the score, and indicate the key in which the timpani must be tuned at the beginning of the piece, for example:

Timpani in $\mathrm{B} b-\mathrm{F}$

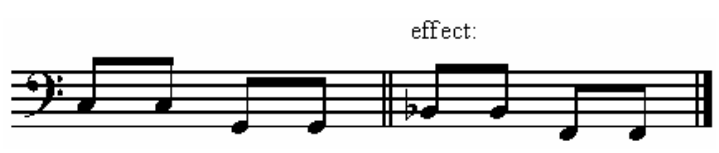


Timballes en Ut-Sol

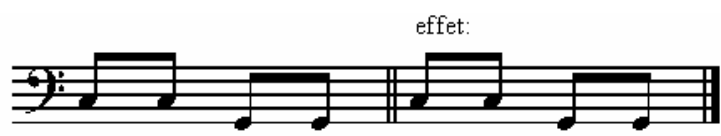

Timballes en Ré-La

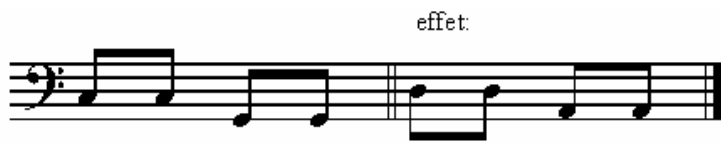

Timballes en Mi $b-S i b$

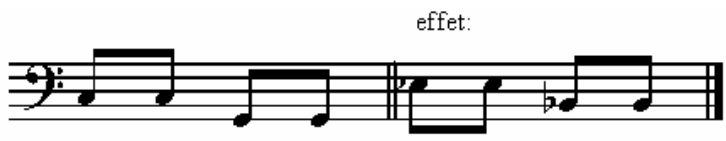

Timballes en Mi-Si

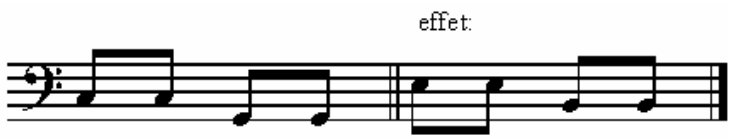

Timballes en $\mathrm{Fa}-\mathrm{Ut}$

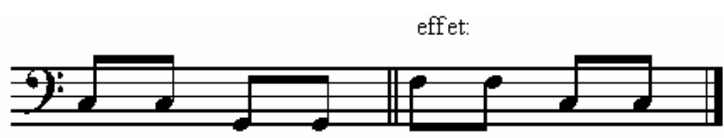

Timpani in $\mathrm{C}-\mathrm{G}$

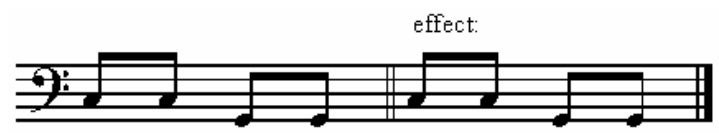

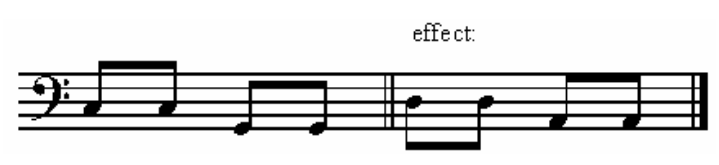

Timpani in $\mathrm{E} b-\mathrm{B} b$

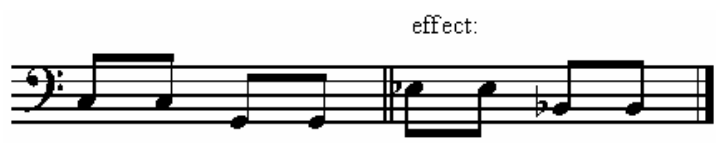

Timpani in E-B

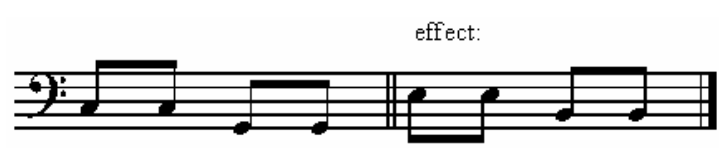

Timpani in $\mathrm{F}-\mathrm{C}$

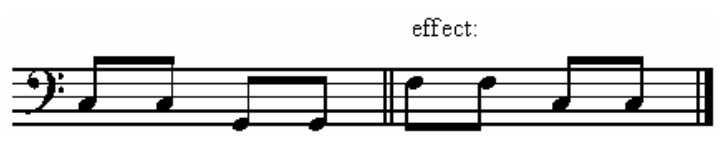

2. D'autres tout en suivant le même

procédé emploient la clef de Sol $2 .{ }^{\mathrm{me}}$ ligne; par exemple:

Timballes en $\mathrm{Si} b-\mathrm{Fa}$

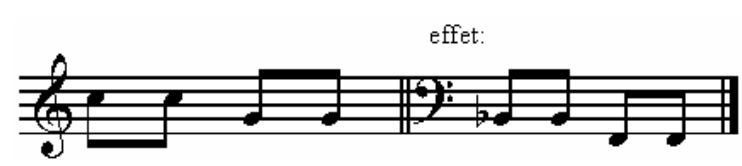

Timpani in $\mathrm{B} b-\mathrm{F}$

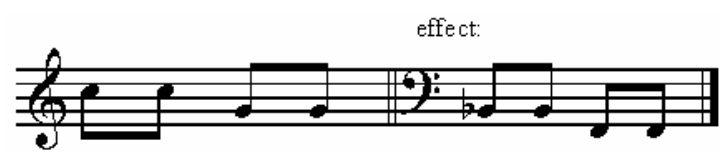


Timballes en Ut-Sol

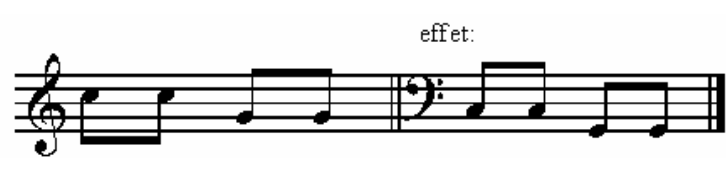

Ce qui est un véritable non-sens, parceque

la clef de Sol représente alors presque

toujours les notes environ deux octaves

plus haut, que l'instrument ne les donne en

réalité.

En général, ces deux manières sont

fautives, car, continuons à noter les

timballes d'après la première et nous

varrons de suite ce qui en adviendra.

Timballes en Sol-Ré

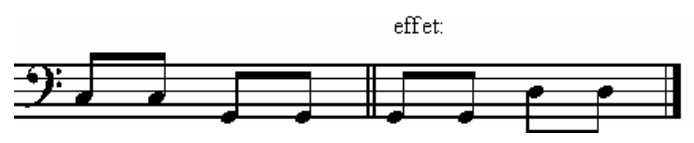

Timballes en La-Mi

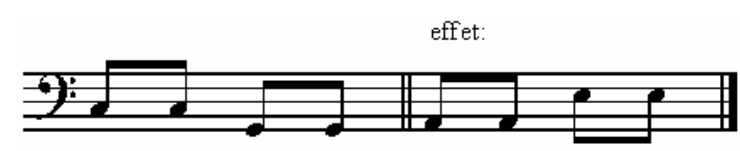

Ces deux exemples prouvent qu'on est

forcé de prendre la dominante sur la plus
Timpani in $\mathrm{C}-\mathrm{G}$

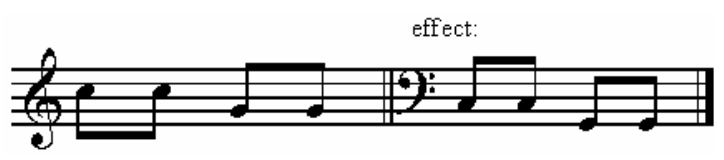

This is an absolute absurdity, because the treble clef then nearly always represents the notes approximately two octaves higher than what the instrument actually plays.

In general, these two techniques are faulty, because if we continue to notate the timpani according to the first technique, we will see what will become of it.

Timpani in G-D

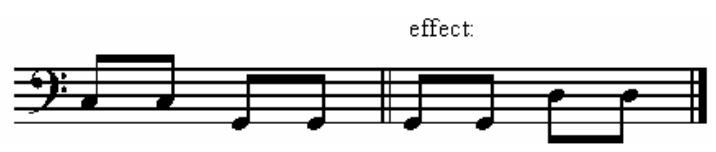

Timpani in A-E

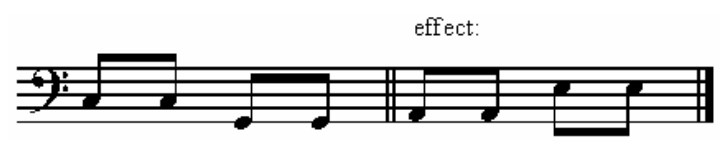

These two examples prove that one is forced to place the dominant on the 
petite timballe, parceque l'étendue des timballes ne le permet pas autrement, et ainsi, on a un intervalle de quinte su lieu d'un intervalle de quarte qu'on avait auparavant. Si le compositeur n'y fait pas attention, il en résulte souvent un effet désagréable.

Dans le ton Fa majeur, le timballier [sic] peut placer indifféremment la tonique ou la dominante sur la plus grande timballe, mais cela ne revient pas au même dans tous les cas, c'est pourquoi il vaut mieux toujours noter les timballes de la manière suivante:

Timballes en La-Ré

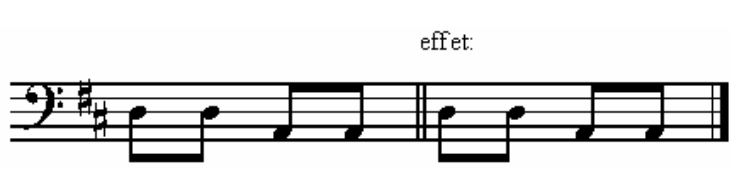

smallest timpani, because the range of the timpani does not allow otherwise; thus, one has an interval of a fifth instead of an interval of a fourth. If the composer is not careful, it would often result in an unpleasant effect.

In the key of $\mathrm{F}$ major, the timpani player can place either the tonic or dominant on the largest timpani, but that is not true in all cases: this is why it is always better to notate the timpani in the following way: Timpani in A-D

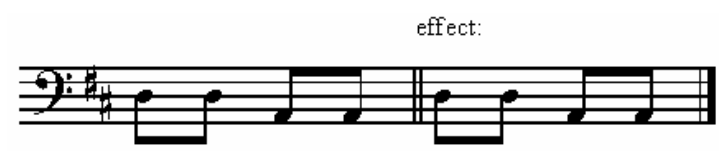

Seulement, si on écrit les notes sur la clef de Fa $4 .{ }^{\text {me }}$ ligne, il faut avoir soin d'indiquer le ton du morceau et les dièzés ou bémols à la clef, afin que l'artiste voie tout de suite, si les timballes doivent être, par exemple en Mib ou en Mi $\# \&^{\mathrm{a}}$.
However, if one writes the notes on the bass clef, one must take care to indicate the key of the piece and the sharps or flats in the key signature, so that the artist sees immediately whether the timpani must be, for example, in $E b$ or $E \#$, et cetera. 
On fait bien aussi d'écrire la tonique la

première, parceque c'est la note la plus

essentielle.

En adoptant la manière que nous venons

d'indiquer on exprimera donc avec la note

les véritables tons donnés par les timballes,

comme le démontre l'exemple ci-dessus, et

comme le prouvera mieux encore

l'exemple suivant:

Timballes en $\mathrm{Fa}-\mathrm{Ut}$

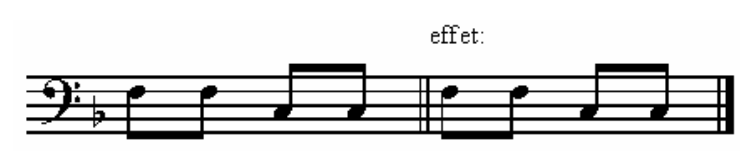

Timballes en $\mathrm{Fa}-\mathrm{Ut}$.

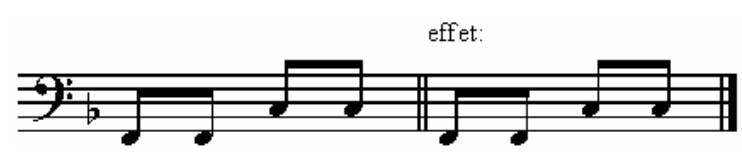

En tout cas on a ici l'avantage qu'il ne peut

pas exister de doute si la tonique ou la

dominante doit avoir le ton le plus bas.

On peut aussi quelquefois, comme

exception, employer une autre proportion

entre les deux timballes, en prenant par

exemple la tonique et la sous dominante,

ou bien la tonique, et la tonique du ton
In addition, one would do well to write to

the tonic first, because it is the most

essential note.

By adopting the procedure that we have just indicated, the notes will thus express the true pitch played by the timpani, as the above example demonstrates, and the following example will prove better still:

Timpani in $\mathrm{F}-\mathrm{C}$

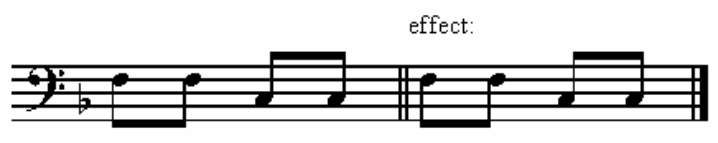

Timpani in $\mathrm{F}-\mathrm{C}$

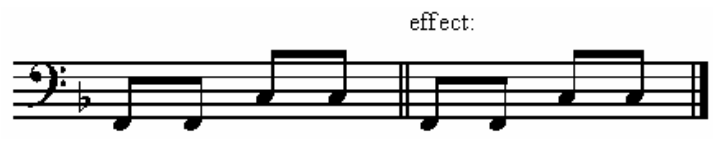

In any case, as it is described above there can be no doubt as to whether the tonic or the dominant must be the low pitch.

Also sometimes one can, as an exception, use another interval between the two timpani, by taking for example the tonic and subdominant, or the tonic and the tonic of the relative minor key; but, one 
relatif mineur, mais il ne faut recourir à cet expédient que dans le plus grand besoin, parceque le premier intervalle (tonique et dominante) est généralement adopté.

De nos jours, notre grand maître Meyerbeer a introduit dans son Opéra Robert le Diable trois timballes qui produisent un effet superbe.

Du moins, serait-il à désirer que l'on ajoutât une troisième timballe aux deux autres, afin d'avoir la tonique, la dominante et la sous-dominante, ce qui serait grandement utile, parceque le compositeur ne serait plus obligé de faire taire les timballes très souvent juste au moment où elles produiraient le plus d'effet. Absolument parlant, on ne peut pas exiger de notes tenues sur les timballes; il y a toutefois une grande différence entre les coups secs et les sons prolongés, on emploie pour les représenter des notes de valeur différente; par exemple: Timballes en Mi-Si should resort to this expedient only when absolutely necessary, because the first interval (tonic and dominant) is the more generally used.

Recently, our grand master Meyerbeer introduced three timpani into his Opera Robert the Devil, which produces a superb effect.

At the least, it would be desirable to add a third timpani to the other two, in order to have the tonic, the dominant, and the subdominant: which would be greatly useful, because the composer would no longer be obliged to silence the timpani at the exact moment when they would produce the most effect. Strictly speaking, one cannot require sustained notes on the timpani; there is however a great difference between quick blows and prolonged sounds; to represent them, one employs notes of different value; for example: Timpani in E-B 


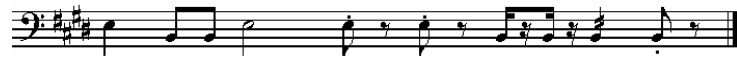

Tout ce qu'on exécute sur les instrumens à vent au moyen du coup de langue, peut se produire sur les timballes par des coups précipités, c'est pourquoi on les joue rarement seules, mais de préférence en accompagnant les cors ou les trompettes. Exemple:

Timballes en Mi $b-\mathrm{Si} b$

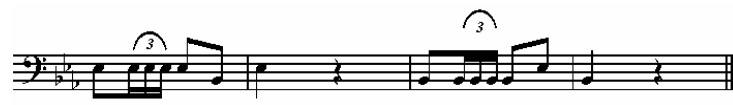

On peut aussi changer très rapidement les deux tons. Exemple:

Timballes en Sol-Ré

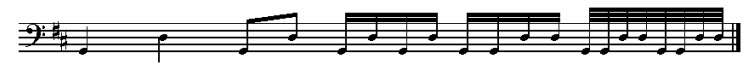

Souvent on exécute sur les timballes un

(tremolo) roulement prolongé soit sur une

seule, soit en alternant de l'une à l'autre, et

en allant du pianissimo au fortissimo, ou

vice versa, ce qui produit quelquefois le

plus grand effet.

On écrit ce roulement de la manière

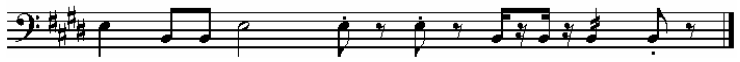

All that can be executed on the wind instruments by tonguing can also be produced on the timpani through the use of hurried blows: this is why they are only seldom played, but preferably in accompaniment to the horns or the trumpets. For example:

Timpani in $\mathrm{E} b-\mathrm{B} b$

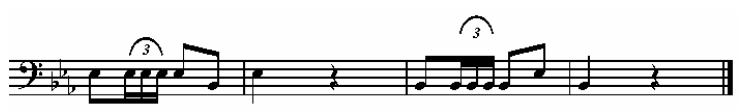

One can also change very quickly between both tones. For example: Timpani in G-D

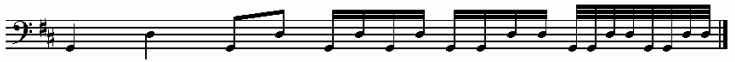

Often one plays on the timpani a (tremolo) sustained roll either on one timpani, or by alternating from to the other, and going from pianissimo to fortissimo, or vice versa (which sometimes produces the greatest effect).

One writes this roll in the following way: 
suivante:

Timballes en Ut-Sol

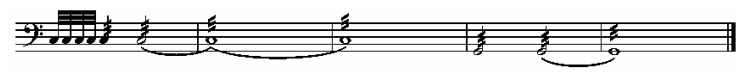

C'est-à-dire par des triples-croches; mais, dans un passage rapide on emploie des doubles-croches. Les liaisons d'une mesure à l'autre indiquent que le roulement doit continuer sans interruption.

Une manière plus courte de l'écrire est celle-ci:

Timballes en Lab-Mi b

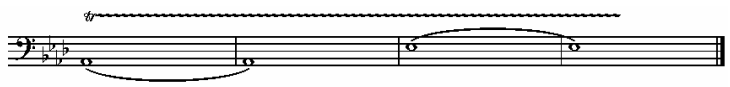

C'est-à-dire par le signe du trille qui doit se prolonger aussi longtems que le mouvement doit durer.

Lorsque dans un morceau de musique on a besoin de changer l'accord des timballes, il faut faire précéder ce changement de beaucoup de pauses, et encore ne doit-on pas s'attendre à des tons très justes.

De même que pour les cors et les trompettes on peut faire sauter la septième
Timpani in $\mathrm{C}-\mathrm{G}$

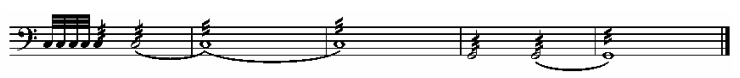

In other words in triple-eighth notes; but in a fast passage one uses sixteenth notes.

The connections from one measure to another indicate that the roll must continue without interruption.

A shorter way of writing is this:

Timpani in $\mathrm{A} b-\mathrm{E} b$

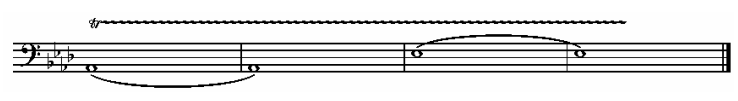

In other words, the trill sign indicates that the roll must be sustained as long as the movement lasts.

When one needs to change the tuning of the timpani in a piece of music, it is necessary to precede this change by many rests, and still one should not expect the pitch to be exactly accurate.

Just as for the horns and the trumpets, one can skip the seventh on the timpani; For 
sur les timballes; Exemple:

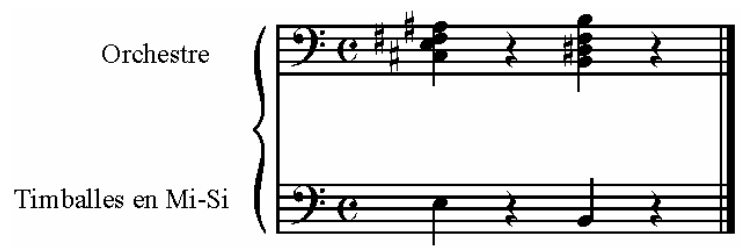

Seulement, il faut alors que le ton le plus haut forme la septième et saute sur la basse; le contraire n'est pas praticable.

Ordinairement les timballes marchent avec la basse, mais on peut aussi les faire jouer avec tous les autres accords, pour vu que dans ces accords se trouve un de leurs deux tons, lors même que ce ne serait pas celui de la basse; il faut seulement éviter les progressions défendues par les règles de la composition, ou celles qui produiraient un mauvais effet.

Des solos, comme coups isolés, tremolo et autres figures sont quelquefois d'un très bel effet, soit que les timballes jouent toutes seules, soit qu'elles jouent avec accompagnement d'autres instrumens; toutefois, il ne faut pas y recourir trop souvent. example:

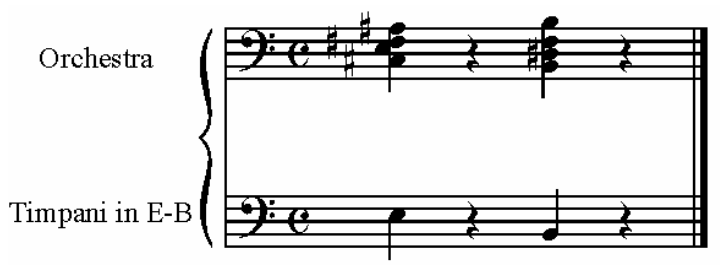

It is however necessary for the highest key to form the seventh and jumps to the bass; the opposite is not practicable.

Usually the timpani play with the bass, but since they can be played with all the other chords, provided that these chords possess one of the timpani's two keys (even though it would not be the bass'); one must only take care to avoid the progressions forbidden by the rules of composition, or those which would produce a unpleasant effect.

Solos such as isolated blows, rolls, and other figures sometimes create a very beautiful effect, whether the timpani play alone, or with the accompaniment of other instruments; however, one should not resort to such solos too often. 
Autrefois, on avait dans chaque régiment

de cavalerie deux timballes qui faisaient

pour ainsi dire la basse des trompettes,

mais de nos jours on les a abandonnées.

On a une Méthode pour les timballes

d'Altenburg.

LE TAMBOURIN. (Tambour de basque).

Cette petite espèce de timballes

s'employait dans le musique militaire, avec

la grosse caisse, le triangle $\&^{\mathrm{a}}$; on tenait le

tambour de la main gauche et on le frappait

avec la droite ou bien on frôlait avec un

doigt mouillé. $^{141}$

On le notait par l'Ut de la clef de Sol

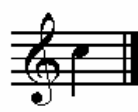

mais le plus souvent on n'écrivait

pas de partie séparée pour cet instrument; il

suivait la même partie que la grosse caisse.

Pour désigner le passage où l'on doit frôler

avec le doigt, il faut écrire au dessus de la

note (glissez avec le doigt), comme ci-

dessous.
Formerly, in each cavalry regiment there were two timpani that performed, so to speak, like low trumpets, but nowadays they have been abandoned.

There is a method for the timpani by

Altenburg.

THE TAMBOURINE (Basque

\section{Tambourine)}

This small type of timpani was used in military music, with the bass drum, the triangle, and so forth; the drum was held with the left hand and one struck it with the right-or passed very close to with a wet finger.

One notated it as $\mathrm{C}$ of the treble clef

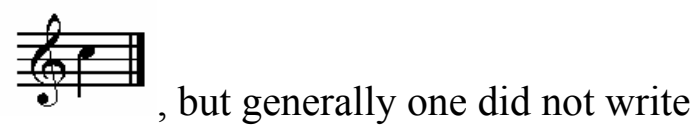

a separate part for this instrument; it

followed the same part as the bass drum.

To indicate the passage where one must pass very close to the tambourine with the finger, it is necessary to write "gliss with the finger" above the note, as indicated 
below:

glissez avec le doigt

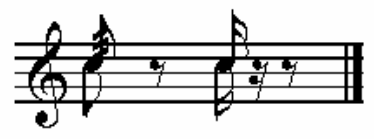

gliss with the finger

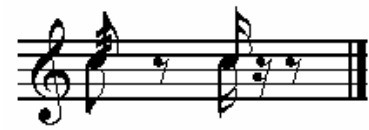

\section{LA CAISSE ROULANTE (Ou tambour}

TENOR DRUM

roulant)

On l'exprime en notes par un ton

One expresses this instrument in notes by quelconque de la clef de Sol 2 me ligne, et any key on the treble clef, in order to le plus souvent on e'écrit sur la même minimize the number of staves used portée que le triangle pour économiser les portées, dans la partition. overall, it is generally written on the same staff as the triangle in the score.

La caisse roulante peut donner des coups The snare drum can produce isolated isolés ou des roulemens [sic] qu'on désigne blows or rolls which are indicated in absolument de la même manière que pour exactly the same way as the timpani; but les timballes; seulement avec une autre with another note; for example: note; par exemple:

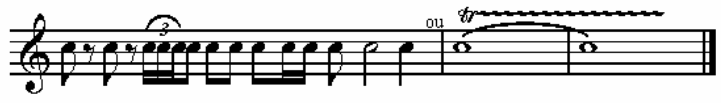

On emploie quelquefois cet instrument pour des solos; il se prête très bien au crescendo et au decrescendo. LA CAISSE CLAIRE (Ou tambour)

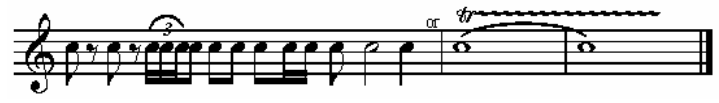

Sometimes this instrument is used for solos; it lends itself very well to the crescendo and decrescendo. The SIDE DRUM (Or tambour) 
Le tambour diffère de la caisse roulante en ce qu'il s'emploie de préférence pour des coups secs et des roulemens courts. Les roulemens prolongés et surtout en solo, sont exécutés par la caisse roulante tandis que le tambour se repose.

Les notes peuvent être placées sur tel endroit qu'on veut de la portée ordinairement ou les désigne comme celles de la caisse roulante.

\section{LA GROSSE CAISSE}

Cet instrument, de même que ceux qui précèdent n'a pas de ton déterminé. On désigne ordinairement sa partie par un Ut de la petite octave, (clef de Fa).

Il ne faut pas lui donner de coups trop précipités parceque, dans ce cas, l'exécution en est toujours un peu défectueuse.

La grosse caisse s'écrit d'habitude, sur la même portée que les cymbales. La note à frapper peut se placer sur tous les tems de la mesure; mais naturellement le $1^{\text {er }}$ et le
The tambour differs from the side drum in that it is preferably used for quick blows and short rolls. Especially in solo, sustained rolls are played by the side drum while the tambour rests.

The notes can be placed on the staff wherever desired, or indicated as those of the side drum.

\section{THE BASS DRUM}

This instrument, as well as the preceding instruments, does not have a specific key. One usually indicates its part as a $\mathrm{C}$ of the small octave (bass clef).

One should not give it hurried blows because, in this case, the execution is always somewhat defective.

The bass drum is usually written on the same staff as the cymbals. The note to be struck can be placed on any of the beats of the measure; but naturally the first and the 
3 me tems sont les meilleurs.

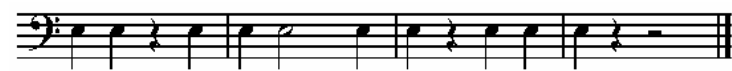

On se sert quelquefois au théâtre, de la grosse caisse toute seule pour imiter les coups de canons; on l'emploie aussi en outre réunie aux cymbales, triangle, \&.

\section{LE TRIANGLE}

Le triangle accompagne presque toujours la grosse caisse, les cymbales, \& cependant, on s'en sert quelquefois dans l'orchestre, sans les autres instrumens de cette catégorie. Il n'a pas non plus de ton déterminé, et on le désigne ordinairement dans la partition par l'Ut de la clef de Sol, $2 \mathrm{me}$ ligne.

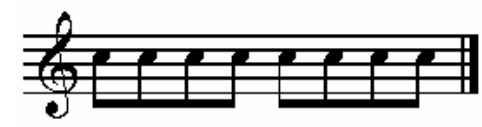

Il donne à volonté des coups lents ou rapides qu'on peut exécuter avec une grande vitesse, ou prolonger d'une certaine valeur; par exemple: third beats are the best.

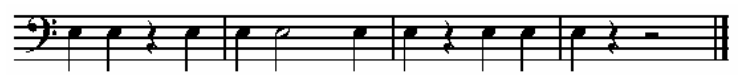

Sometimes it is used in the theatre

because the bass drum alone can imitate

gunshots; in addition it is also played

together with the cymbals, triangle, and

the like.

\section{THE TRIANGLE}

The triangle almost always accompanies the bass drum and the cymbals. However, it is sometimes used in the orchestra without the others instruments of this category. It does not have a specific key, and it is usually designated in the score as $\mathrm{C}$ on the treble clef.

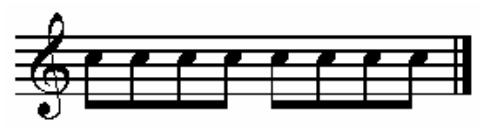

It produces slow or rapid blows as desired, which one can execute at high speed or sustain for a specified value; for example: 


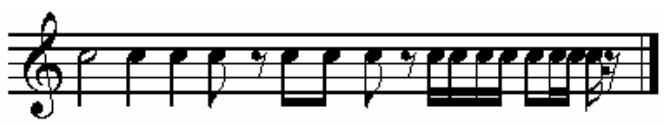

Le triangle comme les timballes peut produire un tremolo qu'on exprime en notes par des triples-croches ou autres notes de courte durée et aussi par le signe du trille.

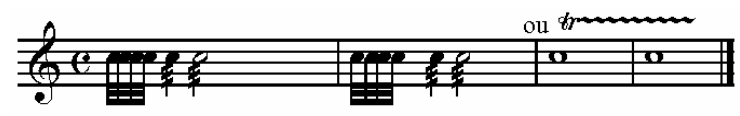

Comme nous l'avons déjà dit, il s'emploie quelquefois en solo dans différentes figures; par exemple:

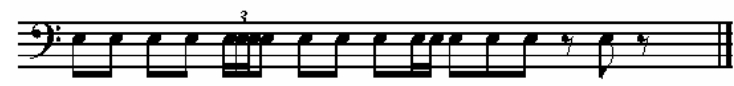

\section{LES CYMBALES}

Les cymbales marchent toujours avec la grosse caisse, le triangle, \&a et n'ont point de ton déterminé; on les exprime en notes par un ton quelconque de la clef de Fa; ordinairement par un Sol:

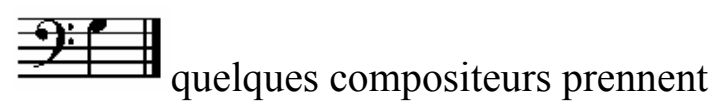

Ut de la clef de Sol:

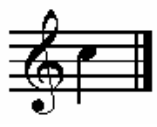

$$
\text { mais Sol de }
$$
la clef de Fa vaut mieux, parcequ'alors on

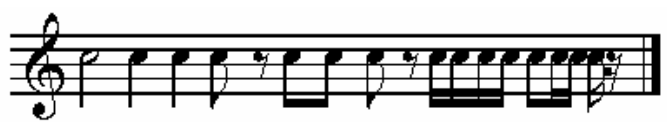

The triangle, like the timpani, can produce a tremolo that is expressed in thirtysecond notes, other notes of short duration, or also by the trill sign.

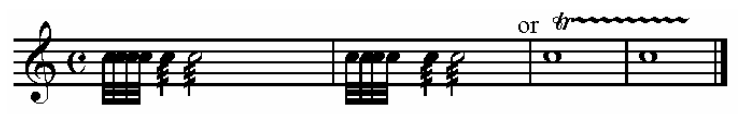

As we already said, it is sometimes used solo in various figures; for example:

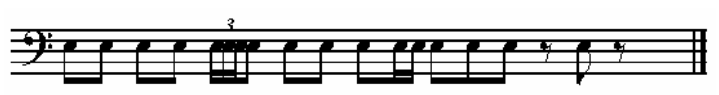

\section{THE CYMBALS}

The cymbals always play with the bass drum, triangle, and the like and do not have a specific key. They are notated with any key of the bass clef; but usually a
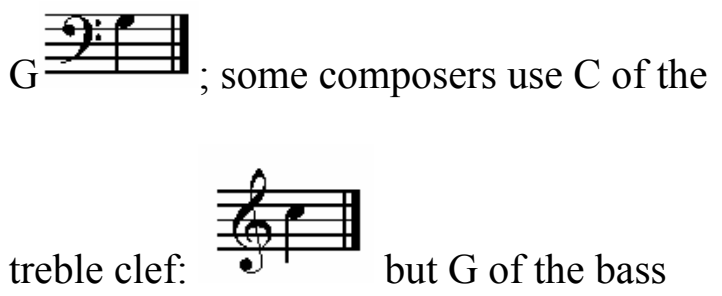

clef is better, because then the cymbals part can be written on the same staff as the 
peut écrire la partie des cymbales sur la

même portée que la grosse caisse, surtout

quand il faut encore de l'espace pour

ajouter en dessus la partie de triangle;

comme par exemple:

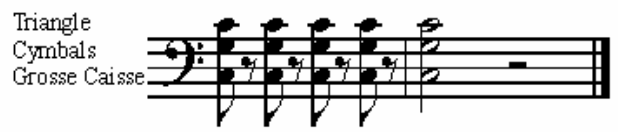

Les cymbales frappent ordinairement les

mêmes coups que la grosse caisse;

(quelquefois on les emploie seules pour

produire un certain effet). Les coups de

cymbales ne doivent pas se succéder trop

rapidement, du reste, cet instrument

marchant presque toujours avec la grosse

caisse, tout ce qu'on a dit, relativement à

cette dernière pour la vitesse et les tems de

la mesure, s'applique également ici.

Si on veut que les cymbales résonnent

pianissimo en touchant le bord d'une

cymbale avec l'autre, il faut l'écrire comme

suit:

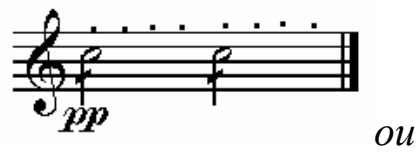

bass drum, especially when one needs

space to add the triangle part on top, such

as:

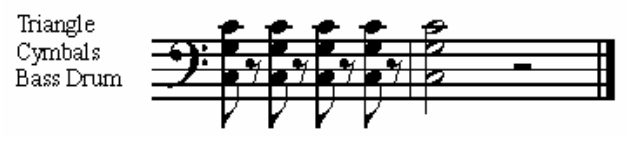

The cymbals usually strike the same

blows as the bass drum; (sometimes they

are used alone to produce a certain effect).

The cymbal crashes should not follow one

another too quickly; moreover, this

instrument almost always plays with the

bass drum. All that was said relative to

the latter regarding speed and time of

measure applies here also.

If it is desired that the cymbals ring

pianissimo by touching the edge of one

cymbal with the other, it should be written as follows:

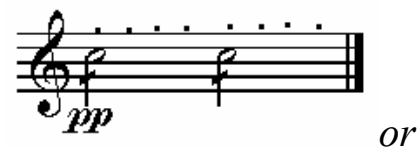




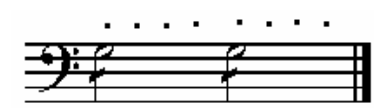

Si on désire au contraire des coups forts et retentissants, on écrira:
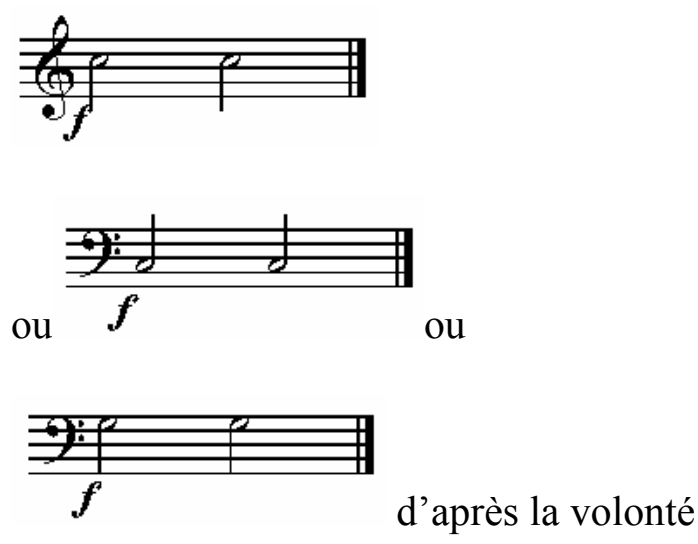

du compositeur.

\section{LE CHAPEAU CHINOIS}

On l'emploie seulement dans la musique militaire et toujours avec la grosse caisse; on n'écrit point pour lui de partie à part; celui qui en joue regarde dans la partie de la grosse caisse et donne les mêmes coups. On pourrait, au besoin, désigner sa partie à

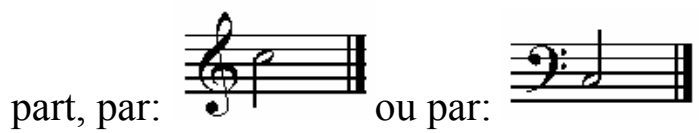

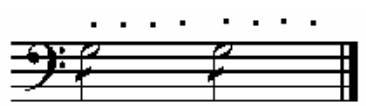

If, on the contrary, one desires strong and resounding blows, one will write:
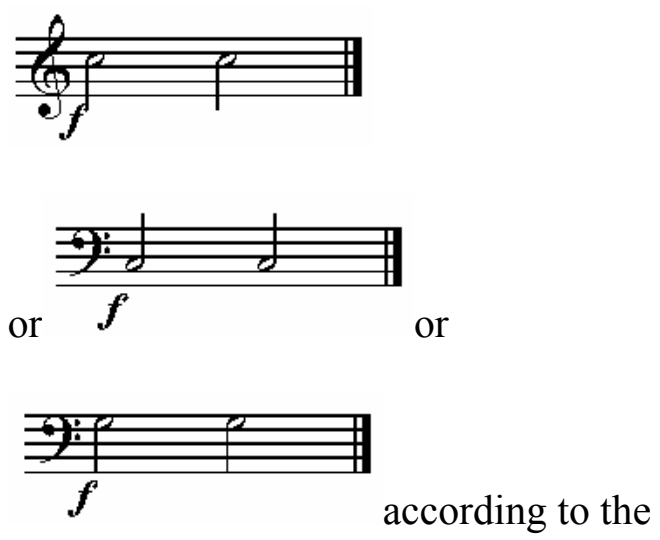

will of the composer.

\section{THE TURKISH CRESCENT}

It is only used in military music, and always used with the bass drum. A separate part is not written for it; is the artist playing it reads the bass drum's part and strikes the same blows.

One could, if need be, indicate its part

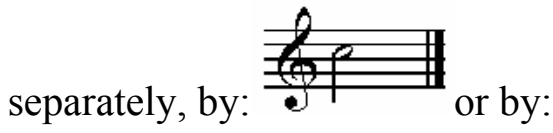

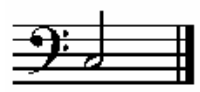

THE TAM-TAM 
On ne s'en sert que dans des scènes de terreur, ou dans la musique funèbre. Le tam-tam a un timbre tout-à-fait particulier, on le désigne par l'Ut de clef de Fa:

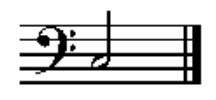

(En Turquie cet instrument sert à appeler les fidèles à la Mosquée; les prêtres le frappent du haut des minarets.)

\section{LE BEFFROI}

Les coups de beffroi se désignent aussi par l'Ut de clef de Fa:

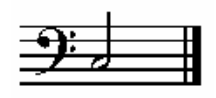

\section{LA CLOCHE}

La cloche s'emploie quelquefois dans la musique d'Opéra et comme on peut l'accorder dans un ton quelconque, on l'écrit chaque fois sur la note dont elle donne le ton, ainsi c'est le morceau de musique qui détermine toujours la note à employer; par exemple:
It is used only in terror scenes, or in funeral music. The tam-tam has a very specific timbre; it is indicated as $\mathrm{C}$ of the bass clef:

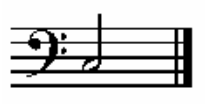

(In Turkey this instrument is used to call the faithful to the Mosque; the priests strike it from the tops of the minarets.) THE BELFRY

The blows of the belfry are also indicated by $\mathrm{C}$ of bass clef:

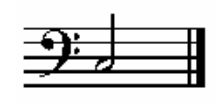

\section{THE BELL}

The bell is sometimes used in opera music, and as one can tune it to any pitch, each time it is written on the sounding pitch; thus it is the piece of music which always determines the note to be used; for example:

Bell in $\mathrm{G}$

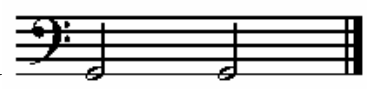


Cloche en Sol

Cloche en $\mathrm{La}$ 要

Il dépend du compositeur de choisir le ton

le plus convenable. Mr. Rossini a employé

une cloche en Sol, dans l'Opéra de

Guillaume Tell. Mr. Meyerbeer en a

employé une en Si dans l'Opéra de Robert

le Diable.

\section{LE CARILLON}

Le carillon consiste en un certain nombre de petites cloches s'échelonnant par degrés successifs, diatoniquement et aussi

chromatiquement. Il y en a de plusieurs

espèces, mais les meilleurs sont munis d'un

clavier qui ment en mouvement de petits

marteaux frappant sur les cloches.

Il y a des carillons de 2,3 et jusqu'à 4

octaves.

On n'emploie guère cet instrument que

pour de la musique de danse.

LES CASTAGNETTES

On emploie surtout les castagnettes en
Bell in A

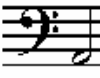

It is the composer who must choose the most suitable key. Mr. Rossini used a bell in $\mathrm{G}$ in the opera William Tell. Mr. Meyerbeer used a bell in B in the opera Robert le diable.

\section{THE CHIME}

The chime consists of a given number of

small bells spread out in successive

degrees, diatonically and also

chromatically. There are several types of

them, but the best is furnished with a

keyboard that provides movement like

that of small hammers, striking the bells.

There are chimes of 2, 3 and up to 4

octaves.

This instrument is hardly used, except for dance music.

\section{THE CASTANETS}

One often uses the castanets in Spain and 
Espagne et dans le midi de la France pour accompagner la danse et le chant.

On les introduit souvent aussi dans la musique d'Opéra, pour des Ballets, ou Airs nationaux.

Les castagnettes contribuent beaucoup à rendre le rythme bien sensible et elles communiquent un caractère de gaîté à la danse ou au chant.

Comme cet instrument n'a pas de ton déterminé, il est indifférent de le désigner par telle ou telle note, cependant on le désigne d'habitude par Sol de la 3me petite in the South of France to accompany dance and song. They are used in opera music, for the ballet, or national airs.
The castanets help to render the rhythm sensitive; they imbue a sense of gaiety in either dance or song.

As this instrument has no specific key, the indication of this or that note is unnecessary; however one usually indicates it as $\mathrm{G}$ of the third small octave. octave.

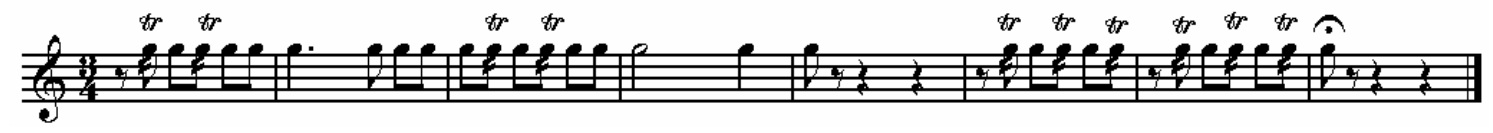

On écrit tr: au dessus des notes pour indiquer qu'on doit exécuter une espèce de trille sur l'instrument.

Les castagnette s'emploient surtout pour accompagner le boléro danse Espagnole mêlée de chant.

LE SYSTRE (Systrum)
One writes "tr:" over the notes to indicate that one must play a type of trill on the instrument.

The castanets are used especially for the accompaniment of the Spanish bolero dances mixed with song. The Systre (Systrum) 
Le systre était une espèce de cercle qu'on tenait de la main gauche au moyen d'un manche en saille; d'un côté à l'autre de la circonférence étaient fixées des tiges métalliques qu'on faisait résonner par des coups de baguette. Cette baguette nommée Plectrum se tenait de la main droite.

Le systre était en usage chez les anciens dans beaucoup de cérémonies religieuses; on en retrouve des traces dans les auteurs latins:

Isis et irato feriat mea lumina systro (Juvenal)

Si quis ploratur collo tibi vernula

pendet,

Hac quatiat tenerâ, garrula

systra manu. (Martial)

Il ne faut pas, ainsi qui l'ont fait quelques

théoriciens distingués, confondre le systre (sistrum) avec le sistre qui est une espèce de guitare dont j'ai parlé ci-dessus.
The systre was a type of circle that one held with the left hand by means of a handle. From one side of the circumference to the other, metal rods were affixed; these were made to resonate by blows from a small stick. This stick, called the plectrum, was held with the right hand.

The systre was used by the ancients in many religious ceremonies; one finds mentions of the instrument in the Latin authors:

\section{Let Isis strike my eyes with}

her angry Sistrum (Juvenal)

If a little slave born in your

house hugs you, begging to play the sistra,

Then let her delicate hands

touch the joyful instrument. (Martial)

Though some distinguished theorists have done so, one should not confuse the systre (sistrum) with the sister, which is a kind of guitar about which I have spoken above. 


\section{REMARQUE}

J'aurais encore pu donner la description

d'une foule d'autres instrumens tant

anciens que modernes, mais ce détail

m’aurait entraîné trop loin sans un grand

profit pour le lecteur, car les instrumens

que j'ai omis sont très peu répandus et on

peut dire qu'ils cessent de vivre en voyant

le jour; chaque année voit encore paraître

une multitude de ces instrumens mort-nés

qui disparaissent quelques semaines après

leur apparition; il aurait donc été à la fois

inutile et fastidieux d'en donner la

nomenclature.

Une autre catégorie que j'ai aussi dû

repousser de ce volume est celle des

instrumens dérivés; c'est-à-dire des

instrumens qui ne diffèrent que par une

légère modification de la famille qui leur a donné naissance.

Mon but a été d'offrir aux jeunes

compositeurs un ouvrage complet, mais

concis et débarrassé toute addition

\section{NOTICE}

I could have given the description of a

many other instruments, old as well as

modern; but this detail would have led me

too far afield without any great profit to

the reader, because the instruments which

I omitted are not well-known, and one can

say that they cease to exist shortly after

their actual invention; each year still sees

a multitude of these still-born instruments

that disappear a few weeks after their

appearance; it would thus have been at the

same time useless and tiresome to give

their nomenclature.

Another category that I also had to omit

from this volume is that of the derivative

instruments; in other words, instruments

which differ only by slight modification

from the family from which they

originate.

My goal was to offer to young composers

a complete work, but one that is concise

and unencumbered by any superfluous 


\footnotetext{
${ }^{1}$ For more detailed information about Kastner's archives see Alfred Loewenberg, "Kastner, Jean Georges," in Grove's Dictionary of Music and Musicians, ed. Charles Grove (London: MacMillan, 1954), 708 and FrançoisJoseph Fétis, "Kastner, Jean-Georges," in Biographie universelle des musiciens et bibliographie générale de la musique 2nd edn (Paris: Libraireie de Frimin Didot Frères, 1866) 480.
}

${ }^{2}$ The dates of Kastner's birth disagree in sources. Fétis's article in the Biographie universelle des musicians indicates that Kastner was born in 1811, while all other sources used in this paper indicated 1810.

${ }^{3}$ François-Joseph Fétis, "Kastner, Jean-Georges," in Biographie universelle des musiciens et bibliographie générale de la musique 2nd edn (Paris: Libraireie de Frimin Didot Frères, 1866) 480.

${ }^{4}$ For a thorough listing of Kastner's works, see Hermann Ludwig's Johann Georg Kastner, ein elsässischer Tondichter, Theoretiker und Musikforscher; sein Werden und Wirken. (Leipzig: Breitkopf, 1886).

${ }^{5}$ François-Joseph Fétis, “Kastner, Jean-Georges," in Biographie universelle des musiciens et bibliographie générale de la musique 2nd edn (Paris: Libraireie de Frimin Didot Frères, 1866) 480.

${ }^{6}$ Thomasin La May and Stewart A. Carter, "Kastner, Jean-Georges," The New Grove Dictionary of Music Online ed. L. Macy (Accessed 23 January 2002), <http://www.grovemusic.com>, Hermann Ludwig, Johann Georg Kastner, ein elsässischer Tondichter, Theoretiker und Musikforscher; sein Werden und Wirken (Leipzig: Breitkopf, 1886) 349-350.

${ }^{7}$ H G Farmer and Raoul Camus, "Bandmasters," The New Grove Dictionary of Music Online ed. L. Macy (Accessed 23 January 2002), <http://www.grovemusic.com>

${ }^{8}$ Thomasin La May and Stewart A. Carter, "Kastner, Jean-Georges," The New Grove Dictionary of Music Online ed. L. Macy (Accessed 23 January 2002), <http://www.grovemusic.com>.

${ }^{9}$ François-Joseph Fétis, "Kastner, Jean-Georges," in Biographie universelle des musiciens et bibliographie générale de la musique 2nd edn (Paris: Libraireie de Frimin Didot Frères, 1866) 481. According to Ludwig, it was published in 1835 .

${ }^{10}$ Thomasin La May and Stewart A. Carter, "Kastner, Jean-Georges," The New Grove Dictionary of Music Online ed. L. Macy (Accessed 23 January 2002), <http://www.grovemusic.com>.

${ }^{11}$ Hermann Ludwig, Johann Georg Kastner, ein elsässischer Tondichter, Theoretiker und Musikforscher; sein Werden und Wirken. (Leipzig: Breitkopf, 1886) 351.

${ }^{12}$ François-Joseph Fétis, "Kastner, Jean-Georges," in Biographie universelle des musiciens et bibliographie générale de la musique 2nd edn (Paris: Libraireie de Frimin Didot Frères, 1866) 481.

${ }^{13}$ Ibid.

${ }^{14}$ Ibid, 482.

${ }^{15}$ Hermann Ludwig, Johann Georg Kastner, ein elsässischer Tondichter, Theoretiker und Musikforscher; sein Werden und Wirken. (Leipzig: Breitkopf, 1886) 357.

${ }^{16}$ François Castil-Blaze, "Revue critique. Romances de Georges Kastner," La Revue et Gazette musicale, (24 January 1841), 53. 
${ }^{17}$ François Castil-Blaze, "Revue critique. Romances de Georges Kastner," La Revue et Gazette musicale, (24 January 1841), p. 54.

${ }^{18}$ Georges Kastner, arr. Sigurd Rascher, “Sextour,” score (Oswego, New York: Ethos, 1982), 2.

${ }^{19}$ Claus Raumberger and Karl Ventzke: "Saxophone," The New Grove Dictionary of Music Online ed. L. Macy (Accessed 24 January 2003), <http://www.grovemusic.com>.

${ }^{20}$ Ibid.

${ }^{21}$ François-Joseph Fétis, "Kastner, Jean-Georges," in Biographie universelle des musiciens et bibliographie générale de la musique 2nd edn (Paris: Libraireie de Frimin Didot Frères, 1866) 482.

${ }^{22}$ Claus Raumberger and Karl Ventzke: "Saxophone," The New Grove Dictionary of Music Online ed. L. Macy (Accessed 24 January 2003), <http://www.grovemusic.com>.

${ }^{23}$ Georges Kastner, arr. Sigurd Rascher, Sextour, (Oswego, New York: Ethos, 1982), 2.

${ }^{24}$ Georges Kastner, Manuel général de musique militaire à l'usage des armées françaises, comprenant: $1^{\circ}$ l'esquisse d'une histoire de la musique militaire chez les différents peuples, depuis l'antiquité jusqu'à nos jours; $2^{\circ}$ la nouvelle organisation instrumentale prescrite par l'ordonnance ministérielle du 12 août 1845; $3^{\circ}$ la figure et la description des instruments qui la composent, M. Adolphe Sax; $4^{\circ}$ quelques instructions sur la composition et l'exécution de la musique militaire (Paris: Firmin Didot Frères, 1848).

${ }^{25}$ François-Joseph Fétis, "Kastner, Jean-Georges," in Biographie universelle des musiciens et bibliographie générale de la musique 2nd edn (Paris: Frimin Didot Frères, 1866) 482-483.

${ }^{26}$ Unsigned, “Les Danses des Morts,” La Revue et Gazette musicale, (2 May 1852), p. 142.

${ }^{27}$ François-Joseph Fétis, “Kastner, Jean-Georges," in Biographie universelle des musiciens et bibliographie générale de la musique 2nd edn (Paris: Frimin Didot Frères, 1866) 485.

${ }^{28}$ Unsigned article, La Revue et Gazette musicale, (22 December 1867), p. 408.

${ }^{29}$ For a more extensive bibliographic listing, see: ed. Howard Mayer Brown and Stanley Sadie, Performance Practice: Music before 1600 (New York: Norton, 1990).

${ }^{30}$ Beth Bullard, "Virdung, Sebastian," The New Grove Dictionary of Music Online ed. L. Macy (Accessed 24 January 2003), <http://www.grovemusic.com>.

${ }^{31}$ Hans Bartenstein, "Die frühen Instrumetationslehren bis zu Berlioz” Archiv für Musikwissenschaft, 28 (1971), p. 98.

${ }^{32}$ Adam Carse, “Text-books on orchestration before Berlioz,” Music and Letters, 22 (1941), p. 26.

33 George Buelow, “Mattheson, Johann," The New Grove Dictionary of Music Online ed. L. Macy (Accessed 24 January 2003), <http://www.grovemusic.com>.

${ }^{34}$ For a more lengthy listing of such treatises, refer to the references contained within the text of the treatise.

${ }^{35}$ George Buelow, "Majer, Joseph Friedrich Bernhard Caspar, Johann," The New Grove Dictionary of Music Online ed. L. Macy (Accessed 24 January 2003), <http://www.grovemusic.com>.

${ }^{36}$ Adam Carse, “Text-books on orchestration before Berlioz,” Music and Letters, 22 (1941), p. 27. 
${ }^{37}$ Frederic Merritt, "La Borde, Jean-Baptiste de," The New Grove Dictionary of Music Online ed. L. Macy (Accessed 24 January 2003), <http://www.grovemusic.com>.

${ }^{38}$ Barry S. Brook, Richard Viano, and Albert R. Rice, "Roeser, Valentin," The New Grove Dictionary of Music Online ed. L. Macy (Accessed 24 January 2003), <http://www.grovemusic.com>.

${ }^{39}$ Hugh MacDonald, Berlioz's Orchestration Treatise: A Translation and Commentary (Cambridge: Cambridge University Press, 2002) xxv.

${ }^{40}$ Hans Bartenstein, "Die frühen Instrumetationslehren bis zu Berlioz" Archiv für Musikwissenschaft, 28 (1971), p. 103.

${ }^{41}$ Adam Carse, “Text-books on orchestration before Berlioz," Music and Letters, 22 (1941), p. 28.

${ }^{42}$ Hugh MacDonald, Berlioz's Orchestration Treatise: A Translation and Commentary (Cambridge: Cambridge University Press, 2002) xxvi.

${ }^{43}$ Hans Bartenstein, "Die frühen Instrumetationslehren bis zu Berlioz” Archiv für Musikwissenschaft, 28(1971), p. 110 .

${ }^{44}$ Ian D. Bent and Anthony Pople, "Analysis," The New Grove Dictionary of Music Online ed. L. Macy (Accessed 24 January 2003), <http://www.grovemusic.com>.

${ }^{45}$ Hugh MacDonald, Berlioz's Orchestration Treatise: A Translation and Commentary (Cambridge: Cambridge University Press, 2002) xxvi.

${ }^{46}$ Hugh MacDonald, Berlioz's Orchestration Treatise: A Translation and Commentary (Cambridge: Cambridge University Press, 2002) xxviii.

${ }^{47}$ Ibid, xxviii

${ }^{48}$ Anne-Marie Riessauw, "Gevaert, François-Auguste," The New Grove Dictionary of Music Online ed. L. Macy (Accessed 24 January 2003), <http://www.grovemusic.com>.

${ }^{49}$ Rosemary Williamson, "Prout, Ebenezer," The New Grove Dictionary of Music Online ed. L. Macy (Accessed 24 January 2003), <http://www.grovemusic.com>.

${ }^{50}$ Ebenezer Prout, Instrumentation (Philadelphia: Diston, n.d.), 3.

${ }^{51}$ Ebenezer Prout, Instrumentation (Philadelphia: Diston, $n . d$. ), 59.

${ }^{52}$ Mainzer, “Traité général d’Instrumentation,” La Revue et Gazette musicale, (17 September 1837), p. 417.

${ }^{53}$ Refer to page 31 of this document.

${ }^{54}$ Refer to page 123 of this document.

${ }^{55}$ Hugh MacDonald, Berlioz's Orchestration Treatise: A Translation and Commentary (Cambridge: Cambridge University Press, 2002) 99-100.

${ }^{56}$ Refer to page 150 of this document.

${ }^{57}$ Ed. Pierre Citron, Hector Berlioz: Correspondance générale, vol. 5, 1855-1859, (Paris: Flammarion, 1989), 592593. 
${ }^{58}$ Hugh MacDonald, Berlioz's Orchestration Treatise: A Translation and Commentary (Cambridge: Cambridge University Press, 2002) xvii-xviii.

${ }^{59}$ Berlioz advises his readership to consult the Kastner Traité for information on little-known instruments such as the poikilorgue, sistrum, and anémocorde. Berlioz stated that his purpose was to present only the modern instruments used in the orchestra (See MacDonald's translation, p.293). Curiously, Richard Strauss's translation of the same passage in the Berlioz treatise advises that "readers desirous of knowing more about them are referred to scientific literature on the subject." (See Theodore Front's translation, p.299.)

${ }^{60}$ Refer to page 278 of this document.

${ }^{61}$ Hugh MacDonald, Berlioz's Orchestration Treatise: A Translation and Commentary (Cambridge: Cambridge University Press, 2002), 283.

${ }^{62}$ Ibid.

${ }^{63}$ Refer to page 281 of this document.

${ }^{64}$ Hugh MacDonald, Berlioz's Orchestration Treatise: A Translation and Commentary (Cambridge: Cambridge University Press, 2002), 286.

${ }^{65}$ Refer to page 282 of this document.

${ }^{66}$ Hugh MacDonald, Berlioz's Orchestration Treatise: A Translation and Commentary (Cambridge: Cambridge University Press, 2002), 274.

${ }^{67}$ La voix qu'on appelle, en France, Haute-Contre, n'est autre chose qu'une de Ténor avec quelques notes de plus à l'aigu. On n'a jamais employé ce genre de voix dans aucun autre pays.

Dans les anciens Opéras Français, on retrouve assez fréquemment la voix de Haute Contre; mais c'est que le diapason musical était d'un ton plus bas que de nos jours; et, par cette raison, beaucoup de Chœurs, même de Gluck ne peuvent plus s'exécuter actuellement; aussi, aujourd'hui n'emploie-t-on plus ce diapazon dans les Chœurs; on l'écrivait sur la clef d'Ut 3me ligne, ce qui fit croire dans d'autres pays, que cette partie devait être chantée par des voix de femmes, et ainsi on confondait la Haute-Contre avec le Contr'alto.

Il y a quelques Ténors qui peuvent monter de poitrine jusqu'à l'Ut naturel de la 3me petite octave; on les appelle encore en France: Haute-Contre./

The voice that is called Haute-Contre in France is nothing more than another type of tenor, with more notes in the higher register. This type of voice has never been used in any other country.

In old French operas, one finds the Haute-Contre voice rather frequently; the tuning pitch was a tone lower than what is used today; by this reasoning, many choruses, (even Gluck's) can no longer perform it; also, today one no longer employs this tuning pitch in the choruses; one wrote it on the $\mathrm{C}$ clef, third line, which caused musicians in other countries to believe that this part was to be sung by women's voices,and thus the Haute-Contre was confused with the Contr' alto.

There are some tenors who can, using a "chest voice", sing up to natural C of the third small octave. In France, these tenors are still called: Haute-Contre.

${ }^{68}$ Antoine Bailleux, Methode pour apprendre facilment la musique vocale et instrumentale: ou tous les principes sont developés avec beaucoup de clarté, et cent leçons dans le gout nouveau à une et à deux parties, ce qui enseigne en très peu de tems a solfier sur toutes les clefs, toutes les mesures et tous les tons (Paris: L'auteur, 1770).

Antoine Bailleux, Méthode de chant (Paris: n.p., 1760). 
Léon La Borde, Chansonnier de M. le Marquis de Laborde (n.p., 1470).

Alexandre Étienne Choron, Manuel de chant classique: contenant un choix de pièces de chant à une ou plusieurs voix avec ou sans basse continue, de divers genres; telles que: cantates, ricercari ou madrigaux \&c... (Paris: Chez Choron, 1827-1836?).

Henri Bonaventure Dupont and Georg Falck, Idea boni cantoris (Paris: L'Hauteur, 1718).

François-Joseph Fétis and Thomas Helmore, A treatise on choir and chorus singing (London: Novello, 1854).

Alexis de Garaudé, Nouvelle méthode de chant et de vocalisation ...contenant les préceptes de cet art, 100

exercices pour la voix avec la basse chiffrée, et 25 vocalises ou morceaux de chant sans paroles, avec

accompagnement de piano ou harpe (Paris: Chez l'auteur, au bureau du Journal d'Euterpe, 1809).

Alexis de Garaudé, Solfèges; ou, Novelle méthode de musique (Paris: n.p., 1830s).

Alexis de Garaudé, Méthode complète de chant (Paris: Chez l'auteur., 1826).

Paul-Cesar Gibert, Solfèges, ou Leçons de musique (Paris: n.p., 1769).

Auguste-Mathieu Panseron, ABC musical: dédié aux mères de famille, ou, Solfége: composé tout exprès pour sa petite-fille (Paris: Chez l'auteur, 1890-1899?).

Jean Joseph Rodolphe, Solfège ou Nouvelle méthode de musique (Paris: n.p., 1784).

Guillaume Louis Bocquillon Wilhem, Manuel musical à l'usage des colléges,

des institutions, des écoles et des cours de chant, comprenant, pour tous les modes d'enseignement, le texte et la musique en partition des tableaux de la méthode de lecture musicale et de chant élémentaire par M.B. Wilhem, $2 \mathrm{~d}$ ed., (Paris: Perrotin, 1839).

Giulio Marco Bordogni and Alfred Dörffel, Marco Bordogni [Giulio Marco Bordogni]: Vocalises (3 exercises et 12 vocalises pour Mezzo Soprano ou Bariton). Rev. par Alfred Dörffel (Leipzig: n.p., n.d.).

Alexandre Choron, Méthode concertante de musique à plusieurs parties (Paris: n.p., 1815).

Alexandre Choron, Le musicien pratique (Paris: n.p., 1816).

Alexandre Choron, Exposition élémentaire des principes de la musique (Paris: n.p., 1819).

Alexandre Choron, Cours élémentaire de musique, solfège et chant (Paris: n.p., 1820).

Alexandre Choron, Méthode concertante élémentaire à 3 parties (Paris: n.p., 1820).

Alexandre Choron, Méthode de chant à l'usage des élèves de l'Ecole Royale de Chant (Paris: n.p., 1820).

Alexandre Choron, Journal de musique religieuse (Paris: n.p., 1820).

Alexandre Choron, Journal de chant et d'éducation musicale (Paris: n.p., 1829-1830).

Joseph Mainzer, Singschule (Trier: n.p.,1831). Hans Georg Nägeli and M.T. Pfeiffer, Gesangbildungslehre nach

Pestalozzischen Grundsätzen (Zürich: n.p., 1810).

Hans Georg Nägeli, Vorlesungen über Musik mit Berücksichtigung der Dilettanten (Stuttgart: n.p., 1826).

Alexis de Garaudé, Méthode de chant (Paris: n.p., 1809).

Alexis de Garaudé, Solfège des enfants (Paris: n.p., 1810).

Alexis de Garaudé, 60 solfèges progressifs (Paris: n.p., n.d.).

Alexis de Garaudé, 12 grandes leçons de vocalisation (n.p., c1810).

Alexis de Garaudé, 25 vocalises de Crescentini, op.11 (n.p., c1810).

Alexis de Garaudé, 24 vocalises, op.42 (n.p., n.d.).

Alexis de Garaudé, Méthode de vocalisation, op.65 (n.p., 1854).

Johann Adam Hiller, Musikalisches Handbuch für die Liebhaber des Gesanges und Claviers (Leipzig, n.p., 1773).

Johann Adam Hiller, Anweisung zur Singekunst in der deutschen und italienischen Sprache (Leipzig, n.p., 1773).

Johann Adam Hiller, Anweisung zum musikalisch-richtigen Gesange (Leipzig, n.p., 1774).

Johann Adam Hiller, Exempel-Buch der Anweisung zum Singen (Leipzig, n.p., 1774).

Henri-Philippe Gérard, Méthode de chant (Paris: n.p., 1816-c1825).

Henri-Philippe Gérard, Considérations sur la musique en général et particulièrement sur tout ce qui a rapport à la vocale, avec des observations sur les différents genres de musique, et sur la possibilité d'une prosodie partielle dans la langue française entremêlées et suivies de quelques réflexions ou observations morales (Paris: n.p., 1819).

Jean-Paul-Gilles Martini, Mélopée moderne, ou L’art du chant réduit en principes (Paris: n.p., 1792).

${ }^{69}$ This term is italicized to designate a passage that is virtuoisic in nature.

${ }^{70} \mathrm{NB}$. Il est à remarquer que beaucoup de nos grands violonistes ont adopte diverses manières d'accorder leur violon; en voici quelques exemples:

accord de TARTINI

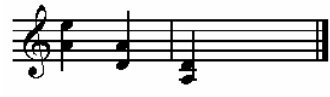

avec cet accord, on a un ton de moins au grave. 
accord de BARBELLA

de moins à l'aigu et au grave.

accord de LOLLI

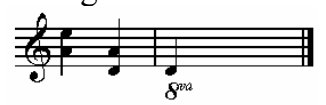

corde baissée de trois tons est trop lâche et ne tient pas l'accord.

accord de PAGANINI

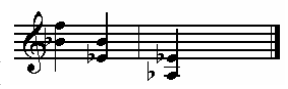

cet accord a une note de plus à l'aigu, et par ce moyen des passages presque inexécutables sur notre accord ordinaire deviennent d'une exécution facile; Paganini accorde quelque fois la $4^{\text {me }}$ corde en $S i b$, ou en $S i$ et il est à remarquer qu'en $S i$ par exemple, le violon est plus sonore; les notes élevées paraissent plus difficiles qu'elles ne le sont réellement; car cette corde étant montée d'une tierce, des passages impraticables sans cela deviennent très faciles à exécuter, mais aussi, en accordant la corde en $S i b$, on a au grave une tierce mineure de moins, et une tierce majeure lorsqu'on l'accorde en Si.

Notre excellent professeur, Mr. BAILLOT, accorde quelque fois la $4^{\text {me }}$ corde en et donne au grave un demi-ton de plus; mais cette corde ne tiendrait pas l'accord si l'effet se prolongeait trop longtems.

Il y a encore une infinité de manières d'accorder le violon; mais nous pensons que ces exemples suffiront pour montrer de combien d'accords différens cet instrument est susceptible. Du reste la meilleure et en même tems la plus simple est sans contredit celle qu’on a adoptée généralement.

Le Guddock ou Gudock est une espèce de violon, (usité chez le peuple Russe), à trois cordes, qu'on fait vibrer au moyen d'un archet; la mélodie se joue sur la première, et les deux autres accordées en quinte, sont presque toujours touchées à vide.

Mr. F. MAZAS a imaginé un mécanisme très simple et très ingénieux pour donner aux instrumens à archet plus de force et une plus belle qualité de son; il fait passer au dessous du chevalet une certaine quantité de petites cordes métalliques, combinées avec les cordes à vide, de manière à obtenir l'accord parfait chaque note de l'échelle. Au moyen d'un petit appareil, ces cordes métalliques sont mises en communication avec l'instrument, ou bien leur effet est annulé, et cela à volonté; ce systême de doubles-cordes peut aussi bien s'appliquer aux violoncelles et contrebasses qu'aux violons.

Nous avons des Méthodes pour le violon de: ANDRÉ, BAILLEUX, BAILLOT, (Méthode adoptée au Conservatoire,) RODE, KREUTZER, GUHR, BLUMENTHAL, CAMPAGNOLI, CAMBINI, VIORELLO, HILLER, LOLLI, Léopold MOZART, (père de notre grand maître,) LOENLEIN, MAZAS, SPOHR, HERZING, ZIMMERMANN de Dresde, WOLDEMAR et autres./

NB. It should be observed that many of our great violinists have adopted various methods of tuning their violins; here are some examples:

TARTINI'S tuning:

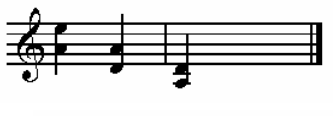

BARBELLA'S tuning: this tuning is soft, and imitates the viola d'amore, but there are two less notes in the high and low registers.

LOLLI'S tuning:

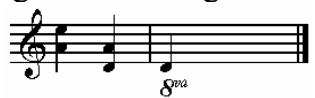

fourth string dropped by three tones is too lax, and does not stay in tune. 
PAGANINI'S tuning: passages which are usually almost impracticable on our normal tuning become easy to execute; Paganini sometimes tunes the fourth string in $\mathrm{A} b$ or in $\mathrm{A}$ and it one should note that in $\mathrm{A}$, for example, the violin is resonant: the high notes seem to be more difficult than they actually are because this chord has gone up a third, passages that were impracticable without Paganini's tuning become very easy to execute, but also because by tuning the string in A $b$ one has a minor third less in the lower register, and a major third when one tunes it in A.

Our excellent professor, Mr. BAILLOT, sometimes tunes the fourth string to: and, moreover, gives the low register an extra semitone; but this string would not stay in tune if the effect were sustained too long.

There is still an infinity of methods for tuning the violin; but we think that these examples are sufficiently demonstrate how many different tunings this instrument is capable of. Moreover, and the simplest and best method is indisputably that which has been generally adopted.

The Guddock or Gudock is a type of violin used by the Russian people that has three strings that one makes vibrate by means of a bow; the melody is played on the first, and the two others, tuned in fifths, are almost always played as open strings.

Mr. F. MAZAS invented a very simple and very clever mechanism which gives the instruments that are played with a bow more force and a more beautiful quality of sound; a certain quantity of small metal strings pass underneath the bridge and combine with the open strings, so that one may obtain the triad of each note on the scale. By means of a small apparatus, these metal strings communicate with the instrument; or one can cancel their effect, as desired; this system of double-strings can be applied to the violoncellos and double basses as well as to the violins.

We have methods for the violin by: ANDRE, BAILLEUX, BAILLOT, (Method adopted with the Academy) GRIND, KREUTZER, GUHR, BLUMENTHAL, CAMPAGNOLI, CAMBINI, VIORELLO, HILLER, LOLLI, Léopold MOZART, (our grand master's father) LOENLEIN, REFINED, SPOHR, HERZING, ZIMMERMANN of Dresden, WOLDEMAR and others.

${ }^{71}$ Johann Anton André, Anleitung zum Violinspielen, op.30 (n.p., 1805).

Antoine Bailleux, Méthode raisonnée pour aprendre à jouër du violon, avec le doigté de ces instrument, et les diférénts agréments dont il ist susceptible (Paris: Chez l'Auteur, 1796).

Pierre Marie François de Sales Baillot, Rodolphe Kreutzer and P. J. J. Rode, Méthode de violon (n.p., 1803).

Pierre Marie François de Sales Baillot, L'art du violon: nouvelle méthode (n.p., 1834).

Karl Wilhelm Fredinand Guhr, L'Art de jouer du violon de Paganini, appendice à toutes les méthodes que ont paru jusqu'à présent avec un traité des sons harmoniques simples et doubles (Paris: Schonenberger, 1831).

Karl Wilhelm Fredinand Guhr, Ueber Paganini's Kunst die Violine zu Spielen

ein Anhang zu jeder bis jetzt erschienenen Violinschule, nebst einer Abhandlung über das Flageoletspiel in einfachen und Doppeltönen; den Heroen der Violine, Rode, Kreutzer, Baillot, Spohr, zugeeignet (Mainz: Schott, 1830).

Bartolomeo Campagnoli, Nouvelle méthode de la mécanique progressive du jeu de violon ... distribuée en 132 leçons progressives pour deux violons, et 118 études pour un violon seul, op.21 (Leipzig: n.p., 1824).

Antonio Lolli, Ecole pour violon (Paris: Sieber fils, n.d.).

Antonio Lolli, L'école du violon en quatuor (Berlin: n.p., c1784).

Johann Georg Leopold Mozart, Versuch einer gründlichen Violinschule (Augsburg: n.p., 1756).

Jacques-Féréol Mazas, L'école du violoniste (Paris: n.p., 1839).

Jacques-Féréol Mazas, L'école du violoniste (Paris: n.p., 1839).

Louis Spohr, Violinschule (Vienna: Haslinger, 1832).

Michel Woldermar, Méthode pour le violon (n.p., 1795-8).

Michel Woldermar, Grande méthode ou Etude élémentaire pour le violon (n.p., 1798-9). 
Michel Woldermar, Barême lyrique de Woldemar, ou L'art de composer toute sorte de musique sans savoir la composition (n.p., 1800).

Giuseppe Tartini, Traité des agrémens de la musique, contenant l'origine de la petite note, sa valeur, la maniere de la placer (Paris: Chés Chevardiere, n.d.).

Nicolò Paganini, Paganini's method of producing the harmonic double stops (n.p.).

${ }^{72}$ Jacob-Joseph-Balthasar Martinn, Méthode élémentaire d'alto (Paris: Frey, 1841

Michel Woldemar, Méthode d'alto (n.p., c1800).

${ }^{73}$ The strings that are indicated are reversed from the number of strings indicated.

${ }^{74}$ NB. Mr. Urban qui joue de cet instrument dans l'opéra les Huguenots (Meyerbeer) l'accorde en Ré, Fa\#, La de la petite octave, Ré, Fa\#, La de la 2 me petite octave; et ainsi en Ré harmoniquement; il emploie aussi la clef d'Ut $3^{\mathrm{e}}$ ligne, pour les notes basses, et la clef de Sol pour les notes élevées; dans le célèbre Romance des Huguenots, il parcourt une étendue de plus de quatre octaves, avec une justesse et une précision merveilleuses. Mr. Urhan a aussi conservé les cordes en cuivre sous celles en boyau.

Manière d'accorder cet instrument de Mr. Urhan:

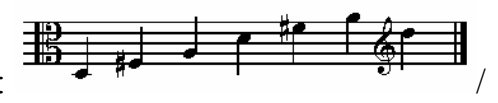

NB. Mr. Urhan, who plays this instrument in the opera The Huguenots (Meyerbeer), tunes it in D, F\#, A of the small octave, D, F \#, A of the second small octave, and thus in D, harmonically; he also uses the C clef, third line, for the bass notes, and the treble clef for the high notes; in the famous 'Romance of the Huguenots', he made use of a range comprising more than four octaves with a marvelous precision. Mr. Urhan also kept the copper strings under the cat-gut strings.

Mr. Urhan's method for tuning this instrument:

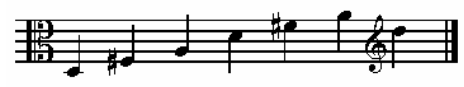

${ }^{75}$ Dans le principe, les violoncelles eurent 5 cordes qui étaient: $U t$, Sol de la grande octave; Ré, La de la petite octave, et Ré de la $2 \mathrm{me}$ petite octave; mais on n'employa cette espèce de violoncelle que pendant quinze ou vingt ans; plus tard on laissa de côté la corde la plus haute, et l'on conserva seulement les quatre plus basses, telles que nous les avons encore aujourd'hui.

Nous avons des Methodes pour le voiloncelle, de BAUDIOT, BAILLOT, AUBERT, AZAIS, BAUMGAEHTNER, CORRETTE, BIDEAU, CATEL, LANZETTA, KAUER, DOTZAUER, LEVASSEUR, MUNBERGER, STIASTNY, CAPIS, PETRI, CHEVILLARD, (Méthode complète qui donne surtout des exercices pour les 17 positions de pouce) BAOUL, DUPORT et autres./

As a rule, the violoncello had five strings which were: $\mathrm{C}$, and $\mathrm{G}$ of the small octave; $\mathrm{D}$ and $\mathrm{A}$ of the great octave; and $\mathrm{D}$ of the second small octave; however, this type of violoncello was only used for fifteen or twenty years; the highest string was later abandoned and only the four lowest strings remained, which we still use today.

We have methods for the violoncello by: BAUDIOT, BAILLOT, AUBERT, AZAIS, BAUMGAEHTNER, CORRETTE, BIDEAU, CATEL, LANZETTA, KAUER, DOTZAUER, LEVASSEUR, MUNBERGER, STIASTNY, CAPIS, PETRI, CHEVILLARD (a very complete method which provides exercises for the 17 thumb positions), BAOUL, DUPORT and others.

${ }^{76} \mathrm{NB}$. On appelle aussi quelquefois cet instrument contra-violon, probablement parceque ses cordes sont justement disposées eu sens inverse de cordes du violon (contra), car les cordes du violon sont d'en bas en haut: Sol, Ré, La, Mi; et celles de la contrebasse, (contra-violon) sont d'en haut en bas: Mi, La Ré. Sol.

Nous avons des Méthodes pour la contrebasse de HANSE, FROELICH, ASIOLI, CORNETTE, MINÉ, DUBIER et autres./ 
NB. This instrument is also sometimes called the contra-violin, probably because its strings are laid out in the exact opposite direction as are the strings of the violin (contra), for the violin's strings are, from bottom to top: G, D, A, E and the double bass's (contra-violin) strings are, from top to bottom: E, A, D, G.

We have methods for the double bass by: HANSE, FROELICH, ASIOLI, CORNETTE, MINÉ, DUBIER and others.

${ }^{77}$ Franz Joseph Fröhlich, Kontrabass-Schule (Würzburg: n.p., 1829).

Michel Corrette, Méthode pour apprendre à jouer de la contre-basse à 3, à 4, et à 5 cordes (Paris: n.p., 1773).

${ }^{78}$ NB. Dans les morceaux en $F a$ ou ne $S i b$, on accorde quelquefois la corde la plus grave en $F a$, afin de n'avoir pas besoin d'employer le pouce de la main gauche pour prendre ce ton.

La guitare d'amour est une modification de la guitare ordinaire, mais assez peu répandue; elle est accordée comme celle-ci, mais elle se touche avec un archet et non point pizzicato.

En France on fabrique depuis 1820, des guitares en forme de lyre qu'on appelle: Lyre ou Guitare; quant aux cordes et à l'exécution elles étaient absolument les mêmes que pour la guitare ordinaire.

La lyre est un des plus anciens instrumens; elle n'avait dans le principe que trois cordes' puis elle ne eut sept; et enfin jusqu'à douze; sa forme est tellement connue qu'il est inutile d'en donner une description./

NB. In pieces in $\mathrm{F}$ or $\mathrm{A} b$, one sometimes tunes the lowest string in $\mathrm{F}$, so that one does not need to employ the thumb of the left hand to play this key.

The guitar d'amore is a modification of the ordinary guitar, but its use is not very widespread; it is tuned like an ordinary guitar, but one plays it with a bow and not pizzicato.

Guitars in the shaped of a lyre have been manufactured in France since 1820; they are called: lyre or guitar; as for the strings and the instrument's performance: they were just the same as for the ordinary guitar.

The lyre is one of oldest the instruments; as a rule it only had three strung, then four strings were added to make seven, and the instrument had, finally, twelve strings; its shape is so well known that it is useless to give a description of it.

${ }^{79}$ La guitare dérive d'un instrument nommé Cithre (Kidara Cithara;) tantôt on pinçait le cithre avec les doigts, tantôt on le frappait avec une petite baguette appelée l'lectrum. Il y en avait de plusieurs espèces, par exemple: de 4, 5, 6, et même jusqu'à 12 chœurs de cordes; par chœur de cordes on entendait deux cordes à l'unisson, ainsi, un cithre à 6 chœurs de cordes avait 12 cordes.

Le cithre à 4 chœurs, (8 cordes,) s'appelait cithre discant: 1'accord était:

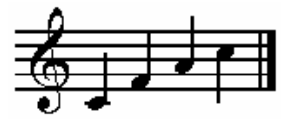

En dessous du manche se trouvaient encore 8 cordes libres qui formaient la basse et qui s'accordaient en $S i b, U t, R e ́$,

Mi, Fa, Sol, La, Sib,

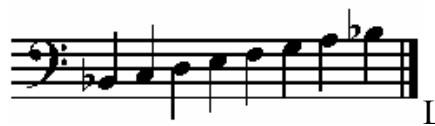

Le cithre à 5 chœurs, (10 cordes,) qu'on appelait cithre ténor, 


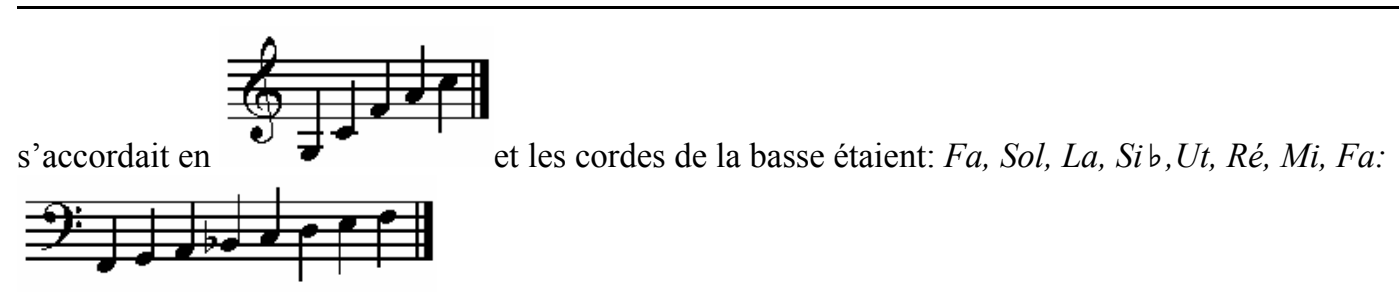

Le cithre à 6 chœurs, (12 cordes,) qui était le plus ordimaire, s'accordait en Sol, Ré, Sol, Si, Ré, La:

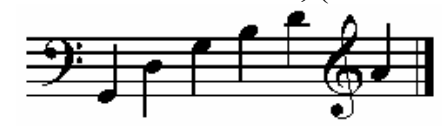

Il existait encore une autre espèce de cithre plus petit qui n'avait que quatre cordes; ces cordes se pinçaient au moyen d'un bec de plume ou d'une petite baleine.

De tontes ces espèces, aucune n'est usitée; on ne les trouve plus qu'entre les mains des vagabonds et des montagnards qui s'en servent pour accompagner leurs chants./

The guitar was derived from an instrument called the Cithre (Kidara, Cithara); sometimes one plucked the strings with the fingers, and sometimes one used a small rod called the plectrum. There were several types, for example: of $4,5,6$, and up to 12 choruses of strings, by using choruses of strings, one tuned two strings in unison; thus, a cither with 6 choruses of strings had 12 strings.

The four-chorus cither ( 8 strings) was called the discant cither; its range was:

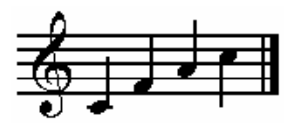

Below the handle were another 8 free strings, which formed the bass and were tuned to B b, C, D, E, F, G, A, and

$\mathrm{B} b$,

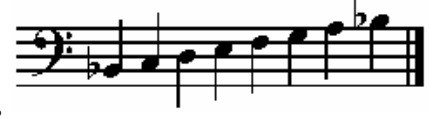

The 5-chorus cither( 10 strings), which was called the tenor cither, was tuned in

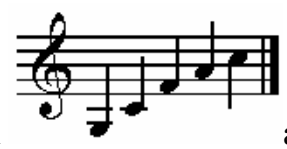

and the bass

strings were: F, G, A, B b, C, D, E, F:

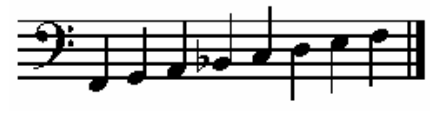

The 6 chorus cither (12 strings), which was the most common, was tuned to G, D, G, B, D, A.

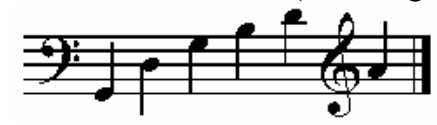

There also existed one other type of much smaller cither that only had four strings; these strings were plucked with a feather or a small whale bone.

None of the types described above are used today; one finds the instrument in the hands of vagrants and mountain dwellers that use it to accompany their voices. ${ }^{80}$ Nous avons des Méthodes pour la guitare de DOISY, CARULLI, BORNHARDT, BEROLAZZI, MOLINO,
GUILIANI, SOR, LEHMANN, WOLFAHRT, AGUADO, BAILLON, CARCASSI et autres./ 
We have methods for the guitar by DOISY, CARULLI, BORNHARDT, BEROLAZZI, MOLINO, GUILIANI, SOR, LEHMANN, WOLFAHRT, AGUADO, BAILLON, CARCASSI and others.

${ }^{81}$ Fredinando Carulli, Méthode complète (n.p., 1825).

Fredinando Carulli, L'harmonie appliquée à la guitare (n.p., 1825).

Johann Heinrich Carl Bornhardt, Anweisung die Guitarre zu spielen: nebst einigen Uebungen und Handstücken auch einer Anleitung selbige bequem zu stimmen (Hamburg: Böhm, 1830).

Francesco Molino, Grande méthode complette pour la guitare (Paris: n.p., 1800-1899?).

Mauro Guiliani, Studi, op. 111, per chitarra (Ancona: Edizioni musicali, 1970).

Mauro Guiliani, Metodo per chitarra (Ancona: Edizioni musicali, 1964).

Mauro Guiliani, 24 Studien für Gitarre, op. 100 (Mainz: Schott's, 1929).

Mauro Guiliani, 120 daily guitar studies for the right hand (New York: Celesta, 1949).

Frenando Sor, Méthode pour la guitare (Paris: Lachevardiere, 1830).

Dionisio Aguado y Garcia, Nuevo metodo para guitarra (Madrid: n.p., 1843).

Dionisio Aguado y Garcia, Colección de estudios para guitarra (Madrid: n.p., 1820).

Dionisio Aguado y Garcia, Escuela de guitarra (Madrid: n.p., 1825).

Matteo Carcassi, Metodo completo para guitarra, ed. Eduardo de Albistur, (Buenos Aires: Ricordi Americana, 1936).

${ }^{82}$ Matteo Carcassi, Metodo completo para guitarra, ed. Eduardo de Albistur, (Buenos Aires: Ricordi Americana, 1936).

${ }^{83} \mathrm{NB}$ Il est à présumer que les premiers luths furent faits en écaille de tortue./

${ }^{\mathrm{NB}}$ It is presumed that the first lutes were made from the shell of a turtle.

${ }^{84}$ Cette manière d'écrire si extraordinaire se nomme tablature de luth; les joueurs de luth la conservèrent avec un entêtement ridicule et ne voulurent jamais accepter notre manière de noter qui est pourtant beaucoup plus brève et plus commode.

En Italie on imagina, en 1509, d'employer des chiffres au lieu de lettres pour désigner les différens degrés./ This extraordinary notation method is called lute tablature; lute players have, with ridiculous stubbornness, continued to use it, refusing to accept our method of notation, which is much shorter and more practical.

It was in Italy, in 1509 , that a system of notation was invented that used figures rather than letters to designate the different degrees.

${ }^{85}$ Nous avons des Méthodes pour le luth de PETRUCCI, (Venise 1509) PERRINE et autres.

Le calascione ou colascione est un instrument à cordes usité dans l'Italie inférieure.

Il a un petit corps de luth, mais seulement avec deux faibles cordes à boyau qu'on pince avec les doigts ou bien avec une écorce d'arbre très mince; ces deux cordes font une quinte.

Le calichon est un ancien instrument à cordes en forme de luth; il avait cinq cordes accordées

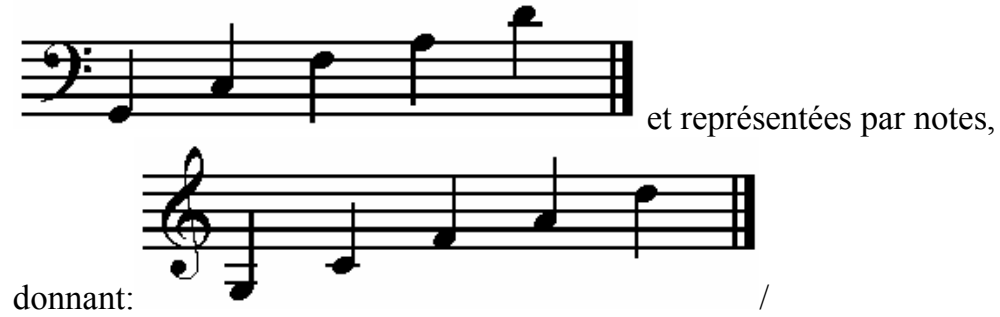

We have methods for the lute of PETRUCCI, (Venice, 1509) PERRINE and others. 
The calascione or colascione is a string instrument used in southern Italy.

It has a small body like that of the lute, but with only two weak gut strings that are gripped with the fingers or with piece of very thin tree bark; these two strings form a fifth.

The calichon is an old string instrument in the shape of a lute; it has five strings tuned in:

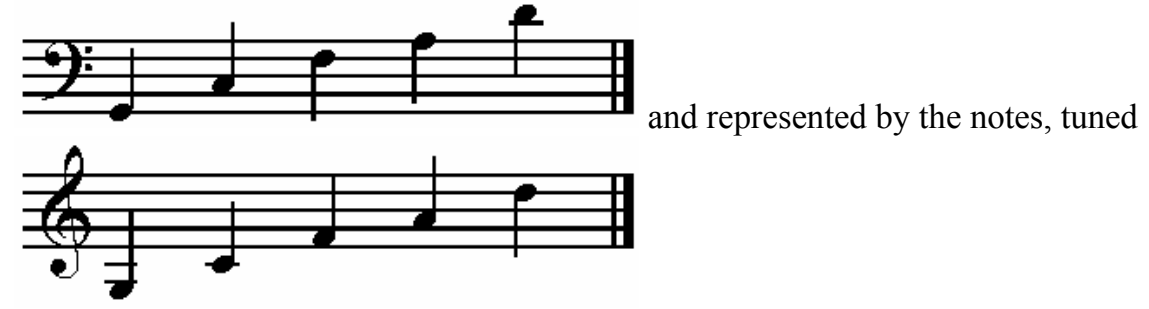

${ }^{86}$ Perrine, Livre de musique pour le lut, contenant une metode nouvelle et facile pour aprendre à toucher le lut sur les notes de la musique (Paris: n.p., 1679).

Perrine, Et une table pour aprendre à toucher le lut sur la basse continüe pour accompagner la voix (Paris: n.p., 1682).

Perrine, Pieces de luth en musique avec des regles pour les toucher parfaitement sur le luth et sur le clavessin (Paris: n.p., 1680).

${ }^{87}$ On fabriquait des luths de diverses grandeurs, ce qui donna naissance à plusieurs instrumens nouveaux, mais qui néanmoins faisaient toujours partie de la même famille.

Il y avait encore une espèce de luth nommé pandurine, ou mandurine, qui n'avait que quatre cordes; ces cordes étaient accordées en cet instrument servait à accompagner le chant./

Lutes were made in many sizes; these gave birth to many new instruments, but which nevertheless remained in the same family.

There was also a type of lute named the pandurine or mandurine, which only had four strings which were tuned to accompany voices.

${ }^{88}$ Allessandro Piccinini, Intavolatura di liuto, et di chitarrone, libro primo (Bologne, 1623).

${ }^{89}$ Bartholomeo Bortolazzi, Anweisung' die Mandoline von selbst zu erlernen (Leipzig: n.p., 1805).

Giovanni Fouchetti, Méthode pour apprendre facilement à jouer de la mandoline à 4 et à 6 cordes (Paris: n.p., 1771).

${ }^{90}$ Philippe-Jacques Meyer, Essai sur la vraie manière de jouer de la harpe, avec une méthode de l'accorder, op.1 (Paris: n.p., 1763).

Philippe-Jacques Meyer, Nouvelle méthode pour aprendre à jouer de la harpe avec la manière de l'accorder, op.9 (Paris: n.p., 1774).

Robert Nicholas Charles Bochsa, 12 leçons élémentaires, op.16 (n.p., n.d.).

Robert Nicholas Charles Bochsa, Méthode de harpe en 2 parties, op.60 (n.p., n.d.).

Robert Nicholas Charles Bochsa, Petite méthode pour la harpe ... à l'usage des jeunes élèves, op.61 (n.p., c1830).

Robert Nicholas Charles Bochsa, Bochsa's Explanation of his New Harp Effects and Passages (London, n.p., 1832).

Robert Nicholas Charles Bochsa, The Harp Preludist ... 16 Lessons (London, n.p., 1832?).

Johann Georg Heinrich Backofen, Harfenschule: mit Bemerkungen über den Bau der Harfe und deren neuere

Verbesserungen (Leipzig: Breitkopf und Härtel, 1800-1899?).

Henri Pascal Naderman, Observations sur la harpe à double mouvement, ou Réponse à la note de M. Prony (Paris, n.p., 1815). 
Henri Pascal Naderman, Réfutation de ce qui a été dit en faveur des différents mécanismes de la harpe à double mouvement, ou Lettre à M. Fétis en réponse (Paris, n.p., 1828).

Henri Pascal Naderman, Supplement à la réfutation (Paris, n.p., 1829).

Xavier Désargus, Traité complet et raisonné, compose pour l'enseignement des harpes à simple et à double mouvement (Paris: Chez l'auteur et chez A. Petit, 1809).

Xavier Désargus, Cours complet de harpe, redigée sur le plan de la méthode de piano du Conservatoire (Paris: n.p., 1816).

${ }^{91}$ On appelle pedale l'extrèmité inferieure du mécanisme qui agit sur les cordes en raccourcit la partie vibrante et les élève d'un demi-ton./

The pedal is the extremity below the mechanism which shortens the strings, raising the notes one half-step.

${ }^{92}$ L'ancienne harpe en Mib étant encore généralement usitée dans nos orchestras, il est mieux de composer pour elle, jusqu'à ce qu'on ait tout-à-fait adopté la nouvelle espèce en Utb

Le psaltérion était une sorte de harpe carrée, portant 10 cordes et même quelquefois plus; on la jouait avec une baguette./

Because the old harp in $\mathrm{E} b$ is used more often in our orchestras, it is better to compose for it, until the new type in $\mathrm{Cb}$ is more generally accepted.

The psaltery was a kind of harp with ten strings, and sometimes more. It was played with a plectrum.

${ }^{93} \mathrm{Il}$ y a encore plusieurs autres manières de construire la harpe d'Eole, mais l'effet est toujours le même./ There are still several other ways of constructing the Aeolian harp, but the effect is always the same.

${ }^{94}$ La vielle. L'étendue de cet instrument, que l'on ne rencontre plus de nos jours que dans les rues, va: du Sol de la

$2^{\mathrm{e}}$ petite octave jusqu'au $\mathrm{Sol}$ de la $4^{\mathrm{e}}$ petite octave:

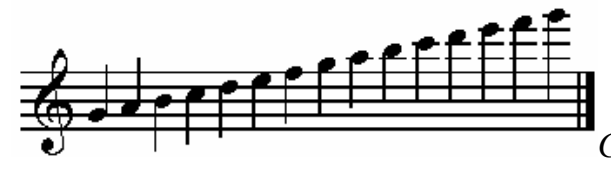

La vielle est, comme on sait, munie d'un clavier qui permet d'y exécuter des morceaux assez compliqués, mais le son n'en demeure pas moins toujours criard, et désagréable./

The hurdy-gurdy. The range of this instrument, that nowadays is only found on the streets, goes from $\mathrm{G}$ of the

second small octave to $\mathrm{G}$ of the fourth small octave:

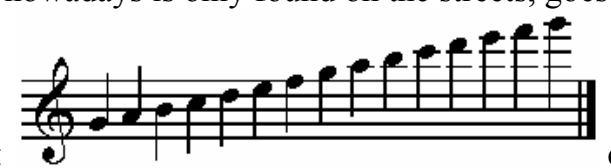

chromatically.

The hurdy gurdy is, as is commonly known, furnished with a keyboard which makes it possible to play rather complicated pieces, but the tone is no less garish or disagreeable.

${ }^{95}$ Pierre-Jean Lambert, Pièces de clavecin (Paris: Chez l'Auteur, 1750).

Carl Philipp Emanuel Bach, Versuch über die wahre Art das Clavier zu spielen, $i$ (Berlin: n.p., 1753).

Ferdinand Kauer, Klavier Schule (n.p.: J. Eder, 1803).

Daniel Gottlob Türk, Clavierschule, oder Anweisung zum Clavierspielen für Lehrer und Lernende ... nebst 12

Handstücken (Leipzig: n.p., 1789).

Daniel Gottlob Türk, Kurze Anweisung zum Klavierspielen: ein Auszug aus der grössern Clavierschule (Leipzig: n.p., 1792).

Jan Ladislav Dussek, Instructions on the Art of Playing the Piano Forte or Harpsichord (London: n.p., 1796). 
${ }^{96}$ Ces piano se trouvent rependant rarement; les essais n'ont pas eu de succès, parceque les cordes des notes aigues, etant trop courtes, produisent une mauvaise résonnance./

These pianos are, however, seldom used, for the tests have been unsuccessful because the high notes, being too short, resonate badly.

${ }^{97}$ Louis Adam, Méthode de piano (Genève: Minkoff, 1805).

Muzio Clementi, Introduction to the art of playing on the piano forte (n.p., 1801).

Muzio Clementi, Gradus ad Parnassum, or The Art of Playing on the Piano Forte (Leipzig: n.p., 1817-26).

Johann Baptist Cramer, Studio per il pianoforte (n.p., 1804-10).

Johann Baptist Cramer, Instructions for the Pianoforte (n.p., 1812).

Johann Baptist Cramer, Dulce et utile, op.55 (n.p., 1815).

Johann Baptist Cramer, 25 New and Characteristic Diversions (n.p., 1825).

Johann Baptist Cramer, New Practical School, op.100 (n.p., 1844).

Carl Philipp Emanuel Bach, Versuch über die wahre Art das Clavier zu spielen, $i$ (Berlin: n.p., 1753).

Auguste Bertini, Bertini's Self-Teaching Catechism of Music for the Piano Forte (London: n.p., 1855).

Charles Chaulieu, L'indispensable op.100 (Paris: n.p., 1830).

Charles Chaulieu, 63 études spéciales op.130 (Paris: n.p., 1832).

Carl Czerny, Fantasie-Schule, $i$ : Systematische Anleitung zum Fantasieren auf dem Pianoforte, op.200 (Vienna, n.p., 1829).

Carl Czerny, Die Schule des Fugenspiels und des Vortrags mehrstimmiger Sätze und deren besonderer

Schwierigkeiten auf dem Piano-Forte in 24 grossen Übungen, op. 400 (Vienna, n.p., 1836?).

Ignace Joseph Pleyel, 27 instructional exercises published in a piano forte method (n.p., 1796).

Jan Ladislav Dussek, Instructions on the Art of Playing the Piano Forte or Harpsichord (London: n.p., 1796).

Bernard Viguerie, L'art de toucher le piano-forte, ou méthode facile (n.p.,1795).

Johann Nepomuk Hummel, Ausführlich theoretisch-practische Anweisung zum Piano-forte Spiel (Vienna: n.p., 1828).

Daniel Steibelt, Méthode de pianoforte (n.p.,1805).

Frédéric Kalkbrenner, Méthode pour apprendre le piano-forte à l'aide du guide-mains, op.108 (n.p., 1831).

Frédéric Kalkbrenner, Traité d'harmonie du pianiste, op.185 (Paris:n.p., 1849).

Daniel Gottlob Türk, 120 Handstücke für angehende Klavierspieler (Leipzig: n.p., 1792).

${ }^{98}$ De nos jours on a tenté, (surtout en Allemagne,) de donner à l'orgue toute la perfection possible par un registre de crescendo et de decrescendo; on y a même ajouté des cloches et un jeu d'acier. Les frères BERNHARDT, facteurs d'orgues à Romrard, en Hesse, ont invente un mécanisme au moyen duquel on peut hausser, ou baisser à volonté le ton de tout le clavier de l'orgue./

Nowadays one has tried (especially in Germany), to give the organ all possible perfection by access to a crescendo and decrescendo registers; bells and a steel plate were even added. The brothers BERNHARDT, organ builders in Romrard, in Hesse, have invented a mechanism that can raise or lower the pitch of all the keyboards of the organ, as desired.

${ }^{99}$ On a fait une imitation de ces pédales en ajoutant des pédales à un forté-piano, afin que les artistes, à défant d'orgue, pussent s'exercer au jeu des pieds; mais dans le piano ces pédales aboutissent à des cordes, et dans l'orgue elles aboutissent aux plus grands tuvaux./

An imitation of these pedals was added to a piano, so that those musicians lacing an organ could practice their pedaling technique, but on the piano these pedals ended at the strings, and on the organ they end at the largest pipes.

${ }^{100}$ Georg Christian Friedrich Schlimbach, Ueber die Structur, Erhaltung, Stimmung, Prüfung u. der Orgel (Leipzig: Breitkopf, 1801).

Johann Heinrich Zang, Der vollkommene Orgelmacher oder Lehre von der Orgel und Windprobe (Nuremberg: n.p., 1804).

Carl Ferdinand Becker, Systematisch-chronologische Darstellung der musikalischen Literatur von der frühesten bis auf die neueste Zeit (Leipzig: n.p. 1836). 
Johann Gottlob Schneider, Evangelisches Kirchenpräludienbuch, zugleich ein nothwendiges Lehr- und Lernbuch für den Orgelunterricht in Schullehrer-Seminarien (Dresden: n.p., 1810-1864?).

${ }^{101}$ Jean-Paul-Gilles Martini, Ecole d'orgue, divisée en trois parties (Paris: n.p., c1805).

Daniel Gottlob Türk, Von den wichtigsten Pflichten eines Organisten in Beytrag zur Verbesserung der musikalischen Liturgie (Halle: n.p., 1787).

Guillaume Lasceux, Journal de pièces d'orgue, contenant des messes, Magnificat et noëls (n.p., 1771-2).

Johann Friedrich Wilhelm Sonnenkalb, Kurtze Entscheidung der Frage: wie sollen die praeludia eines Organisten bey dem Gottesdienste beschaffen seyn? Oder: welches sind die Kennzeichen eines in seinen Amts-Verrichtungen verständigen Organisten? (Torgau: Johann Gottlieb Petersell, 1756).

Georg Joseph Vogler, Organist-schola (Stockholm: n.p., 1798-9).

Georg Joseph Vogler, Simplifikazions-System für den Orgelbau (Stockholm: n.p., 1798-9).

${ }^{102} \mathrm{Si}$ on veut représenter en notes tous les tons d'un orgue dont le tuyau le plus grave a 32 pieds et le tuyau le plus

élevé 2 pieds, et dont le clavier n'a que quatre octaves; par exemple:

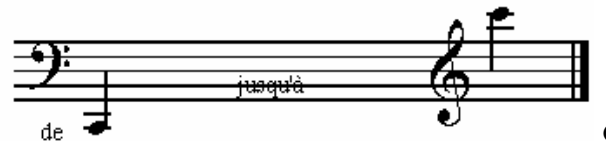

obtient la succession suivante:

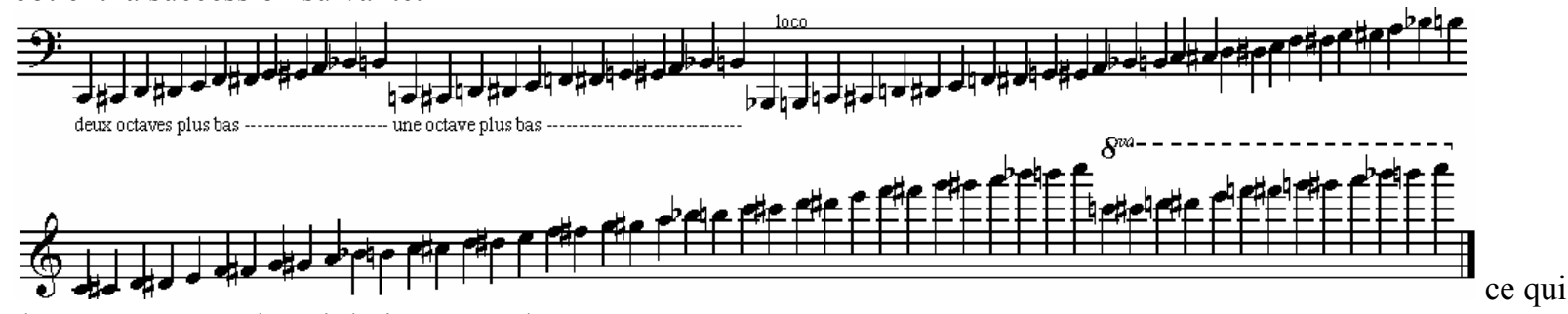

donne comme on le voit huit octaves./

If one wishes to represent, in notes, the range of the organ whose lowest pipe is thirty-two feet long, to the highest,

two feet long, and whose keyboard has only four octaves, for example:

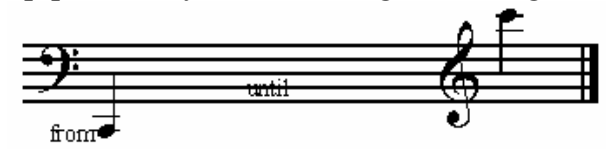

one obtains the following succession:
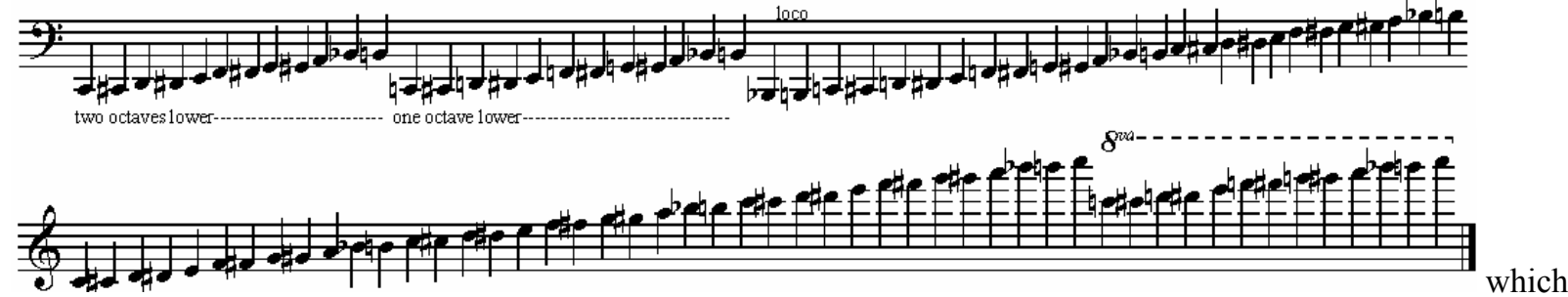

produces, as one can see, eight octaves.

${ }^{103}$ L'eolicorde est un instrument à clavier dont les tous ont beaucoup d'analogue avec ceux du cornet à pistons et généralement de tous les instrumens à vent en cuivre.

Le clavier est identique à celui de piano; l'air se communique au mécanismes de l'instruments au moyen d'un soulflet.

L'etendue du clavier de l'eulicorde est:

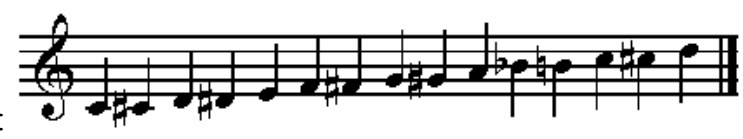

A l'aide d'une vis qu'on hausse ou qu'on abaisse l'instrument se transpose dans d'autres tons à volonté./

The eolicorde is a keyboard instrument which has much in common with the valved cornet, and generally with all the brass instruments. 
The keyboard is identical to a piano keyboard; the air is moved through the mechanisms of the instrument by means of a bellows.

The range of the eolicorde's keyboard is:

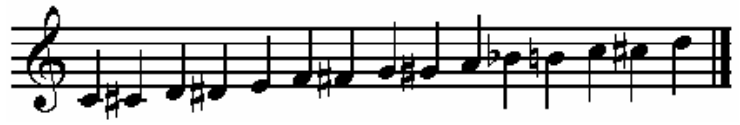

A screw is used to raise or lower the instrument and thus change keys as desired.

${ }^{104}$ On a en Russe une sorte d'harmonica en bois et paille récemment perfectionné par Mr. Gusikovv on le joue comme l'harmonica de verre avec deux petites baguettes, et ainsi on ne peut produire que deux tons à la fois; son étendue est à que près de deux octaves et demie./

In Russia, there is a type of harmonica constructed in wood and straw that was recently perfected by Mr. Gusikovv; it is played with two small sticks like a glass harmonica; thus only two keys can produced at once. The range of this type of harmonica is approximately two and a half octaves.

${ }^{105}$ Johann Christian Müller, Anleitung zum Selbstunterricht auf der Harmonika (Leipzig: Crusius, 1788).

${ }^{106}$ Aristide Cavaillé-Coll, “Le poïkilorgue”, Bulletin trimestriel des amis de l’orgue, no.7 (1931): 4.

${ }^{107}$ La flûte fut d'abord enrichie de beaucoup de clefs, par QUANZ et plus tard par TromLITZ et autres, ce qui fit surmonter de grandes difficultés; M. ${ }^{\mathbf{r}}$ Ant: BEYR Professor an Conservatoire de Vienne a fait faire une flûte nommée Panaylon qui produit encore conq fons plus bas, ce qui peut aussi la faire appeler flûte en $\mathrm{Sol}$; pour faciliter l'exécution de tous les passages les plus difficiles et autrefois inexécutables, elle est munie de quinze clefs et elle a une étendue du $\mathrm{Sol}$ de la petite octave à l'Ut de la $5 .^{\mathrm{e}}$ petite octave:

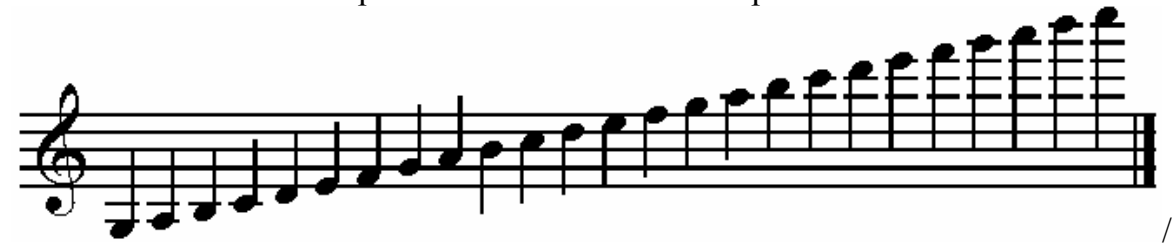

The flute was initially furnished with keys (which made it possible to overcome great difficulties) by QuANZ, and later by Tromlitz and others. Mr. A. BEYR, Professor at the Vienna Conservatory, had a flute, called a Panaylon, made that produces five lower keys, for this reason one can also call this flute the Flute in G; in order to facilitate the execution of the most difficult and (formerly) impracticable passages, it is equipped with fifteen keys and has a range from $\mathrm{G}$ of the small octave to $\mathrm{C}$ of the fifth small octave:

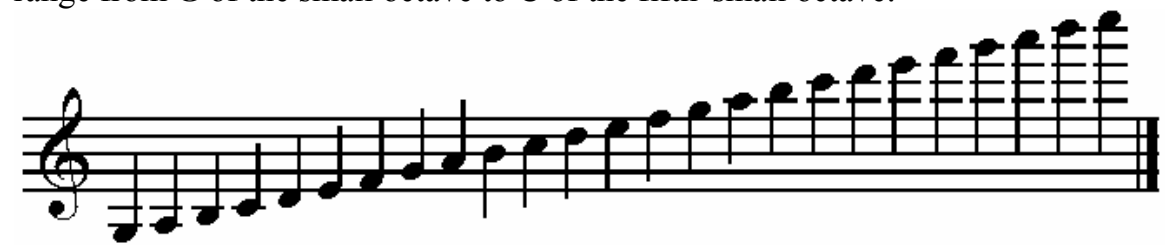

${ }^{108}$ Johann Joachim Quanz, Versuch einer Anweisung die Flöte traversiere zu spielen (Berlin: n.p., 1752). Johann George Tromlitz, Kurze Abhandlung vom Flötenspielen (Leipzig: n.p., 1786). Johann George Tromlitz, Ausführlicher und gründlicher Unterricht die Flöte zu spielen (Leipzig: n.p., 1791). Johann George Tromlitz, An das musikalische Publikum (Leipzig: n.p., 1796). Johann George Tromlitz, Über die Flöten mit mehrern Klappen (Leipzig: n.p., 1800). Johann George Tromlitz, Fingerordnung für meine Flöten zu 3, 5 und 7 Mittelstück und 1, 2, 3, 4, 5 und 6 Klappen, nebst dem Gebrauch des Register und abgetheilte Propfschraube (Leipzig: n.p., n.d.). Georg Bayr, Practische Flöten-Schule (Vienna: n.p., 1823).

${ }^{109}$ Pour la rareté du fait, il faut observer que cet artiste est parvenu à produire des sons doubles, tells que tierces, quartes sixtes, $\&^{\text {it }}$ qui dans les tons doux comme $M i b, L a b$, Réb, sont d'un effet vraiment aérien. 
Le calandrone est un instrument à vent en usage chez les habitans de la campagne en Italie; it est fore de plusieurs trous comme la flûte et à l'extrémité inférieure sont fixées deux clefs, qui lorsqu'elles sont pressées, laissent échapper le son par deux ouvertures différentes./

Due to the rarity of the fact, it should be observed that this artist managed to produce double sounds, such as thirds, fourths, and sixths, and the like, which in the softer keys suck as $\mathrm{E} b, \mathrm{~A} b, \mathrm{D} b$, produces a very airy effect.

The calandrone is a wind instrument that is quite useful to the inhabitants of the Italian countryside; like the flute it has several drilled holes, and two keys are affixed at the lower end, which allow the sound to escape through two different openings when they are pressed.

${ }^{110}$ Georg Bayr, Practische Flöten-Schule (Vienna: n.p., 1823).

Antoine Benoît Tranquille Berbiguier, Nouvelle méthode pour la flûte (Paris: n.p., c1818).

François Devienne, Nouvelle méthode théorique et pratique pour la flûte (Paris: n.p., 1794).

Louis-François-Philippe Drouet, Méthode pour la flûte (Antwerp: n.p., c1827).

Moritz Furstenau, Flöten-Schule (Leipzig: n.p., c1826).

Moritz Furstenau, Die Kunst des Flötenspiels (Leipzig: n.p., 1844).

Antoine Hugot, Méthode de flûte du Conservatoire (n.p., 1804).

Jean-Georges Wunderlich, Méthode de flûte du Conservatoire (n.p., 1804).

Jean-Georges Wunderlich, Principes élémentaires et gradués pour la flûte (n.p., c1815).

A.E. Müller, Elementarbuch für Flötenspieler (Leipzig: n.p., c1815).

Amand Vanderhagen, Nouvelle méthode de flute (Paris: n.p., 1790).

Giuseppe Maria Cambini, Méthode pour la flûte traversière suivie de vingt petits airs connus et six duo à l'usage des commençans (Paris: n.p.,1799).

Jean-Louis Tulou, Méthode de flûte progressive et raisonnée adoptée par la comité d'enseignement du Conservatoire (Mainz: n.p., 1835).

Eugène Walckiers, Methode de flûte (Paris: Chez l'Auteur, 1850).

${ }^{111}$ William Bainbridge, Observations on the cause of imperfections in wind instruments, particularly in German flutes with remarks on the embouchure, or mouth-hole, and other parts of the instrument, which are frequently made out of proportion, and consequently the cause of many amateurs playing imperfectly: also, remarks on oboe, clarionet, and bassoon reeds: with directions how to select them, and keep them in order: thereby rendering those instruments not so difficult to learn, as they have often been considered (London: Innes, 1823).

${ }^{112} \mathrm{Au}$ moyen de toutes les clefs aujourd'hui adaptées au hautbois, on a réussi à surmonter presque toutes les difficultés, et l'étendue du nouveau hautbois est maintenant:

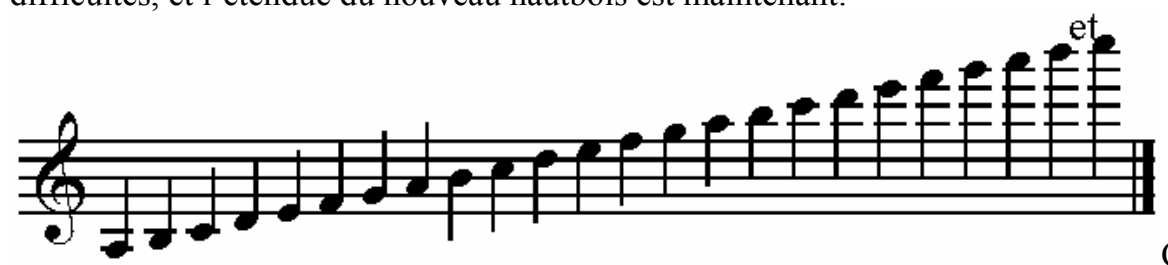

déjà été dit plus haut, on ne peut se servir dans l'orchestre ni des tons les plus élevé hautbois perfectionnes n'étant pas encore connus partout.

Autrefois on se servait aussi du hautbois dans la musique militaire, mais peu à peu cela a passé de mode, on ne le trouve plus aujourd'hui que dans la musique militaire Allemande.

On avait jadis des hautbois de diverses grandeurs qui correspondaient aux quatre voix humaines.

Le premier qui désignait notre hautbois actuel s'appelait oboe piccolo. 
Le moyen s'appelait oboe d'amore, ou oboe luongo, il différait du premier $1 .^{\circ}$ en ce que son timbre était plus faible et plus agréable $2 .^{\circ}$ en ce qu'il était une tierce plus bas et s'étendait du $L a$ de la petite octave aulieu de l' $U t$ de la $2 .^{\text {e }}$ petite octave, jusqu'au $S i$ de la 3. ${ }^{\mathrm{e}}$ petite octave.

En la $3^{\mathrm{e}}$ espèce était l'oboe basso ou grand hautbois duquel est probablement dérivé le basson, ou qui du moins à été remplacé par ce dernier instrument./

By using the keys which affixed to the oboe, one has been able to overcome almost all difficulties, and the new

range of the oboe is now:

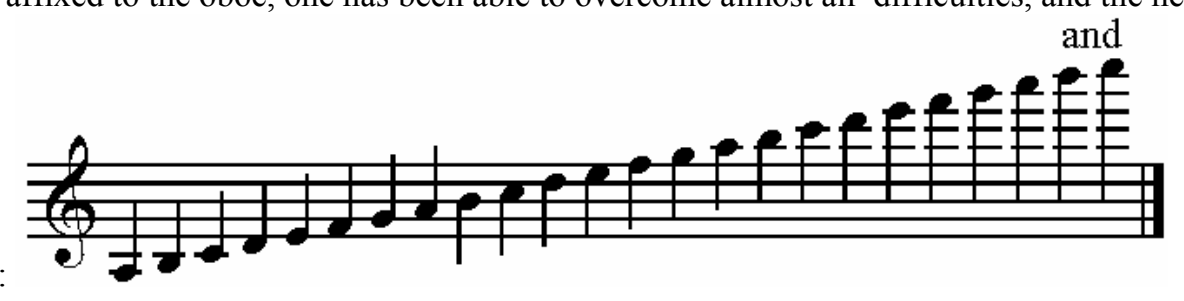

chromatically, but as was previously stated, one uses neither the highest nor the lowest tones in the orchestra, because these improved oboes are not yet generally known.

Formerly, the oboe was used in military music, but little by little that passed from fashion. Today one finds it in only in German military music.

There were, formerly, three oboes of various sizes that corresponded to the four human voices.

The first, which corresponds to our modern oboe, was called oboe piccolo

The middle was called the oboe d'amore, or oboe luongo, it differed from the oboe thusly: first, in that its timbre was weaker and more pleasant; second, in that it was a third lower and its range extended from the A of the small octave (instead of the $\mathrm{C}$ of the second small octave) up to $\mathrm{B}$ of the third small octave.

The third type was the oboe basso or large oboe, which was probably derived from the bassoon, or at least was replaced by this instrument.

${ }^{113}$ Henri Brod, Méthode pour le hautbois (Paris: n.p., 1825-35).

Francois-Joseph Garnier, Méthode raisonnée pour le haut-bois (Paris: n.p., 1802).

Johann Christian Schickhardt, Compleat Tutor to the Hautboy (London: n.p., 1715).

J. Sellner, Theoretisch-praktische Oboeschule (Vienna: n.p., 1825).

Amand Jean François Joseph Vanderhagen, Méthode nouvelle et raisonée pour le hautbois (Paris: n.p., 1792).

J. Fröhlich, Hoboeschule nach den Grundsätzen der besten über dieses Instrument bereits erschienenen Schriften (Bonn: n.p., 1810).

${ }^{114}$ Le Biniou est une espèce de cornemuse particulière en usage chex les paysans Bas-Bretons, ainsi que dans le Comté de Cornouaille et le pays de Galles./

The biniou is a type of cornemuse used by the peasants of southern Brittany, as well as in the county of Cornwall and in Wales.

${ }^{115}$ Un des plus grands maîtres sur cet instrument, était Philippe TEIMER à Vienne, et les trois frères Hofmeister, dont l'un, E. A. Hofmeister, composait expressément des trios sur cet instrument pour lui et ses deux frères./

One of the greatest masters of this instrument was Philippe Teimer of Vienna and the three Brothers Hofmeister, one of whom, E.A. Hofmeister, composed trios on this instrument for himself and his two brothers.

${ }^{116}$ Etienne Ozi, Méthode de basson ... avec des airs et des duos (n.p.,1788).

Etienne Ozi, Méthode nouvelle et raisonnée pour le basson (n.p.,1787).

Etienne Ozi, Nouvelle méthode de basson adoptée par le Conservatoire (n.p.,1803). 
J. Fröhlich, Vollständige theoretisch-praktische Musikschule für alle beym Orchester gebräuchliche wichtigere Instrumente (Bonn: n.p., 1810-11).

Carl Almenraeder, Fagottschule/Méthode complète de basson (Mainz: n.p., 1843).

${ }^{117}$ On peut encore donner

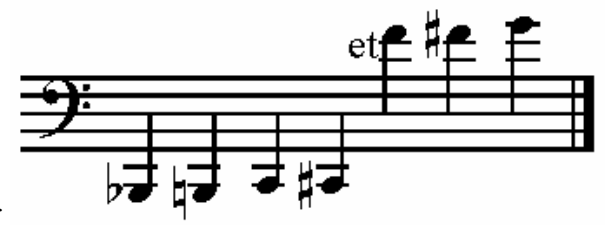

difficiles à intonner, c'est pourquoi il faut s'abstenir de les employer.

mais avec peine, car ces notes sont très

On a encore un basson quarte qui est une quarte plus bas que le basson ordinaire, et un autre, mais cependant plus rarè et qu'on appelle basson ténor (en Italien fagottino) il est une quinte plus élevé que le basson ordinaire.

Quant à la manière de s'en servir, toutes ces espèces de bassons ressemblent au basson ordinaire et la seule différence consiste dans le ton. On ne les emploie jamais dans l'orchestre, et ils ne se trouvent plus que rarement dans la musique militaire Allemande.

Il est à remarquer que le hautbois, le cor anglais, le basson et le contrebasson ne forment qu'une seule et même famille, et que les sons en sont analogues à différens degrés de gravité./

One can still play

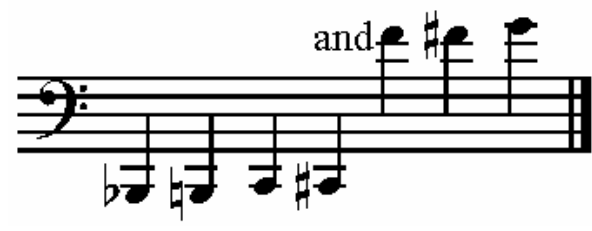

to tune; thus one should abstain from using them.

but it is painful, because these notes are very difficult

There is also a bassoon quarte, which is a fourth lower than the ordinary bassoon, and another bassoon that is, however, rarer; it is called a tenor bassoon (in Italian: fagottino). It is a fifth higher than the ordinary bassoon.

As for its use, all these types of bassoons resemble the ordinary bassoon; they only differ by their pitch. One never uses them in the orchestra, and they only rarely found in German military music.

It should be observed that the oboe, the cor anglais (the English horn), the bassoon and the double bassoon form only one family, and that their sounds are analogous at different degrees of pitch level.

${ }^{118}$ Les sons de la clarinette se divisent en trois classes savoir;

$1 .^{\circ} \quad$ Les plus élevés, sons aigus, difficiles à adoucir et qui s'étendent du Ré

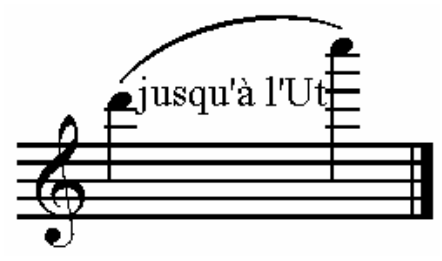

2. $\quad$ Les sons de clairon ou clarinette, sons sonores et brillans qui s'étendent du

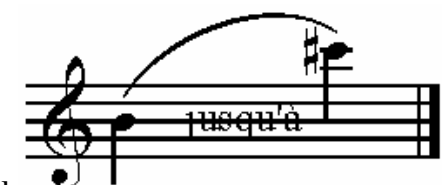


3. ${ }^{\circ}$ Et enfin les sons du chalumeau

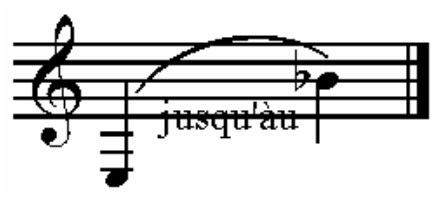
briser les accords, et qui ont quelque chose de ronflant qui ressemble au chalumeau Ordinairement, au dessus d'un passage qui doit être joué une octave plus bas, on écrit le mot chalumeau pour éviter les notes barrées au dessous des lignes.

L'obligation ou est chaque artiste d'avoir plusieurs clarinettes, ce qui est inutile pour le hautbois et la flûte, est bien une espèce d'imperfection; mais d'une antre part, sur la clarinette, on a l'avantage de jouer purement dans tous les tons, ce qui devient difficile pour les autres instrumens; un second avantage c'est que les timbres de chaque espèce de clarinettes diffèrent entr'eux; car la clarinette en La a un son moelleux, la clarinette en Si bémol un son doux, la clarinette en Ut un son dur et aigu, et les petites clarinettes en Ré, Mi bémol et Fa un son tranchant; aussi, ces trois dernières espèces ne servent-elles jamais dans l'orchestre, mais seulement dans la musique militaire.

Sur les nouvelles clarinettes qui sont munies do beaucoup de clefs on peut jouer presque dans tous les tons et cela sans aucune difficulté./

The notes of the clarinet are divided into three classes, namely:

1. The most elevated high notes are difficult to play softly; their range begins at D:

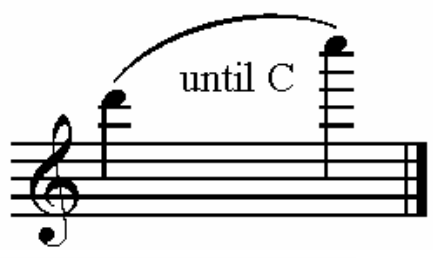

2. The clarion or clarinet notes are sonorous and brilliant; their range begins at
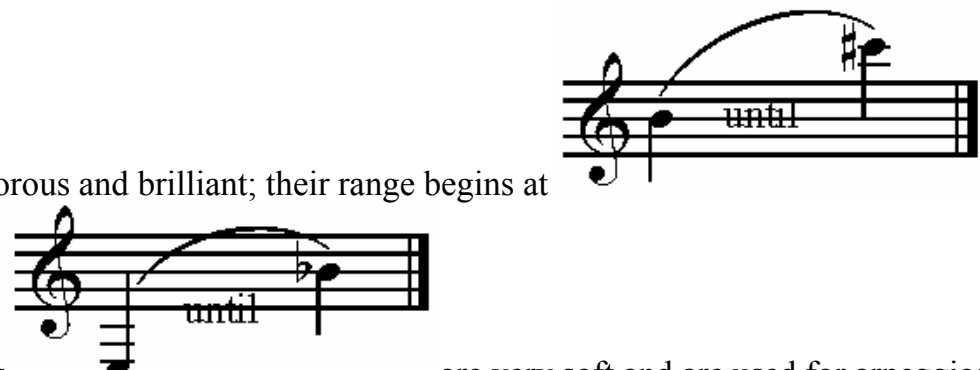

3. And finally the chalumeau: Its notes

are very soft and are used for arpeggios; they have something of a bombastic sound that resembles the chalumeau. Ordinarily, one writes the word chalumeau above a passage that must be played an octave lower, in order to avoid crossed-out notes below the lines.

The obligation is on each musician to own several clarinets, which however is not required for the oboe or the flute. On the clarinet, one has the advantage of producing pure sounds in all keys, which is difficult for other instruments; a second advantage is that the timbre differs from one type of clarinet to another; for the clarinet in A has a mellow sound; the clarinet in B flat a soft sound; the clarinet in C a hard, high sound; and the small clarinets in D, E flat and F a cutting sound; in addition these last three types are never used in the orchestra, only in military music

On the new, many-keyed clarinets, one can play in almost any key without any difficulty whatsoever.

${ }^{119}$ On a aussi maintenant une clarinette basse en $S i$ qui est d'une octave plus basse que la clarinette ordinaire en Sib.

Mr. Meyerbeer s'en est servi, pour la première fois dans son Opéra les Huguenots. Cet instrument ne cause pas beaucoup de fatigue, il est même plus facile et plus doux à jouer que la clarinette ordinaire, le doigté en est le même; il faut seulement avoir des anches un peu ouvertes, faibles, et serrer les doigts, vu qu'il y a des clefs sur lesquelles il faut appuyer pour les boucher; il y avait des clarinettes basses antérieures à cette invention qui étaient en $U t$. 
Il y a encore une clarinette alto qui est une octave plus basse que la petite clarinette en $F a$, et qui, employée dans la musique d'harmonie, pourrait y jouer un grand rôle. Cet instrument dérive probablement du cor de bassette./

There is now also a bass clarinet in $\mathrm{B} b$, which is an octave lower than the ordinary clarinet in $\mathrm{B} b \mathrm{~b}$.

Mr. Meyerbeer used it for the first time in his opera The Huguenots. This instrument is not overly fatiguing, it is even easier and softer to play than the ordinary clarinet, and the fingerings of both instruments are the same. One must merely widen and weaken the reed somewhat, and to tighten the fingers, since there are keys which close by being pressed; there were low clarinets in $\mathrm{C}$ before this invention.

There is still an alto clarinet that is an octave lower than the small clarinet in F and which could play a large role when used in harmonic music. This instrument is probably derived from the basset horn.

${ }^{120}$ This is Ivan Muller (or Mueller). Kastner treats his first name as if it is a family name, but this is a mistake.

${ }^{121}$ On l'appelle probablement cor de bassette' parceque les sons inférieurs ressemblent beaucoup à ceux du cor; comme, au fond, ce n'est qu'une clarinette agrandie, et, proprement, une clarinette basse qui devrait porter ce nom à cause de l'intonation du doigté, \&a qui ont tout-a-fait semblables à ceux de la clarinette, les artistes de ce dernier instrument, peuvent aussi jouer du cor de bassette.

Il est à regretter que ce bel instrument ne soit pas plus généralement usité MOZART en a reconnu le prix, lorsque, dans son chef-d'œuvre le Réquiem I employé le cor de bassette comme accompagnement au Soprano et à l'Alto et aussi pour des solos.

On faisait aussi des cors de bassette en $\mathrm{Sol}, \mathrm{Mi}$, Mi b et Ré mais, ceux en $\mathrm{Fa}$ sont les plus ordinaires./

This was probably named the basset horn because the low note of this instrument strongly resemble those of the This instrument was probably named the basset horn because its low notes strongly resemble those of the horn, for it is merely a large clarinet, and strictly speaking, a bass clarinet should bear this name, because the intonation and fingerings are extremely similar to those of the clarinet. The artists that can play the clarinet can also play the basset horn.

It is regrettable that such a beautiful instrument is not used more often. Mozart recognized its benefits when he used it in his masterpiece Requiem I.

There are also basset horns in $\mathrm{G}, \mathrm{E}, \mathrm{E} b$, and $\mathrm{D}$, but the one in $\mathrm{F}$ is the most common.

${ }^{122}$ Amand Vanderhagen, Méthode nouvelle et raisonnée pour la clarinette (Paris: n.p., 1785).

Baekofen, Anweisungen zur Klarinette (Leipzig: n.p., 1803).

Ivan Muller, Méthode pour la nouvelle clarinette et clarinette-alto (Paris: n.p., 1825).

${ }^{123} \mathrm{~J}$. Fröhlich, Vollständige theoretische-praktische Musikschule für alle beym Orchester gebräuchliche wichtligere Instrumente (Bonn: n.p., 1810-11).

A. Hardy, Méthode de serpent (Paris: n.p., c1810).

Imbert de Sens, Nouvelle méthode de plain-chant (Paris: n.p., 1780).

J.B. Métoyen, Méthode de serpent (MS, c1810).

Abbé L. Nicolas Roze, Méthode de serpent (Paris: n.p., 1814). 
${ }^{124}$ L'étendue générale du cor à partir du corps de rechange $S i$ b grave, jusqu'a celui de $S i b$ aigu, comparé à un

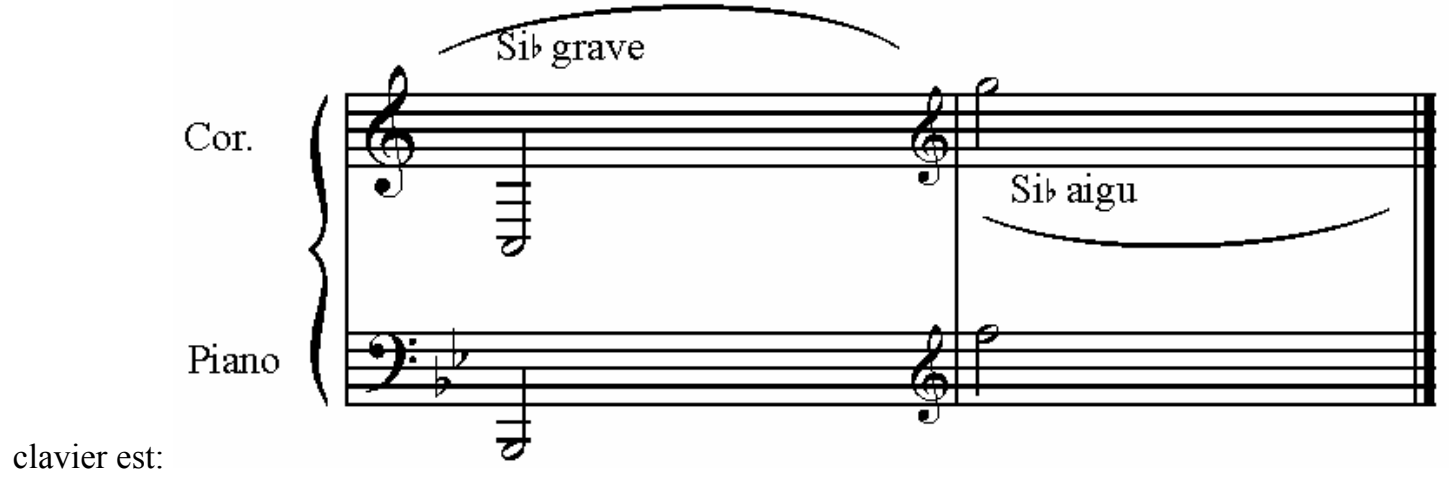

On voit, que la clef de $S o l$ du cor n'indique pas le diapason véritable et ôte même à la note le nom qui lui appartient; cette note doit se lire sur la clef d'Ut, 4. ${ }^{\mathrm{e}}$ ligne, représentée par le corps de rechange $\mathrm{Si}$. ./

The general range of the horn, starting from the crook in low $\mathrm{B} b$ to the crook in high $\mathrm{B} b$, compared to the piano, is:

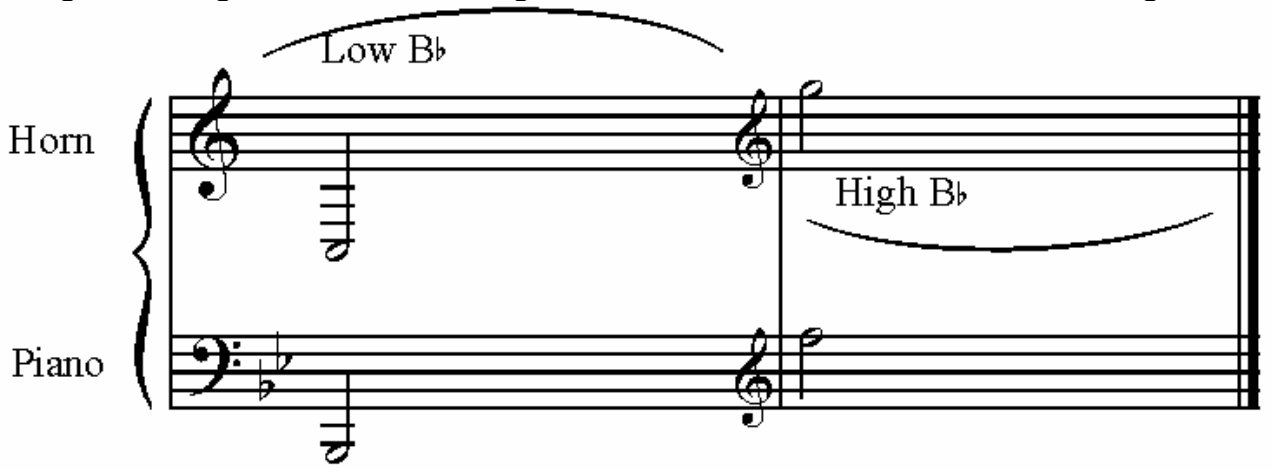

One sees, that the

horn's treble clef does not indicate its true tuning, and even takes the name belonging to it; this note must be read on the $\mathrm{C}$ clef fourth line, represented by the $\mathrm{B} b$ crook.

${ }^{125}$ La connaissance ou diapason des corps de rechange est une chose de la plus haute importance quand on double une partie chantante; les violons font ensemble plusieurs quartes nécessaires, mais le cor doublant la $1 .{ }^{\text {re }}$ partie 


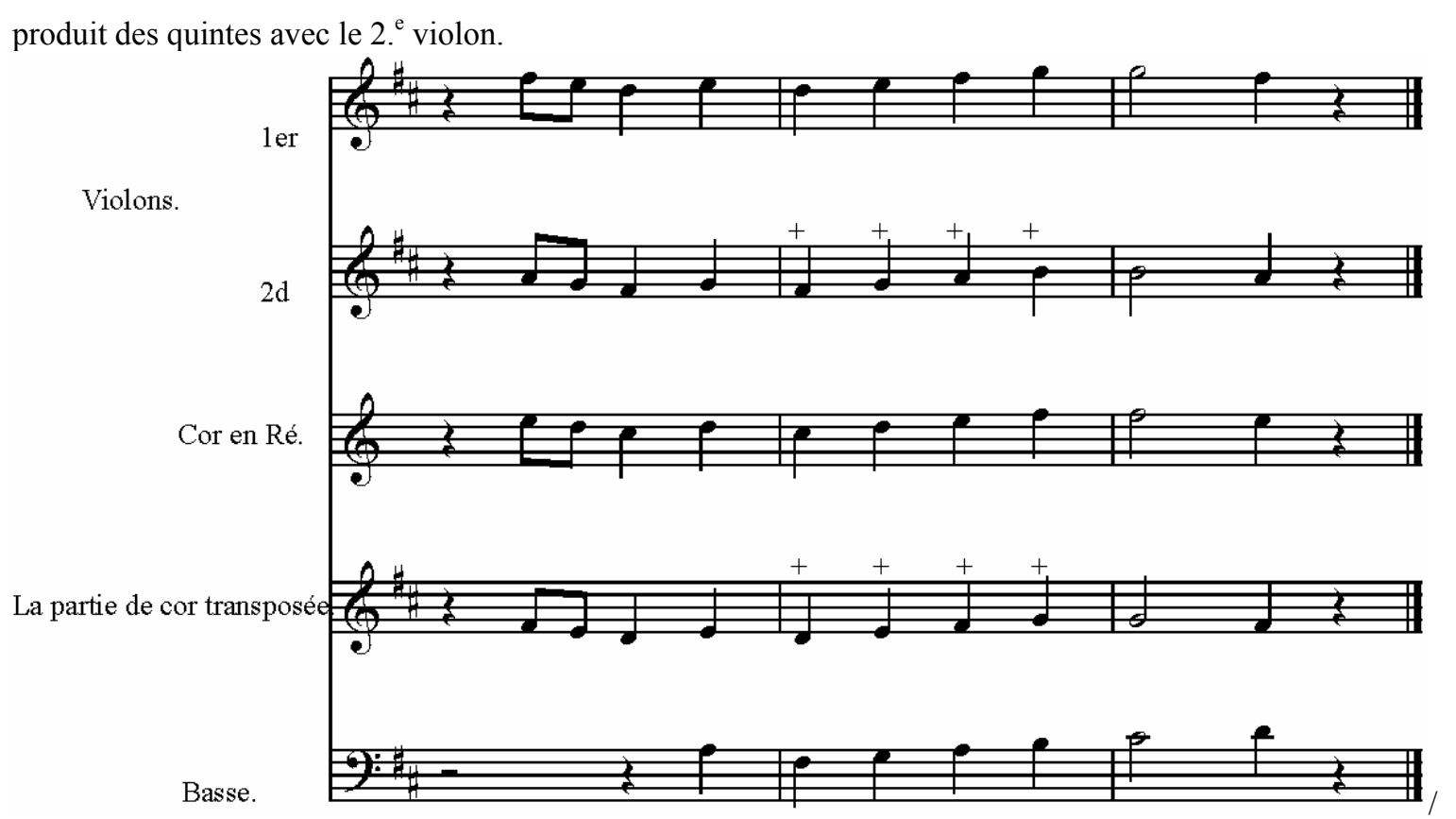

The knowledge or tuning of the crooks is of the highest importance when a singing part is doubled; the violins form several necessary fourths, but the horn doubling the first part produces fifths with the second violins.

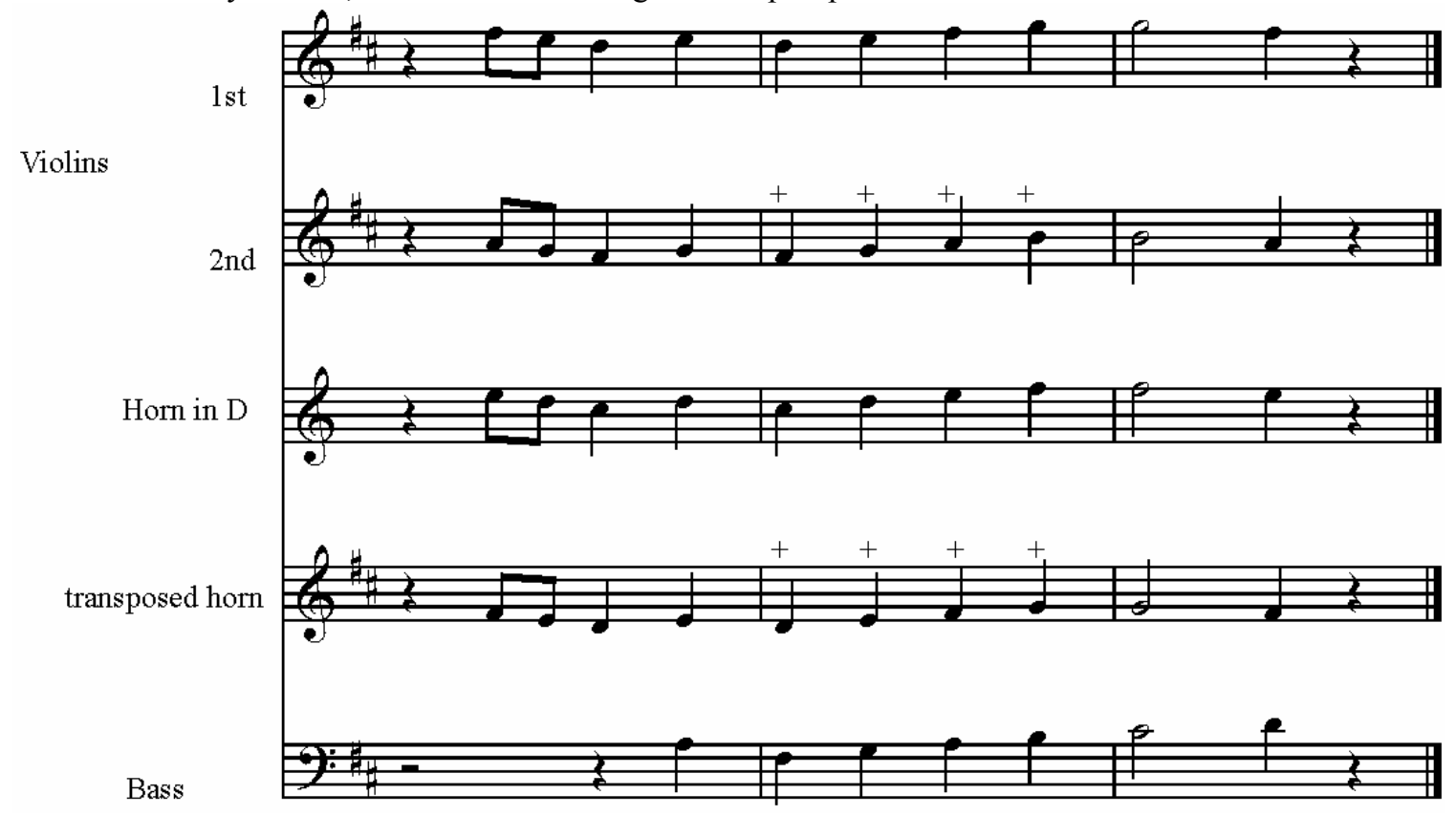

${ }^{126}$ Dans la musique funèbre, on emploie très souvent la sourdine, tant pour le cor que pour la trompette. Le mot porte avec lui sa signification et na pas besoin d'explication ultérieure, on doit surlement observer qu'il faut l'indiquer dans la partition et la partie détachée; par exemple: corni con sordini, cors avec sourdines; ou bien trompettes avec sourdines./ 
In funeral music one uses the mute as often for the horn as for the trumpet. The word implies its own meaning and requires no further explanation; however one must indicate it in the score and the individual part; for example: corni con sordini, cors avec sourdines; or trompettes avec sourdines.

${ }^{127}$ H. Domnich, Méthode de premier et de second cor (Paris: n.p., 1807). L.F. Dauprat, Méthode de cor alto et cor basse (Paris: n.p., 1824).

${ }^{128}$ En France, les cors de chasse sont généralement en Ré, (par exemple dans les chasses Royales,) cependant il y a des amateurs qui par fantaisie, ont adopté des cors de chasse dans d'autres tons.

Le cor omnitonique, cor muni de tons les tons, et nouvellement inventé par Mr. Sax de Bruxelles, doit surpasser par beaucoup d'avantages le cor à pistons; il doit être le meilleur cor d'orchestre, car, malgré tous les tubes qui y sont ajoutés, il n'a cependant rien perdu du ton naturel du cor ordinaire; une recommandation de plus, c'est qu'il est plus facile à transporter que le cor ordinaire.

On entend par cor mixte, un cor de solo entre le premier et le second cor qui s'emploie très rarement; il n'a ni les sons les plus graves de l'un ni les plus élevés de l'autre; c'est en quelque sorte une espèce de cor baryton, et pour cette raison, très facile à jouer mais pour exécuter la partie de cor mixte, on se sert ordinairement du cor ordinaire.

Il y a encore une espèce de cors qu'on appelle cors Russes; ils sont droits à peu près comme un porte-voix et ne possèdent chacun qu'un seul ton. Chaque artiste n'a donc sur sa partie que les pauses nécessaires et ce ton qu'il donne lorsque les notes l'exigent; compter les pauses avec exactitude, voilà le point essentiel. Les artistes de cor Russe y ont acquis une telle habileté qu'on serait tenté de croire qu'il n'y a qu'un seul artiste, tandis qu'il ' en a au moins une trentaine pour former un choeur. Ils exécutent des symphonies entières, des concertos, marches, chorals, et en général tout ce qui peut s'exécuter en moyen de plusieurs instrumens. C'est un bohémien nommé Maresch qui a inventé ce genre de musique et l'a introduit en 1754 Petersbourg, sur la demande du grand Venenr Noryschkin./

In France, the hunting horns are generally in D (as in royal hunting, for example); however there are amateurs who imaginatively adopted hunting horns in other keys.

The omnitonic horn, equipped with all the tones and newly invented by Mr. Sax of Brussels, must surpass by far the many advantages of the valve horn. It must be the best horn for orchestra, for, despite all the tubes which have been to it, it did not lose any of the ordinary horn's natural tone. Moreover, it is easier to transport than the ordinary horn.

By "mixed horn", one understands this as a solo horn between the first and second horn (which plays only very seldom); it has neither the lowest sounds of one nor the highest of the other; it is to some extent a type of baritone horn, and for this reason, very easy to play. But in order to perform the mixed horn's part, one usually uses the ordinary horn.

There is another type of horn called the Russian horn; it is shaped like a megaphone and has only one tone. Thus each artist has only the necessary pauses on his part, and the key to be played when the notes so require. The essential point here is to count the pauses very precisely. The musicians who play the Russian horn have acquired such skill there that one would be tempted to believe that only one musician is playing, but there are at least about thirty that form a chorus. They perform entire symphonies, concertos, marches, chorals-in general, everything that can be performed on several instruments. A gypsy named Maresch invented this type of music and introduced it in St. Petersburg in 1754, on the request of the great Venenr Noryschkin.

${ }^{129}$ Pour la fanfare, on se sert ordinairement de quatre trompettes qui sont accordées à volonté dans différens tons; on les nomme alors: $1 .^{\mathrm{e}}$ trompette (clarino $1 .^{\circ}$ ) $2 .^{\mathrm{e}}$ trompette (clarino $2 .^{\circ}$ ) $3 .^{\mathrm{e}}$ trompette (principale) et $4 .^{\mathrm{e}}$ trompette (toccato). Les premières ont un chant très léger, le plus souvent en tierces à partir de $l^{\prime} U t$ de la $3 .^{\mathrm{e}}$ petite octave, jusqu'à l' $U t$ de la $4 .^{\mathrm{e}}$ petite octave./

Four trumpets, all tuned to different keys as desired, are usually used for brass band; they are named: first trumpet (first clarino) second trumpet (second clarino) third trumpet (principale) and fourth trumpet (toccato). The first have a very light song, generally in thirds starting at $\mathrm{C}$ of the third small octave, to $\mathrm{C}$ of the fourth small octave. 
${ }^{130}$ On fait ordinairement la cadence sur la quinte $R e ́$, Sol on ensuite $U t, M i$; si le morceau module de $U t$ en $F a$, on leur donne la quinte doublée $U t, U t$; si le morceau module en $L a$ mineur, on leur donne la quinte doublée $M i$, $M i$; la troisième trompette (principale) n'a le plus souvent que les deux notes $U t$ ou Sol, entre les cinq lignes de la portée, lorsque la première et la seconde sont plus hautes. La quatrième trompette (toccato) a ordinairement l'Ut et le $S o l$ graves sons les cinq lignes de la portée et marche alors avec les timballes à l'octave.

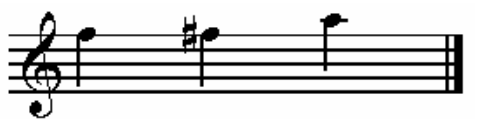

Il faut se garder de donner les notes:

aux premières trompettes comme notes pas d'une intonation facile et pure./

One usually writes the cadence on the fifth, $\mathrm{D} / \mathrm{G}$ to $\mathrm{C} / \mathrm{E}$. If the piece modulates from $\mathrm{C}$ to $\mathrm{F}$ they are given the doubled fifth $\mathrm{C} / \mathrm{C}$; if the piece modulates in A minor, they are given the doubled fifth $\mathrm{E} / \mathrm{E}$ and the third trumpet (principale) generally only plays the notes $\mathrm{C}$ or $\mathrm{G}$ between the five lines of the staff, when the first and the second are higher. The fourth trumpet (toccato) usually plays low $\mathrm{C}$ and $\mathrm{G}$ between the five lines of the staff, and then plays with the timpani an octave lower.

It is necessary to take care not to play the following notes:

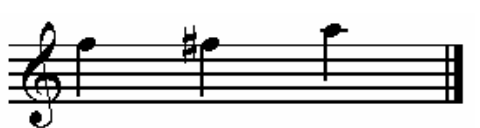
as entrances, but always only as momentary notes, because, (as we have already said) they do not have good intonation.

${ }^{131}$ J.E. Altenburg, Versuch einer Anleitung zur heroisch-musikalischen Trumpeter- und Pauker-Kunst (Halle:n.p., 1795).

Joseph David Buhl, Méthode de trompette (Paris: n.p., 1825).

Henri Adrien Louis Kling, Populäre instrumentationslehre, oder die kunst des instrumentierens mit genauer beschreibung der eigentümlichkeiten aller instrumente, nebst einer anleitung zum dirigieren (Hannover: Oertel, 1888).

${ }^{132}$ On peut accorder le cornet plus bas que $\mathrm{Lab}$, c'est-à-dire en $\mathrm{Sol}$, Fa, et même encore plus bas, mais on ne doit pas généralement dépasser l'accord de Sol, parceque le son n'est plus un son de cornet mais bien de trompette, et que les tons deviennent sourds à cause du rétrécissement des tubes. On a des cornets en Sol qui ne s'emploient ordinairement que dans ce ton; en Allemagne surtout, presque tous les postillons sont munis d'un cornet en Sol. Les cornets en $U t$ sont les meilleurs, parcequ'on peut les accorder dans presque tous les tons avantage qui n'existe pas pour ceux en Sib ou en Sol./

One can play the cornet lower than A b, i.e. in G, F and even lower, but one should not generally exceed the chord of $\mathrm{G}$ because the sound is no longer that of the cornet but of the trumpet, and the keys become mute because of the contracting of the tubes. There are cornets in G that usually play only in this key-especially in Germany; almost all the pitches are provided with a cornet in $\mathrm{G}$. The cornets in $\mathrm{C}$ are the best, because one can tune them in almost all the keys which do not exist for cornets in B b or in G.

${ }^{133}$ On avait jadis une trompette nommée trompette à coulisses, qu'on peut regarder comme le soprano des trombonnes et qui a tous les tons et demi-tons de la gamme, mais elle me sert plus beaucoup depuis l'invention de la trompette à pistons qui lui est bien préférable.

L'effet général des pistons est de baisser à volonté d'un demi-ton d'un ton, et d'un ton et demi, (comme nous l'avons d'ailleurs déjà dit à l'article du cor,) le diapason de toute l'étendue du ton ou corps de rechange placé sur l'instrument; leur effet particulier est de permettre à l'exécutant d'emprunter la tonique et les harmoniques des tons qui n'existaient pas sur l'instrument avant cette invention: Exemple:

sans pistons

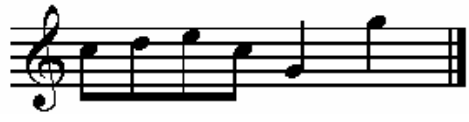

avec le ler piston

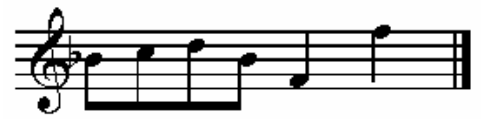


avec le $2^{e}$ piston

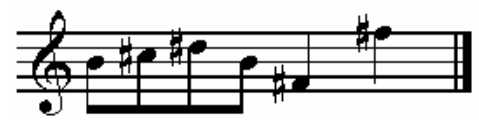

avec les deux pistons

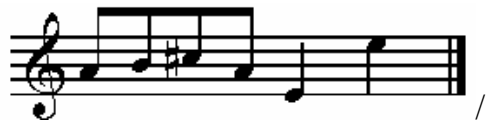

There was formerly a trumpet called the slide trumpet, which is treated like the soprano trombone and which can play all the notes of the range, but its use has declined since the invention of the valve trumpet, which is definitely preferable to the slide trumpet.

The general effect of the valves is to lower the sound a semi-tone, a tone, and a tone and a half as desired (as stated in the article on horn); the tuning of the entire range of the keys or crooks used on the instrument; their particular effect is to permit the performance of the tonic and harmonics which did not previously exist on this instrument. For example:

without valves

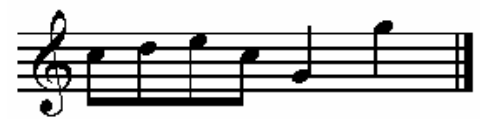

with first valve

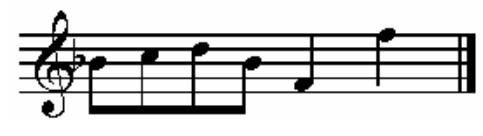

with second valve

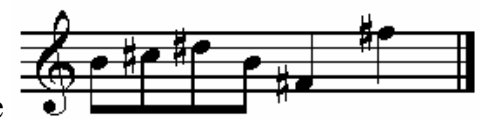

with both valves

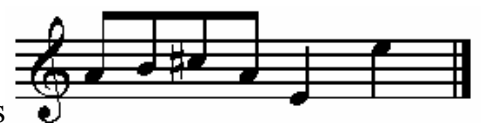

${ }^{134}$ Les corps de rechange qui appartiennent exclusivement au cornet à pistons sont: $L a, L a$, Sib aigu; les autres corps de rechange Sol. Fa, Mi, Mib, Ré se trouvent juste à l'unisson de la trompette./

The crooks which are belong exclusivly to the valved cornet are high A b, A, and B b, the other crooks G, F, E, E b, and $\mathrm{D}$ are found in unison with the trumpet.

${ }^{135}$ En général on se sert des trompettes à clefs de la même manière que des diffi....

In general the keyed trumpets are used in the same manner as the

${ }^{136}$ Quelques compositeurs écrivent le trombonne alto, sur la clef de Sol, 2. ${ }^{\mathrm{e}}$ ligne, d'autres sur la clef de $F a$, 4 . $^{\mathrm{e}}$ ligne.

Tout le monde sait que les trombonnes sont munis d'une coulisse qui peut se tirer de 6 à 7 degrés différens; chacun de ces degrés comprend 5, 6, et même jusqu'à 7 tons.

Le trombonne alto, par exemple, a les degrés suivans qui sont tons généralement usités.

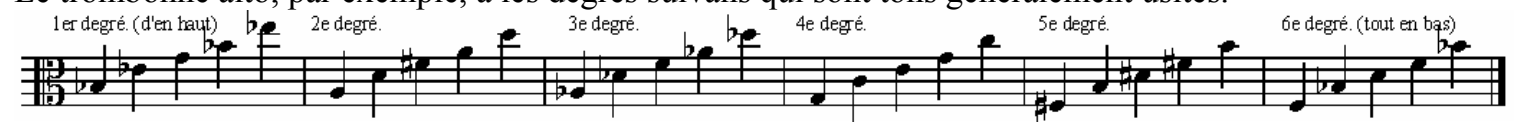

Quelques artistes donnent encore des tons plus hauts et plus graves, mais on ne doit pas s'en servir, parceque, d'ordinaire, l'exécutant ne serait pas à même de les donner; (ceci s'applique également sux trombonnes ténor et basse.)

Le trombonne ténor a les degrés suivans

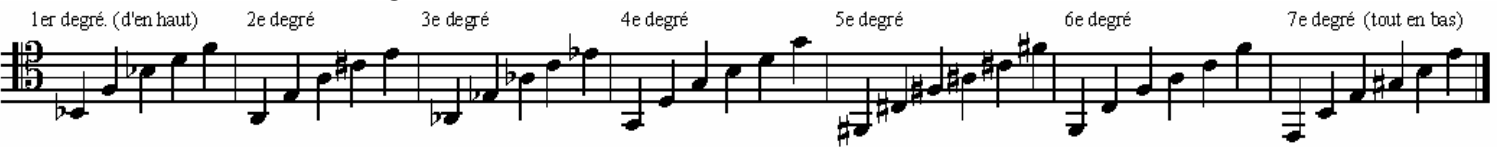

Les tons les plus graves du trombonne ténor ne sont pas employés lorsque les trois trombonnes sont réunis. 
Le trombonne basse a les degrés suivans:

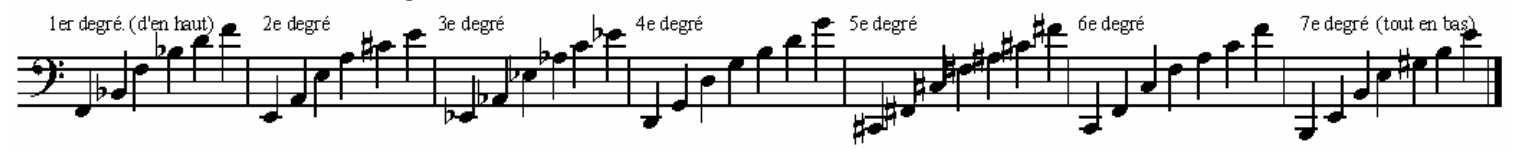

On doit traiter les tons les plus graves avec précaution, parcequ'ils sont difficiles à intonner, et d'ailleurs, comme dans la plupart des orchestres on n'a pas de trombonne basse et que le trombonne ténor est obligé de le remplacer, il vaut mieux ne pas composer plus bas que $M i$ de la grande octave:

On avait antrefois, (surtout en Allemagne) pour accompagner daus les chorals les voix humaines au même diapason, quatre espèces de trombonnes savoir: $1 .^{\circ}$ discant, $2 .^{\circ}$ alto, $3 .^{\circ}$ ténor, $4 .^{\circ}$ basse.

Le trombonne discant était assex rare, mais on employait fréquemment deux espèces de trombonnes basses, dont l'un se nommait trombonne quarte et l'autre trombonne quinte.

1. ${ }^{\circ}$ L'étendue des trombonnes discant et alto était:

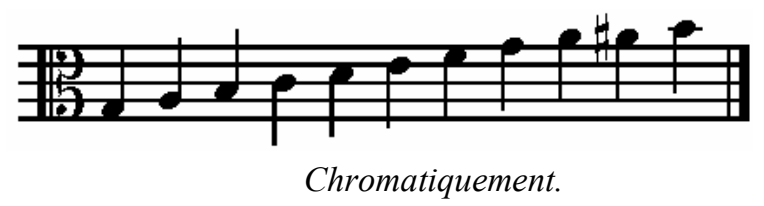

2. ${ }^{\circ}$ L'étendue du trombonne ténor était:

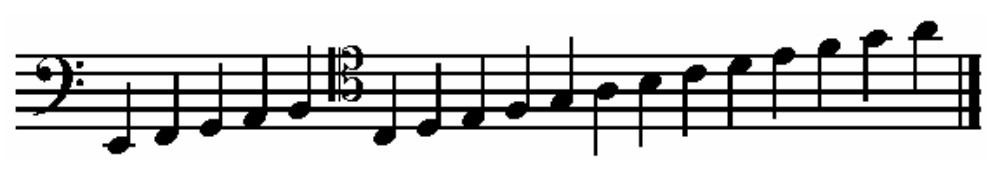

Chromatiquement.

3. ${ }^{\circ}$ L'étendue du trombonne quarte était:
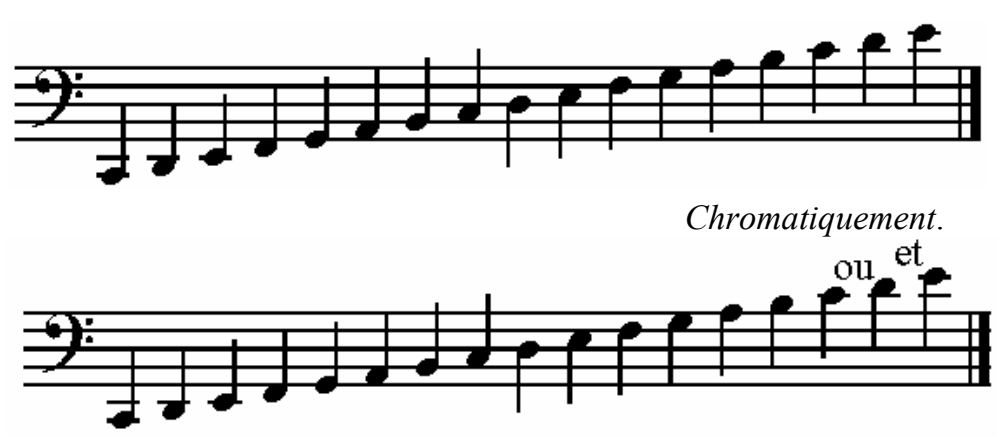

4. ${ }^{\circ}$ L'étendue du trombonne quinte était:

Chromatiquement.

Plus tard, on se servit à la place du trombonne discant d'un instrument appelé cornette, cornetto, en Allemand zinké son étendue allait du La de la petite octave, jusqu'à l'Ut de la 4. e petite octave, chromatiquement. On l'écrivait sur la clef d'Ut, 1. re ligne, et on s'en servait pour soutenir le soprano dans les Eglises. Il y avait encore de ce genre un autre instrument plus petit nommé cornettino (zinké quarte), qui était d'une octave plus haut que le premier ainsi, son étendue allait du Re de la 2. ${ }^{\mathrm{e}}$ petite octave jusqu'au Fa de la 4. ${ }^{\mathrm{e}}$ petite octave.

Quoique cet instrument soit en bois, j'ai cru devoir en placer ici la description parcequ'on l'emplovait toujours avec accompagnement de trombonnes. On a une Méthode pour cet instrument de Buhl./

Some composers write for the alto trombone on the treble clef, others on the bass clef.

Everyone knows that the trombones are provided with a slide which can draw from 6 to 7 different degrees; each one of these degrees includes five, six, and even up to seven notes. 


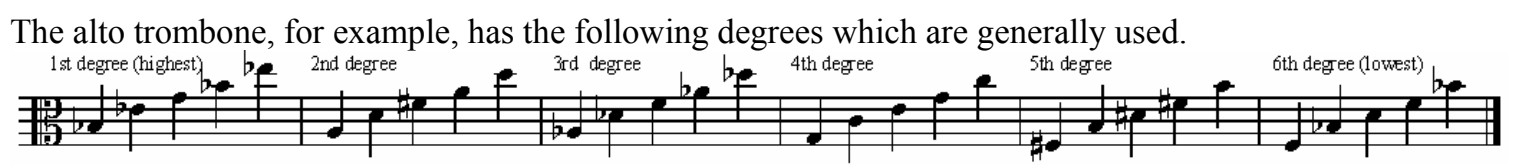

Some artists still play higher and lower notes, but one should not use these, because, it would not normally be possible to play them (this also applies to tenor and bass trombones).

The tenor trombone has the following degrees:

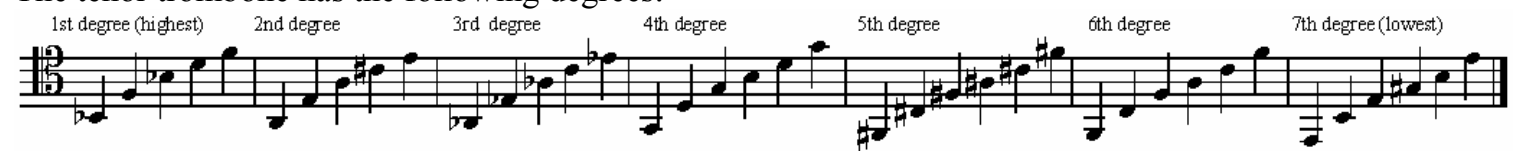

The lowest notes of the tenor trombone are not used when the three trombones play together.

The bass trombone has the following degrees:

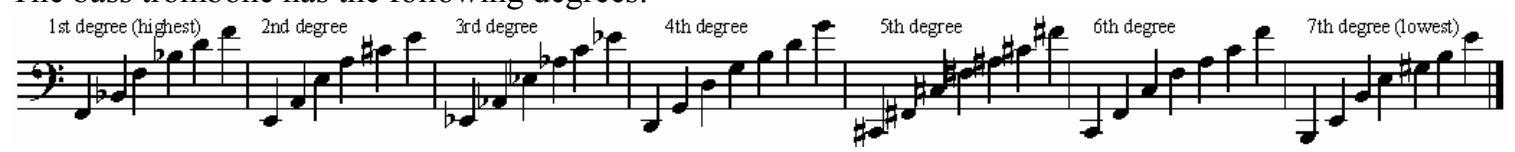

One must treat the lowest notes cautiously, because they are difficult to tune, and moreover, since there is no bass trombone in the majority of orchestras and the tenor trombone is obliged to replace it, it is better to compose no lower than $\mathrm{E}$ of the great octave:

Formerly (especially in Germany), there were four types of trombones which accompanied vocal chorales of the same tuning, namely: 1. discant, 2. alto, 3. tenor, 4. bass.

The discant trombone was rather rare, but two low types of trombones were frequently employed, one of which one was named fourth trombone and the other, fifth trombone.

1. The range of the discant and alto trombones and was:

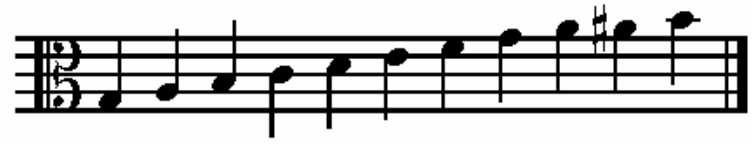

Chromatically.

2. The range of the tenor trombone was:

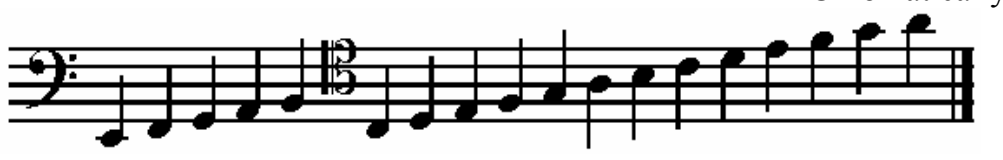

Chromatically

3. The range of the fourth trombone was:

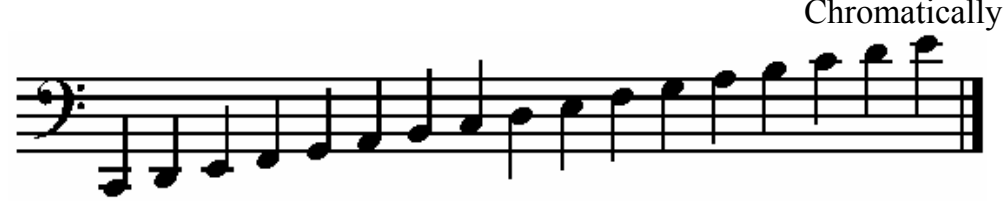

Chromatically

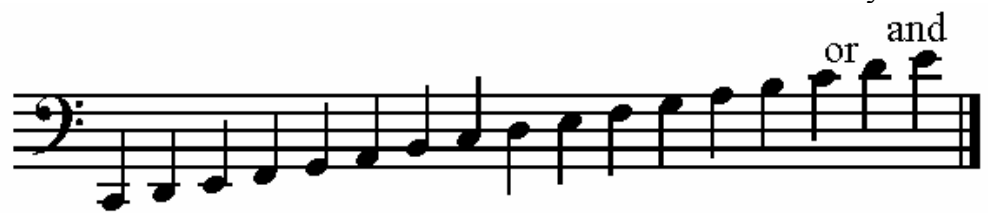

4. The range of the fifth trombone was:

Chromatically

Later, the discant trombone was replaced by an instrument called cornet, cornetto, or in German, zinké. Its range began at $\mathrm{A}$ of the small octave, and ended at $\mathrm{C}$ of the fourth small octave, chromatically. One wrote it on the $\mathrm{C}$ clef, first line, and one used it to support the soprano in the churches. There was another smaller version of this 
instrument named the cornettino (zinké quatre), which was an octave higher than the first. Thus, its range began at $\mathrm{D}$ of the second small octave and ended at $\mathrm{F}$ of the fourth small octave.

Though this instrument is made out of wood, I believed it necessary to include its description here, because one always uses it with trombone accompaniment. There is a method for this instrument by Buhl.

${ }^{137}$ A. Braun, Gamme et méthode pour les trombonnes alto, tenor et basse (Paris: n.p., c1795).

V. Cornette, Méthode pour trombone: alto, ténor et basse, contenant des gammes pour les différents trombones, des leçons, études, doux et trios (Paris: Costallat, 1900).

${ }^{138}$ On fait aussi maintenant des trombonnes alto à pistons qui ont la même étendue que le trombonne alto ordinaire et qui l'emportent sur ce dernier par les mêmes avantages./

Alto valved trombones are also made; they have the same range as ordinary alto trombones, which overpower the latter with the same advantages.

${ }^{139}$ Dans le principe on fabriquait des ophicléides en bois, mais le ton n'en était pas à beaucoup près aussi fort que celui de nos ophicléides actuels en cuivre./

In the beginning, ophicleides were made of wood, but the sound was not as loud as are our present-day copper ophicleides.

${ }^{140}$ Le bombardon était un instrument à vent qui servait autrefois de basse pour le chalumeau et le hautbois; son nom vient de (bombare, bourdonner.)

Il y en avait de plusieurs espèces: Le grand bombardon qui avait 10 pieds un pouce de longueur. Le bombardon ténor muni dans le principe d'une seule clef et qui plus tard en a porté le nombre jusqu'à quatre: il descendait jusqu'à l'Ut de la grande octave, et se nommait aussi Nicolo. Le bombardon alto qui était de la grandeur du chalumeau et s'appelait aussi: petit bombardon ou bombardon Piccolo; ils avaient tous à peu près le même doigté et on les traitent de la même manière. Cet instrument était en bois (comme d'abord l'ophicléide) puis, il s'améliora, changea de forme, remplaça le bois par le cuivre, s'enrichit peu à peu de beaucoup de clefs, et enfin remplaça ces clefs par trois pistons qui sont infiniment plus avantageux pour l'artiste, et ne font pas le bruit désagréable produit par les clefs de l'ophicléide, surtout dans les passages rapides./

The tuba was a wind instrument, which, formerly, served as the bass for the chalumeau and the oboe; its name comes from (bombare, bourdonner).

There were several types of tuba: the large tuba which was 10 feet and one inch in length. The tenor tuba had only one key at first, which later increased to four. It went as low as $\mathrm{C}$ of the great octave, and was also called Nicolo. The alto tuba, which was the same size as the chalumeau, was also called "small tuba" or bombardon piccolo; they all had about the same fingerings and are treated in the same manner. This instrument was made out of wood (as was the ophicleide, initially) then it was improved upon; it changed its shape, the wood was replaced with copper, and little by little many keys were added. Finally, these keys were replaced by three pistons, which are infinitely more advantageous for the artist and do not make the unpleasant noise that is produced by the keys of the ophicleide, especially in the fast passages.

${ }^{141}$ On a inventé en Hollande une nouvelle espèce de timballes, qui ont la forme ordinaire à l'extérieur. Dans le fond passe une vis fixée par l'extrémité inférieure à l'espèce de chevalet qui sert de support à l'instrument; cette vis pénètre dans le corps de la timballe par un écrou auquel aboutissent quatre petites barres de fer supportant un cercle du même métal qui fait le tour intérieur de la machine contre la paroi. La peau se tend sur la caisse au moyen d'une vis comme pour les timballes ordinaires; cette peau tendue est en contact avec le cercle de fer, de sorte qu'on n'a qu'à tourner l'appareil de droite à gauche pour que ce cercle en s'élevant presse la peau, la fasse tendre davantage et monte ainsi le diapason de l'instrument; tandis qu'on le baisse en détendant la peau, et en tournant la machine en sens inverse. Ce procédé si simple a cet avantage que l'artiste un peu exercé n'a qu'à donner une petite impulsion de droite à gauche on de gauche à droite, pour monter ou descendre au ton requis en moins d'une seconde et sans 
occasionner le cliquetis toujours désagréable des clefs; il faut encore joindre à cela la grande justesse qu'on obtient dans les tons. Il serait à désirer qu'on introduisit ce genre de timballes dans nos orchestres on elles seraient d'une grande utilité pour les compositeurs et d'une grande commodité pour les artistes.

(Note comminiquée par Mr. M. Retemeier)

Mr. Eiglinger vient aujourd'hui d'inventer en Allemagne une nouvelle timballe qui paraît offrir de grands avantages aux compositeurs, car, avec deux timballes, et dans le mouvement assez rapide de $=50$ du Métr de Mael: on peut exécuter des passages semblables à celui-ci.

Ces timballes ne sont pas d'un volume plus considérable que les autres; leur sonorité est parfaite. (Gazette musicale No. $45,3^{\mathrm{e}}$ année)./

A new kind of timpani, which retained its ordinary exterior shape, was invented in Holland. On the inside, a screw is affixed at the lower end to a type of bridge that is used as a support for the instrument. The body of the timpani is penetrated by a nut fitted with four small iron bars that support a circle of the same metal; encircles the interior of the mechanism, against the wall. The skin is tightened over the drum by means of a screw as with the ordinary timpani; this taut skin is in contact with the iron circle, so that one has only to turn the apparatus located on the right-hand side toward the left so that, in rising, this circle presses the skin, causing it to tighten, and thus acts as a tuning device for the instrument. One lowers it by slackening the skin and turning the mechanism in the opposite direction. This very simple process has the advantage that the artist need only give a small turn from right to left or from left to the right, to go up or down to the necessary key in less than one second and without causing the always unpleasant rattling of the keys; it is necessary to add to this the great accuracy which one obtains in the key. It would be desirable to introduce this type of timpani into our orchestras; they would be very useful for the composers, and a great convenience to the artists.

(Note communicated by Mr. Retemeier)

In Germany, Mr. Eiglinger has just invented a new timpani which appears to offer composers great advantages, because with two timpani, and in the rather fast movement from $M M=50$, one can perform passages similar to this one.

These timpani are not significantly louder than the others; their sonority is perfect. (Gazette musical No 45, third annual). 


\section{LIST OF REFERENCES}

Bartenstein, Hans. “Die frühen Instrumetationslehren bis zu Berlioz.” Archiv für Musikwissenschaft, 28 (1971): 98118.

Bent, Ian D. and Anthony Pople. “Analysis.” In The New Grove Dictionary of Music Online, ed. L. Macym (Accessed 24 January 2003), <http://www.grovemusic.com>.

Brook, Barry S., Richard Viano, and Albert R. Rice. "Roeser, Valentin.” In The New Grove Dictionary of Music Online, ed. L. Macy, (Accessed 24 January 2003), <http://www.grovemusic.com>.

Brown, Howard Mayer and Stanley Sadie, eds. Performance Practice: Music before 1600. New York: Norton, 1990.

Buelow, George. "Mattheson, Johann." In The New Grove Dictionary of Music Online, ed. L. Macy, (Accessed 24 January 2003), <http://www.grovemusic.com>.

Bullard, Beth. "Virdung, Sebastian," In The New Grove Dictionary of Music Online, ed. L. Macy, (Accessed 24 January 2003), <http://www.grovemusic.com>.

Carse, Adam. "Text-books on orchestration before Berlioz." Music and Letters, 22 (1941): 26-31.

Castil-Blaze, François. "Revue critique. Romances de Georges Kastner." La Revue et Gazette musicale, (24 January 1841): 53-54.

Citron, Pierre, ed. Hector Berlioz: Correspondance générale. Vol. 5, 1855-1859. Paris: Flammarion, 1989.

Farmer, H G and Raoul Camus. "Bandmasters." In The New Grove Dictionary of Music Online, ed. L. Macy, (Accessed 23 January 2002), <http://www.grovemusic.com>

Fétis, François-Joseph. "Kastner, Jean-Georges." In Biographie Universelle des Musiciens et Bibliographie Générale de la Musique, 2nd edn. (Paris: Libraireie de Frimin Didot Frères, 1866), 480.

Kastner, Jean-Georges arr. Sigurd Rascher. Sextour. Oswego, New York: Ethos, 1982.

Kastner, Jean-Georges. Manuel Général de Musique Militaire a l'Usage des Armées Françaises, Comprenant: $1^{\circ}$ l'Esquisse d'une Histoire de la Musique Militaire chez les Différents Peuples, Depuis l'Antiquité Jusqu'à Nos Jours; $2^{\circ}$ la Nouvelle Organisation Instrumentale Prescrite par l'Ordonnance Ministérielle du 12 Aô̂t 1845; $3^{\circ}$ la Figure et la Description des Instruments qui la Composent, M. Adolphe Sax; $4^{\circ}$ Quelques Instructions sur la Composition et l'Exécution de la Musique Militaire. Paris: Firmin Didot Frères, 1848.

Kastner, Jean-Georges. Traité général d'Instrumentation. Paris: n.v., 1837.

La May, Thomasin and Stewart A. Carter, "Kastner, Jean-Georges," The New Grove Dictionary of Music Online, ed. L. Macy (Accessed 23 January 2002), <http://www.grovemusic.com>.

La Revue et Gazette musicale, (22 December 1867): 408.

“Les Danses des Morts.” La Revue et Gazette musicale, (2 May 1852): 141-142.

Loewenberg, Alfred. “Kastner, Jean Georges.” In Grove's Dictionary of Music and Musicians, ed. Charles Grove, London: MacMillan, 1954.

Ludwig, Hermann. Johann Georg Kastner, ein elsässischer Tondichter, Theoretiker und Musikforscher; sein Werden und Wirken. Leipzig: Breitkopf, 1886. 
MacDonald, Hugh. Berlioz's Orchestration Treatise: A Translation and Commentary. Cambridge: Cambridge University Press, 2002.

Mainzer, Joseph. “Traité général d'Instrumentation.” La Revue et Gazette musicale, (17 September 1837): 416-418.

Merritt, Frederic. "La Borde, Jean-Baptiste de." In The New Grove Dictionary of Music Online, ed. L. Macy, (Accessed 24 January 2003), <http://www.grovemusic.com>.

Prout, Ebenezer. Instrumentation. Philadelphia: Diston, $n . d$.

Raumberger, Claus and Karl Ventzke: "Saxophone." In The New Grove Dictionary of Music Online, ed. L. Macy, (Accessed 24 January 2003), <http://www.grovemusic.com>.

Riessauw, Anne-Marie. “Gevaert, François-Auguste.” In The New Grove Dictionary of Music Online, ed. L. Macy, (Accessed 24 January 2003), <http://www.grovemusic.com>.

Williamson, Rosemary. "Prout, Ebenezer.” In The New Grove Dictionary of Music Online, ed. L. Macy, (Accessed 24 January 2003), <http://www.grovemusic.com>. 